UNIVERSIDADE DE SÃO PAULO

FACULDADE DE ECONOMIA, ADMINISTRAÇÃO E CONTABILIDADE DEPARTAMENTO DE ADMINISTRAÇÃO

PROGRAMA DE PÓS-GRADUAÇÃO EM ADMINISTRAÇÃO

A ADOÇÃo DE FERRAMENTAS DE GESTÃO PARA A SUSTENTABILIDADE

E A SUA RELAÇÃO COM OS PRINCÍPIOS ECOLÓGICOS NAS EMPRESAS

Lilian Mara Aligleri

Orientador: Prof. Dr. Isak Kruglianskas

SÃO PAULO 
Prof. Dr. João Grandino Rodas

Reitor da Universidade de São Paulo

Prof. Dr. Reinaldo Guerreiro

Diretor da Faculdade de Economia, Administração e Contabilidade

Prof. Dr. Adalberto Américo Fischmann

Chefe do Departamento de Administração

Prof. Dr. Lindolfo Galvão de Albuquerque

Coordenador do Programa de Pós-Graduação em Administração 


\section{A ADOÇÃO DE FERRAMENTAS DE GESTÃO PARA A SUSTENTABILIDADE E A SUA RELAÇÃO COM OS PRINCÍPIOS ECOLÓGICOS NAS EMPRESAS}

Tese apresentada ao Departamento de Administração da Faculdade de Economia, Administração e Contabilidade da Universidade de São Paulo como um dos requisitos para a obtenção do título de Doutor em Administração.

Orientador: Prof. Dr. Isak Kruglianskas

\section{SÃO PAULO}




\section{Aligleri, Lilian Mara}

A adoção de ferramentas de gestão para a sustentabilidade e a sua relação com os princípios ecológicos nas empresas / Lilian Mara Aligleri São Paulo, 2011.

$170 \mathrm{p}$.

Tese (Doutorado) - Universidade de São Paulo, 2011.

Orientador: Isak Kruglianskas.

1. Desenvolvimento sustentável 2. Administração de empresas Aspectos ambientais 3. Empresas - Aspectos ambientais 4. Sustentabilidade I. Universidade de São Paulo. Faculdade de Economia, Administração e Contabilidade II. Título. 


\section{AGRADECIMENTOS}

Nesses quatro anos de curso de doutorado fui uma viajante. As viagens que fiz da cidade de Londrina $^{1}$ a São Paulo aproximaram-se de $80.700 \mathrm{~km}$, o suficiente para dar duas voltas no Planeta Terra, considerando a circunferência da linha do Equador ${ }^{2}$.

O longo caminho percorrido e os inúmeros ir e vir só foram possíveis porque muitas pessoas partilharam comigo esta prazerosa caminhada e entre elas algumas especiais. Dessa forma, gostaria de registrar meu agradecimento:

- Ao Prof. Dr. Isak Kruglianskas, por quem tenho grande respeito e admiração. Obrigada por ter acreditado e investido no meu capital intelectual permitindo que eu realizasse o sonho de fazer o curso de doutorado na FEA-USP. Agradeço pelo seu estímulo, sabedoria e tranquilidade, compartilhando comigo inúmeras lições de vida.

- Ao meu esposo e grande amor, Lucas Vieira de Araújo, pelo apoio, dedicação, motivação, cumplicidade e compreensão em todas as horas, sem os quais seria impossível finalizar esta jornada.

- Aos meus pais, Luiz Antonio Aligleri e Marly Guilhen Aligleri, por todo auxílio e embasamento para minha trajetória acadêmica e profissional. Seus exemplos admiráveis, inestimáveis conselhos e sapiência me ajudaram muito na reflexão deste trabalho e no desenvolvimento do conteúdo. Comprometo-me que ainda darei a vocês o esperado netinho.

- Ao Instituto Ethos, na figura da Luciana Aguiar e da Ana Lúcia Custódio, pela preciosa colaboração na cessão do banco de dados desta pesquisa, sem o qual o estudo não teria sido possível.

- A Márcia Delatorre e Vanessa Goulart, queridas assistentes do Prof. Dr. Isak, sempre prestativas e acolhedoras, motivando-me a enfrentar os desafios.

- A minha estimada prima Naiara Guilhen Martins, ainda jovem estudante do curso de engenharia de produção, mas já admirável 'anjo da guarda', que incansavelmente me apoiou.

- Ao Prof. Dr. Moacir de Miranda Oliveira Júnior e ao Prof. Dr. João Carlos da Cunha, pela colaboração na qualificação.

- A todos os professores do Programa de Pós-Graduação em Administração da FEA-USP, pelos valiosos conhecimentos e pela competência com que conduzem as atividades do curso.

- Ao meu amigo Prof. Dr. Ivan de Souza Dutra, que me recebeu em sua casa no dia de entrevista de seleção, encorajando-me a iniciar esta trajetória.

- A Prof ${ }^{a}$ Dr $^{a}$ Magali Surjus Pereira, que contribuiu espiritualmente com o meu sonho.

Eu preciso agradecer o incentivo de muita gente e agradeço a Deus por este privilégio.

Muito obrigada!

\footnotetext{
${ }^{1}$ Londrina está a $538 \mathrm{~km}$ da cidade de São Paulo, sendo que realizei aproximadamente 75 viagens.

${ }^{2}$ A circunferência da Terra na Linha do Equador é de $40.075 \mathrm{~km}$.
} 
“A ciência avança por meio de respostas provisórias até uma série de questões cada vez mais sutis." Louis Pasteur (1822-1895) 


\section{RESUMO}

Diversas áreas de conhecimento discutem o modelo tradicional de desenvolvimento econômico e os impactos sobre a vida no planeta. Tais debates incitam variadas demandas sobre as empresas e evocam um redimensionamento dos modelos de gestão. A responsabilidade socioambiental tornou-se um termo em voga, de modo que muitas práticas e instrumentos de gestão foram criados para subsidiar o processo de engajamento e comprometimento das empresas com uma sociedade mais sustentável. Nesta tese, utilizandose da abordagem da economia ecológica, partiu-se do pressuposto que o desenvolvimento sustentável implica numa articulação entre as ciências do homem e as ciências naturais, moldando-se estruturas sociais em coerência com os padrões presentes nos ecossistemas naturais. Nesse contexto, o propósito principal desta pesquisa foi identificar as relações entre algumas ferramentas de gestão para a sustentabilidade e os princípios ecológicos. Foram estudadas sete ferramentas gerenciais compartilhadas pela comunidade empresarial para o alcance de estratégias de sustentabilidade das empresas e quatro princípios ecológicos ou fundamentos básicos da ecologia, que consistem em características existentes na organização dos ecossistemas. Para tanto, pretendeu-se: (1) identificar a presença das ferramentas de gestão e dos princípios ecológicos nas empresas; (2) identificar a associação entre as ferramentas de gestão para a sustentabilidade e os princípios ecológicos quanto à presença, à abrangência e à aplicação; e (3) contribuir para o desenvolvimento teórico e prático dos temas em estudo. Dessa forma, a pesquisa pode ser caracterizada como descritiva e correlacional, com enfoque quantitativo e caráter interdisciplinar. Foi utilizado parte do questionário dos Indicadores Ethos como instrumento de pesquisa, reagrupado em novas categorias, a partir da análise de aglomerados e de correlações policóricas. O estudo envolveu 331 empresas e contou com a inestimável colaboração do Instituto Ethos na cessão do banco de dados dos Indicadores Ethos do ano de 2008. Para a análise estatística do relacionamento entre as variáveis preditoras e resposta em estudo, foi utilizada a técnica da regressão logística ordinal, que permite estabelecer a probabilidade de ocorrência de determinado evento e a importância da variável. Os resultados apontam para uma confirmação parcial das hipóteses de pesquisa. A partir da análise descritiva verificou-se que dentre os quatro princípios ecológicos estudados, as práticas de gestão vinculadas ao equilíbrio dinâmico são as menos presentes nas empresas. Identificou-se também que as ferramentas de gestão possuem associações diferenciadas com os princípios ecológicos. Foram, inclusive, encontradas correlações negativas com significância estatística. As constatações permitem afirmar que existem algumas ferramentas de gestão mais efetivas do que outras e que há complementaridade entre algumas delas. 


\begin{abstract}
Diverse areas of knowledge have addressed the traditional model of economic development and its impacts on the life of the planet. The debates provoke several demands on companies and claim for a re-dimensioning of their management models. The socio-environmental liability has become a fashionable term and many managerial practices and tools have been created to support the engagement and commitment process of the companies with and to a more sustainable society. In this thesis, by means of an ecological economy approach, there is the assumption that sustainable development implies the articulation between man's sciences and natural sciences in which social structures are shaped coherently with patterns found in the natural ecosystems. Within this context, the main purpose of this research is to identify relations between some management tools as shared by the business community and focused on sustainability and ecological principals. Seven managerial tools shared by the business community for the achievement of strategies devoted to the sustainability of the companies and four ecological principals or basic fundaments of ecology, which are existent in the organization of ecosystems, were studied. Therefore, the intention hereby is to (1) identify the presence of management tools and ecological principals in the companies; (2) identify the association between management tools for sustainability and ecological principles as to their presence, scope and application; and (3) contribute for the theoretical and practical development of the themes under this study. Thus, this research is featured as descriptive and co-relational, under a quantitative focus and interdisciplinary character. Part of the Ethos Index Questionnaire was used as a research instrument, regrouped in nine categories based on the analysis of agglomerates and policoric correlations. The study comprehended 331 companies and counted with the valuable collaboration of the Ethos Institute in providing the 2008 Ethos Index databank. The statistic analysis of relationships between predicting variables and response under study was made through the ordinal logistic regression which allowed for the establishment of the occurrence probability of a given event and the importance of the variable. The results indicate a partial confirmation of the research hypothesis. The descriptive analysis evidenced that, among the four ecological principles under study, the management practices related to the dynamic balance are the less frequent in the companies. It was also verified that the management tools have associations that differ in regard to the ecological principles. In fact, negative and statistically significantly corelations were found. The findings allow for the conclusion that some management tools are more effective than others and that they complement one another.
\end{abstract}




\section{SUMÁRIO}

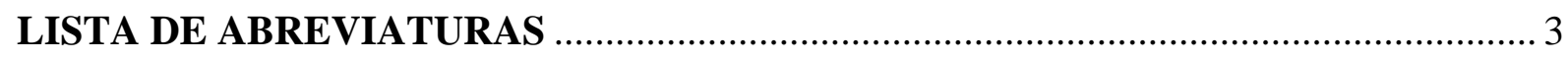

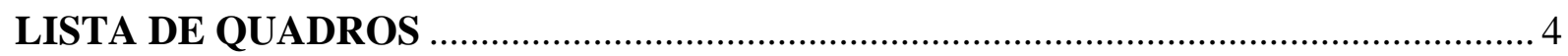

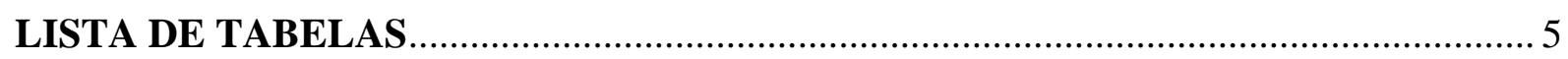

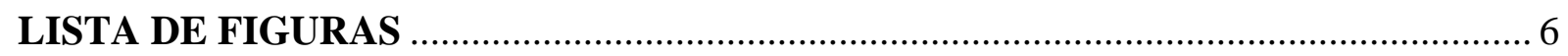

1 INTRODUÇÃ

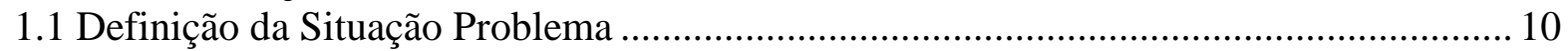

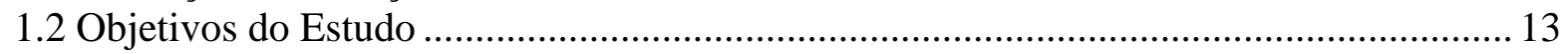

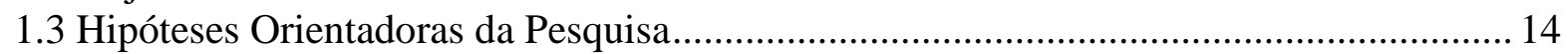

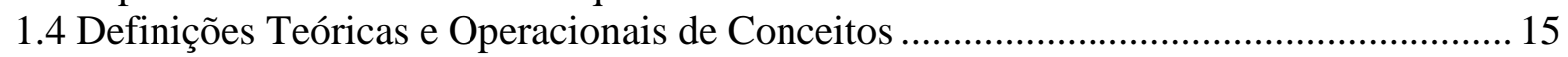

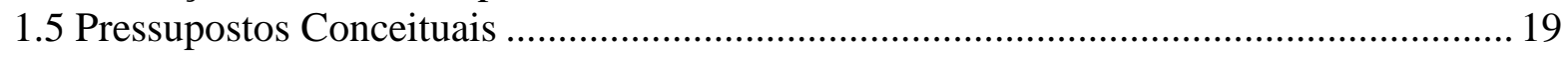

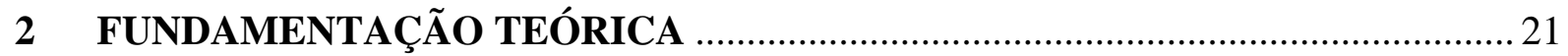

2.1 Desenvolvimento Sustentável: diferentes perspectivas teóricas ................................... 21

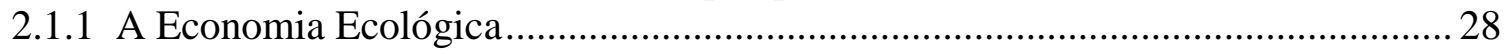

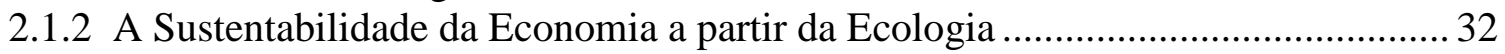

2.2 O Subsídio das Abordagens Filosóficas para a Compreensão da Sustentabilidade ......... 42

2.3 Responsabilidade Social e Sustentabilidade do Negócio ............................................... 46

2.3.1 O Entendimento da Responsabilidade Socioambiental das Empresas....................49

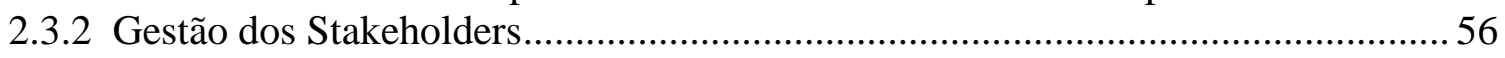

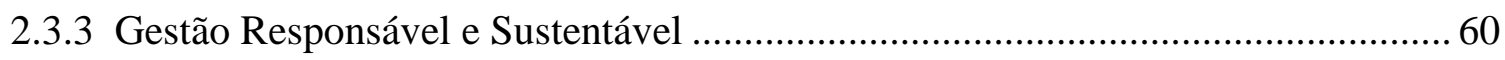

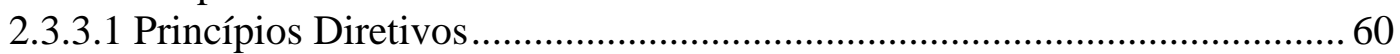

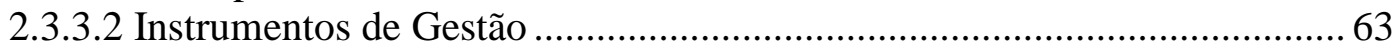

2.3.3.3 .. Modelos de Gestão da Responsabilidade Social: abordagens integradas às

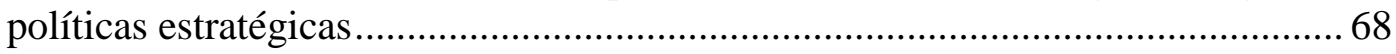

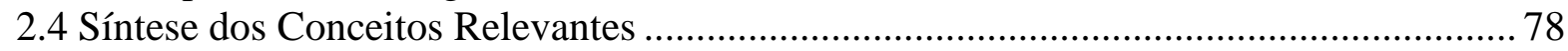

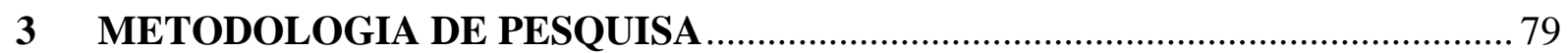

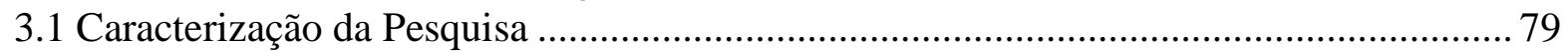

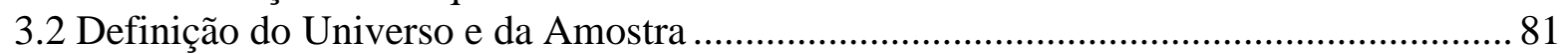

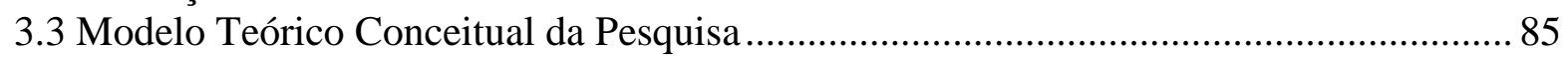

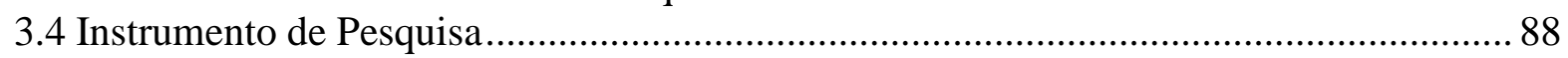

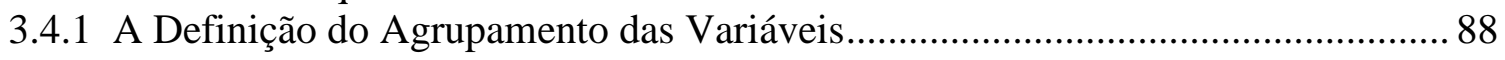

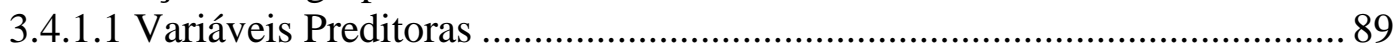

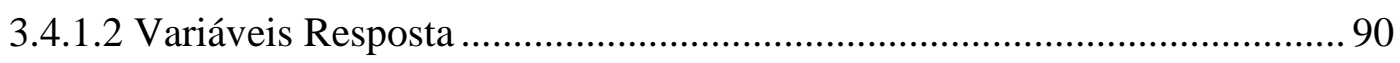

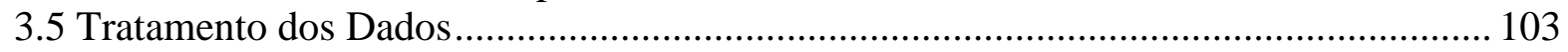

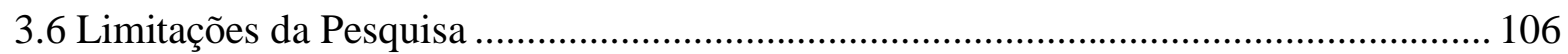

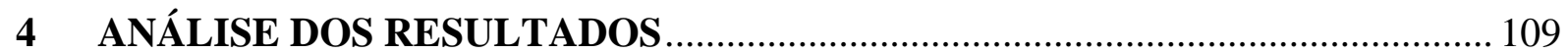

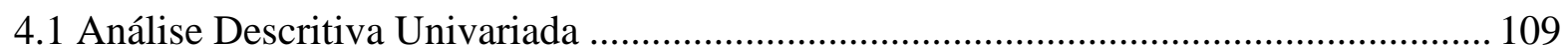

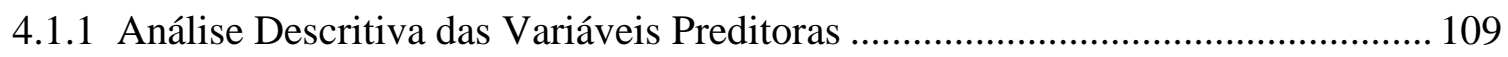

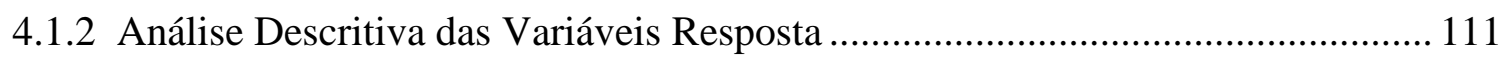

4.1.2.1 Análise Univariada da Macrovariável Rede............................................. 111

4.1.2.2 Análise Univariada da Macrovariável Ciclo ......................................... 114

4.1.2.3 Análise Univariada da Macrovariável Diversidade ............................... 117 
4.1.2.4Análise Univariada da Macrovariável Equilíbrio Dinâmico..................... 120

4.1.2.5Análise Global sobre a Adoção dos Princípios Ecológicos ...................... 124

4.2 Análise das Relações entre as Variáveis Preditoras e Resposta..................................... 126

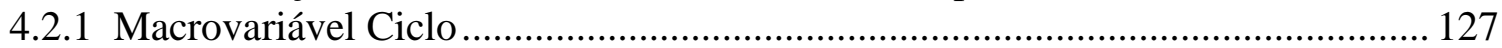

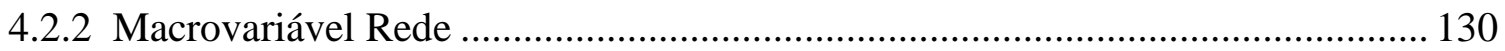

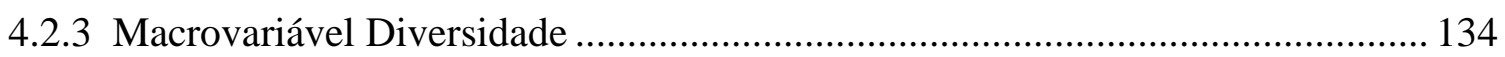

4.2.4 Macrovariável Equilíbrio Dinâmico.................................................................. 138

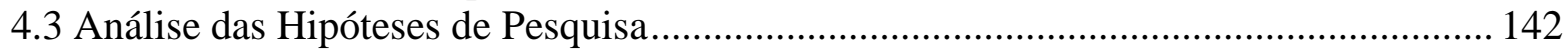

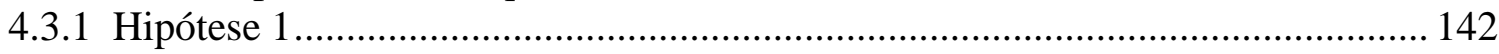

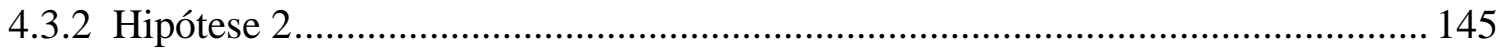

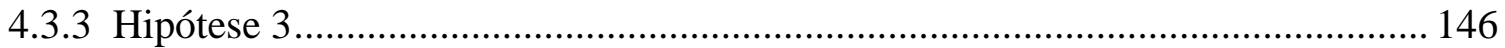

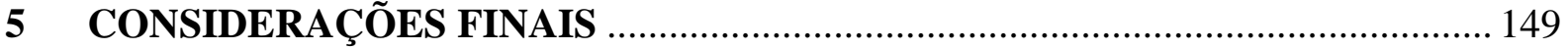

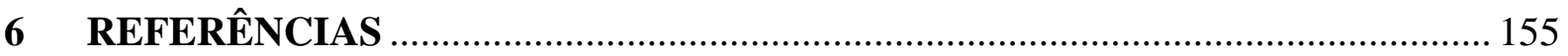

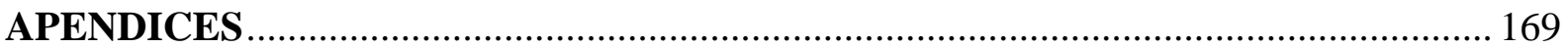




\section{LISTA DE ABREVIATURAS}

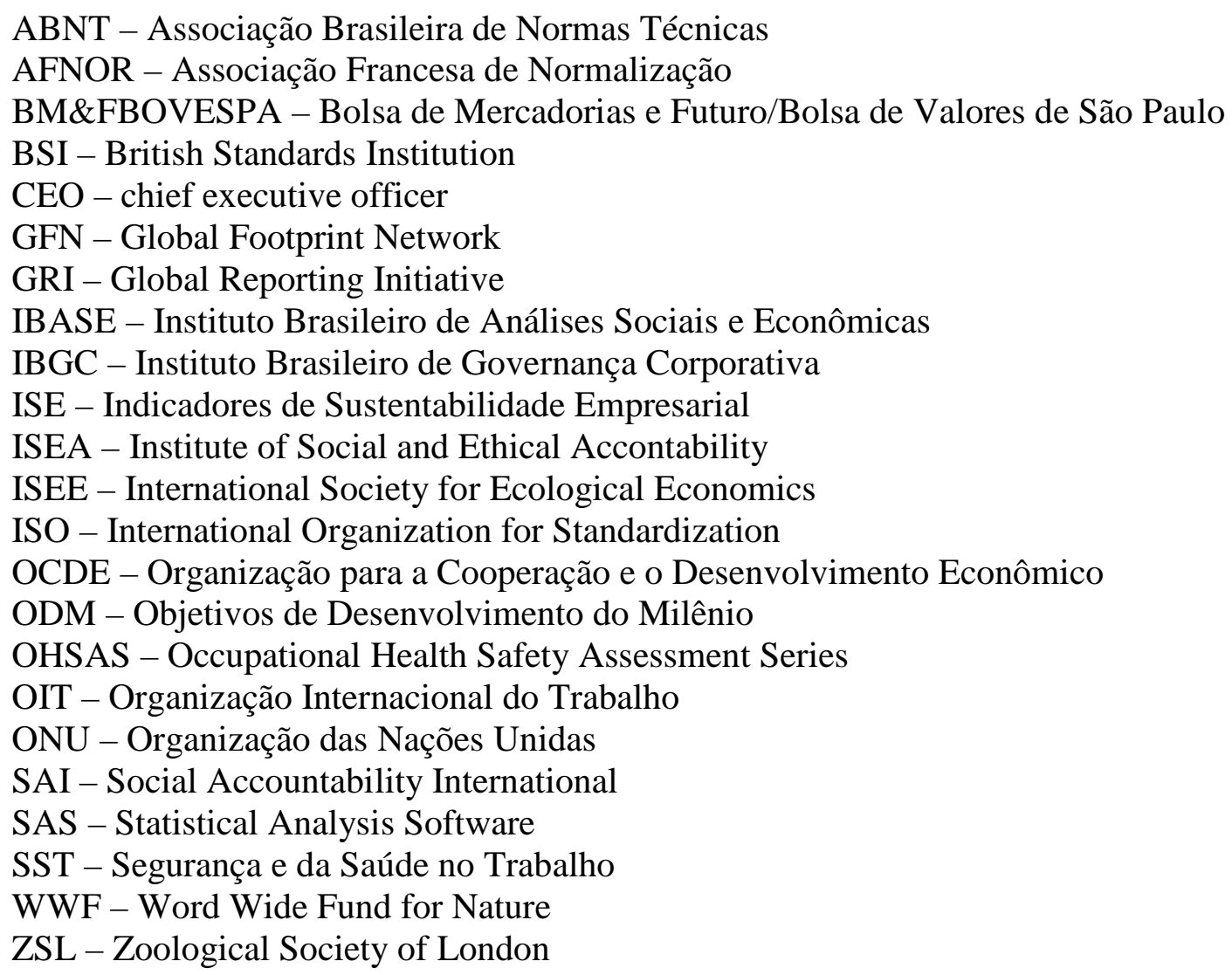




\section{LISTA DE QUADROS}

Quadro 1 - Serviços proporcionados pelos ecossistemas naturais ......................................... 24

Quadro 2 - Principais diferenças percebidas entre economia e ecologia ................................ 33

Quadro 3 - Princípios ecológicos elencados por Capra ........................................................ 37

Quadro 4 - Diferenças entre a ecologia rasa e a ecologia profunda ..................................... 44

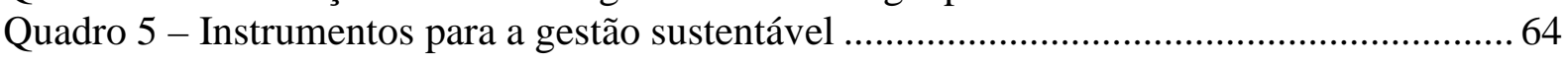

Quadro 6 - Modelos explicativos sobre a responsabilidade social das empresas ................... 69

Quadro 7- Os quatro estágios da maturidade de questões socioambientais ............................ 74

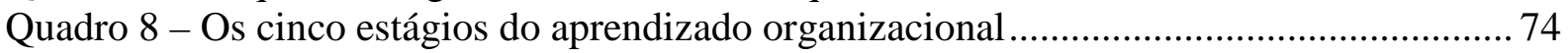

Quadro 9 - Diretriz teórica e conceitos relevantes para a pesquisa ......................................... 78

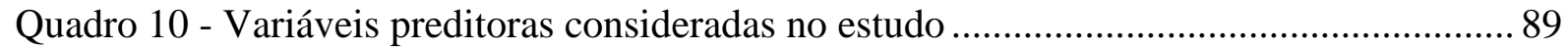

Quadro 11 - Macrovariável rede e as variáveis de análise ................................................... 91

Quadro 12 - Variáveis resposta pertencentes a macrovariável rede...................................... 92

Quadro 13 - Macrovariável ciclo e as variáveis de análise ............................................... 93

Quadro 14 - Variáveis resposta pertencentes a macrovariável ciclo..................................... 94

Quadro 15 - Macrovariável diversidade e as variáveis de análise......................................... 95

Quadro 16 - Variáveis resposta pertencentes a macrovariável diversidade ............................ 96

Quadro 17 - Macrovariável equilíbrio dinâmico e as variáveis de análise.............................. 97

Quadro 18 - Variáveis resposta pertencentes a macrovariável equilíbrio dinâmico ................ 98

Quadro 19 - Procedimentos para utilização da regressão logística ....................................... 104

Quadro 20 - Presença das variáveis preditoras relativas à macrovariável ciclo, com indicação do sinal da estimativa, ou não-significância...................................................... 130

Quadro 21 - Presença das variáveis preditoras relativas à macrovariável rede, com indicação do sinal da estimativa, ou não-significância.................................................... 134

Quadro 22 - Presença das variáveis preditoras relativas à macrovariável diversidade, com indicação do sinal da estimativa, ou não-significância. ..................................... 138

Quadro 23 - Presença das variáveis preditoras relativas à macrovariável equilíbrio dinâmico, com indicação do sinal da estimativa, ou não-significância. .............................. 142

Quadro 24 - Frequiência das correlações positivas entre as variáveis em estudo .................. 143

Quadro 25 - Frequiência das correlações negativas entre as variáveis em estudo .................. 144

Quadro 26 - Correlações positivas entre as variáveis AA 1000 e ISO 14000 e os princípios

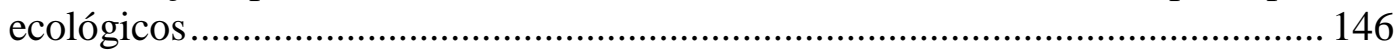




\section{LISTA DE TABELAS}

Tabela 1- Matriz de correlações policóricas inter-itens e de cada item com o escore total das variáveis que compõem a macrovariável rede

Tabela 2- Matriz de correlações policóricas inter-itens e de cada item com o escore total das variáveis que compõem a macrovariável ciclo

Tabela 3- Matriz de correlações policóricas inter-itens e de cada item com o escore total das variáveis que compõem a macrovariável diversidade.

Tabela 4- Matriz de correlações policóricas inter-itens e de cada item com o escore total das variáveis que compõem a macrovariável equilíbrio dinâmico........................... 102

Tabela 5 - Freqüência presença das variáveis preditoras ................................................. 110

Tabela 6 - Freqüência presença das questões pertencentes à macrovariável rede.................. 112

Tabela 7 - Freqüência de presença por categoria de análise da macrovariavel rede .............. 114

Tabela 8 - Freqüência presença das questões pertencentes à macrovariável ciclo................. 115

Tabela 9 - Frequiência de presença por categoria de análise da macrovariavel ciclo ............. 116

Tabela 10 - Freqüência presença das questões pertencentes à macrovariável diversidade ... 118

Tabela 11 - Frequiência de presença por categoria de análise da macrovariavel diversidade 120

Tabela 12 - Frequiência de presença das questões pertencentes à macrovariável equilíbrio dinâmico para a variável VE1 ....................................................................... 121

Tabela 13 - Frequiência presença das questões pertencentes à macrovariável equilíbrio dinâmico para as variáveis VE2 e VE3 ........................................................... 123

Tabela 14 - Coeficientes de regressão logística ordinal para a variável dicotomizada VC1 . 127

Tabela 15 - Coeficientes de regressão logística ordinal para a variável dicotomizada VC2 . 128

Tabela 16 - Coeficientes de regressão logística ordinal para a variável dicotomizada VC3 .129

Tabela 17 - Coeficientes de regressão logística ordinal para a variável dicotomizada VR1 . 131

Tabela 18 - Coeficientes de regressão logística ordinal para a variável dicotomizada VR2 . 132

Tabela 19 - Coeficientes de regressão logística ordinal para a variável dicotomizada VR3 . 133

Tabela 20 - Coeficientes de regressão logística ordinal para a variável dicotomizada VD1 . 135

Tabela 21 - Coeficientes de regressão logística ordinal para a variável dicotomizada VD2 . 135

Tabela 22 - Coeficientes de regressão logística ordinal para a variável dicotomizada VD3 . 136

Tabela 23 - Coeficientes de regressão logística ordinal para a variável dicotomizada VD4 137

Tabela 24 - Coeficientes de regressão logística ordinal para a variável dicotomizada VE1.. 139

Tabela 25 - Coeficientes de regressão logística ordinal para a variável dicotomizada VE2.. 140

Tabela 26 - Coeficientes de regressão logística ordinal para a variável dicotomizada VE3.. 141 


\section{LISTA DE FIGURAS}

Figura 1 - Desenvolvimento da ecologia enquanto ramo de conhecimento............................. 34

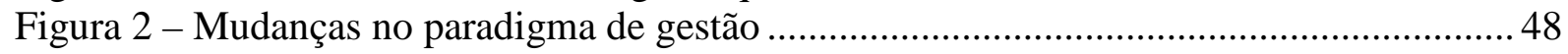

Figura 3 - Pirâmide da responsabilidade social corporativa ................................................ 50

Figura 4 - Modelo das três dimensões da responsabilidade social ...................................... 51

Figura 5 - Conceitos relacionados à responsabilidade social das empresas ...........................52

Figura 6 - Envolvimento da empresa na sociedade: abordagem estratégica............................ 73

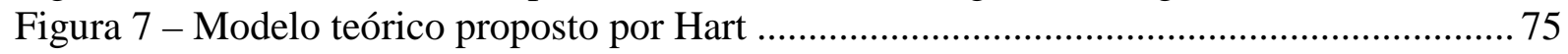

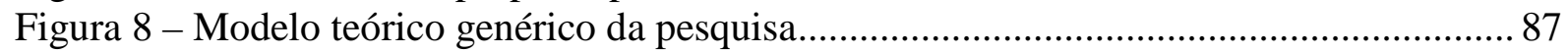

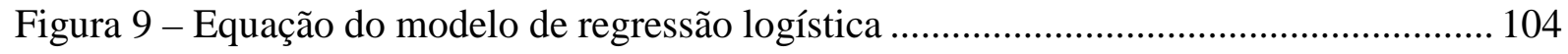

Figura 10 - Equação do logit da razão de chances ............................................................... 105

Figura 11 - Intensidade das relações encontradas entre as ferramentas de gestão e os

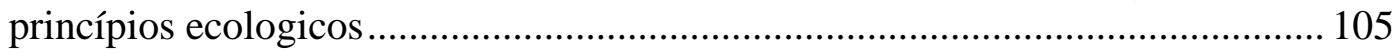




\section{INTRODUÇÃO}

Nos últimos três séculos vislumbrou-se uma elevada expansão da economia, baseada no livre mercado. Desenvolvimento tornou-se sinônimo de crescimento, e as principais motivações da ciência econômica eram a industrialização, os resultados financeiros e a expansão para novos mercados.

O gestor de empresas tinha sua atuação voltada para a busca por resultados quantitativos, centrado em indicadores econômicos-financeiros e lucro a qualquer custo. Os debates nas empresas e na academia giravam em torno do modelo de gestão mais eficaz para alcançar tais ganhos. Não é por acaso que, conforme relatado por Veiga (2008, p. 135), “[...] entre 1700 e 1900 o desempenho europeu foi mais de vinte vezes superior ao dos sete séculos anteriores."

A elevada expansão e o crescimento material ocorreram a partir de vultosa reorganização nos ecossistemas gerando consequências em toda a biosfera (SACHS, 2007, p. 51), iniciando um debate sobre a finalidade e os impactos socioambientais do desenvolvimento. O progresso científico e técnico, bem como o acúmulo de novos conhecimentos acerca da ação antropogênica e das alterações nos sistemas naturais, intensificaram o questionamento ético sobre o caráter selvagem do modelo de desenvolvimento adotado (VIEIRA, 2007, p. 20).

A principal crítica está no economicismo que, por meio de sistemas de estímulos unicamente econômicos, induziu a apropriação predatória da natureza e desperdiçou recursos pelos quais as empresas têm livre acesso ou pagam um custo nominal, a exemplo da água e do ar. Desvelou-se, portanto, a perda da biodiversidade, a poluição de rios, a contaminação do solo com metais pesados e o aumento do efeito estufa levando a catástrofes ambientais e problemas sociais.

Especificamente neste início de século, as preocupações com o meio ambiente, em virtude dos impactos já sentidos pelo homem, assumem proporções cada vez maiores. O Relatório Planeta Vivo 2010, em sua oitava edição, publicado pelo Word Wide Fund for Nature (WWF), juntamente com o Zoological Society of London (ZSL) e a Global Footprint Network (GFN), traz diversas revelações preocupantes: no ano de 2007 a sobrecarga imposta pelas atividades humanas foi $50 \%$ maior que a capacidade regenerativa do planeta; em menos de 40 
anos a biodiversidade global sofreu uma queda de 30\%; 71 países já tem déficit de recursos hídricos que comprometem a saúde dos ecossistemas; e nos últimos 12 anos as emissões de gases de efeito estufa saltaram $35 \%$.

Discute-se, portanto, em diversas áreas do conhecimento, que o modelo tradicional de desenvolvimento tem comprometido a vida no planeta, impactando negativamente a economia de muitas nações e afetando a manutenção dos recursos naturais para as gerações futuras (IPCC, 2007; STERN, 2006). Intensifica-se uma disseminada insatisfação com os impactos adversos provocados pela gestão das organizações e busca-se uma nova relação entre meio ambiente e desenvolvimento.

Aumentam os debates sobre futuros possíveis e sobre o planejamento da ação para o futuro entre a academia, empresas, organizações internacionais e sociedade civil organizada. A nova dinâmica econômica de crescer sem destruir ampliou as discussões sobre o papel e a atuação das empresas induzindo à criação de novos modelos de gestão que incluem compromissos com a responsabilidade socioambiental.

Neste contexto, o desenvolvimento sustentável advindo da exigência por dignidade humana e sustentabilidade ecológica, tornou-se um termo em voga e, portanto, o objetivo de várias empresas, que estão inserindo estrategicamente o tema nas suas missões e processos de gestão.

O desafio do pioneirismo para a mudança do comportamento gerencial levou as empresas a adoção de diversas práticas de gestão que as auxiliassem a ser percebidas como mais comprometidas com a sociedade. Entre essas práticas, estão as que envolvem a eco-eficiência dos processos e o ecodesign de produtos, além da contabilidade ambiental, avaliação da procedência e composição da matéria-prima, análise de alternativas de produtos recicláveis ou de menor impacto ambiental, seletividade de fornecedores e distribuidores ambientalmente corretos e com preocupação em relação à contratação de mão-de-obra infantil, realização de campanha de mídia relacionada a questões de interesse público, respeito aos direitos humanos, diversidade de raça e credos no ambiente organizacional, ética empresarial, definição de diretrizes contra assédio, recolocação de trabalhadores demitidos entre outros. 
Tais práticas abarcaram diversos níveis hierárquicos e setores organizacionais, bem como novos fatores avaliados na tomada de decisão o que implicou na definição de objetivos, metas e indicadores de desempenho específicos relacionados à sustentabilidade (SAVITZ, 2007). Essa nova complexidade levou diferentes atores sociais ao desenvolvimento de instrumentos de gestão e relatórios de análise que suportem a decisão estratégica. Muitos pesquisadores e organizações têm criado suas próprias ferramentas de adesão e monitoramento baseados em princípios, desempenho e processos (LOUETTE, 2007). Tal fato diversificou os temas, as abordagens para a sustentabilidade nas organizações e as perspectivas de engajamento, como os Indicadores Ethos de Responsabilidade Social, The Natural Step, AA 1000, SA 8000, Relatório modelo Global Reporting Initiative (GRI), ISO 14000, Metodologia Zeri, Sigma Project, Matriz de Stakeholders, Pacto Global, Balanço Social modelo IBASE e mesmo a recém-lançada norma ISO 26000.

Em todo o mundo, várias empresas têm se utilizando desses padrões para auxiliá-las na reestruturação dos negócios e na legitimidade da conduta socioambiental responsável. Mas, com essas novas ferramentas organizacionais, será que as empresas estão realmente contribuindo para a sustentabilidade do planeta? Os instrumentos de gestão para a sustentabilidade estão em consonância com a lógica de organização da natureza?

Assim, a intenção deste estudo, que pode ser caracterizado como descritivo, correlacional e interdisciplinar, é identificar, baseado em uma pesquisa teórica e empírica, se em empresas que adotam ferramentas de gestão para a sustentabilidade verifica-se a ocorrência dos princípios ecológicos existentes nos ecossistemas naturais. Em outras palavras, se há, nas organizações empresariais, alguma relação entre o uso da ferramenta de gestão para a sustentabilidade e a adoção de princípios ecológicos.

Para tanto, esta tese está organizada em cinco capítulos. No capítulo 1 é apresentada a contextualização do problema de pesquisa, bem como os objetivos, hipóteses orientadoras do trabalho, definições teóricas e operacionais adotadas e pressupostos conceituais.

No capítulo 2 está o arcabouço teórico sobre a sustentabilidade, discutindo-se os modelos teóricos centrais oriundos da economia para a abordagem do tema. Destaca-se nesse capítulo a proposta de sociedade sustentável realizada pela economia ecológica e a adoção dos princípios ecológicos pelas instituições sociais. Ainda nesse momento, foram elencados os 
principais entendimentos sobre a responsabilidade socioambiental e a sustentabilidade na empresa, apresentando diferentes instrumentos e modelos de gestão que estão sendo adotados pelas organizações.

No capítulo 3 é contemplado o delineamento metodológico do estudo. São expostos os procedimentos e processos metodológicos adotados, destacando-se o modelo teórico da pesquisa, as variáveis utilizadas no estudo e as técnicas de tratamento estatístico dos dados.

No capítulo 4 são apresentados os resultados obtidos na pesquisa, bem como as análises e as discussões. E, finalmente, no capítulo 5 apresenta-se as considerações onde constam os resultados principais e as sugestões para estudos futuros.

\subsection{Definição da Situação Problema}

Ao longo da última década intensificou-se o discurso sobre a necessidade de agir, tendo em vista o presente e o futuro. Portanto, cresceu o envolvimento das empresas nacionais e estrangeiras com políticas e práticas socioambientais, refletindo a apreensão global sobre os impactos adversos provocados pelo modelo de gestão tradicional. A busca pelo resgate do desenvolvimento e das condições de vida exigiu um alinhamento do interesse da sociedade aos interesses da própria organização, trazendo para a dinâmica empresarial a perspectiva do desenvolvimento sustentável.

A necessidade de qualificar o novo desenvolvimento como 'sustentável' reflete a dualidade gerada pelo crescimento econômico contínuo e conservação do meio ambiente. Um novo tipo de interação econômica tornou-se um desejo coletivo tanto quanto a paz, a democracia, a liberdade e a justiça (VEIGA, 2008). Entretanto, a conceituação e operacionalização do que é ser sustentável passa por correntes teóricas distintas e, muitas vezes controversas, que subsidiam diferentes modelos acadêmicos.

Um grupo de teóricos defende que o desenvolvimento sustentável deve ocorrer a partir de soluções locais específicas para problemas e necessidades pontuais (SACHS, 2007). Outros pesquisadores sugerem que o desenvolvimento da tecnologia, introduzindo globalmente 
inovações e substituição de recursos não-renováveis, engendraria um desenvolvimento sustentável (SOLOW, 2000).

Um terceiro grupo defende que um novo tipo de desenvolvimento só ocorrerá a partir da existência de mercados para bens ambientais, precificando direitos de poluição e cotas de emissão, isto é, internalizando as externalidades a partir de uma análise do custo-benefício da alteração do bem-estar (PEARCE; TURNER, 1990). Outra conjunção de teóricos argumenta o incremento do desenvolvimento sustentável a partir da perspectiva da governança, sendo que as linhas de proposição divergem entre a criação de novos instrumentos de regulação, nos quais os Estados soberanos se tornam responsável pela implantação de um conjunto de medidas que induzem a novos comportamentos dos diversos agentes sociais; pesquisadores que sugerem uma governança global das questões ambientais com fundos especiais para projetos de desenvolvimento; e uma gestão inclusiva através de parcerias entre instituições de natureza estatal e não-estatal.

Essas diversas perspectivas refletem a complexidade da abordagem do tema, repercutindo em várias tradições de pensamento, percepções do mundo natural, metas prioritárias e critérios de racionalização a serem compartilhados (VIEIRA, 2007; VEIGA; CECHIN, 2009). Não há, portanto, resposta simples e definitiva sobre o que é uma economia sustentável.

Desta forma, muitos modelos de gestão, na forma de instrumentos e ferramentas gerenciais, foram criados para subsidiar o processo de engajamento das empresas numa perspectiva de comportamento mais sustentável. Por outro lado, ampliaram-se também as críticas às diferentes matrizes propostas por buscarem, para novos projetos de sociedade, soluções pontuais e não uma dimensão transversal e sistêmica com respostas integradas e interligadas a diferentes áreas de conhecimento.

Muitos autores pactuam que um dos principais desacordos entre economia e sustentabilidade deriva do fato de que a natureza é cíclica, enquanto os sistemas industriais e de consumo são lineares e necessitam ser revistos numa perspectiva de padrões e fluxos. Portanto, discutir desenvolvimento sustentável implica em uma articulação entre as ciências do homem e as ciências naturais para melhorar a apreensão sobre a interação dos processos naturais e sociais (SACHS, 2007; MÜELLER, 2007; ODUM; BARRET, 2008). Laszlo (2001) afirma que a vida humana está ligada à vida de outras espécies e se os homens continuarem a interferir nos 
equilíbrios ecológicos estabelecidos entre as diversas espécies, o bem estar e a sobrevivência do homem estarão ameaçados. Mas, segundo Veiga (2008, p. 188), “[...] é patente o generalizado desconhecimento das formulações conceituais da ecologia e das leis fundamentais da termodinâmica [...] residindo em um dos problemas centrais da compreensão do desenvolvimento sustentável.”

Nesta mesma perspectiva, Capra $(1997,2002,2006)$ enfatiza que os princípios de organização dos ecossistemas são idênticos aos princípios de organização de todos os sistemas vivos e defende em seus trabalhos que conhecer a forma de organização e os ciclos ecológicos da natureza apresentam-se como um importante modelo para o sistema econômico sustentável. O autor advoga ainda que não é necessário inventar comunidades humanas sustentáveis a partir do nada, pode-se moldar as estruturas materiais e sociais em coerência com os ecossistemas naturais. Para tanto, Capra (1997 e 2002) argumenta que os princípios básicos da ecologia redes, ciclos, parcerias, diversidade, interdependência, fluxos, flexibilidade, equilíbrio dinâmico - podem ser usados como um padrão de organização para maximizar a construção de organizações e comunidades humanas sustentáveis.

Na medida em que as organizações precisam inovar em estruturas, padrões e processos de gestão para ter um comportamento mais socioambientalmente responsável e alcançar a sustentabilidade, torna-se importante entender se a dinâmica adotada pelas empresas é coerente com a sustentabilidade dos sistemas vivos.

Este estudo tomou os princípios ecológicos, definidos como os fundamentos de organização dos ecossistemas, como um modelo efetivo de compreensão da contribuição das empresas para o desenvolvimento de uma sociedade mais sustentável. Desta forma a pergunta que se propõe é: Qual é a relação entre o uso de ferramentas de gestão para a sustentabilidade e a adoção dos princípios ecológicos pelas empresas?

Esta tese relaciona, portanto, conceitos oriundos da biologia, especificamente no ramo da ecologia, às ferramentas de gestão. A aplicação de conceito de outras áreas da ciência para a resolução de problemas nas empresas não é novidade, uma vez que a teoria administrativa evoluiu tomando emprestado ideias, técnicas e conceitos das ciências naturais e sociais (ZACCARELLI, 1971; ZACCARELLI et al, 1980; HAWKEN et al, 2000). E, talvez, isso 
ajude a explicar a natureza multidisciplinar da administração de empresas na resolução de questões que lhe são próprias (GIOVANNINI; KRUGLIANSKAS, 2004, p 20).

Portanto, responder à pergunta de pesquisa, que envolve uma perspectiva interdisciplinar entre administração e ecologia, pode contribuir para conhecer os ferramentais de gestão mais efetivos e consistentes com os princípios de sustentação da vida e, por consequência, melhorar a configuração de atuação e o formato de resposta das empresas às críticas e às demandas socioambientais.

A expectativa é que os resultados dessa tese contribuam com executivos no processo de decisão para a escolha e incorporação das ferramentas e práticas de gestão, promovendo a construção de relações que preservem a integridade da empresa e do planeta. Acredita-se que tais resultados trarão benefícios tanto para as empresas, que terão seus modelos de gestão mais legitimados criando valor ao acionista, quanto para a sociedade que terá organizações alinhadas à capacidade intrínseca da natureza de sustentar a vida.

Para a ciência possibilitará aprofundar a reflexão sobre a sustentabilidade nas empresas e o progresso das teorizações numa perspectiva multidisciplinar, a partir da integração de duas áreas de conhecimento. Desta forma, pretende-se que o trabalho reforce a importância da complexidade na assimilação de formatos organizacionais sustentáveis.

\subsection{Objetivos do Estudo}

Para Giovannini e Kruglianskas (2004), as organizações e a sociedade, enquanto sistemas dinâmicos e não-lineares, possuem um comportamento complexo e estão inseridas num ambiente também complexo. Portanto, os autores destacam que não se deve buscar encontrar uma relação de causa e efeito para fazer previsões e controlar o sistema. Mas, entender a dinâmica das inter-relações que permeiam o comportamento do sistema, isto é, que tipo de estimulação existe.

Assim, o objetivo da pesquisa é identificar e analisar as relações entre as ferramentas de gestão para a sustentabilidade e os princípios ecológicos, com o propósito de contribuir para o avanço do conhecimento em administração de empresas. 
Quanto aos objetivos específicos, o trabalho visa:

a) Identificar a presença das ferramentas de gestão e dos princípios ecológicos nas empresas.

b) Identificar a associação entre as ferramentas de gestão para a sustentabilidade e os princípios ecológicos, quanto à presença, à abrangência e à aplicação.

\subsection{Hipóteses Orientadoras da Pesquisa}

Nesta tese, considerando a diretriz teórica adotada e diante dos objetivos apresentados, definiu-se três hipóteses orientadoras da pesquisa, buscando evidência de presença $\left(\mathrm{H}_{1}\right)$, evidência de amplitude $\left(\mathrm{H}_{2}\right)$ e evidência de aplicação $\left(\mathrm{H}_{3}\right)$ entre as variáveis estudadas. Destaca-se que as hipóteses formuladas possuem o papel exclusivo de direcionar o raciocínio da pesquisadora na formulação e execução do estudo, sem a pretensão de testar ou validar resultados.

- Hipótese ${ }_{1}$ : A existência de ferramentas de gestão para a sustentabilidade está positivamente associada à presença de princípios ecológicos nas empresas.

Acredita-se que as ferramentas de gestão para a sustentabilidade estão coerentes com a dinâmica adotada dos sistemas vivos indicando que relações econômicas apresentam reciprocidade com as outras formas de vida, apresentando um padrão sustentável de apoio mútuo. Supõe-se que as práticas assimiladas pelas empresas seguem o padrão de organização dos ecossistemas naturais, não desprezando aspectos de ordem ecológica dos sistemas.

- Hipótese ${ }_{2}$ : Quanto maior o número de ferramentas de gestão para a sustentabilidade presentes nas empresas, maior a evidência dos princípios ecológicos nas mesmas.

Acredita-se que quanto mais ferramentas de gestão para a sustentabilidade estiverem presentes na empresa, maior o envolvimento da mesma com os princípios ecológicos, uma vez que a adoção é, na maioria das vezes, gradativa. Supõe-se, portanto, que o maior envolvimento da gestão com ferramentas para a sustentabilidade implica em mais ajustes estruturais e novos mecanismos para ampliar o relacionamento com os diferentes públicos de relacionamento (stakeholders). 
- Hipótese ${ }_{3}$ : Diferentes ferramentas de gestão para a sustentabilidade levam à assimilação de diferentes características ecológicas pelas empresas.

As ferramentas de gestão para a sustentabilidade possuem escopo variado. Algumas enfocam princípios de comportamento, outras descrevem orientações práticas sobre o que deve ser feito e um terceiro grupo se concentra em metas e lista de indicadores em relação aos quais as empresas deveriam comparar-se. Supõe-se que as características da ferramenta adotada implicarão em configurações organizacionais diferenciadas, isto é, modos diferentes de organizar e coordenar as atividades na empresa, bem como relacionar-se com os stakeholders.

\subsection{Definições Teóricas e Operacionais de Conceitos}

Neste trabalho alguns conceitos fundamentais como Desenvolvimento Sustentável, Sustentabilidade Empresarial, Responsabilidade Socioambiental, Ferramentas de Gestão para a Sustentabilidade, Princípios Ecológicos e Meio Ambiente são recorrentes. Portanto, algumas definições operacionais são necessárias. Destaca-se que tais conceitos, embora baseados na literatura, não são necessariamente assumidos pela unanimidade dos autores, sendo apresentados de forma sintética para atender a estrutura da tese.

\section{Desenvolvimento Sustentável:}

Um conceito político cunhado em 1987 no Relatório Nosso Futuro Comum elaborado pela Comissão Mundial sobre Meio Ambiente e Desenvolvimento e definido como "[...] aquele que satisfaz as necessidades do presente sem comprometer a capacidade das futuras gerações satisfazerem suas próprias necessidades.” (BRUNDTLAND, 1988, p. 46).

Diversas concepções teóricas já foram formuladas para explicar como alcançar esta proposta de desenvolvimento, conforme será apresentado no capítulo 2 deste trabalho. Nesta tese, o desenvolvimento sustentável é entendido como um paradigma que possibilita continuidade da vida, assegurando a manutenção da civilização humana ao longo das gerações. Para tanto, pode ser definido como a harmonização da eficiência econômica, equidade social e prudência ecológica implicando na compatibilização dos modelos de produção e gestão das instituições 
sociais com o sistema de organização e conservação da natureza. Tal definição foi desenvolvida a partir de Sachs (2007), Veiga (2008) e Tambellini (2009).

\section{Responsabilidade Socioambiental:}

Responsabilidade socioambiental e responsabilidade social podem ser entendidas, neste trabalho, como sinônimos e como um modo das empresas engajarem-se na busca pela sustentabilidade. O termo é definido por uma forma de gestão pró-ativa que aceita um compromisso moral de responder pelos impactos de suas decisões e atividades sobre o meio ambiente e a sociedade, incorporando o diálogo e as expectativas dos públicos nas políticas e práticas gerenciais, contribuindo para o desenvolvimento sustentável. Tal definição foi desenvolvida a partir de Instituto Ethos (2010) e ISO (2010).

\section{Gestão Sustentável:}

Uma abordagem de negócios que considerada o padrão de organização dos ecossistemas nos processos de decisão e nas práticas de gestão contemplando indicadores de avaliação nas dimensões econômica, ambiental e social. Está vinculado ao conceito do triple bottom line, ou tríplice resultado proposto por Elkington (2001) e também a ideia dos princípios ecológicos (CAPRA, 1997, 2002, 2006).

\section{Sustentabilidade Empresarial:}

Nesta tese, utiliza-se o conceito proposto por Savitz (2007, p. 2), que define como empresa sustentável aquela que "gera lucro para os acionistas, ao mesmo tempo em que protege o meio ambiente e melhora a vida das pessoas com quem mantém relações." A sustentabilidade empresarial está, portanto, relacionada à gestão socioambientalmente responsável da empresa.

\section{Sociedade Sustentável:}

É uma coletividade humana que busca desenvolver-se considerando os efeitos das atividades antropogênicas sobre o ambiente natural. Para tanto, integra o bem estar com o respeito à capacidade de organização e renovação dos ecossistemas naturais, garantindo qualidade de vida para a geração presente e assegurando a continuidade das gerações futuras. 


\section{Meio Ambiente:}

Entendido nesta tese como sinônimo de natureza e meio natural. Abrange o inventário de recursos naturais existentes no planeta, que permite, abriga e rege a vida em todas as suas formas.

\section{Biologia:}

É o ramo do conhecimento que estuda as relações entre os seres vivos e o ambiente onde vivem. Analisa as conexões que compõem a vida. Para tanto, muda o foco dos estudos da perspectiva ambiental dos organismos para um complexo mecanismo de relações recíprocas entre as populações de uma comunidade e o ambiente.

\section{Ferramentas de Gestão:}

Ferramentas gerenciais de diferentes tipologias (normas, diretrizes, princípios e guias) compartilhados na comunidade empresarial e utilizados como modelos que auxiliam no alcance da estratégia de sustentabilidade das empresas. Existem diversos padrões de referência, no âmbito global, nacional e setorial, disponíveis e utilizados pelas empresas como mecanismos de indução ao desenvolvimento sustentável. Neste trabalho, optou-se por conhecer a adoção de sete ferramentas, conforme justificativa apresentada na metodologia de pesquisa disponível no capítulo 3. Tais ferramentas foram definidas operacionalmente como:

a) Pacto Global: possui declaração formal de operações em concordância com o conjunto de dez princípios desenvolvidos pela Organização das Nações Unidas (ONU), ligados a direitos humanos, relações de trabalho, meio ambiente e combate a corrupção.

b) Código de Conduta: possui um documento formal que explicita padrões e políticas de comportamento a serem incorporados aos processos de trabalho e às atitudes das pessoas envolvidas com a empresa.

c) Diretrizes da Organização para Cooperação e Desenvolvimento Econômico (OCDE) para Empresas Multinacionais: possui declaração formal de atuação organizacional em concordância com os princípios e padrões de boas práticas definidos pela OCDE para as operações das empresas multinacionais em todo o mundo.

d) ISO 14000: possui certificação da norma ISO 14001, desenvolvida pela International Organization for Standardization (ISO), padrão auditável voltado para um sistema de gestão ambiental. 
e) AA 1000: adota a Norma AA 1000, desenvolvida pelo Institute of Social and Ethical Accountability, padrão auditável que fixa práticas para prestação de contas para assegurar a qualidade da contabilidade, da auditoria e do relato social.

f) SA 8000, BS 8800 e OSHAS 18001: possui certificação SA 8000, BS 8800 ou OSHAS 18001, padrões auditáveis voltados para a humanização, integridade física dos colaboradores, objetivando a melhora nos níveis de desempenho da saúde, segurança e relações de trabalho.

g) Balanço Social: elabora anualmente um relatório de desempenho descrevendo suas ações sociais e ambientais, incorporando aspectos quantitativos.

As ferramentas de gestão para a sustentabilidade são propriedades estudadas nesta pesquisa e foram categorizadas como variáveis preditoras.

\section{Princípios Ecológicos:}

Também denominado de princípios básicos da ecologia ou princípios básicos da sustentabilidade. É o ponto de partida, ideias elementares ou fundamentos da organização dos ecossistemas, que a natureza fez evoluir para sustentar a vida no planeta.

Nesta tese, serão analisados quatro princípios ecológicos (CAPRA, 1997, 2002, 2006; MÜELLER, 2007; ODUM, 1997; ODUM e BARRETT, 2008), utilizados como referência para verificar se as atividades empresariais, de forma geral, estão próximas dos preceitos de sociedade sustentável.

A construção das definições operacionais objetivou conceber um entendimento para aplicação das ideias na conjuntura das empresas. Para tanto, nesta tese, os princípios ecológicos são conceituados como:

a) Rede: coordenação e arranjo de empresas de uma cadeia produtiva em aspectos socioambientais, decorrentes da racionalidade estratégica, transpondo limites organizacionais e almejando identidade de atuação socioambiental dos diferentes componentes.

b) Ciclo: gerenciamento sistêmico dos danos e impactos potenciais do ciclo da matéria de produtos e serviços causados pela empresa sobre o ambiente. 
c) Diversidade: mecanismos para interação, comunicação e relacionamento com diferentes públicos, abrangendo a pluralidade no ambiente interno e proporcionando associações e parcerias junto aos stakeholders.

d) Equilíbrio Dinâmico: monitoramento de variáveis socioambientais na dinâmica de gestão servindo como laços de realimentação para o aprendizado e a adaptação da empresa.

Os princípios ecológicos são propriedades estudadas neste trabalho e foram classificados como variáveis respostas. Mais informações sobre a formação das variáveis encontram-se no item 3.4.

\subsection{Pressupostos Conceituais}

O pressuposto central deste trabalho está vinculado às ideias desenvolvidas por Capra (1997, 2002, 2006), Müller (2007) e Odum e Barrett (2008). Toma-se como premissa que o modelo ideal para um desenvolvimento mais sustentável está ancorado em padrões e processos pelos quais as empresas interagem. Esses devem ser estruturados para estar coerentes com os princípios ecológicos, isto é, em sintonia com as características que possibilitam a manutenção da vida. Portanto, é importante aprender como a natureza está organizada para exibir os mesmos princípios básicos de ordenamento nas empresas. Nesta tese, admite-se que para as empresas fomentarem sociedades sustentáveis devem seguir o modelo dos ecossistemas da natureza.

Outros pressupostos conceituais elencados foram assumidos para a pesquisa a partir desta conjectura:

a) Empresas são sistemas abertos, uma vez que na atividade gerencial há um contínuo processo de interação e troca com o ambiente na forma de fluxo de material, energia e recursos. Portanto, empresa e ambiente são compreendidos em estado de interação e dependência mútua, devendo atingir uma relação apropriada com o meio, caso queiram perdurar (BERTALANFFY, 1975; MORGAN, 1996; CECHIN; VEIGA, 2010).

b) Empresas são sistemas vivos. Segundo a biologia “[...] o comportamento de um organismo vivo é determinado por sua estrutura, à medida que a estrutura muda no 
decorrer do desenvolvimento do organismo e da evolução da espécie, muda também seu comportamento.” (CAPRA, 1997, p. 103). Dinâmica semelhante pode ser observada nas empresas, pois realizam adaptações estruturais contínuas para se adequar aos estímulos internos e externos, mudando regras de inter-relacionamento e criando uma nova ordem, mas preservando seus padrões de identidade (CAPRA, 2002; GIOVANNINI; KRUGLIANSKAS, 2004).

c) A empresa está, portanto, em acoplamento estrutural com o meio, isto é, em condicionamento mútuo das estruturas (MATURANA; VARELA, 2001). Ao mesmo tempo em que as organizações constroem suas práticas, também estão concebendo o ambiente em que atuam num padrão de criação mútua. Portanto, a sobrevivência da empresa “[...] só pode ser sobrevivência com o ambiente e nunca sobrevivência contra o ambiente ou contexto no qual se está operando." (MORGAN, 1996, p. 252).

d) Há uma interdependência de todos os fenômenos e, segundo Capra (1997 e 2002), o homem é parte da natureza, inserido em seus processos cíclicos. O padrão da vida é um modelo de redes. Portanto, existe acoplamento e interdependência entre indivíduos e sociedades nos diversos âmbitos de organização. Tal perspectiva é denominada de Ecologia Profunda, embasada em conceitos da teoria da complexidade.

e) A responsabilidade socioambiental como forma de gestão pró-ativa que aceita um compromisso moral de responder pelos impactos de suas decisões e atividades sobre o meio ambiente e a sociedade, leva a sustentabilidade do negócio (BARBIERI; CAJAZEIRA, 2009; SAVITZ, 2007; NASCIMENTO et al, 2008; SCHARF, 2004). Os comportamentos e atitudes consistentes com as expectativas da sociedade e alinhados às operações de negócio elevam a reputação e credibilidade da empresa e, por consequência, impulsionam o valor de mercado, o desempenho econômico e a longevidade da mesma (ALIGLERI et al, 2009). 


\section{FUNDAMENTAÇÃO TEÓRICA}

Neste capítulo é apresentado o arcabouço teórico que subsidia a pesquisa. Em seu conteúdo discutem-se os modelos teóricos centrais oriundos da economia para o entendimento do desenvolvimento sustentável. É realçada também a proposta de sociedade sustentável realizada pela economia ecológica e a adoção dos princípios ecológicos pelas instituições sociais. Após isto, apresenta-se brevemente uma discussão sobre as concepções filosóficas que embasam a sustentabilidade da economia a partir da ecologia.

Os principais entendimentos sobre a responsabilidade socioambiental e a sustentabilidade na empresa também estão presentes no capítulo, destacando-se a relação existente entre os dois temas. São elencados os desafios para a gestão e os variados aspectos que envolvem o comportamento de uma empresa responsável e sustentável. Enumera-se ainda diversos princípios diretivos, instrumentos e modelos para a gestão que servem como meio pelos quais as empresas buscam o desenvolvimento sustentável da sociedade e do próprio negócio.

\subsection{Desenvolvimento Sustentável: diferentes perspectivas teóricas}

O modelo de desenvolvimento econômico adotado pela sociedade proporcionou aumento da riqueza e da fartura em um grande número de países embasado, principalmente, na intensa exploração dos recursos naturais (CARVALHO et al, 2007). Tal fato foi subsidiado pela lógica do crescimento como desenvolvimento que ocupava lugar de grande relevância nos estudos econômicos, estabelecendo discussões apenas em torno das modalidades e usos do crescimento (SACHS, 2007). Veiga e Cechin (2009, p.1) explicam este enfoque:

Como se sabe, para que o pensamento econômico pudesse avançar, havia sido necessário que um sistema de trocas de curto prazo entre os agentes fosse mentalmente separado de todo o resto da realidade, pois o contrário engendra necessariamente uma complexidade com a qual é dificílimo lidar.

A transformação da sociedade e da economia alicerçada neste tipo de pensamento alterou de várias maneiras o mundo natural, fomentando desequilíbrios ambientais e sociais e ocasionando um processo contínuo e acelerado de desperdícios, degradação, poluição e miséria (VEIGA, 2008). 
Loyola (1997) destaca que empresários e gestores começaram a perceber que diversos recursos naturais utilizados como matéria-prima, antes abundantes e baratos, começaram a ter um custo de extração mais caro e um preço incrementado. Em consequência do congestionamento do solo, do surgimento de grandes indústrias e do desenvolvimento de grandes centros urbanos, o mesmo também ocorreu em relação à mão-de-obra, uma vez que trabalhadores precisavam movimentar-se de maneira mais cara e longa.

A compreensão de que os problemas sociais e ambientais têm raízes no sistema econômico leva a questionar o caráter agressivo do crescimento da economia. Intensifica-se a crítica ao modelo de progresso econômico adotado nas últimas décadas, apontando um conflito e até uma possível incompatibilização entre crescimento econômico e a preservação de recursos naturais (AMAZONAS, 2002).

Debates e diferentes proposições para a resolução do embate afloram nas últimas décadas do século XX. Crescimento econômico zero, conhecido como proposta neo-malthusiana, e o direito de poluir, defendido por países conhecidos como terceiro mundo são exemplos de tentativas de respostas para compatibilizar crescimento e desenvolvimento. Portanto, em diversos campos de conhecimento, amplia-se a discussão sobre a melhor proposta.

Neste contexto, a expressão desenvolvimento sustentável acaba legitimando-se como uma terceira via para afirmar a possibilidade de conciliação entre desenvolvimento econômico e preservação ambiental (AMAZONAS, 2002; VEIGA, 2008).

Uma perspectiva mais consolidada deste novo tipo de desenvolvimento denominado de sustentável é proposta no relatório "Nosso Futuro Comum”, publicado em 1987, que delineia um conceito político, chamando a atenção para uma nova postura ética, caracterizada pela responsabilidade tanto entre as gerações quanto entre os membros da sociedade atual (BRÜSEKE, 2003). O termo é definido como “[...] aquele que satisfaz as necessidades do presente sem comprometer a capacidade das futuras gerações satisfazerem suas próprias necessidades." (BRUNDTLAND, 1988, p. 46).

Os economistas intensificam a discussão e formulação de diversas teorias para direcionar a economia rumo a um desenvolvimento mais sustentável. Loyola (1997) afirma que o 
envolvimento da economia com os problemas ambientais nasceu a partir da necessidade de controlar o mau uso dos bens ambientais, em especial, a poluição. Assim, os pesquisadores denominados de economistas ambientais reconhecem as imperfeições no mercado que precisam ser corrigidas e acreditam que as mesmas podem ser ajustadas pela eficiência alocativa do mercado e pelo desenvolvimento tecnológico. Portanto, as proposições defendidas pelos mesmos utilizam-se de preceitos da economia neoclássica, levando Cavalcanti (2003b, p. 152) a afirmar que a economia ambiental “[...] coloca o sistema ecológico na perspectiva da abordagem econômica."

Duas questões que têm sido muito debatidas entre acadêmicos que discutem o relacionamento da economia com o meio ambiente referem-se à utilização dos recursos naturais e a possibilidade de sua substituição por outros tipos de capital. No que compete à utilização dos recursos naturais, há uma relevante discussão ligada à valoração econômica dos elementos do meio ambiente, isto é, a internalização monetária das externalidades via mercado.

A quantificação dos impactos ambientais das atividades produtivas, de forma negativa ou positiva, incorporados na formação de valor dos bens obtidos por meio da precificação é apresentada por muitos teóricos da economia ambiental como o único caminho possível para um planejamento de ações compatíveis com um desenvolvimento mais sustentável. Denardin e Sulzbach (2002) destacam que para atribuir valor monetário às externalidades empregam-se as técnicas de valoração de contingências nas quais são feitas suposições dos impactos adversos causados pela atividade ao meio ambiente, bem como avaliadas as contribuições advindas dos recursos ou serviços ambientais não negociáveis no mercado. Veiga (2007, p. 37) complementa afirmando que: "Esse valor começou então a ser medido por uma espécie de análise de custo-benefício da alteração do bem-estar."

Tal proposição implica em impostos e subsídios para corrigir imperfeições do mercado e internalizar as externalidades negativas. A fixação de preços para os recursos naturais exauríveis como proposto pelo Protocolo de Kyoto e o princípio do poluidor-pagador são exemplos de soluções econômicas que seguem esta linha de análise (VEIGA, 2008).

Entretanto, diversos autores apresentam críticas a esse raciocínio, argumentando um reducionismo econômico, numa tentativa de "[...] comensurar o incomensurável." (CAVALCANTI, 2003b, p. 152). No que se refere à fixação de preço, segundo Veiga (2008), 
as críticas baseiam-se no elevado grau de incerteza das relações de causa e efeito com escalas múltiplas de tempo e espaço, levando a um alto grau de arbitrariedade. Um estudo empírico realizado por Figueroa (2005, p. 103) reforça, entre os seus resultados, essa proposição ao afirmar que: "Os resultados mostram que os métodos de valorização ambiental recolhem uma mínima parte do valor dos bens e serviços associados à biodiversidade e, nos casos onde são aplicados, os supostos necessários tem alto grau de arbitrariedade".

Na opinião dos críticos desta perspectiva é muito difícil, por exemplo, dimensionar e avaliar a amplitude da poluição. Veiga e Cechin (2009, p. 2) corroboram ao refletir:

Seria possível atribuir preço à vida humana, aos ecossistemas, ou aos esquemas que regulam o clima? Qualquer preço atribuído seria arbitrário além de cientificamente duvidoso. E quando se trata de decisões morais que envolvem o futuro da humanidade, a métrica para se comparar valores não pode ser única. Para se comparar lucros, direitos humanos, e perda de biodiversidade, a métrica não pode ser a mesma. São valores incomensuráveis.

E, além disso, alguns teóricos alertam que há o perigo de levar as pessoas a acreditar que eles valem o que os cálculos mostram, esquecendo-se dos serviços ambientais de suporte à vida humana e não-humana prestados pela natureza como a produção de oxigênio e a purificação do ar pelas plantas, a estabilidade das condições climáticas com a moderação das temperaturas, a estabilidade das chuvas e da força dos ventos e das marés (LOYOLA, 1997; CAVALCANTI, 2003a; BRAND, 2009), conforme apresentado no Quadro 1. Portanto, Sachs (2007, p. 84) chega a afirmar que estas propostas “[...] nos fazem sorrir por sua artificialidade."

Quadro 1 - Serviços proporcionados pelos ecossistemas naturais

\begin{tabular}{|c|l|}
\hline Categorias & \multicolumn{1}{|c|}{ Serviços } \\
\hline Provisão & $\begin{array}{l}\text { Alimentos, água, madeira para combustível, fibras, bioquímicos, recursos } \\
\text { genéticos. }\end{array}$ \\
\hline Regulação & $\begin{array}{l}\text { Regulação climática, regulação de doenças, regulação biológica, regulação e } \\
\text { purificação de água, regulação de danos naturais, polinização. }\end{array}$ \\
\hline Culturais & $\begin{array}{l}\text { Ecoturismo e recreação, espiritual e religioso, estético e de inspiração, } \\
\text { educacional, senso de localização, herança cultural. }\end{array}$ \\
\hline Suporte & $\begin{array}{l}\text { Formação do solo, produção de oxigênio, ciclagem de nutrientes, produção } \\
\text { primária. }\end{array}$ \\
\hline
\end{tabular}

FONTE: MILLENNIUM ECOSYSTEM ASSESSMENT - MEA, 2003, p. 57.

Já na perspectiva que discute a possibilidade de uso e substituição dos recursos, outro embate também é travado entre os teóricos. As diferentes interpretações levam a duas maneiras distintas de abordar a questão ambiental na economia: a primeira denominada de 
sustentabilidade fraca e a segunda nomeada de sustentabilidade forte. (ANDRADE; ROMEIRO, 2009; CECHIN; VEIGA, 2010; VEIGA, 2007).

A sustentabilidade fraca, sustentada pela teoria convencional sobre o crescimento econômico e também economia ambiental, é defendida por Solow (2000). O autor acredita que a natureza não deve ser considerada um obstáculo à expansão, pois, em sua opinião, não existe o problema da escassez absoluta de recursos naturais. Portanto, o capital natural não necessita receber tratamento diferenciado uma vez que pode ser substituído por outros construídos pelo homem.

Solow (2000) defende que o desenvolvimento tecnológico, advindo da combinação entre trabalho humano e capital produzido, possibilita substituir o uso dos recursos naturais tornando, portanto, a escassez apenas relativa e os empecilhos passageiros. Qualquer elemento da biosfera que se mostrar limitante ao processo produtivo acabará sendo substituído pelas novas combinações de trabalho, capital produzido e recursos naturais. Desse ponto de vista, conforme comentado por Andrade e Romeiro (2009), uma sociedade será sustentável na medida em que o uso de recursos naturais for compensado pelo aumento dos demais tipos de capital. Veiga (2007, p. 36) afirma que:

\footnotetext{
Uma concepção que acabou sendo batizada de "fraca". Isto porque assume que, no limite, o estoque de recursos naturais possa até ser exaurido, desde que esse declínio seja progressivamente contrabalançado por acréscimos proporcionais, ou mais do que proporcionais, dos outros dois fatores-chave - trabalho e capital produzido - muitas vezes agregados na expressão "capital reprodutível". Ou seja, nessa perspectiva de "sustentabilidade fraca", o que é preciso garantir para as gerações futuras é a capacidade de produzir, e não manter qualquer outro componente mais específico da economia.
}

Esta linha de argumentação é baseada no tecnocentrismo e tem grande convicção no desenvolvimento tecnológico. Seus defensores acreditam que o progresso científico possibilitará substituir recursos naturais mediante inovações, superando as limitações que impedem o crescimento econômico. A confiança no desenvolvimento tecnológico ocorre porque em muitos casos está comprovado que a novas tecnologias permitiram o uso mais eficiente dos recursos, fazendo com que seu emprego seja menor. Loyola (1997, p. 6) complementa afirmando que:

Como podemos apreciar para os economistas ambientais a solução aos problemas da falta de recursos somente é visto como um problema tecnológico (...) se a tecnologia se desenvolve aos níveis requeridos para que os recursos renováveis possam ser trocados pêlos não-renováveis, então o problema ambiental queda ao margem.(sic) 
Assim, seus defensores argumentam que a utilização mais eficiente dos recursos naturais minimizará os eventuais obstáculos advindos da escassez dos mesmos. Portanto, nas palavras de Veiga (2008, p. 123), para esta perspectiva “[...] é o seu fortíssimo otimismo tecnológico que o leva a pregar pela fraqueza da sustentabilidade."

Sachs (2007) traz grande crítica à concepção tecnocêntrica ao afirmar que muitos desastres sociais e ecológicos ocorreram porque muitas técnicas utilizadas pela sociedade envolviam alto grau de ignorância e incerteza quanto aos impactos causados. $\mathrm{O}$ autor afirma ainda que quanto mais poderosa a tecnologia, maior a importância de submetê-la a uma criteriosa avaliação dos prováveis impactos para não acarretar em aumento, no futuro, de custos ambientais e sociais.

Diversos autores também defendem que muitas vezes não é possível fazer a permuta entre os diferentes tipos de capitais, já que os recursos naturais têm características próprias, nem sempre obtidas devido a sua singularidade (CECHIN; VEIGA, 2010). Principalmente quando se trata de recurso natural crítico, isto é, capitais naturais insubstituíveis que geram serviços de suporte a vida e devem receber alta prioridade quanto a sua conservação (O'CONNOR, 2000).

Constanza e Daly (1992 apud ANDRADE; ROMEIRO, 2009) chegam a afirmar que se o capital construído pelo homem fosse um substituto perfeito do capital natural, este também seria um substituto perfeito para o primeiro. Se fosse o caso, não haveria necessidade de produção de capital produzido pelo homem, uma vez que o capital natural já está disponível. Portanto, vários autores defendem a complementaridade, e não a substituição, entre os diferentes tipos de capital, o que implica numa postura de manutenção dos diferentes capitais separadamente. (DENARDIN; SULZBACH, 2002). Tendo isto em vista, propõe-se que as avaliações de sustentabilidade devem estar baseadas não em indicadores monetários, mas em limites e impactos biofísicos. Esta concepção é denominada de sustentabilidade forte, embasamento utilizado pela economia ecológica.

Portanto, diversos pesquisadores acreditam que as resoluções de problemas ambientais atuais exigem mais do que a economia do meio ambiente pode oferecer, por insistirem na abordagem tradicional da precificação e desprezarem aspectos de ordem ecológica dos 
sistemas (LOYOLA, 1997; CAVALCANTI, 2003b; FIGUEROA, 2005; VEIGA; CECHIN 2009).

Nas várias perspectivas de pensamento que existem sobre o desenvolvimento sustentável, podem ser observadas diferentes percepções do mundo natural, dos condicionantes estruturais e dos critérios de racionalidade a serem compartilhados (EGRI; PINFIELD, 1998; SACHS, 2007). Mebratu (1998) busca contribuir para a compreensão destas diferentes abordagens e propõe três grandes grupos de entendimento tendo em vista o interesse dos formuladores. $\mathrm{O}$ autor destaca que cada ponto de vista assume uma posição teórica diferenciada com mecanismos de solução variados.

O primeiro grupo proposto por Mebratu (1998) é formado por abordagens institucionais de desenvolvimento sustentável interessadas nas intervenções e ações de caráter político. $\mathrm{Na}$ concepção do autor inclui-se, nesta perspectiva, o consenso político sobre crescimento sustentável proposto pela Comissão Mundial para o Meio Ambiente e Desenvolvimento apresentada no relatório 'Nosso Futuro Comum'; a ecoeficiência, embasada em interesses comerciais, defendida pela Word Business Council for Sustainable Development e os cuidados primários com o ambiente, na forma de desenvolvimento rural, proposto por ONGs nacionais e internacionais como o International Institute of Environment and Development.

Já o segundo grupo envolve a concepção de desenvolvimento sustentável a partir de abordagens ideológicas interessadas em discutir e atuar sobre os valores humanos. Três correntes de pensamento são classificadas nesta perspectiva: a eco-teologia, proposta por igrejas e congregação e baseada na teoria da libertação; o eco-feminismo, movimento feminista radical fundamentado em valores ginocêntricos e; o eco-socialismo que propõe a igualdade social a partir das ideias marxistas.

O último grupo está estruturado a partir das diferentes abordagens acadêmicas interessadas em produzir conhecimento na perspectiva de um desenvolvimento sustentável. Mebratu (1998) classifica três linhas de pensamento: a economia ecológica que envolve instrumentos de mercado para a internalização das externalidades; a ecologia profunda que propõe o igualitarismo biocêntrico numa perspectiva de reverência e respeito a natureza e; a ecologia social que implica em repensar a hierarquia social numa co-evolução entre natureza e humanidade. 
Desta forma, conforme afirmado por Loyola (1997), não existe uma verdade única a respeito do meio ambiente. Qualquer tipo de política que se formule estará vinculada a uma série de pressupostos que, muitas vezes, tem uma base a ser questionada.

\subsubsection{A Economia Ecológica}

Diversas são as proposições que analisam as relações entre economia e meio ambiente, tendo como premissa a perspectiva de que os sistemas naturais vêm sendo ameaçados pelas intervenções humanas (ANDRADE; ROMEIRO, 2009). Desta forma, não há uma economia da sustentabilidade e inexiste uma teoria única do desenvolvimento ecologicamente equilibrado. Mas, na opinião de Baumgärtner e Quaas (2010), as principais contribuições da economia, nos últimos anos, tendo em vista a ideia geral da sustentabilidade foram:

a) focar o estudo do relacionamento entre o homem e a natureza;

b) orientar as análises econômicas para o futuro a longo prazo;

c) fundamentar as proposições na aspiração de justiça entre os seres humanos das gerações presentes e futuras, bem como entre os seres humanos e a natureza e;

d) entender a eficiência econômica como o não desperdício de bens e serviços naturais.

A abordagem "bioeconômica", perspectiva utilizada no embasamento desta tese, posteriormente denominada de economia ecológica, surge nesta conjunção. Foi motivada pela pouca relevância dos modelos de economia convencional aos atributos biofísicos do processo de desenvolvimento e está alinhada a proposição de sustentabilidade forte. Consolidou-se, enquanto corrente efetiva de pensamento, nos anos de 1980 com a fundação da International Society for Ecological Economics (ISEE) e a criação da revista Ecological Economics (AMAZONAS, 2002). Nas palavras de Cechin e Veiga (2010, p. 2):

\footnotetext{
Uma das principais diferenças entre as duas teorias econômicas, a ecológica e a convencional, está em seus respectivos pontos de partida. Mesmo que existam alguns conceitos comuns, eles são bem secundários se comparados às visões gerais de cada uma sobre a realidade. No fundo, são duas concepções de mundo, pois a convencional enxerga a economia como um todo, e quando chega a considerar a natureza, o meio ambiente, ou a biosfera, eles são entendidos como partes ou setores da macroeconomia (...) Exatamente o inverso da economia ecológica, para a qual a macroeconomia é parte de um todo bem mais amplo, que a envolve e a sustenta.
}

A economia humana é percebida como um subconjunto de um sistema biótico maior. Carvalho et al (2007) afirma que esta perspectiva objetiva devolver o equilíbrio biológico do 
planeta, garantindo a continuidade da humanidade, harmonizando e integrando atividades humanas com aspectos biológicos e físicos dos ecossistemas. Portanto, a economia ecológica tem como uma das principais preocupações a "(in)sustentabilidade ecológica da economia" (ALIER; JUSMET, 2000), o que implica que os sistemas ambientais vitais sejam saudáveis e não entrem em deterioração.

Carrega, desta forma, o propósito de integrar os componentes do sistema econômico com os do sistema natural, procurando compreender seu funcionamento comum e reduzir os danos provocados pelos homens aos sistemas ambientais. Assim, nas palavras de Loyola (1997, p. 9): “[...] ela transcende da sua esfera até outras ciências na procura de um melhor entendimento de quais são os processos biológicos e físicos que permitam entender melhor quais são os limites da sustentabilidade.” Reconhece, para tanto, conceitos e instrumentos da economia, da física e da biologia, buscando utilizá-los de modo integrado e interrelacionados, criando novos modelos e ferramentas (AMAZONAS, 2002).

A economia ecológica propõe que qualquer atividade humana está fundamentada em fluxos de materiais e energias, requerendo uma compreensão biofísica dos processos, o que implica num entendimento termodinâmico das atividades econômicas (CAVALCANTI, 2003b; CECHIN; VEIGA, 2010). Desta forma, conforme descrito por Amazonas (2002, p. 12):

[...] funda-se no princípio de que o funcionamento do sistema econômico, considerado nas escalas temporal e espacial mais amplas, deve ser compreendido tendo-se em vista as condições do mundo biofísico sobre o qual se realiza, uma vez que é deste que derivam a energia e matérias-primas para o próprio funcionamento da economia.

Tal ponto de vista já estava presente no pensamento de Georgescu-Roegen (1971, apud CECHIN; VEIGA, 2010) no livro The entropy law and the economic process, ao afirmar que a mudança qualitativa na economia altera o ambiente de forma irreversível uma vez que no nível físico básico transforma energia "útil” - baixa entropia, em energia "inútil” - alta entropia, isto é, extrai recursos de qualidade de uma fonte natural e despeja resíduos sem qualidade para a economia de volta a natureza. Desta forma, abandona a visão mecânica da economia percebida como isolada da natureza, para uma visão da economia como parte de um sistema vivo. 
Daly (1980), importante pesquisador da área que corrobora com o pensamento seminal proposto por Georgescu-Roegen e argumenta que a economia ecológica está vinculada à articulação de três noções biofísicas fundamentais:

a) a lei da conservação da energia em um sistema fechado, no qual a matéria e a energia só se transformam;

b) a lei da entropia, na qual a matéria e a energia se degradam continuamente de uma forma ordenada para uma forma desordenada e;

c) a possibilidade de gerar mais resíduos do que pode ser assimilado pelos ecossistemas.

As atividades econômicas são percebidas como indissociadas dos ecossistemas, dependendo da sua capacidade de prover recursos e absorver resíduos. Tal fato leva a uma ruptura no paradigma dominante da economia no sentido de que a produção vem acompanhada da geração de desordem. Isto implica numa preocupação dos pesquisadores com o caráter metabólico da economia, ou seja, o processo bioquímico de troca de materiais e energia entre organizações sociais e o meio ambiente natural. O que explica porque para a economia ecológica pode haver crescimento antieconômico, caracterizado como aquele que tem um custo mais alto que o benefício, podendo comprometer o equilíbrio da vida e a sobrevivência. Ideia que, nas palavras de Cechin e Veiga (2010, p. 4) é “[...] sem sentido para qualquer economista tradicional."

Portanto, Cavalcanti (2003b, p. 154) afirma que “[...] a economia ecológica implica uma mudança fundamental na percepção dos problemas de alocação de recursos e de como eles devem ser tratados, do mesmo modo que uma revisão da dinâmica do crescimento econômico." Pode ser considerada, portanto como um novo enfoque sobre as inter-relações entre os sistemas econômicos e o conjunto total dos sistemas físico e social, propondo discutir a ética e os processos culturais centrais para a compreensão do problema da sustentabilidade. É, portanto, uma visão sistêmica e transdisciplinar que transcende o atual paradigma econômico. (FIGUEROA, 2005).

Por ser um campo de conhecimento com a pretensão de juntar economia e ecologia, numa análise conectada, existem diversas abordagens para a incorporação dos princípios biofísicos a partir de variados enfoques econômicos, gerando múltiplas formas de mediação (VEIGA, 2008). 
Diferentes perspectivas buscam a gestão eficiente do capital natural a partir de novos esquemas analíticos operacionais vinculados à economia ecológica. Tipologias variadas para o entendimento da melhor forma de inter-relacionar ecologia e economia surgem nos últimos anos. Amazonas (2002), Romeiro (2003), Müller (2005) são exemplos de pesquisadores que propõem qualificar as propostas adjacentes a economia ecológica.

Veiga (2008, p. 153) afirma que:

No fundo, todas esses esforços de classificação se equivalem, pois as tipologias são sempre dependentes dos critérios escolhidos. E qualquer tentativa de explicar como os economistas estão voltando a dar importância à natureza será necessariamente levada a fazer agrupamentos por critérios que pareçam os mais pertinentes ao autor. (sic)

Acredita-se que, para esta tese, mais importante que compreender a diversidade interior das propostas presentes na economia ecológica é perceber quais são as posições dos autores. Veiga (2010) afirma que surgiram três entendimentos sobre o desenvolvimento econômico sustentável a partir da economia ecológica. A "economia do astronauta", o "decrescimento" e a "condição estacionária", propostas, respectivamente, por três importantes autores seminais: Kenneth Boulding (1910-1993), Nicholas Georgescu-Roegen (1906-1994) e Herman Daly (1938-).

- Boulding (1966) defende que o processo econômico deverá operar num sistema circular auto-renovável em termos materiais, a partir de mudanças tecnológicas, envolvendo apenas o aproveitamento econômico da entrada de energia solar. O fluxo metabólico da humanidade é algo que deve ser minimizado.

- Georgescu-Roegen (1971) baseou suas proposições nas leis da termodinâmica, em especial a leis da entropia, para afirmar que o sistema econômico não pode existir indefinidamente. Tal pensamento está fundamentado na ideia de que, mesmo que a economia não aumente de tamanho, não é realista supor a reciclagem total do que foi dissipado. Por isso, propõe um processo econômico declinante a partir de determinado momento - decrescimento.

- Daly (1980, 1997) é considerado o mais importante economista ecológico da atualidade, propondo a teoria da condição estacionária, na qual a quantidade de recursos da natureza utilizada seria suficiente para manter constante o capital e a população, isto é, a 
obtenção de desenvolvimento sem crescimento material. Os recursos primários só seriam usados para melhorar qualitativamente os bens de capital.

É importante relatar que na economia ecológica as conjecturas, na definição das formas de desenvolvimento da sociedade, variam de um extremo mais próximo da economia tradicional para outro mais vinculado à ecologia. Um grupo de autores desenvolve seu programa de pesquisa em economia ecológica com formulações e ferramentas advindas da economia neoclássica como a preocupação focada na valoração dos bens e serviços ambientais. Já outros pesquisadores propõem abordagens que buscam analisar o sistema econômico a partir da perspectiva ambiental, baseados em conceitos e critérios oriundos da ecologia. Veiga (2007, p. 40) explica esta seara ao afirmar que:

\footnotetext{
O que realmente opõe os economistas ecológicos a todas as outras correntes não é, portanto, o uso de técnicas de valoração. $\mathrm{O}$ verdadeiro pomo da discórdia é o seguinte: recursos naturais e capitais são geralmente complementares e não substitutos. Pensar, como os convencionais, que eles possam se substituir, é contrariar duas leis da termodinâmica.
}

$\mathrm{Na}$ busca por novos entendimentos, ganham destaque propostas para considerar a sustentabilidade do modelo econômico, a partir da biodiversidade e dos ecossistemas (NORTON, 1995). Tal perspectiva defende uma nova racionalidade ecológico-econômica que objetiva trazer o pensamento sistêmico da ecologia para o campo da economia (SOUZA, 2000).

\subsubsection{A Sustentabilidade da Economia a partir da Ecologia}

As palavras economia e ecologia derivam da mesma formação etimológica: a raiz grega oikos que significa "casa". Como "nomia" significa "gerenciamento", economia se traduz por "gerenciamento doméstico". Já "logos" é entendido como "estudo", portanto ecologia é o "estudo da casa ambiental", com ênfase nos padrões de relações entre os organismos e o ambiente (ODUM; ODUM, 2008). Desta forma, ambas deveriam ser disciplinas relacionadas, embora tal perspectiva não aconteça de fato (Quadro 2). 
Quadro 2 - Principais diferenças percebidas entre economia e ecologia

\begin{tabular}{|c|c|c|}
\hline Atributo & Economia & Ecologia \\
\hline Moeda & Dinheiro & Energia \\
\hline Forma de crescimento & Em forma de J forma de S \\
\hline Abordagem tecnológica & Alta tecnologia & Tecnologia apropriada \\
\hline Serviços do sistema & Serviços prestados pelo capital & Serviços prestados pelo capital \\
& econômico & Circular (reciclar) \\
\hline Uso do recurso & Linear (descartar) & Capacidade de suporte \\
\hline Regra do sistema & Expansão exponencial & Sustentabilidade e estabilidade \\
\hline Meta futurística & Exploração e expansão & .
\end{tabular}

FONTE: Adaptado de ODUM; BARRETT, 2008, p.2.

A ecologia é um ramo da ciência reconhecido há mais de 100 anos, sendo que inicialmente era subdivida em linhas taxonômicas separadas - ecologia vegetal e ecologia animal. Mas, vários estudos posteriores ajudaram a definir um campo unificado de ecologia geral.

Esta área de conhecimento tem como objeto os níveis de sistema para além dos organismos, sendo uma abordagem holística para a resolução de problemas, conforme pode ser visualizada na Figura 1. Um sistema ecológico ou ecossistema “[...] é qualquer unidade que inclui todos os organismos (a comunidade biótica) em uma dada área interagindo com o ambiente físico de modo que um fluxo de energia leve a estruturas bióticas claramente definidas e a ciclagem de materiais entre componentes vivos e não vivos.”(ODUM; BARRETT, 2008, p. 18). 


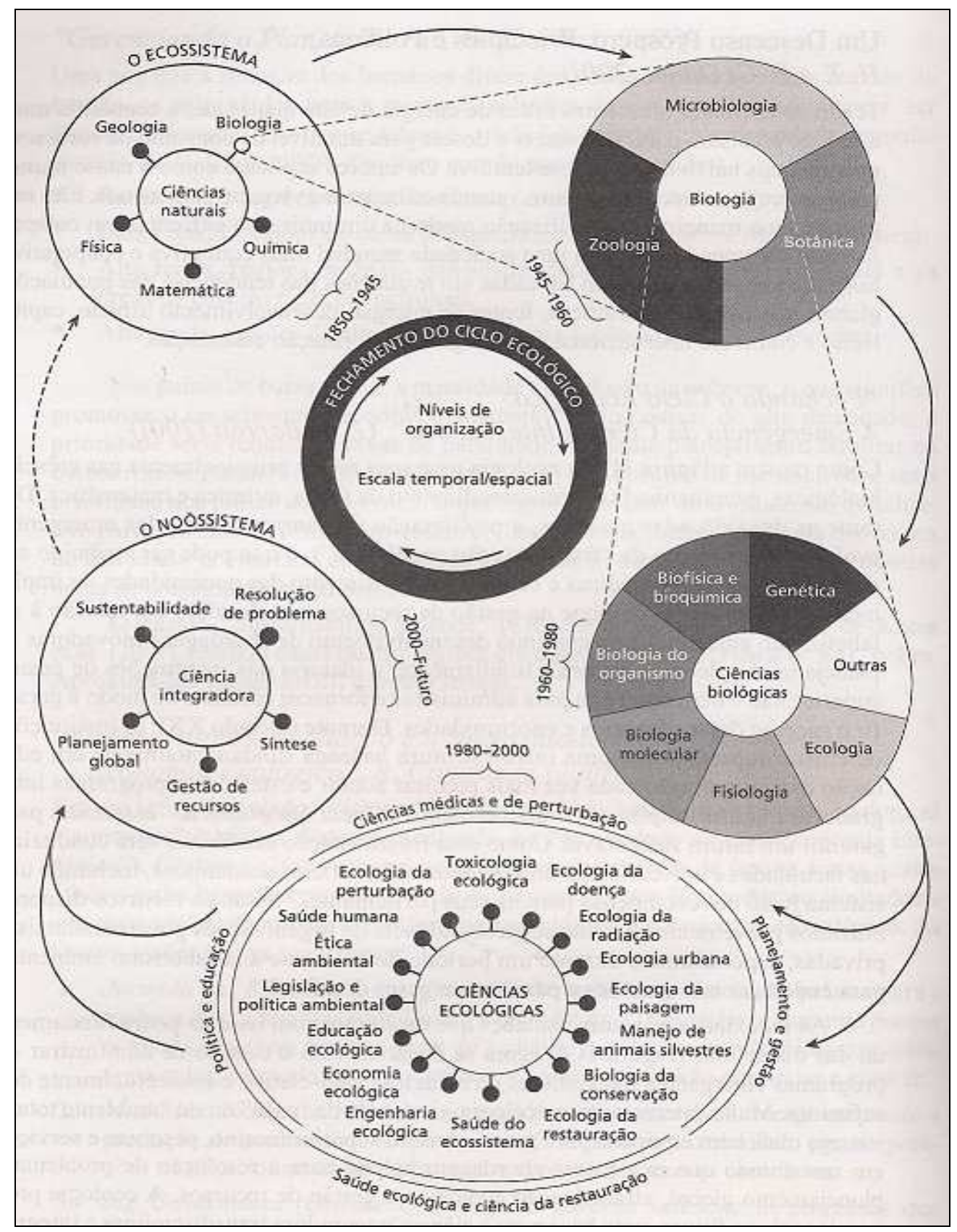

Figura 1 - Desenvolvimento da ecologia enquanto ramo de conhecimento FONTE: Adaptado de ODUM; BARRETT, 2008, p.476.

Assim, com a consolidação da economia ecológica amplia-se, nos últimos anos, o debate para compreender de que maneira os processos ecológicos condicionam o processo de produção de bens e serviços valorados economicamente (CAVALCANTI, 2003b). Muitos autores já propõem que a ecologia pode ajudar resolver problemas econômicos, a partir da aproximação ecológica (ZACCARELLI et al, 1980; CONSTANZA, 1991; DALY; TOWNSEND, 1993; HAWKEN, 1993; NORTON, 1995; CAPRA, 1997, 2002, 2006; HAWKEN et al, 2000; LOYOLA, 1997; LASZLO, 2001; ODUM; ODUM, 2001; CAVALCANTI, 2003b; 
MUELLER, 2007; ODUM; BARRETT, 2008; SACHS, 2007; ANDRADE; ROMEIRA, 2009).

Desta forma, não só ecólogos, mas também cientistas físicos e sociais começaram a considerar a ideia de que a sociedade humana e o ambiente natural possuem propriedades sistêmicas convergentes. Segundo Morgan (1996) o pensamento biológico tem influenciado a teoria organizacional e social desde o século XIX através de Spencer, Durkheim e RadcliffeBrown. Neste sentido, Veiga (2009, p.3) enfatiza que: "Sem mudar o arcabouço conceitual, não é possível passar da escala individual para a escala da humanidade, e do horizonte temporal pertinente ao indivíduo para o horizonte pertinente à humanidade.”

Müeller (2007) é simpatizante deste ponto de vista e afirma que ao observar as relações entre o capital natural e o sistema econômico pode-se perceber que este último, considerado um organismo vivo e complexo, não atua de maneira independente do sistema natural que o sustenta. Morgan (1996, p. 252), ao elaborar as organizações como fluxo e transformação, reforça tal pensamento destacando que: "A longo prazo, sobrevivência só pode ser sobrevivência com o ambiente e nunca sobrevivência contra o ambiente ou contexto no qual se está operando."

Capra $^{3}$ (1997, 2002, 2006) é um importante autor que defende essa perspectiva, pois entende o mundo como uma teia de fenômenos inter-relacionados e interdependentes e busca compreender as coisas sistemicamente. $\mathrm{O}$ autor argumenta que existem propriedades sistêmicas na forma de um padrão comum de organização que estão presentes nos ecossistemas e também precisam ser inseridas nas comunidades humanas para que sejam sustentáveis, possibilitando a continuidade da vida. Para ele, a sustentabilidade não é uma propriedade individual, mas uma característica que advém da forma como ocorrem os relacionamentos entre os humanos e o meio ambiente.

\footnotetext{
${ }^{3}$ Fritjot Capra é austríaco com doutorado em física teórica pela Universidade de Viena (1966) e passou seus dois primeiros anos de pesquisas de pós-doutorado na Universidade de Paris (1966-1968). Realizou pesquisas em física de partículas na University of California em Santa Cruz (1968-1970), no Stanford Linear Accelerator Center (1970), no Imperial College da University of London (1971-1974) e no Lawrence Berkeley Laboratory da University of California (1975-1988). Ele também foi professor da University of California em Santa Cruz e em Berkeley, além da San Francisco State University. Considera-se teórico de sistemas e, atualmente, faz parte do corpo docente da Schumacher College, um centro internacional de estudos ecológicos na Inglaterra.
} 
O estudioso defende que, embora não seja possível aprender sobre valores e fraquezas humanas a partir dos ecossistemas, pode-se e deve-se aprender com a natureza sobre como viver de maneira sustentável. Ser sustentável, para Capra (1997, 2002, 2006), não implica num estudo imutável e estático das coisas, mas num processo dinâmico de coevolução. Discutir a sustentabilidade e sociedades sustentáveis requer repensar as instituições sociais e transpor as diferenças entre os projetos humanos e os sistemas ecológicos presentes na natureza.

\begin{abstract}
A chave de uma definição operativa de sustentabilidade ecológica é a percepção de que não precisamos inventar comunidades humanas sustentáveis a partir do nada; podemos moldá-las segundo os ecossistemas naturais, que são comunidades sustentáveis de vegetais, animais e microorganismos. (CAPRA, 2002, p. 238).
\end{abstract}

Capra compreende a sustentabilidade como um fenômeno que será alcançado dentro de um contexto, definido pela forma de interação com outros indivíduos e o sistema natural. Propõe, portanto, estruturar as comunidades humanas segundo os modelos de organização dos ecossistemas naturais, isto é, características padrão de organização da natureza. Afirma ainda que: "Precisamos aplicar nossos conhecimentos ecológicos a uma reformulação fundamental de nossas tecnologias e instituições sociais, de modo a transpor o abismo que atualmente separa as criações do ser humano e dos sistemas ecologicamente sustentáveis da natureza." (CAPRA, 2002, p. 241).

Para tanto, sugere que princípios básicos da ecologia estejam presentes nas instituições sociais e desenvolve uma estrutura conceitual para configuração do padrão das relações, denominando-os de princípios ecológicos. Princípios ecológicos também chamados pelo autor de princípios básicos da ecologia, princípios da comunidade e princípios da sustentabilidade referem-se às características presentes em todos os sistemas vivos, sendo a base da organização e suporte dos ecossistemas naturais e, por consequência, da sustentabilidade dos mesmos. $\mathrm{O}$ autor acredita que a sobrevivência da humanidade dependerá da capacidade do homem de entender os princípios básicos da ecologia e viver em conformidade com eles (CAPRA, 1997).

Laszlo (2001) também acredita nessa perspectiva e diz que é preciso garantir que as tecnologias humanas sejam coerentes com as tecnologias do mundo natural, afirmando que: 
(...) precisamos trabalhar "no nível da espécie", porque nossos problema estão além de qualquer solução cultural existente. Temos de retornar ao nosso código genético. Nossos problemas estão no nível da espécie e no nível interespécie. Isso é claro em todos os aspectos do humano. Quanto à economia, não precisamos apenas de uma economia da nação ou do globo, mas de uma economia da espécie e interespécie. (p. 198).

Entretanto, Capra (1997, 2002) enfatiza que os ecossistemas podem ser utilizados para subsidiar o processo de desenvolvimento de sociedades sustentáveis apenas no que se refere ao padrão de organização. O estudo da estrutura, envolvendo descrição dos componentes físicos e composições químicas, não é entendido como uma proposta interessante para compreender a sustentabilidade em sociedades humanas, chegando a afirmar que: "[...] embora a compreensão da organização das redes biológicas possa nos ajudar a compreender redes sociais, não devemos ter a intenção de transferir para o domínio social nossa compreensão da estrutura material das redes biológicas.” (CAPRA, 1997, p. 93).

É interessante observar que diversos autores corroboram com as ideias presentes nos princípios ecológicos estruturados por Capra, mesmo que não os elenque com esta denominação. Cavalcanti (2003a) é um destes teóricos e afirma que: “[...] a sociedade deve estar de tal modo organizada que sua troca de matéria e energia com a natureza não viole certos postulados." (p. 18).

Em três de suas obras, Capra concentra-se em descrever quais são os princípios ecológicos que devem ser transpostos para a sociedade e utilizados como diretrizes na estruturação de comunidades humanas sustentáveis. Observa-se, a partir da análise das obras, que a lista de princípios ecológicos sofreu alterações, tornando-se maior ao longo do tempo, conforme pode ser visualizado no Quadro 3.

Quadro 3 - Princípios ecológicos elencados por Capra

\begin{tabular}{|c|c|c|}
\hline \multicolumn{3}{|c|}{ Princípios Ecológicos } \\
\hline $\begin{array}{c}\text { Obra: A Teia da Vida } \\
\text { (1996) }\end{array}$ & $\begin{array}{c}\text { Obra: Conexões Ocultas } \\
(2002)\end{array}$ & $\begin{array}{c}\text { Obra: Alfabetização Ecológica } \\
\qquad(2005)\end{array}$ \\
\hline $\begin{array}{ll}\text { - } & \text { Interdependência } \\
\text { - } & \text { Reciclagem } \\
\text { - } & \text { Parceria } \\
\text { - } & \text { Diversidade } \\
\text { Flexibilidade }\end{array}$ & $\begin{array}{ll}\text { - } & \text { Redes } \\
\text { - } & \text { Ciclos } \\
\text { - } & \text { Parceria } \\
\text { - } & \text { Diversidade } \\
\text { - } & \text { Energia Solar } \\
\text { - } & \text { Equilíbrio Dinâmico }\end{array}$ & $\begin{array}{ll}\text { - } & \text { Redes } \\
\text { - } & \text { Ciclos } \\
\text { - } & \text { Sistemas Aninhados } \\
\text { - } & \text { Interdependência } \\
\text { - } & \text { Diversidade } \\
\text { - } & \text { Equilíbrio Dinâmico } \\
\text { - } & \text { Desenvolvimento } \\
\text { - } & \text { Fluxos }\end{array}$ \\
\hline
\end{tabular}

FONTE: a autora, baseada nas obras de Capra (1997, 2002, 2006). 
O princípio ecológico denominado de redes, considerando o padrão básico da vida, é compreendido por Capra como a interligação e dependência mútua de um organismo para com outros devido à vasta rede de relações existentes. Um padrão de atuação em redes sugere a presença de cooperação generalizada entre os indivíduos de um ecossistema, e arranjos de cooperação. Os relacionamentos simbióticos na forma de redes são descritos pelo autor como presentes desde a criação das primeiras células nucleadas, há mais de dois bilhões de anos. $\mathrm{O}$ autor desta ainda que:

O padrão em redes (network pattern), especificamente, é um dos padrões de organização mais básicos de todos os sistemas vivos. Em todos os níveis de vida - desde as redes metabólicas das células até as teias alimentares dos ecossistemas -, os componentes e os processos dos sistemas vivos se interligam em forma de rede. (CAPRA, 2002, p. 93).

Para Capra (1997), entender as redes ecológicas significa entender relações e interdependências existentes entre os membros de uma comunidade ecológica, o que implica numa mudança de percepção "das partes para o todo, de objetos para relações, de conteúdo para padrão.” (p. 232). Desta forma, o autor defende que todos os sistemas se comunicam uns com os outros, existindo redes dentro de redes, o que também é apresentado por Odum e Barrett (2008). Isto leva à existência de sistemas aninhados reforçando que os mesmos princípios básicos de organização estão presentes em todos os níveis da escala de complexidade.

Desta forma, tanto Capra (1997) quanto Odum e Barrett (2008) e Covey (1989) concordam que não há limites de separação entre os indivíduos de uma sociedade, mas limites de identidade. Isto é afirmado uma vez que quanto mais estruturada a rede, mais recursos são partilhados e mais limites entre os sistemas são transpostos. Portanto, nenhum organismo individual pode existir isoladamente, por isso a sustentabilidade das diferentes populações e de todo o ecossistema são interdependentes.

O ciclo, outro padrão de relação presente nos sistema natural, advém da percepção sobre a natureza cíclica dos processos ecológicos em que ecossistemas como um todo permanecem livres de resíduos devido aos laços de realimentação.

Todos os organismos vivos, para permanecerem vivos, têm de alimentar-se de fluxos contínuos de matéria e energia tiradas do ambiente em que vivem; e todos os organismos vivos produzem resíduos continuamente. Entretanto, um ecossistema, considerado em seu todo não gera resíduo 
nenhum, pois os resíduos de uma espécie são os alimentos de outra. Assim, a matéria circula continuamente dentro da teia da vida. (CAPRA, 2002, p. 239).

A lição para as comunidades humanas está evidente nas palavras do próprio autor: "Os padrões sustentáveis de produção e de consumo precisam ser cíclicos, imitando os processos cíclicos da natureza.” (CAPRA, 1997, p. 232). Tal perspectiva também já tinha sido defendida por Boulding (1966) e mais recentemente por Hawken (1993), Hawken et al (2000), Erickson (2002), Müeller (2007), bem como Sachs (2007, p. 82), que afirma:

O ciclo ecológico apresenta-se aqui como um verdadeiro modelo para o sistema econômico. Não se trata, como pretendem alguns, de salvaguardar a todo custo os ecossistemas naturais, mas de conceber os sistemas artificiais criados pelo homem como verdadeiros ecossistemas e de zelar para que a inserção dos mesmos nos ciclos ecológicos gerais se faça de forma a não alterar estes últimos.

Assim, em última instância, numa sociedade sustentável, a matéria e a energia devem estar circulando continuamente entre os diferentes indivíduos, num processo ininterrupto de reciclagem, de modo que os fluxos de produção e consumo sejam fechados dentro da sociedade ou ajustados aos ciclos naturais. E, ainda, para alcançar tal nível de desenvolvimento, os autores defendem que se deve tirar o máximo proveito do fluxo de energia solar e outras formas de energia que são renováveis e benignas ao meio ambiente, como a eletricidade fotovoltaica, energia eólica, hidrelétrica e biomassa.

O equilíbrio dinâmico advém de um padrão de organização, sendo, portanto, um outro princípio ecológico que surge em consequência dos múltipos laços de realimentação, colaborando para a autorregulação e auto-organização do sistema. Capra (1997, p. 234) afirma que o sistema social é uma organização semelhante ao indivíduo, necessitando de comunicação com o meio externo para se manter coeso, portanto, “[...] quanto mais variáveis forem mantidas flutuando, mais dinâmico será o sistema, maior será a sua flexibilidade e maior será sua capacidade para se adaptar as condições mutáveis.” Odum e Barrett (2008) corroboram com esta característica ecológica ao afirmarem que os mecanismos de retroalimentação, tanto negativos quanto positivos, são fundamentais para um desenvolvimento ordenado e para a alta qualidade das comunidades humanas e bióticas.

A diversidade é apresentada como uma nova característica ecológica vinculada à estrutura de rede do sistema e, portanto, a riqueza da complexidade das conexões de rede. Capra (2006) destaca que a “[...] diversidade significa muitas relações e muitas diferentes abordagens." (p. 
53). Nesta mesma obra, Capra também enfatiza que nas comunidades humanas a diversidade étnica e cultural pode exercer o mesmo papel que biodiversidade exerce num ecossistema.

Para o autor, um ecossistema diversificado é também mais flexível, uma vez que contém funções ecológicas sobrepostas que podem substituir umas as outras melhorando a sua capacidade de reorganização, recuperação e sobrevivência. Ele ainda desta que a diversidade é uma vantagem estratégia quando houver diversos indivíduos integrados numa teia de relações.

Os princípios ecológicos propostos por Capra $(1997,2002,2006)$ estão em consonância com as ideias apresentadas por Laszlo (2001, p. 198) que afirma: “As espécies humanas precisam desenvolver relações econômicas recíprocas com as outras formas de vida, oferecendo um padrão sustentável de apoio mútuo, como ocorre com outros sistemas vivos”. Estes entendimentos trazem uma nova perspectiva para o estudo da sustentabilidade em instituições sociais, o que inclui as empresas, por envolver a concepção de que o sistema humano e o sistema ambiental são integrados e implicam num processo de adaptação mútua e de coevolução.

Boeira (2002, p. 86), ao analisar as ideias de Capra, afirma que: "Trata-se de uma travessia trans-disciplinar e sistêmica entre ciências naturais e humanas ou sociais, uma reorientação paradigmática das mesmas.” Entretanto, Cavalcanti (2003a, p. 20) destaca que exatamente pela abordagem holística trazida "[...] levar a cabo o empreendimento de integração dos princípios ecológicos e limites físicos no formalismo dos modelos da economia compreende não poucas dificuldades."

Layrargues (2003) rebate de modo incisivo os princípios ecológicos descritos e a perspectiva da ecologia subsidiando proposições econômicas. Afirma que a proposta de Capra submete o social ao biológico com indevido uso do determinismo biológico. Ele defende que o autor em suas proposições superdimensiona a importância das relações ecológicas positivas criando uma carga valorativa de virtuosidade da natureza.

Layrargues (2003) enfatiza que Capra ignorou o caráter bidimensional das relações ecológicas e as interações negativas que também estão presentes na natureza como a desigualdade, a competição, a violência, a dominação e a hierarquia. Portanto, ele conclui que “[...] esse 
modelo comporta a negação da condição de naturalidade do caráter conflituoso tanto na natureza como na sociedade, como se o conflito na sociedade fosse uma aberração e como se fosse inexistente na natureza." (p. 9).

Já Boeira (2002), ao analisar as ideias do mesmo autor, afirma que "[...] Capra mostra que os conflitos acontecem num contexto de complementação e cooperação." (p.3). Nas palavras do próprio autor "[...] ambos os lados de um conflito podem ser importantes, dependendo do contexto, e que as contradições no âmbito de uma comunidade são sinais de sua diversidade e de sua vitalidade e, deste modo, contribuem para a viabilidade do sistema." (CAPRA, 1997, p. 235).

A ideia do conflito também está contemplada quando o autor fala sobre tensão:

\begin{abstract}
A falta de flexibilidade se manifesta como tensão. Em particular, haverá tensão quando uma ou mais variáveis do sistema forem empurradas até seus valores extremos, o que induzirá uma rigidez intensificada em todo o sistema. A tensão temporária é um aspecto essencial da vida, mas a tensão prolongada é nociva e destrutiva para o sistema. (CAPRA, 1997, 234).
\end{abstract}

Entretanto, o próprio Capra destaca que a ciência nunca fornece uma compreensão completa e definitiva e afirma que:

Independentemente de quantas conexões levamos em conta na nossa descrição científica de um fenômeno, seremos sempre forçados a deixar outras de fora. Portanto, os cientistas nunca podem lidar com a verdade, no sentido de correspondência precisa entre a descrição e o fenômeno descrito. Na ciência, sempre lidamos com descrições limitadas e aproximadas da realidade. (CAPRA, 1997, p. 50).

Essa afirmação de Capra ajuda a compreender porque o autor se conteve em apresentar as características ecológicas na forma de ideias elementares, isto é, princípios básicos que a natureza fez evoluir para sustentar a vida no planeta. Os fundamentos de organização dos ecossistemas apresentados nas diferentes obras, mesmo sem detalhamento operacional, já possibilitam sua compreensão conceitual e a elaboração intelectual para a transposição da sustentabilidade ecológica à realidade das instituições sociais. 


\subsection{O Subsídio das Abordagens Filosóficas para a Compreensão da Sustentabilidade}

Jonas (1979) afirma que a violação da natureza e a civilização do homem caminham juntas, uma vez que as interferências no ambiente natural eram percebidas, pelo próprio homem, como superficiais e impotentes para prejudicar o equilíbrio assentado. Todavia, a concepção de mundo holística que compreende o indivíduo, a sociedade, e a natureza como um todo integrado e não como uma coleção de partes dissociadas, levou a ampliação da consciência social das pessoas com a Terra. Interligação e interdependência, enquanto forma de raciocínio, ganharam força na explicação de variados fenômenos (CAPRA, 1997).

Iniciou-se uma mudança de visão na ciência e na sociedade advinda da transformação paradigmática. Sachs (2007, p. 54) complementa este pensamento ao afirmar que:

\footnotetext{
Depois do anti-romance e da contracultura, o não-crescimento. Três sintomas, certamente bem diferentes, do requestionamento de valores por uma sociedade à procura de novos referenciais ideológicos para problemas que permaneceram insolúveis, apesar dos progressos espetaculares do crescimento material, ou que surgiram na seqüência deste último [...]
}

Tais fatos questionam a conduta humana assumida nos últimos séculos e ampliam o entendimento da ética para incluir o ambiente de suporte da vida. Leopold, considerado o precursor da ecologia profunda, numa coletânea de ensaios publicada em 1949 sob o título $A$ Sand Country Almanac, já sugeria a ampliação do escopo da ética ao longo do tempo. O autor afirma que o desenvolvimento da religião possibilitou o desenvolvimento de uma ética de humano para humano. Posteriormente as ideias de democracia induziram a uma ética humana para a sociedade e, finalmente, a percepção do homem integrado a um contexto ambiental leva a um relacionamento ético entre os seres humanos e seu ambiente. Ferry (1994) complementa tal pensamento ao afirmar que:

\footnotetext{
(...) teria chegado a hora dos direitos da natureza, depois dos direitos das crianças, das mulheres, dos negros, dos índios, até mesmo dos presos, dos loucos ou dos embriões [no âmbito da pesquisa médica, senão no das legislações sobre o aborto, células-tronco etc]. Em suma, trata-se de sugerir que o que parecia impensável numa dada época, converteu-se hoje em evidência (p.15 - 16).
}

Portanto, uma nova tradição de pensamento filosófico está sendo construído uma vez que, para Jonas (1979, p. 35), “a significação ética dizia respeito ao relacionamento direto de homem com homem, inclusive o de cada homem consigo mesmo; toda ética tradicional é antropocêntrica". A perspectiva ecológico-filosófica, ampliada nos últimos anos, é 
revolucionária, pois visa outra relação entre as pessoas e o planeta. Laszlo (2001, p. 92) apresenta uma nova possível diretriz da ética universal que diz: "Viva de maneira que permita ao outros também viver". Sendo que estes "outros" incluem, além dos seres humanos, todas as coisas que formam a teia da vida no planeta. Portanto, a comunidade moral envolve formas de vida não humanas, e seres inanimados, perante os quais os homens têm deveres morais.

A crítica ao antropocentrismo já estava presente em textos do século XVI, quando se advogava o direito intrínseco dos animais e até mesmo de seres inanimados (CAMPOS, 2008). Mas, por muitos séculos, a preocupação com o meio ambiente existia unicamente em função do bem-estar e privilégio do próprio homem. A natureza não-humana ficou excluída da esfera da moralidade, e os animais eram vistos como seres significativamente diferentes e inferiores aos humanos (LASZLO, 2001). Neste sentido, Jonas (1979, p. 40) complementa afirmando que: "Enquanto for o destino do homem, dependente da situação da natureza, a principal razão que torna o interesse na manutenção da natureza um interesse moral, ainda se mantém a orientação antropocêntrica de toda ética clássica."

Só no final do século passado, ampliou-se uma nova ética ambiental na relação pessoa/planeta envolvendo um paradigma ecocêntrico, no qual a preservação do ambiente natural deve ser praticada em função dele mesmo e não do homem em si (CAMPOS, 2008; EGRI; PINFIELD, 1998). A hipótese de biofilia por Wilson (1984) e a hipótese de Gaia proposta por Lovelock (1979) reforçam esta perspectiva ao mostrarem que há um estreito entrosamento entre as partes vivas e não-vivas do planeta. Portanto, amplia a compreensão da vida de maneira sistêmica, integrando áreas do conhecimento e disciplinas diversas, cujos profissionais não estão acostumados a se comunicarem.

Neste novo paradigma, a relação centrada no verticalismo, no qual alguém domina, é substituída por uma interação na forma de rede, que implica em horizontalidade e paridade, reconhecendo a interdependência de todos os fenômenos e processos. Entretanto, Laszlo (2001) destaca que:

Como não compreendemos adequadamente a Terra, quer por nossas tradições espirituais ou pelas científicas, o humano tornou-se um apêndice ou um intruso. Essa situação nos agrada, porque nos permite evitar o problema de uma presença integrada à Terra. Essa atitude nos impede de considerar a Terra como uma sociedade unida, com relações éticas determinadas basicamente pelo bem-estar de toda a comunidade da Terra. (p. 198). 
Esta abordagem reflexiva é denominada de Ecologia Profunda e foi criada na década de 1970 pelo filósofo norueguês Arnes Naess a partir do pensamento filosófico proposto por Leopold (1949). A ecologia profunda propõe a unidade do homem com a natureza, em oposição ao que Naess (1973) denominou de ecologia 'superficial' ou 'rasa - perspectiva antropocêntrica-, conforme apresentado no Quadro 4.

Segue as principais premissas da ecologia profunda sintetizadas por Devall (2001):

a) $\mathrm{O}$ bem-estar e a vida humana e não-humana na Terra têm valor em si mesmos, independentes da sua utilidade para propósitos humanos.

b) A riqueza e diversidade das formas de vida também são valores em si mesmos.

c) Os seres humanos não têm direito de reduzir esta riqueza e diversidade, exceto para satisfazer necessidades vitais.

d) A vida e cultura humana são compatíveis com a diminuição da população humana.

e) A atual interferência humana no sistema natural é excessiva e a situação está piorando rapidamente.

f) Políticas devem ser alteradas, o que envolve mudanças nas estruturas econômicas, tecnológicas e ideológicas.

g) A mudança ideológica requer que se aprecie a qualidade de vida ao invés de aderir a um o padrão de vida mais elevado.

Quadro 4 - Diferenças entre a ecologia rasa e a ecologia profunda

\begin{tabular}{|c|c|}
\hline Ecologia Rasa & Ecologia Profunda \\
\hline Domínio da Natureza & Harmonia com a Natureza \\
\hline $\begin{array}{l}\text { Ambiente natural como recurso para os } \\
\text { seres humanos. }\end{array}$ & Toda a Natureza tem valor intrínseco. \\
\hline $\begin{array}{l}\text { Seres humanos são superiores aos demais } \\
\text { seres vivos. }\end{array}$ & Igualdade entre as diferentes espécies. \\
\hline $\begin{array}{l}\text { Crescimento econômico e material como base para o } \\
\text { crescimento humano. }\end{array}$ & $\begin{array}{c}\text { Objetivos materiais a serviço de objetivos maiores de } \\
\text { auto-realização. }\end{array}$ \\
\hline Crença em amplas reservas de recursos. & Planeta tem recursos limitados. \\
\hline $\begin{array}{l}\text { Progresso e soluções baseados em } \\
\text { alta tecnologia. }\end{array}$ & $\begin{array}{l}\text { Tecnologia apropriada e ciência } \\
\text { não dominante. }\end{array}$ \\
\hline Consumismo. & Fazendo com o necessário e reciclando. \\
\hline Comunidade nacional centralizada. & $\begin{array}{l}\text { Biorregiões e reconhecimento de tradições } \\
\text { das minorias. }\end{array}$ \\
\hline
\end{tabular}

FONTE: NAESS, 1973, p.100.

A ecologia profunda está alicerçada em valores ecocêntricos, centrados na Terra. Admite, portanto, o valor inerente da vida não-humana uma vez que os seres vivos e suas instituições sociais são membros de comunidades ecológicas numa perspectiva de interdependência. 
Capra (1987, 2004 e 2005) propõe o seu pensamento embasado na concepção da ecologia profunda que, nas palavras do próprio autor, “[...] vê o mundo não como uma coleção de objetos isolados, mas como uma rede de fenômenos que estão fundamentalmente interconectados e são interdependentes." (CAPRA, 1997, p. 25).

Esta linha de pensamento reconhece que os seres humanos estão inseridos nos processos cíclicos da natureza, sendo dependentes e inseparáveis deles (AVELINE, 1999). Tal fato traz uma nova ética para o homem.

No contexto da globalização, há duas grandes comunidades as quais todos nós pertencemos: todos somos membros da raça humana e todos fazemos parte da biosfera global. Somos moradores do oikos, da 'casa Terra', que é a raiz grega da palavra 'ecologia', e devemos nos comportar como se comportam os outros moradores dessa casa - as plantas, os animais e os microorganismos que constituem a vasta rede de relações que chamamos de teia da vida. (CAPRA, 2002, p. 223).

Desta forma, a ecologia profunda questiona os fundamentos e crenças em relação ao mundo e à vida modernos - orientados para o materialismo e o crescimento - e propõe uma mudança nas percepções e valores humanos (CAPRA, 1997). A ética deve incluir valores ambientais aliados a valores humanos e, conforme destacado por Odum e Barrett (2008), juntar num holismo coextensivo os três "es" - ecologia, economia e ética.

Essa percepção de integração e unidade do homem com a natureza induziu novos paradigmas científicos e um novo aparato conceitual. Contingência, complexidade, visão sistêmica, recursividade, conjunção e interdisciplinaridade são exemplos de princípios filosóficos científicos emergentes desses pensamentos (ROHDE, 2003).

Pode-se dizer, portanto, que a ecologia profunda se aproxima da perspectiva holística, palavra construída a partir da raiz grega holos, que significa completo, inteiro, todo (HALL; LINDZEY, 1973). O objeto de análise é percebido dentro de um todo mais amplo, aproximando vários campos de estudo e áreas do conhecimento (D’AMBROSIO, 1991).

Bateson (1972), Lovelock (1979), Maturana e Varela (1980) e Sheldrake (1981) são exemplos de pesquisadores que, assim como Capra (1997, 2002), produziram trabalhos variados utilizando-se das ideias da ecologia profunda e deram legitimidade científica a essa 
perspectiva. Entidades como o Greenpeace e o Earth First, além de filósofos como Jonas (1979) e Laszlo (2001) também partilham dessa perspectiva de mundo.

Veiga (2008) destaca que um dos principais problemas que o pensamento ecológico-filosófico trouxe à humanidade refere-se à qualidade de vida de uma geração à outra, e particularmente a repartição do dote da humanidade entre todas as gerações. Para Jonas (1979), tal reflexão faz sentido uma vez que o universo moral consiste nos contemporâneos e, se uma ação é "boa" ou "má", tal julgamento é decidido no interior de um contexto de curto prazo.

Portanto, a preocupação com as futuras gerações, na opinião de Sachs (2007), implica numa dupla dimensão ética: as finalidades sociais do desenvolvimento e o cuidado com o futuro. Todavia, o mesmo autor destaca que:

\footnotetext{
Este alto grau de responsabilidade e de consciência ecológica está longe de ter sido atingido, especialmente porque a solidariedade com as gerações futuras tem pouco significado para as maiorias desvalidas das nossas sociedades contemporâneas, as quais têm boas razoes para reclamar, de saída, mais solidariedade no seio da geração atual. (SACHS, 2007, p. 88).
}

A economia, como uma atividade social, não pode estar desvinculada das concepções morais presentes na sociedade (CASTELLS, 2007). Isto ajuda a explicar porque nos últimos anos está havendo um questionamento sobre a forma clássica de gerenciamento das empresas. Iniciou-se uma revisão das crenças fundamentais das pessoas e do processo decisório das organizações, reestruturando o capitalismo para proporcionar a sustentabilidade do planeta (CAPRA, 2002). E, segundo Elkington (2001, p.4), o pior bloqueio que os líderes atuais podem ter é acreditar que a sustentabilidade é uma nova forma de doutrina, ao invés de uma nova forma de valores.

\subsection{Responsabilidade Social e Sustentabilidade do Negócio}

Desde a Revolução Industrial, as empresas vêm externalizando ao máximo possível os custos econômicos, sociais e ambientais advindos das suas atividades. Tal situação levou, na opinião de Elkington (2001), a doenças sociais como a escravidão, o trabalho infantil, a devastação de florestas e a poluição. 
Essas implicações, ao longo do tempo, ampliaram a percepção de diferentes agentes sociais de que as iniciativas em negócios têm um impacto sobre o lucro e sobre o mundo (SAVITZ, 2007). Claro et al (2008) destacam que hoje a sociedade tem preocupações que não existiam em qualquer outra época, como a proteção ecológica, defesa do consumidor, qualidade dos produtos, práticas trabalhistas, direitos humanos e outras questões sociais. Consequentemente, intensificou-se as expectativas a respeito do comportamento e da conduta organizacional apropriada.

Kotler et al (2010, p. 4) enfatizam que:

Cada vez mais os consumidores estão em busca de soluções para satisfazer seu anseio de transformar o mundo globalizado num mundo melhor. Em um mundo confuso, eles buscam empresas que abordem suas mais profundas necessidades de justiça social, econômica e ambiental em sua missão, visão e valores. Buscam não apenas satisfação funcional e emocional, mas também satisfação espiritual, nos produtos e serviços que escolhem.

Pode-se afirmar, portanto, que as relações entre a sociedade e as empresas baseiam-se num contexto social que vai evoluindo conforme as mudanças sociais e as consequentes expectativas da sociedade (BORGER; KRUGLIANSKAS, 2002). No atual contexto, a gestão empresarial que responde apenas aos interesses dos acionistas revela-se insuficiente.

Barbieri e Cajazeira (2009) destacam que o papel social da empresa centrado na função econômica como geradora de lucros, salários e impostos já não é mais suficiente para orientar os negócios diante dos novos valores requeridos pela sociedade. Kotler et al (2010, p. 15) enfatizam que hoje "[...] as empresas estão competindo para ser vistas como propiciadoras de continuidade, conexão e direção".

Fomenta-se, portanto, a responsabilidade das empresas pelas consequências de suas operações, o que inclui os impactos gerados diretamente, bem como as externalidades que envolvem a cadeia produtiva e o ciclo de vida dos produtos e serviços (BORGER, 2004; FURTADO, 2004). Neste sentido Savitz (2007, p.7) afirma que: "Cada vez mais, os negócios são considerados responsáveis não só por suas próprias atividades, mas também pelas dos fornecedores, pelas comunidades em que atuam e pelas pessoas que usam seus produtos."

Os gestores são induzidos a procurar uma imagem legítima, de modo que muitas empresas têm se dedicado a estratégias até pouco tempo atrás desnecessárias e negligenciadas 
(KREITLON; QUINTELLA, 2001). Isso desafia as empresa a minimizar os resíduos de suas operações e adotar uma postura de interação e diálogo com diferentes públicos de relacionamento, buscando novas soluções economicamente viáveis para os problemas sociais e ambientais (HART, 2006).

Cresce a busca por um novo modelo de gestão que permite balancear as exigências por baixo custo, alto padrão de qualidade e incremento da competitividade com a análise de questões éticas, sociais e ambientais, tornando a empresa mais consistente com as reivindicações e expectativas da sociedade. Tais argumentos confirmam a perspectiva apresentada por Machado Filho e Zylbersztajn (2004) de que o ambiente institucional é o principal motivador para induzir o comportamento da firma em relação às questões éticas e sociais.

Isso resulta na consideração de componentes diversos que têm efeito nas decisões do negócio, implicando na redefinição das atividades, redesenho de processos e reavaliação dos resultados pelos gerentes de diferentes áreas organizacionais (ALIGLERI et al, 2009; GRAYSON; HODGES, 2002). Assim, não são apenas os indicadores econômicos e financeiros que determinam o desempenho de um negócio, mas também se a empresa apresenta-se preocupada com a satisfação da sociedade no atendimento aos requisitos sociais e ambientais.

Nessa perspectiva, Elkington (2001) ressalta que o desafio central para a primeira metade do século atual será fazer com que as empresas operem de forma consistente para o apoio ao desenvolvimento sustentável e destaca, na Figura 2 que segue, algumas mudanças necessária no modelo de gestão para responder a esse novo contexto.

\begin{tabular}{|c|c|c|}
\hline \multicolumn{3}{|c|}{$\begin{array}{l}\text { Controle das Empresas } \\
\text { Os comitês se concentrarão cada vez mais na sustentabilidade e na linha } \\
\text { dos três pilares. }\end{array}$} \\
\hline & Antigo Paradigma & D Novo Paradigma \\
\hline 01 & Pilar financeiro & Dinha dos três pilares \\
\hline 02 & Capital físico e financeiro & D Econômico, humano, social, natural \\
\hline 03 & Ativos próprios, tangiveis & D Ativos emprestados, intangíveis \\
\hline 04 & Downsizing & $\boldsymbol{D}$ Inovação \\
\hline 05 & Governança exclusiva & D Governança inclusiva \\
\hline 06 & Acionistas & D Stakeholders \\
\hline
\end{tabular}

Figura 2 - Mudanças no paradigma de gestão FONTE: ELKINGTON, 2001, p. 335. 
O que se verifica atualmente é que não existe mais uma linha entre problemas que estão fora e dentro das empresas, sendo que as empresas devem compartilhar e contribuir com soluções. Caso contrário, as empresas poderão correr o risco de serem questionadas, processadas e cobradas pelos seus atos (BORGER, 2001).

A Sustainability (2005), uma renomada consultoria na área de sustentabilidade, colabora com a discussão ao destacar que estão ocorrendo sinais do potencial enrijecimento da responsabilidade civil envolvendo novas áreas de comprometimento por parte das empresas que não eram detectadas há duas décadas, como as mudanças climáticas, a geração de lixo, a obesidade, entre outros. Um exemplo são as novas leis implementadas em diversos países determinando a responsabilidade das empresas pelo recolhimento e descarte das embalagens e dos produtos pós-consumo. Kreitlon e Quintella (2001) corroboram e chegam a afirmar a existência de uma forte demanda por um "novo contrato social global" (KREITLON; QUINTELLA, 2001).

Portanto, as discussões sobre a conduta responsável das organizações têm evoluído continuamente, despertando a atenção da academia, que tem respondido com pesquisas crescentes para entender e qualificar as novas áreas de atuação organizacional.

\subsubsection{O Entendimento da Responsabilidade Socioambiental das Empresas}

Tomei (1984), Borger (2001) e Passador et al (2005) afirmam que o conceito de responsabilidade social das empresas está relacionado a diferentes ideias, por se defrontar com áreas limites da ética e da moral. Para uns, o conceito está associado ao cumprimento de obrigações legais e obrigações econômicas; para outros, significa um comportamento em sintonia com princípios éticos; ou ainda, pode ser entendido como uma contribuição voluntária a uma causa socioambiental específica. Trata-se, portanto, de um conceito complexo com significados diferentes em contextos diversos (GARRIGA; MELÉ, 2004).

Ashley e Macedo-Soares (2001) corroboram com essas ideias ao afirmar que a discussão conceitual sobre responsabilidade social pode ser vista como um contínuo que parte de pouca ou nenhuma mudança no papel da empresa e no modo de fazer negócios, dirigindo-se para 
configurações mais radicais, voltadas para as políticas e relações organizacionais, envolvendo um grande número de agentes externos e grupos de interesses.

É interessante observar que desde a década de setenta proliferaram definições de responsabilidade social empresarial, destacando-se os trabalhos de Davis (1967), Johnson (1971), Steiner (1971), Eells e Walton (1974), Sethi (1975), Preston e Post (1975) e Carroll (1979), sendo que esse último defendeu a atuação da empresa embasada num modelo de pirâmide envolvendo quatro dimensões na definição: responsabilidade econômica, legal, ética e filantrópica. A pirâmide da responsabilidade social desenvolvida por Carroll e apresentada na Figura 3 integrou, na época de seu desenvolvimento, a maioria dos argumentos do debate em uma única proposta teórica.

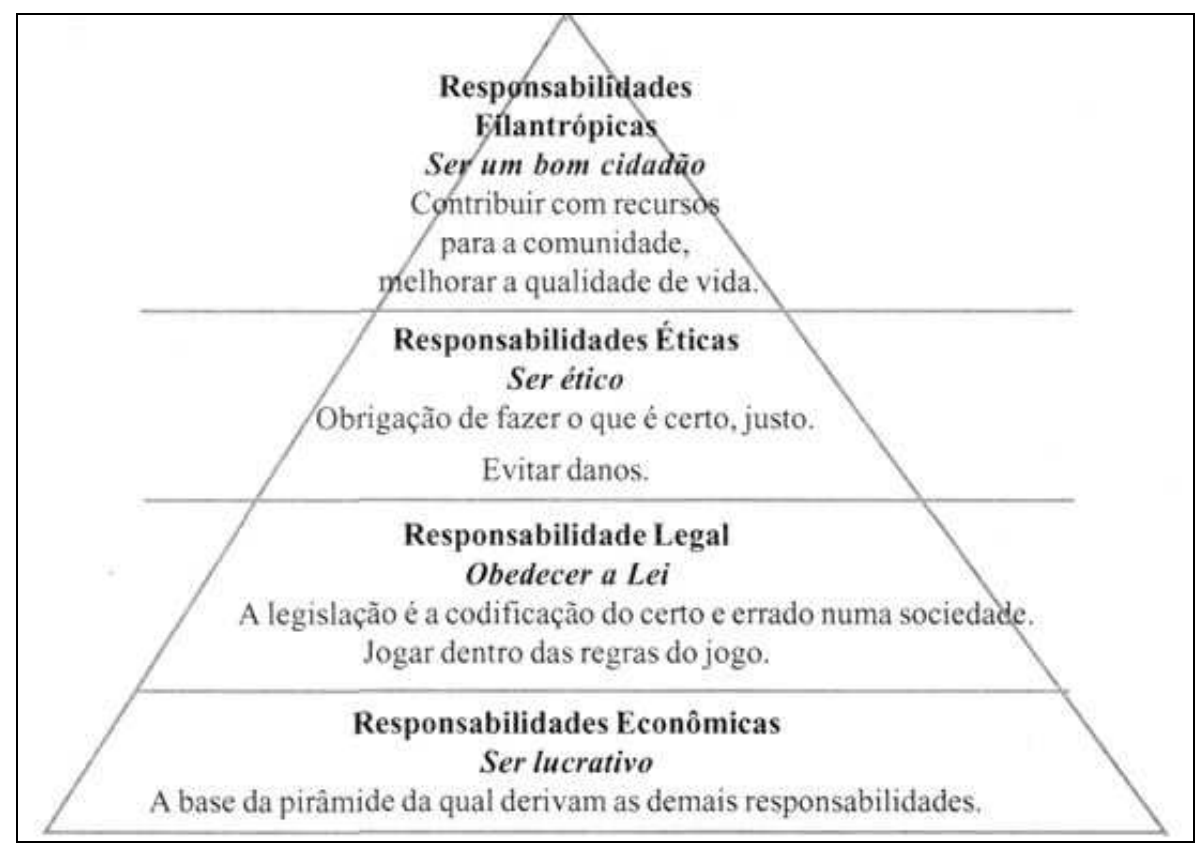

Figura 3 - Pirâmide da responsabilidade social corporativa FONTE: CARROLL, 1991, p. 42.

Em 2003, Schwartz e Carroll aperfeiçoaram a proposição apresentando novas perspectivas para entender o comportamento responsável das empresas. Na nova proposta, o esquema que sugeria uma hierarquia foi substituído por círculos para facilitar a representação visual, indicando três dimensões centrais da responsabilidade social: econômica, legal, e ética. A estrutura, conforme visualizado na Figura 4, se amplia em sete categorias intituladas: exclusivamente econômica, exclusivamente legal, exclusivamente ética, econômico-ética, econômico-legal, legal-ética e econômico-legal-ética, que resultam da sobreposição das três 
dimensões principais. Os autores afirmam ainda que nenhuma das três dimensões centrais deve ser considerada como mais importante ou significante comparada com as outras.

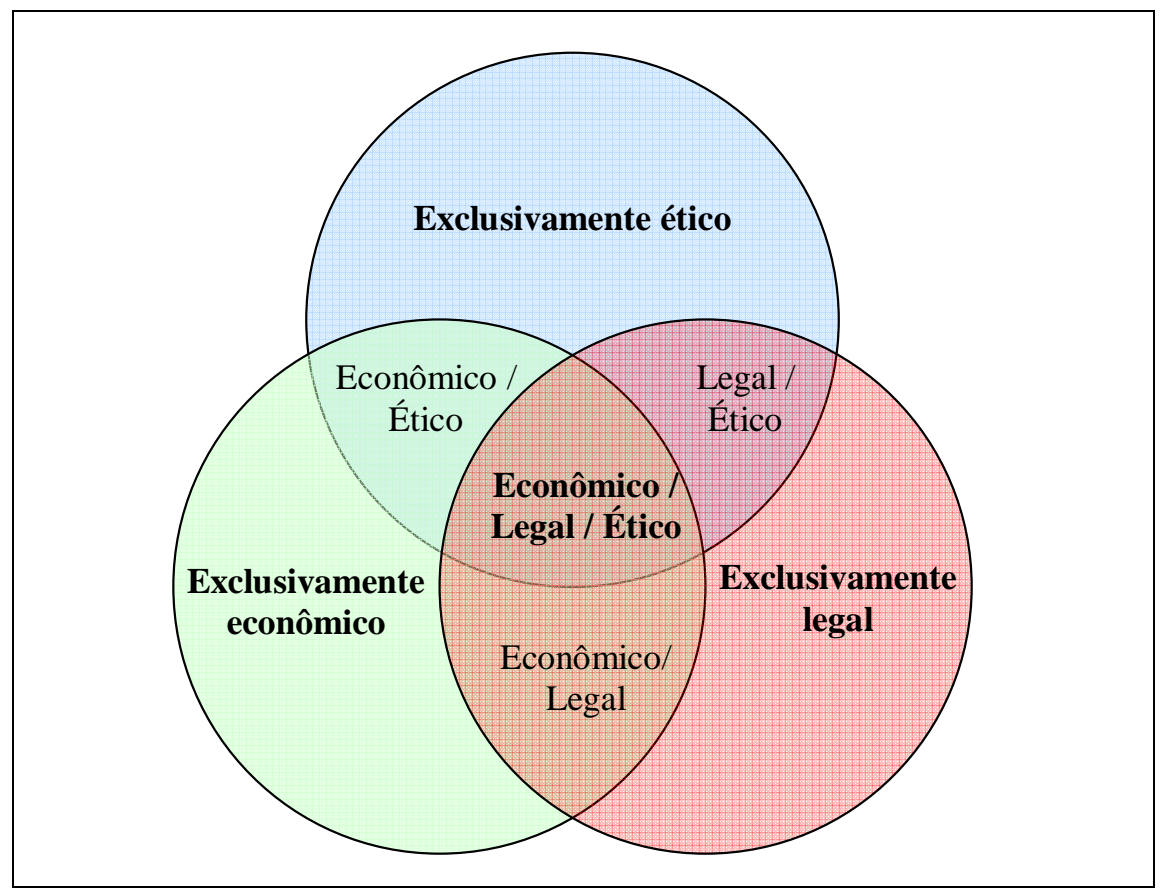

Figura 4 - Modelo das três dimensões da responsabilidade social FONTE: SCHWARZ; CARROLL, 2003, p. 509.

Ao longo do tempo, a complexidade do tema tornou-se maior uma vez que conceitos complementares aos de responsabilidade social também começaram a ser discutidos e delineados como cidadania empresarial, responsividade social, retitude social, gestão dos stakeholders, entre outros. Leal (2005) busca compreender esses conceitos e apresenta um quadro resumo, exposto na Figura 5, com alguns entendimentos. 


\begin{tabular}{|c|c|c|}
\hline \multicolumn{3}{|c|}{ Tabela 1 -Responsabilidade Social das Empresas e conceitos relacionados } \\
\hline Conceito & Definição & Autores \\
\hline $\begin{array}{l}\text { Corporate Social } \\
\text { Performance } \\
\text { (CSP) }\end{array}$ & $\begin{array}{l}\text { Conjunto de princípios de responsabilidade social, processos } \\
\text { socialmente responsáveis, politicas, programas e resultados } \\
\text { observáveis que evidenciem as relações da empresa com a } \\
\text { sociedade. O Modelo de CSP inclui principios, processos e } \\
\text { resultados socialmente responsáveis. }\end{array}$ & $\begin{array}{l}\text { Wartick e } \\
\text { Cochran } \\
(1985) \text {, citados } \\
\text { por Wood } \\
(1991) \text {. }\end{array}$ \\
\hline $\begin{array}{l}\text { Ética nos } \\
\text { negócios }\end{array}$ & $\begin{array}{l}\text { Refere-se como a empresa integra os valores essenciais (como } \\
\text { honestidade, confiança, respeito e justiça) nas suas politicas, } \\
\text { práticas e no processo de tomada de decisão em todos os niveis } \\
\text { da organização. Adicionalmente, envolve o cumprimento das } \\
\text { normas e padrões legais e a aderência às regras internas e } \\
\text { regulamentos. }\end{array}$ & Borger (2001) \\
\hline $\begin{array}{l}\text { Social } \\
\text { Responsiveness }\end{array}$ & $\begin{array}{l}\text { Capacidade de responder às pressões sociais; é a capacidade das } \\
\text { empresas para responderem de modo responsável aos desafios. } \\
\text { A empresa usa os seus recursos para antecipar as questões } \\
\text { sociais e desenvolver politicas, programas e outros meios de } \\
\text { lidar com eles. A gestão das questões sociais está integrada no } \\
\text { plano estratégico. }\end{array}$ & $\begin{array}{l}\text { Frederick } \\
(1978) \\
\text { Borger (2001) }\end{array}$ \\
\hline $\begin{array}{l}\text { Cidadania } \\
\text { Empresarial }\end{array}$ & $\begin{array}{l}\text { A cidadania empresarial inclui preocupações básicas como } \\
\text { desenvolver a competência empresarial, assegurar o futuro, } \\
\text { evitar riscos e proteger a reputação e inclui fazer as coisas certas, } \\
\text { reflectir sobre as crenças das pessoas e ser um lugar onde as } \\
\text { pessoas se sintam bem. }\end{array}$ & Borger (2001) \\
\hline $\begin{array}{l}\text { Stakeholder } \\
\text { Theory }\end{array}$ & $\begin{array}{l}\text { A stakeholder theory incorpora a noção de que as empresas têm } \\
\text { obrigações para com os grupos existentes na sociedade para } \\
\text { além dos accionistas e trabalhadores. Este modelo personaliza as } \\
\text { responsabilidades sociais, delineando os grupos especificos que } \\
\text { devem ser considerados na orientação da responsabilidade e } \\
\text { actuação social. }\end{array}$ & Freeman (1984) \\
\hline
\end{tabular}

Figura 5 - Conceitos relacionados à responsabilidade social das empresas FONTE: LEAL, 2005, p. 5.

Waddock (2004) argumenta que a ampla gama de abordagens desenvolveu-se, em parte, devido às diferentes disciplinas e área de conhecimento que buscam compreender o novo papel das empresas apresentando conceitos correlatos sem a integração entre os mesmos, o que dificulta a integração teórica.

Entretanto, pode-se afirmar que as principais características para a expressão responsabilidade social empresarial já se tornaram delineadas. Uma dessas premissas é que a conduta socialmente responsável implica em ir além de prescrições legais, incorporando o respeito pelas pessoas, pelas comunidades e pelo meio ambiente (MACHADO FILHO; ZYLBERSZTAJN, 2004; FURTADO, 2004).

Portanto, a discussão sobre a responsabilidade social das empresas perdeu a relação direta e única com projetos e ações filantrópicas e assistenciais restritos a sentimentos de boa vontade, de favor e ajuda aos mais necessitados e passou a compreender o comportamento e as 
transações vinculados a operação intrínseca da empresa (PRESTON; POST, 1975; DRUCKER, 1996; BORGER, 2004; GRAYSON; HODGES, 2002).

O que se verifica é que não adianta uma empresa desenvolver uma série de projetos sociais para a comunidade, sejam eles ligados a esporte, educação, cultura ou saúde, se, na realização de suas atividades, polui mananciais, submete funcionários a situações inseguras de trabalho, mantém contrato com fornecedores que utilizam mão-de-obra infantil, não paga os impostos devidos, envolve-se em cartéis ou paga salários menores às mulheres do que aos homens que ocupam cargos idênticos (SOUZA; MARCON, 2002).

O comportamento socialmente responsável deve estar presente em todas as decisões e rotinas gerenciais do negócio, perpassando diversas operações e níveis organizacionais. Isto é, envolve a contratação e demissão de pessoal, as políticas de compra, o consumo de recursos não renováveis, a política de marketing e comunicação ao consumidor, a segurança e condições de trabalho, a política de produção, a relação com a concorrência, entre outros (GRAYSON; HODGES, 2002; NASCIMENTO et al, 2008). Savitz (2007) chega a afirmar que, a exemplo da qualidade, a responsabilidade social deve ser impregnada, em vez de agregada, sendo difícil imaginar um gestor de uma unidade de negócio que, de alguma maneira, não se envolva nas iniciativas.

O Instituto Ethos (2010) defende essa perspectiva e conceitua a responsabilidade social envolvendo o componente da gestão, caracterizando-a como:

forma de gestão que se define pela relação ética e transparente da empresa com todos os públicos com os quais ela se relaciona e pelo estabelecimento de metas empresariais compatíveis com o desenvolvimento sustentável da sociedade, preservando recursos ambientais e culturais para as gerações futuras, respeitando a diversidade e promovendo a redução das desigualdades sociais.

Todavia, Wood Jr e Zuffo (1997) já destacaram que as fronteiras organizacionais estão se tornando cada vez mais permeáveis e difíceis de se identificar, levando ao que foi denominado pelos autores de "desfronteirização organizacional". Portanto, qualquer ponto fraco da cadeia de negócios prejudica a imagem responsável da empresa e do produto, desde o processo utilizado na extração de matéria-prima até as práticas de venda utilizadas pelos varejistas. Elkington (2001, p. 346) afirma que: "É inevitável, por exemplo, que empresas de sucesso terão cada vez mais responsabilidade pelo desempenho dos fornecedores." 
Desta forma, a designação de empresa e de produto socialmente responsável passa a ser incumbência não apenas de uma organização isolada, mas de toda a cadeia produtiva da qual ela faz parte. Não há como nominar uma empresa como socialmente responsável se o seu fornecedor atua de forma ambientalmente agressiva ou utiliza padrões de conduta antiéticos, bem como se o seu distribuidor pratica discriminação racial ou não apresenta condições mínimas de segurança no trabalho (ALIGLERI, 2002).

Isso faz com que a consistência de uma cadeia em questões ligadas ao social seja igual à resistência de seu elo mais fraco. Savitz (2007, p. 203) reforça essa afirmação ao publicar um posicionamento de Kert Davies, diretor de pesquisas do Greenpeace que diz: "Atacamos o elo mais fraco da cadeia de valor da empresa."

A responsabilidade social deve ter, portanto, uma abordagem baseada no entendimento de que as atividades logísticas são altamente interdependentes e operam segundo a teoria de sistemas, na qual a otimização das partes não significa necessariamente a otimização do todo. $\mathrm{O}$ produto só será legitimado como socialmente responsável pelo consumidor final, devendo, nesse caso, todo o ciclo produtivo ser construído de forma sustentável para que atinja tal objetivo.

Assim, a discussão abriu oportunidade para a reflexão da organização em si mesma, sua missão e suas relações com o mercado, provocando mudanças em atividades e políticas das áreas e subáreas da administração (ASHLEY, 2002; NASCIMENTO et al, 2008; ALIGLERI et al, 2009).

Mais recentemente, a partir da primeira década do século XXI, a discussão teórica vem avançando na perspectiva de que a responsabilidade social é um comportamento empresarial que contribui para o desenvolvimento sustentável da sociedade por proporcionar uma melhor qualidade de vida e gerar um fluxo de benefícios para empregados, clientes, parceiros de negócios e comunidades em que opera. Dessa forma, a conduta responsável da empresa colabora para a superação das crises sociais e ambientais estando, portanto, comprometida com o amanhã e com os pactos geracionais (BARBIERI; CAJAZEIRA, 2009; SAVITZ, 2007). 
Tais argumentos aproximam os conceitos de responsabilidade social e desenvolvimento sustentável que, segundo Barbieri e Cajazeira (2009) tiveram origens históricas distintas. O primeiro foi associado à questão da pobreza, e o segundo foi fomentado a partir dos movimentos ambientalistas.

Também se pode dizer que posturas socialmente corretas, ambientalmente sustentáveis e economicamente viáveis, isto é, o tríplice resultado também denominado de triple botton line (ELKINGTON, 2001; SAVITZ, 2007), colaboram com a sustentabilidade da empresa, definida por Scharf (2004) como a condição de prosseguir com as atividades por muito tempo. Uma empresa responsável torna-se sustentável no mercado, pois as práticas empreendidas podem gerar inúmeros benefícios ao negócio, tais como a atenção positiva da opinião pública, a promoção da imagem e da reputação corporativa, a motivação e elevação do moral do público interno, a vantagem competitiva, a fidelização de clientes, a retenção de funcionários e a melhoria do clima organizacional (MENDONÇA; GONÇALVES, 2002; ROCHLIN, 2005; MACHADO FILHO, 2006).

Savitz (2007, p. 41) destaca ainda a “[...] redução de custos, melhoria da produtividade, eliminação de desperdícios desnecessários e garantia de acesso a fontes de capital a custos mais baixos." Ademais, na medida em que a empresa cumpre algumas exigências implícitas e adota um comportamento pró-ativo, tais como respeito ao meio ambiente, por exemplo, os órgãos governamentais responsáveis poderão criar mecanismos menos rígidos de punição e de intervenção, que deixam de se constituir em custos não explícitos. De acordo com Campanhol e Breda (2005, p.5): “[...] em suma, a responsabilidade social é uma ação estratégica da empresa, que visa o retorno econômico, social, institucional, tributário fiscal."

Dessa forma, pode-se dizer que a responsabilidade social é um meio pelo qual as empresas buscam o desenvolvimento sustentável da sociedade e do próprio negócio. A ISO 26000, uma importante iniciativa internacional no campo das normas de conduta em responsabilidade social, lançada em 2010, também a compreende nessa perspectiva e apresenta a seguinte definição:

a responsabilidade de uma organização pelos impactos de suas decisões e atividades (produtos, serviços e processos) na sociedade e no ambiente, por meio de um comportamento transparente e ético que: contribui para o desenvolvimento sustentável, para a saúde e o bem-estar da sociedade; leva em consideração as expectativas dos stakeholders; está em conformidade com a legislação 
aplicável e é consistente com as normas internacionais do comportamento; e está integrado na organização e é praticado em seus relacionamentos. (p. 8).

Isso faz com que movimentos com características próprias e campos de estudos específicos convirjam para o conceito de empresa sustentável. Scharf (2004, p. 19) também acredita nessa perspectiva e colabora elencando alguns comportamentos que definem uma empresa sustentável na atualidade, sendo aquela que:

a) Mantém uma perspectiva de rentabilidade econômica no médio e longo prazo.

b) Opera dentro da lei, sem passivos que possam gerar prejuízos inesperados.

c) Minimiza sua dependência de recursos sujeitos a escassez ou esgotáveis.

d) Diminui seus impactos sobre os recursos naturais e a paisagem.

e) Desenvolve produtos ou serviços que contribuem para o que é percebido pela sociedade como um benefício social ou ambiental.

f) Estabelece uma relação de respeito e evita o conflito com seus funcionários, fornecedores, clientes, acionistas e públicos de relacionamento.

g) Preocupa-se com o impacto de seus bens e serviços ao longo de todo o ciclo de vida.

h) Reduz os resíduos e recicla os materiais que descarta.

i) Tem transparência na gestão, promovendo assim a confiança.

j) Evita o uso de formas de propaganda maliciosa que induzem o público a confundir a verdadeira atuação da empresa com ações beneficentes que não influenciam sua atuação.

k) Relaciona-se com demandas de ordem global (o aquecimento do planeta ou o surgimento de consumidores engajados em outros continentes) e local (a comunidade que sua atuação afeta), simultaneamente.

Assim, a criação de valor sustentado para a sociedade e para os proprietários do negócio exige desempenho multidimensional e abordagens de gestão baseadas na complexidade e na visão sistêmica, incorporando novas condutas e expectativas do contexto no qual a empresa está inserida.

\subsubsection{Gestão dos Stakeholders}

Os debates sobre o papel da empresa e a sua conduta potencializaram discussões teóricas sobre o ambiente das empresas e os seus diferentes constituintes. Tais debates fomentaram uma nova relação das empresas com os públicos de relacionamentos, denominados de 
stakeholders, implicando que os dirigentes das organizações contemporâneas dêem respostas adequadas as suas demandas.

O termo stakeholder expandiu-se com as obras de Freeman do início da década de 1980 e tem sido usado em diversas áreas de administração como planejamento e estratégia corporativa, teoria das organizações, teoria de sistemas e responsabilidade social das empresas. No Brasil a expressão tem sido traduzida como "parte interessada", "grupo de interesse" ou "público de interesse".

Stakeholder significa “[...] qualquer grupo ou indivíduo que pode afetar, ou é afetado, pelo alcance dos propósitos de uma firma" (FREEMAN, 1984); ou ainda pode ser entendido como “indivíduo ou grupo que tem um ou mais de vários tipos de interesses em um negócio." (CARROLL; BUCHWOLTZ, 2000). Já Silva (2006, p. 49) define-o como “[...] pessoas, grupos de pessoas e outras entidades, com interesses legítimos nas ações e operações das organizações, que podem afetar ou ser afetados por elas [...]”, conceito adotado nesta tese.

Tal conceito, conforme destacado por Borger (2004), evidencia que na atividade empresarial deve ser considerado o caráter político e transacional entre a organização e seus públicos de interesse. Além disso, salienta que para entender a dinâmica dos negócios é preciso compreender a rede de relações cooperativas e competitivas que envolvem as empresas.

Uma forma de clarificar a complexidade decorrente da diversidade dos stakeholders é classificá-los segundo algum critério, pondo nome e face nos grupos mais importantes para os negócios. Nessa perspectiva, Donaldson e Preston (2002) afirmam que os agrupamentos dos stakeholders podem ser apresentados e usados de modos distintos, envolvendo diferentes métodos, tipos de evidência e critérios de avaliação.

Stoner e Freeman (1995) classificam os stakeholders dentro do ambiente de ação direta e indireta. No ambiente de ação direta, dividem-se em duas categorias: (1) interna - composta de acionistas, investidores, proprietários, conselho de administração e funcionários; (2) externa - inclui grupos como sindicato, competidores, fornecedores, grupos governamentais e clientes, por exemplo. No ambiente de ação indireta estão os elementos do ambiente externo que afetam o clima em que a organização atua, como a economia, a política e a tecnologia. 
Na visão de Wheeler e Sillanpää (1997, apud CARROLL; BUCHWOLTZ, 2000) os stakeholders podem ser divididos em duas categorias (primários e secundários), sendo que cada uma delas pode ser subdividida em dois tipos (sociais e não sociais). Assim, formam-se quatro grandes grupos, sendo eles:

a) stakeholders sociais primários, que possuem interesse direto no desempenho da organização como empregados, acionistas, fornecedores, investidores, consumidores, entre outros;

b) stakeholders sociais secundários, que embora não estejam diretamente vinculados ao negócio, podem influenciar e afetar a empresa como governo, órgãos reguladores, sindicato, mídia, entre oturos;

c) stakeholders não-sociais primários, sendo aqueles que possuem como característica a impossibilidade de contato com a organização como o meio ambiente, futuras gerações, espécies não humanas e;

d) stakeholders não sociais secundários, formado por um amplo e diverso conjunto de agentes como grupos de pressão ambiental e organizações protetoras dos animais, entre outros.

Hitt et al (2002) propõe uma outra forma de classificação relacionada com a função dos grupos de interesse nas organizações, denominados:

a) stakeholders de capital entendidos por acionistas e principais provedores de capital como bancos, agentes financeiros e fundos de investimento;

b) stakeholders de produto e mercado envolvendo clientes, fornecedores, comunidades locais e sindicatos e;

c) stakeholders organizacionais abrangendo empregados e executivos.

Outras tipologias como as propostas por Savage et al (1991), Mitchell et al (1997), Frooman (1999) e Walker e Marr (2001) buscam classificá-los de forma instrumental em relação a influências, riscos e oportunidades para o negócio.

Todas as classificações apresentam a organização e a sociedade como sistemas interpenetrantes e interdependentes, reafirmando a proposição de Srour (2000, p.279): “Da mesma forma que os agentes sociais não existem por si mesmos, mas apenas e tão somente porque fazem parte da sociedade que os abriga e lhes faculta a própria existência, as empresas são obviamente gregárias - dependem da teia de conexões presentes no mercado.” 
Essas diferentes abordagens reforçam, direta ou indiretamente, a importância do processo de construção de relação e gestão das partes interessadas. Perspectiva também defendida nos estudos que discutem a responsabilidade social das empresas. Isso pode explicar por que muitos acadêmicos relacionam o comportamento responsável à teoria dos stakeholders (ZADEK, 1998; ASHLEY，2002; BORGER; KRUGLIANSKAS，2002; KREITLON; QUINTELLA, 2001; GRAYSON; HODGES, 2002). Ashley (2002, p.17), ao destacar a conduta socioambiental das empresas, afirma que "[...] as relações de troca passam a ser o foco de reflexão, considerando-se que as trocas não se dão exclusivamente em aspectos econômicos, mas incluem relações de confiança, ideias e normas éticas."

Savitz (2007, p. 205) corrobora com esse entendimento e destaca que "[...] no mundo interdependente de hoje, a maneira de controlar uma situação difícil, da qual participem stakeholders, é, em geral, ceder-lhes parte do controle, trabalhando em cooperação e abrindo mão do domínio absoluto." O autor defende que envolver os stakeholders nas decisões e atividades do negócio que possam afetá-los é ferramenta eficaz para converter a hostilidade em energia positiva, representando um fator crítico para a continuidade do negócio.

Portanto, o estilo de administração preconiza a colaboração e parceria, em substituição ao confronto. O que, na opinião de Elkington (2001, p. 342) implica em "[...] mudar de subversão mútua para evolução de novas formas de simbiose."

Todavia, Borger $(2004$, p. 24) observa que essa forma de gestão não é tão fácil de ser executada pelos gestores:

\footnotetext{
Cada parte interessada espera que as decisões estratégicas venham ao encontro de seus objetivos, mas estes freqüentemente diferem de um grupo para outro, pondo os administradores em situações de escolha entre um e outro. Em linhas gerais, os acionistas querem maximizar seus retornos, preservar e aumentar sua riqueza; os consumidores querem qualidade e confiabilidade dos serviços e produtos sem aumento de preços; os fornecedores querem aumentar o preço e reduzir os custos; a comunidade quer que as empresas sejam empregadores de longo prazo, paguem mais impostos e não demandem serviços de infra-estrutura; e finalmente os organizacionais esperam que a firma forneça um ambiente de trabalho dinâmico, estimulante e compensador.
}

Dessa forma, pode-se dizer que o engajamento socioambiental das empresas é visto pelos pesquisadores e gestores como um processo de construção da relação com as partes 
interessadas, administrando, não as relações, mas suas expectativas e as decisões de como as sustentarão (BORGER, 2004).

\subsubsection{Gestão Responsável e Sustentável}

Para implementar uma gestão socialmente responsável em consonância com os princípios do desenvolvimento sustentável, a empresa pode contar com um variado número de conceitos, modelos, princípios e instrumentos de gestão que contribuem para a definição de empresa sustentável.

Embora as premissas do entendimento sobre responsabilidade social venham se definindo, os instrumentos e indicadores para apoiar tal envolvimento ainda não se encontram consolidados. Muitos pesquisadores e organizações têm criado seus próprios ferramentais para planejar, organizar e avaliar os temas referentes à responsabilidade social em nível estratégico e operacional. Barbieri e Cajazeira (2009, p. 211) afirmam que: "A caixa de ferramentas para dar suporte à política de responsabilidade social é variada e não cessa de crescer, o que revela a importância desse tema para as empresas, que por sua vez reflete demandas da sociedade nesse sentido."

Essas iniciativas, de origens e propósito distintos, podem ser compreendidas, na concepção de Barbieri e Cajazeira (2009), em dois grandes blocos. O primeiro, circunscrito aos princípios diretivos presentes em documentos que representam consensos internacionais. O segundo bloco caracterizado por instrumentos administrativos e operacionais que definem ações e procedimentos específicos sobre responsabilidade social.

Nesta tese, acrescenta-se a esses dois blocos um terceiro grupo formado por modelos de gestão estratégica da responsabilidade social, propostos por diversos autores, que pretendem auxiliar os gestores na tomada de decisão e viabilizar o desempenho competitivo da empresa em consonância com a geração de valor socioambiental.

\subsubsection{Princípios Diretivos}

Declarações, acordos e outros documentos intergovernamentais multilaterais, bem como princípios e códigos contendo diretrizes e temas emergentes podem ser fontes orientadoras 
para a definição de valores, missão, visão, políticas e alocação de recursos na esfera da gestão empresarial. Esses documentos, desenvolvidos por instituições com legitimidade global, propõem o comportamento mínimo aceitável para a operação das organizações. Nessa perspectiva, Louette (2007, p. 37) reforça que:

[...] temas como direitos humanos, direitos do trabalho, meio ambiente e desenvolvimento sustentável ganham vulto na discussão entre os países membros das Nações Unidas, resultando em diretrizes que, de certa forma, orientam a formulação conceitual da RSE no âmbito principalmente global.

Destaca-se abaixo uma pequena descrição de alguns desses documentos desenvolvidos pelas Nações Unidas e seus organismos, relatados nas publicações "Compêndio para a Sustentabilidade: ferramentas de gestão para a sustentabilidade", organizado por Louette (2007) e "Critérios Essenciais de Responsabilidade Social Empresarial e seus Mecanismos de Indução", publicado pelo Instituto Ethos (2007).

- Declaração Universal dos Direitos Humanos (1948): proclamada pela Assembleia Geral das Nações Unidas é um documento com 30 artigos que enuncia os direitos e liberdades fundamentais de todos os humanos, destacando-se a liberdade de locomoção, de pensamento, de igual salário por trabalho igual, de repouso e lazer, de educação, entre outros.

- Diretrizes da OCDE para Multinacionais (1976): são recomendações dirigidas pelos governos dos países membros da OCDE (Organização para a Cooperação e o Desenvolvimento Econômico) às empresas multinacionais para o desenvolvimento de suas atividades em todo o mundo. As diretrizes descrevem padrões voluntários, recomendações para uma conduta empresarial responsável em uma ampla gama de questões sociais e ambientais, tais como direitos humanos, divulgação de informações, trabalho e meio ambiente. A última revisão do documento foi realizada em 2000, data em que o Brasil adotou as diretrizes.

- Agenda 21 (1992): aprovada durante a Conferência das Nações Unidas sobre o Meio Ambiente e Desenvolvimento Humano, podendo ser definida como um plano de ação para ser adotado em escala global, nacional e local por organizações, pelos governos e pela sociedade civil, em todas as áreas em que a ação humana impacta o meio. Reflete um compromisso público com o desenvolvimento sustentável, enumerando objetivos a serem atingidos. $\mathrm{O}$ documento apresenta 40 capítulos e está dividido em quatro seções: dimensões econômicas e 
sociais; conservação e gerenciamento de recursos para o desenvolvimento; fortalecimento do papel dos grupos; e meios de implementação.

- Carta da Terra (1997): nasceu como resposta às ameaças que se instalam sobre o planeta. Busca, portanto, pensar articuladamente os muitos problemas ecológico-sociais, tendo como referência central a Terra. Pretende-se equiparar-se à Declaração Universal dos Direitos Humanos, no tocante a sustentabilidade, justiça econômica, ética e paz. A partir de 2000, passou a ser divulgada pela Iniciativa Internacional da Carta da Terra, visando sua transformação em um código ético universal. Sua aprovação, pelas Nações Unidas, ocorreu em 2002.

- Protocolo de Quioto (1997): constitui-se no protocolo de um tratado internacional com compromissos para a redução da emissão dos gases que provocam o efeito estufa, considerados, de acordo com a maioria das investigações científicas, como causa do aquecimento global. O documento propõe um calendário no qual os países desenvolvidos têm a obrigação de reduzir a quantidade de gases poluentes em, pelo menos, 5,2\% até 2012, em relação aos níveis de 1990. Os países signatários já colocam em prática planos para reduzir a emissão desses gases desde 2008.

- Princípios e Direitos Fundamentais no Trabalho (1988): também conhecida como a Declaração da OIT (Organização Internacional do Trabalho) que reafirma o compromisso dos estados membros, e da comunidade internacional em geral, com o respeito e a promoção da liberdade de associação e de organização sindical, incluindo o efetivo do direito de negociação coletiva; a eliminação de todas as formas de trabalho forçado ou obrigatório; a abolição efetiva do trabalho infantil, e a eliminação da discriminação em matéria de emprego e ocupação.

- Pacto Global (1999): uma iniciativa das Organizações das Nações Unidas voltada para empresas, buscando conciliar práticas de gestão com novas condutas socioambientais. $\mathrm{O}$ documento fundamenta-se em 10 princípios ligados a direitos humanos, relações de trabalho, meio ambiente e combate à corrupção. O Pacto Global foi concebido como um fórum aberto à participação de todos os tipos de empresas por meio de uma declaração de apoio.

- Metas do Milênio (2000): documento que consolidou várias metas estabelecidas nas conferências mundiais ocorridas ao longo dos anos 90, estabelecendo um conjunto de objetivos para o desenvolvimento - os chamados Objetivos de Desenvolvimento do Milênio (ODM) - que devem ser adotados pelos estados membros das Nações Unidas e alcançados até 2015. Oito objetivos foram definidos: 1- Erradicar a extrema pobreza e a fome; 2- Atingir o ensino básico universal; 3- Promover a igualdade de gênero e a autonomia das mulheres; 4- 
Reduzir a mortalidade infantil; 5- Melhorar a saúde materna; 6- Combater o HIV /AIDS, a malária e outras doenças; 7- Garantir a sustentabilidade ambiental; 8- Estabelecer uma parceria mundial para o desenvolvimento. A partir desses oito objetivos internacionais, 18 metas e 48 indicadores foram definidos para possibilitar uma avaliação uniforme nos níveis global, nacional e regional, possibilitando uma avaliação do compromisso das nações com a geração atual e futuras.

Podem ser destacados ainda a Convenção de Viena para a Proteção da Camada de Ozônio (1985), o Protocolo de Cartagena sobre Biosegurança (2000), a Convenção de Estocolmo sobre Poluentes Orgânicos Persistentes (2001), a Convenção da ONU contra a Corrupção (2001), entre outros.

\subsubsection{Instrumentos de Gestão}

Diversos instrumentos normativos de gestão sustentável foram desenvolvidos nos últimos anos, sendo que muitos deles incluem alguns dos princípios diretivos. Barbieri e Cajazeira (2009), conforme apresentado no Quadro 5, propõem classificar os instrumentos de gestão em três grupos, sendo eles:

a) aqueles que apresentam orientações para manter um sistema de gestão, na forma de normas, com programas e atividades;

b) aqueles que pretendem garantir a transparência e a comunicação com as partes interessadas e;

c) aqueles que possibilitam a integração e compatibilidade entre sistemas de gestão.

O primeiro grupo de instrumentos de gestão qualificados por Barbieri e Cajazeira (2009) como aqueles que buscam promover orientações processuais específicas para implementar e manter sistemas de gestão, programas e atividades é essencialmente formado por normas. $\mathrm{O}$ IBCG (2007) entende esse mesmo grupo de ferramentas como sendo baseado em processos, uma vez que descrevem atividades e procedimentos que a organização deveria seguir para melhorar seu desempenho. 
Quadro 5 - Instrumentos para a gestão sustentável

\begin{tabular}{|c|c|}
\hline Objetivos & Exemplos \\
\hline $\begin{array}{l}\text { Promover orientações processuais específicas } \\
\text { para implementar e manter sistemas de } \\
\text { gestão, programas e atividades. }\end{array}$ & $\begin{array}{ll}\text { - } & \text { Norma ISO } 9001 \\
\text { - } & \text { Norma ISO } 14001 \\
\text { - } & \text { Norma SA } 8000 \\
\text { - } & \text { Norma AA } 1000 \\
\text { - } & \text { Norma OHSAS } 18001 \\
\text { - } & \text { Norma NBR } 16001 \\
\text { - } & \text { Norma AFNOR SD } 21000\end{array}$ \\
\hline $\begin{array}{l}\text { Garantir a transparência da comunicação com } \\
\text { suas partes interessadas. }\end{array}$ & $\begin{array}{ll}\text { - } & \text { Balanço Social } \\
\text { - } & \text { Indicadores Ethos de Responsabilidade Social } \\
\text { - } & \text { GRI - Global Reporting Initiative } \\
\text { - } & \text { ISE - Indicadores de Sustentabilidade } \\
& \text { Empresarial (Bovespa) } \\
\text { - } & \text { Norma ISO } 14063\end{array}$ \\
\hline $\begin{array}{l}\text { Garantir a integração e compatibilidade entre } \\
\text { sistemas de gestão. }\end{array}$ & $\begin{array}{ll}\text { - } & \text { Projeto Sigma } \\
\text { - } & \text { Guia ISO } 72 \\
\text { - } & \text { Norma ISO/TC207/TC176/N } 180\end{array}$ \\
\hline
\end{tabular}

FONTE: BARBIERI; CAJAZEIRA, 2009, p. 172.

Apresenta-se abaixo um resumo das normas, destacando-se, além das descritas por Barbieri e Cajazeira (2009), a Norma ISO 26000 lançada pela International Organization for Standardization em novembro de 2010.

- Norma ISO 9001: lançada em 1994 pela International Organization for Standardization, faz parte de um conjunto de normas da série ISO 9000. Apresenta requisitos para um Sistema de Gestão da Qualidade que possa ser auditado e certificado. A versão atual da norma do ano de 2008 foi elaborada para apresentar maior compatibilidade com a família da ISO 14000.

- Norma ISO 14001: lançada em 1996 pela International Organization for Standardization, faz parte de um conjunto de normas da série ISO 14000. Fornece requisitos para auditar e certificar um Sistema de Gestão Ambiental visando estabelecer na empresa processos para controlar ou reduzir impactos ambientais de maior significância.

- Norma SA 8000: elaborada em 1997 e revisada em 2001 pela organização nãogovernamental norte-americana denominada Social Accountability International (SAI), é uma norma que estabelece padrões para as relações de trabalho, passível de auditoria e 
certificação. Reconhecida como um sistema de implementação, manutenção e verificação de condições dignas de trabalho e respeito dos direitos fundamentais dos trabalhadores.

- Norma AA 1000: lançada em 1999 pelo Institute of Social and Ethical Accountability (ISEA), uma organização não-governamental com sede em Londres. É uma norma composta por princípios e padrões de processo focados no engajamento com as partes interessadas. É um padrão passível de integração com outras normas, especificando o processo a ser seguido na construção do relatório de desempenho.

- Norma OHSAS 18001: lançada em 1999, cuja sigla significa Occupational Health and Safety Assessment Series, tendo contado com a participação de organismos certificadores e de entidades de normalização de diversos países. Norma passível de auditoria e certificação auxiliando as empresas a controlar os riscos de acidentes no local de trabalho através de sistemas de gestão da Segurança e da Saúde no Trabalho (SST).

- Norma AFNOR SD 21000: criada em 2003 pela Associação Francesa de Normalização (AFNOR) pode ser considerada a contribuição francesa para o debate internacional sobre as normas de desenvolvimento sustentável. Porém, as recomendações não são destinadas para certificação sendo apenas um guia de boas práticas.

- Norma NBR 16001: norma brasileira lançada em 2004 por um grupo-tarefa composto de representantes de diversos setores da sociedade sob coordenação da Associação Brasileira de Normas Técnicas (ABNT). É passível de certificação, podendo ser auditada, fornecendo requisitos mínimos para que a organização implante um sistema de gestão da responsabilidade social.

- Norma ISO 26000: lançada em 2010 pela International Organization for Standardization e desenvolvida com a participação e diversos países e organizações internacionais. É percebida como uma das mais importantes iniciativas internacionais no campo das normas de conduta em responsabilidade social. Diferentemente da ISO 9001 e da ISO 14001, esta não é uma norma para certificação, pelo menos nesta primeira versão. A norma estabelece um padrão internacional de diretrizes de responsabilidade social, elencando temas centrais para envolvimento das empresas.

Sobre esse conjunto de ferramentas, Carrieri et al (2009) salientam que na medida em que as instituições proponentes ganham destaque no âmbito global, a legitimação das certificações cresce. Já Elkington (2001) enfatiza que as normas fornecem plataformas na forma de orientações práticas, ajudando a estabelecer comportamentos a partir das quais as empresas 
poderão atingir objetivos mais relevantes. Entretanto, o autor argumenta que elas não asseguram que as companhias terão progresso e desempenho suficiente na direção correta.

O segundo conjunto de instrumentos normativos definidos por Barbieri e Cajazeira (2009) são aqueles que pretendem garantir transparência e comunicação com as partes interessadas. Tal grupo é classificado pelo IBGC (2007) como ferramentas baseadas no desempenho, isto é aquelas que se propõem a relatar o que a organização efetivamente faz, a partir de uma lista de indicadores em relação aos quais a empresa deve se comparar.

A literatura acadêmica tem destacado, com grande ênfase, que o progresso na direção de atitudes e comportamentos corretos precisam ser medidos. Complementarmente, ampliam-se estudos que fazem críticas aos sistemas tradicionais de mensuração de desempenho, propondo medidas não-financeiras quantificáveis de resultados sociais e ambientais, além do econômico (ELKINGTON, 2001; GRAYSON; HODGES, 2002; PACE et al, 2003; FURTADO, 2003; SAVITZ, 2007; HOURNEAUX, 2010).

Cresce, portanto, o papel e a importância de medidas de desempenho, através de um conjunto de regras estabelecidas, para focar pessoas e recursos na direção socioambiental. Entretanto, uma crítica para esse tipo de instrumento refere-se à definição de indicadores de avaliação sensíveis ao contexto de cada empresa, implicando, muitas vezes, em questionamentos sobre o escopo das medições (IBGC, 2007).

Abaixo é apresentado um resumo dos principais instrumentos baseados em desempenho elecandos por Barbieri e Cajazeira (2009):

- Balanço Social: É um demonstrativo numérico sobre as atividades sociais da empresa. No Brasil, o modelo mais utilizado foi criado em 1997 pelo Instituto Brasileiro de Análises Sociais e Econômicas (IBASE). O documento é estruturado na forma de tabela e reúne um conjunto de informações sobre os projetos, benefícios e ações sociais dirigidas aos empregados, investidores, analistas de mercado, acionistas e à comunidade.

- Indicadores Ethos de Responsabilidade Social: desenvolvido em 2000 e atualizado anualmente pelo Instituto Ethos de Empresas e Responsabilidade Social. É um questionário organizado em sete temas, utilizado pelas empresas para diagnóstico e avaliação de sua gestão 
no tocante à incorporação da responsabilidade social. Possui indicadores setoriais complementares.

- Global Reporting Initiative: foi criado em 2000 pela Global Reporting Initiative (GRI), sediada na Holanda, com a participação de diversas entidades. Propõe um padrão internacional de diretrizes e estrutura para comunicação, na forma de relatório, sobre a conduta socioambiental da empresa. O modelo, dividido em seis categorias, pode ser considerado um balanço constituído por um conjunto de indicadores econômicos, sociais e ambientais. Sua estrutura e conteúdo sofrem processo constante de revisão.

- Indicadores de Sustentabilidade Empresarial: criado em 2005 pela Bolsa de Valores de São Paulo em parceria com a Fundação Getulio Vargas, é uma ferramenta, na forma de questionário, que objetiva comparar o desempenho de empresas listadas na BM\&F BOVESPA, sob os aspectos da sustentabilidade. O documento é dividido em seis dimensões e contempla questões específicas de acordo com o setor de atividade da companhia. O questionário é atualizado anualmente.

O terceiro e último grupo de instrumentos foi definido por Barbieri e Cajazeira (2009) como aqueles que buscam garantir a integração e a compatibilidade entre diferentes sistemas de gestão, o que o IBGC (2007) denominou de ferramentas híbridas. Isto é, aquelas que combinam elementos das abordagens anteriormente citadas, numa estrutura que objetiva disponibilizar um conjunto de princípios, uma orientação prática sobre o que deve ser feito e a possibilidade de aferir desempenho.

Numa lista de exemplos, além das descritas por Barbieri e Cajazeira (2009), destaca-se ainda o The Natural Step citado por Louette (2007), IBGC (2007) e Instituto Ethos (2007).

- Project Sigma: lançado em 1999 com o apoio do Departamento de Indústria e Comércio do Reino Unido, é uma parceria entre a British Standards Institution (BSI), o Forum for the Future e AccountAbility. Trata-se de um conjunto de diretrizes e ferramentas para empresas que visam contribuir efetivamente para o desenvolvimento sustentável. É a síntese de vários modelos e instrumentos no campo da responsabilidade social empresarial, buscando integração entre as ferramentas e melhoria de desempenho. Ele pode ser usado sozinho ou em conjunto com outras iniciativas.

- Guia ISO 72: criado em 2001 pela International Organization for Standardization. É um guia para elaboradores de normas que inclui uma estrutura-modelo para produzir normas 
que envolvam diversos elementos de maneira consistente. Propõe que nas novas normas de sistema de gestão estejam presentes seis temas, permitindo uma maior integração entre diferentes propostas.

- The Natural Step: criado na Suécia em 1989, postula a necessidade de quatro condições sistêmicas essenciais para a manutenção da vida na Terra. Trata-se de um guia com condições fundamentais para uma sociedade sustentável, construídas a partir de um consenso de cientistas e com uma metodologia para o planejamento de negócios/tomada de decisões. A estrutura do Natural Step auxilia indivíduos e organizações a enfocar questões-chaves ambientais e sociais por meio de uma perspectiva sistêmica, reduzindo o uso de recursos naturais, desenvolvendo novas tecnologias e facilitando a comunicação da empresa.

Nesta seção foram destacadas algumas das ferramentas mais usualmente relatadas na literatura, dentre um grande número de proposições que não param de crescer. Percebe-se que os diferentes entendimentos de organização e empresa responsável levaram a uma enorme quantidade de iniciativas. Isso significa que a empresa tem à disposição instrumentos distintos para implementar sua política de responsabilidade social, sendo que a diversidade pode tornar-se um problema de escolha para o gestor.

Nessa perspectiva, Barbieri e Cajazeira (2009, p. 171) afirmam que: "Uma questão tão complexa quanto a Responsabilidade Social Empresarial, que envolve assuntos tão diversos e com inúmeras interações entre eles, só pode ser suficientemente inserida em uma organização por meio de várias ferramentas de gerenciamento." Entretanto, os autores e também um grande número de pesquisadores que defendem o mesmo ponto de vista não discriminam quais delas podem ser empreendidas conjuntamente para melhorar a eficácia organizacional. Talvez isso explique, conforme já relatado por Giovannini e Kruglianskas (2004), a disseminada insatisfação com o desempenho das organizações e a busca por modelos estratégicos de gestão que permitam entender melhor a dinâmica das empresas apontando caminhos de atuação.

\subsubsection{Modelos de Gestão da Responsabilidade Social: abordagens integradas às políticas estratégicas}

Diversos pesquisadores da área da administração vêm despendendo horas de trabalho para propor modelos de gestão que visam compreender e delimitar a atuação socioambiental da 
empresa. Freire et al (2009) num estudo que objetivou identificar os trabalhos mais citados no âmbito acadêmico, encontraram os modelos desenvolvidos por Carroll (1979), Wartick e Cochran (1985), Carroll (1991), Wood (1991) e Schwartz e Carroll (2003).

Entretanto, conforme disposto no Quadro 6, pode-se elencar, nos últimos trinta e cinco anos, mais de dezoito proposições teóricas citadas ou publicadas em revistas internacionais como Academy of Management Review, Business \& Society, California Management Review, Harvard Business Review, Journal Business Ethics, Business Ethics Quarterly Business Horizons. Bakker et al (2007); Freire et al (2009) e Welzel (2009) são exemplos de pesquisadores que realizaram estudos bibliográficos de caráter exploratório em periódicos internacionais para compilar modelos explicativos de responsabilidade social das empresas.

Quadro 6 - Modelos explicativos sobre a responsabilidade social das empresas

\begin{tabular}{|c|c|c|}
\hline Autor & Fonte da Publicação & Proposições \\
\hline $\begin{array}{l}\text { Davis e } \\
\text { Blomstrom } \\
\quad(\mathbf{1 9 7 5 )}\end{array}$ & $\begin{array}{l}\text { Business and society: } \\
\text { environment and } \\
\text { responsibility. New } \\
\text { York: McGraw-Hill, } 1975 .\end{array}$ & $\begin{array}{l}\text { Propõe o Modelo dos Três Círculos Concêntricos - o primeiro } \\
\text { círculo, interno, representa a dimensão econômica, constituída } \\
\text { por produto, trabalho e crescimento. O círculo intermediário } \\
\text { diz respeito ao exercício da função econômica considerando } \\
\text { valores sociais. E o círculo exterior refere-se às } \\
\text { responsabilidades amorfas que a empresa deveria considerar, } \\
\text { tais como questões relacionadas à pobreza, exclusão, entre } \\
\text { outras. }\end{array}$ \\
\hline $\begin{array}{c}\text { Ackerman } \\
\text { (1973) }\end{array}$ & $\begin{array}{l}\text { How companies respond to } \\
\text { social demands. Harvard } \\
\text { Business Review, } \\
\text { v.51, n. } 4.1973 .\end{array}$ & $\begin{array}{l}\text { Aponta três fases em que as empresas desenvolvem uma } \\
\text { reação às questões sociais. Na fase } 1 \text {, os executivos do topo } \\
\text { gerencial tomam conhecimento da existência de um problema } \\
\text { social. Na fase } 2 \text {, a empresa contrata especialistas para sugerir } \\
\text { maneiras de lidar com o problema e formular planos de ação; } \\
\text { e na fase } 3 \text { implementa-se a ação proposta de maneira } \\
\text { integrada com a política empresarial. }\end{array}$ \\
\hline Sethi & $\begin{array}{l}\text { Dimensions of corporate } \\
\text { social performance. } \\
\text { California Management } \\
\text { Review, v. } 17, \text { p. } 58-64, \\
\quad 1975 .\end{array}$ & $\begin{array}{l}\text { Desenvolve o Esquema de Três Estados para Classificar as } \\
\text { Dimensões do Comportamento Corporativo classificando o } \\
\text { comportamento empresarial em três tipos: organizações } \\
\text { defensivas e reativa, organizações socialmente responsáveis e } \\
\text { organizações pró-ativas e responsivas. }\end{array}$ \\
\hline $\begin{array}{c}\text { Preston e } \\
\text { Post (1975) }\end{array}$ & $\begin{array}{l}\text { Private management and } \\
\text { public policy. California } \\
\text { Management Review. } \\
\text { Berkeley. v.23, n.3, p. } 56- \\
\quad \text { 62, spring } 1975 .\end{array}$ & $\begin{array}{l}\text { Definem duas áreas de gestão da responsabilidade social: o } \\
\text { envolvimento primário que compreende o comportamento e as } \\
\text { transações que derivam da característica e operação da } \\
\text { empresa e o envolvimento secundário, que inclui impactos e } \\
\text { feitos gerados por suas atividades primárias. }\end{array}$ \\
\hline $\begin{array}{c}\text { Zenisek } \\
\text { (1979) }\end{array}$ & $\begin{array}{l}\text { Corporate social } \\
\text { responsibility: a } \\
\text { conceptualization based on } \\
\text { organizational literature. } \\
\text { Academy of Management } \\
\text { Review, v. 4, n. 3, p. 359- } \\
\text { 368, jul, } 1979 .\end{array}$ & $\begin{array}{l}\text { Propõe que a definição de responsabilidade social corporativa } \\
\text { deve incluir a relação entre ideologia social, ideologia da } \\
\text { organização e seus aspectos operacionais em relação a } \\
\text { negócios éticos. Sugere ainda um conjunto de ações gerenciais } \\
\text { que podem ser divididas em quatro tipos. }\end{array}$ \\
\hline $\begin{array}{c}\text { Carroll } \\
\text { (1979) }\end{array}$ & $\begin{array}{l}\text { Three Dimensional } \\
\text { conceptual model } f \\
\text { corporate performance. } \\
\text { Academy of Management }\end{array}$ & $\begin{array}{l}\text { Desenvolvem o Modelo Conceitual Tridimensional de } \\
\text { Desempenho Social Corporativo e estabelece os componentes } \\
\text { da responsabilidade social - econômica, legal, ética e } \\
\text { discricionária - que foram reelaborados em } 1991 \text { e }\end{array}$ \\
\hline
\end{tabular}




\begin{tabular}{|c|c|c|}
\hline & $\begin{array}{c}\text { Review, v. 4, p. 497-505, } \\
1979 .\end{array}$ & organizados numa estrutura piramidal \\
\hline $\begin{array}{l}\text { Tuzzolino e } \\
\text { Armandi } \\
\text { (1981) }\end{array}$ & $\begin{array}{l}\text { A need-hierarchy framework } \\
\text { for assessing corporate } \\
\text { social responsibility. } \\
\text { Academy of Management } \\
\text { Review, v. 6, n. 1, p. 21-28, } \\
\text { 1981. }\end{array}$ & $\begin{array}{l}\text { Apresentam a Estrutura das Necessidades Hierárquicas para } \\
\text { Avaliar a Responsabilidade Social das Corporações, baseado } \\
\text { nas necessidades hierárquicas de Maslow. Desenvolvem ainda } \\
\text { um constructo taxonômico e um padrão de medida para } \\
\text { avaliar e monitorar o desempenho e a responsabilidade social. }\end{array}$ \\
\hline $\begin{array}{l}\text { Dalton e } \\
\text { Cosier } \\
(1982)\end{array}$ & $\begin{array}{l}\text { The four faces of social } \\
\text { responsibility. Business } \\
\text { Horizons, p. 19-27, } 1982 .\end{array}$ & $\begin{array}{l}\text { Propõem a ideia de "quatro faces" da responsabilidade social, } \\
\text { descritas em uma matriz } 2 \times 2 \text {. Nessa matriz podem ocorrer } \\
\text { várias combinações entre legalidade e responsabilidade, que } \\
\text { se ampliam em aspectos legal e ilegal de um lado e, do outro, } \\
\text { aspetos irresponsável e responsável. }\end{array}$ \\
\hline $\begin{array}{c}\text { Strand } \\
(1983)\end{array}$ & $\begin{array}{l}\text { A systems paradigm of } \\
\text { organizational adaptations } \\
\text { to the social environment. } \\
\text { Academy of Management } \\
\text { Review, v. 8, n. 1, p. } 90-96, \\
1983 .\end{array}$ & $\begin{array}{l}\text { Desenvolvem o Modelo de Sistemas de Responsabilidade } \\
\text { Social Organizacional focalizando a evolução do desempenho } \\
\text { social corporativo com base em três desafios, tais como: } \\
\text { responsabilidade econômica, responsabilidade pública e } \\
\text { responsabilidade social. }\end{array}$ \\
\hline $\begin{array}{l}\text { Car } \\
\text { Hoy }\end{array}$ & $\begin{array}{l}\text { Integrating corporate social } \\
\text { policy into strategic } \\
\text { management. } \\
\text { Journal of Business } \\
\text { Strategic, v. } 4, \text { n. } 3, \text { p. } 48-57, \\
1984 . \\
\end{array}$ & $\begin{array}{l}\text { Buscam integrar políticas sociais e gestão estratégica, } \\
\text { abrangendo elementos associados à competição dos negócios. } \\
\text { As dimensões retratadas incorporam uma política social de } \\
\text { macro visão que inclui os níveis da estratégia societal, } \\
\text { corporativo e negócios; e micro visão, relacionada a políticas } \\
\text { sociais funcionais e operacionais. }\end{array}$ \\
\hline $\begin{array}{l}\text { Wartick e } \\
\text { Cochran } \\
(\mathbf{1 9 8 5 )}\end{array}$ & $\begin{array}{l}\text { The evolution of the } \\
\text { corporate social } \\
\text { performance model. } \\
\text { Academy of Management } \\
\text { Review, v. 10, n. 4, p. } 758- \\
769,1985 .\end{array}$ & $\begin{array}{l}\text { Propõe um modelo de performance social corporativa avaliar } \\
\text { a evolução do desempenho social por meio de uma estrutura } \\
\text { constituída por princípios, processos e política, com base em } \\
\text { três desafios da RSC: responsabilidade econômica, } \\
\text { responsabilidade pública e responsividade social. }\end{array}$ \\
\hline $\begin{array}{r}\text { Car } \\
(19\end{array}$ & $\begin{array}{l}\text { The Pyramid of corporate } \\
\text { social responsibility. } \\
\text { Business Horizons. Vol. 34, } \\
\text { n. 4, p. 39-48, } 1991 .\end{array}$ & $\begin{array}{l}\text { Reelaboração do Modelo Conceitual Tridimensional de } \\
\text { Desempenho Social Corporativo proposto em 1979, } \\
\text { organizados numa estrutura piramidal - responsabilidade } \\
\text { econômica, legal, ética e discricionária. }\end{array}$ \\
\hline $\begin{array}{r}\text { Wood } \\
(\mathbf{1 9 9 1 )}\end{array}$ & $\begin{array}{l}\text { Corporate social } \\
\text { performance revisited. } \\
\text { Academy of Management } \\
\text { Review, v.16, n.4, p. } 691- \\
\quad 718,1991 .\end{array}$ & $\begin{array}{l}\text { Desenvolveu um Modelo de Performance Social Corporativa } \\
\text { como sendo a configuração de uma organização em termos de: } \\
\text { princípios de responsabilidade social corporativa, processos de } \\
\text { responsividade social corporativa e resultados sociais } \\
\text { corporativos. Os princípios são expressos em três níveis: } \\
\text { institucional - legitimidade da empresa; organizacional - } \\
\text { responsabilidade pública; e individual - arbítrio gerencial. }\end{array}$ \\
\hline $\begin{array}{r}\text { Sw } \\
(1\end{array}$ & $\begin{array}{c}\text { Addressing a theoretical } \\
\text { problem by reorienting the } \\
\text { corporate social } \\
\text { performance model. } \\
\text { Academy of Management } \\
\text { Review, v. 20, n. 1, p. 43-64, } \\
1995 .\end{array}$ & $\begin{array}{l}\text { Toma como base a estrutura de Wood (1991) e propõe um } \\
\text { aperfeiçoamento, integrando perspectivas econômicas e } \\
\text { normativas aos princípios de responsabilidade social } \\
\text { corporativa. Apresenta uma visão ampliada das relações de } \\
\text { troca da corporação com a sociedade, incluindo valores éticos. }\end{array}$ \\
\hline $\begin{array}{l}\text { End } \\
\text { Tavis }\end{array}$ & $\begin{array}{c}\text { A balanced concept of the } \\
\text { firm and the measurement of } \\
\text { its longterm } \\
\text { planning and peformance. } \\
\text { Journal of Business Ethics, } \\
\text { v. 17, n. 11, p. 1129-1144, } \\
\text { Aug. } \\
1998 .\end{array}$ & $\begin{array}{l}\text { Propõem um modelo conceitual em que as responsabilidades } \\
\text { corporativas, analisadas em função das dimensões econômica, } \\
\text { social e ambiental, devem ser consideradas em três níveis } \\
\text { éticos: o primeiro nível refere-se a maximizar o lucro; o } \\
\text { segundo, a promover o bem-estar social, e o terceiro nível, a } \\
\text { estreitar relações da empresa com as demandas da sociedade. } \\
\text { Essa perspectiva foi adotada por Elkington (2001). }\end{array}$ \\
\hline $\begin{array}{l}\text { Quazi e } \\
\text { O'Brien } \\
(\mathbf{2 0 0 0 )}\end{array}$ & $\begin{array}{l}\text { An empirical test of a Cross- } \\
\text { National Model of } \\
\text { Corporate Social }\end{array}$ & $\begin{array}{l}\text { Apresentam o Modelo Bidimensional de Responsabilidade } \\
\text { Social Corporativa, classificando-a em ampla e restrita. A } \\
\text { contribuição do modelo bidimensional está no fato de que a }\end{array}$ \\
\hline
\end{tabular}




\begin{tabular}{|c|c|c|}
\hline & $\begin{array}{c}\text { Responsibility. Journal of } \\
\text { Business Ethics. } \\
\text { Netherlands: Kluwer } \\
\text { Academic Publishers, v. } \\
\text { 25, p. 33-51, 2000. }\end{array}$ & $\begin{array}{l}\text { responsabilidade empresarial é avaliada a partir da perspectiva } \\
\text { de seus custos, podendo ser enquadrada em quatro quadrantes } \\
\text { distintos - visão filantrópica, clássica, socioeconômica e } \\
\text { moderna. }\end{array}$ \\
\hline $\begin{array}{l}\text { Schwartz e } \\
\text { Carroll } \\
(2003)\end{array}$ & $\begin{array}{c}\text { Corporate Social } \\
\text { Responsibility: a three- } \\
\text { domain approach. Business } \\
\text { Ethics Quarterly, v. } 13, \text { I.4, } \\
\text { p. } 503-530,2003 .\end{array}$ & $\begin{array}{l}\text { Desenvolveram o Modelo de Três Dimensões da } \\
\text { Responsabilidade Social Corporativa, baseado em modelo } \\
\text { anterior proposto por Carroll (1991). É composto por três } \\
\text { dimensões centrais da RSC - econômica, legal, e ética - que } \\
\text { são dispostas em um diagrama, ampliando-se em sete } \\
\text { categorias. A filantropia deixa de ser uma perspectiva de } \\
\text { destaque. }\end{array}$ \\
\hline $\begin{array}{l}\text { Porter e } \\
\text { Kramer } \\
(2006)\end{array}$ & $\begin{array}{c}\text { Estratégia e sociedade: o elo } \\
\text { entre a vantagem } \\
\text { competitiva e a } \\
\text { responsabilidade social } \\
\text { empresarial. Harvard } \\
\text { Business Review. Elsevier, } \\
\text { v. } 84, \text { n.12, p. } 78- \\
92,2006 .\end{array}$ & $\begin{array}{l}\text { Apresenta uma construção de valor compartilhado entre a } \\
\text { empresa e a sociedade. Essa estrutura é composta por duas } \\
\text { dimensões, a "de dentro para fora" e a "de fora para dentro". } \\
\text { A primeira dimensão discute a integração das atividades de } \\
\text { responsabilidade social a cadeia de valor. Já a segunda } \\
\text { dimensão aborda a importância da questão social para a } \\
\text { estratégia da organização. }\end{array}$ \\
\hline $\begin{array}{l}\text { Schwartz e } \\
\text { Carroll } \\
(2007)\end{array}$ & $\begin{array}{c}\text { Integrating and Unifying } \\
\text { Competing and } \\
\text { Complementary } \\
\text { Frameworks: The Search for } \\
\text { a Common Core in the } \\
\text { Business and Society Field. } \\
\text { Business \& Society, v. 20, n. } \\
\text { 10, pp. 1-39, Sep. } 2007 .\end{array}$ & $\begin{array}{l}\text { Propõem o Modelo VBA (value, balance, accountability) que } \\
\text { apresenta um diagrama com cinco temas reconhecidos pelos } \\
\text { autores como complementares e interdependentes } \\
\text { (responsabilidade social corporativa, ética empresarial, } \\
\text { administração dos stakeholders, sustentabilidade e cidadania } \\
\text { corporativa) unidos por meio de três conceitos centrais (valor, } \\
\text { equilíbrio e responsabilidade). }\end{array}$ \\
\hline
\end{tabular}

FONTE: baseado em BAKKER et al, 2005; FREIRE et al, 2009; WELZEL, 2009.

É interessante observar que nos últimos anos tem-se destacado proposições teóricas que buscam conciliar o comportamento socioambientalmente responsável das empresas com o incremento da competitividade do negócio (HART, 2006; ZADEK, 2004; PORTER; KRAMER, 2006). Tal ideia já estava presente nos trabalhos desenvolvidos por Ackerman (1973), Carrol e Hoy (1984) e Drucker (1995 e 1996), que apresentavam um posicionamento bem definido em relação ao envolvimento das empresas com práticas e políticas socioambientais. Nas obras, os autores lembram que um dos conceitos mais antigos da administração refere-se ao foco do negócio. Drucker (1995), ao externar tal pensamento, afirma que as organizações não devem atuar em questões socioambientais nas quais não têm competência. Isso não quer dizer que o autor seja contra a empresa assumir um papel social, mas que a organização deve agir levando em consideração o seu contexto competitivo.

As organizações podem prejudicar a si mesmas, ao se dedicarem a tarefas que estão além de sua competência especializada, dos seus valores especializados, das suas funções especializadas (...) as causas são certamente boas e exigem ação. Mas a ação necessária - ou pelo menos a ação escolhida por essas várias organizações - estavam além do foco e da função delas e totalmente fora da sua competência (DRUCKER, 1995, p.70). 
Porter e Kramer (2006) resgatam essa visão de integração das práticas da responsabilidade social à estratégia competitiva, em artigo publicado na Harvard Business Review, afirmando que:

(...) as abordagens dominantes à RSE são tão fragmentadas e desvinculadas da empresa e da estratégia que ocultam muitas das grandes oportunidades para que a empresa beneficie a sociedade. Já se analisasse suas perspectivas no campo da responsabilidade social usando os mesmos arcabouços que norteiam suas principais decisões empresariais, a empresa descobriria que a RSE pode ser mais do que um custo, um entrave ou uma ação filantrópica - pode ser fonte de oportunidades, inovação e vantagem competitiva. (p. 54).

Dessa forma, propõem um modelo que busca a integração entre comportamento socioambientalmente responsável e vantagem competitiva. Para tanto, defendem a necessidade de avaliar o contexto competitivo de cada organização e classificar as questões em uma das três dimensões:

- Questões Sociais Genéricas: podem ser importantes para a sociedade, mas não são significativamente afetadas pelas operações da empresa nem influenciam sua competitividade a longo prazo;

- Impactos Sociais da Cadeia de Valor: questões que são significativamente afetadas pelas atividades da empresa no curso normal das operações; e

- Dimensões Sociais do Contexto Competitivo: fatores do ambiente externo que afetam a competitividade da empresa nos locais onde opera.

Porter e Kramer (2006) ainda avançam no modelo, conforme Figura 6, destacando a importância de priorizar as questões, segmentando as possíveis ações no que denominam de responsabilidade social responsiva e responsabilidade social estratégica. A primeira consiste em atuar como bom cidadão corporativo mitigando os impactos adversos da atividade da empresa. Já a segunda implica em fazer algo distinto das adversárias para cortar custos, ou melhor atender certas necessidades dos clientes, isto é, identificar oportunidades de valor compartilhado. 


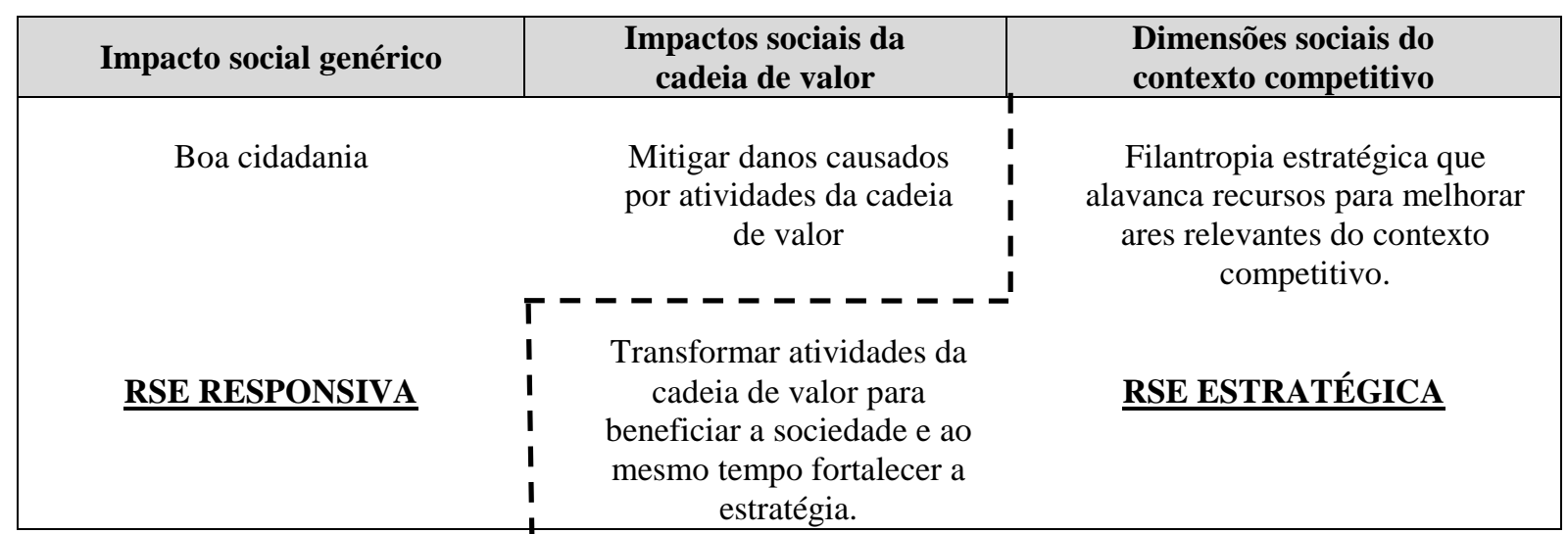

Figura 6 - Envolvimento da empresa na sociedade: abordagem estratégica FONTE: PORTER; KRAMER, 2006, p.63.

Portanto, para Porter e Kramer (2006), o teste essencial para nortear o envolvimento de uma empresa com questões socioambientais, não é se a causa é digna, mas se traz a oportunidade de agregar valor compartilhado, isto é, benefícios para a empresa e também para a sociedade, o que denominaram de responsabilidade social estratégica. A cadeia de valor é utilizada pelos autores como arcabouço para identificar o impacto social das atividades e conduzir as ações. Isto porque, na visão dos autores:

\footnotetext{
Nenhuma empresa pode resolver todos os problemas da sociedade nem arcar com o custo que isso traria. Em vez disso, cada empresa deve se concentrar em questões que tenham alguma interseção com sua área de atuação. É melhor deixar outras causas para empresas de outros setores, ONGs ou instituições públicas em melhor posição para enfrentá-las. (PORTER; KRAMER, 2006, p. 59)
}

Entretanto, os autores não apresentam quais ferramentas e práticas de gestão poderiam ser utilizadas pelo gestor, em cada nível de proposição, para alavancar o envolvimento socioambiental.

A proposição de Zadek (2004) para conciliar o comportamento socioambientalmente responsável com o melhor desempenho competitivo não aborda a relação da ação com o foco do negócio, mas vincula ao grau de maturidade da sociedade para o assunto e a forma de interação da empresa.

O grau de exigência e maturidade da sociedade para com os problemas socioambientais é entendido pelo autor a partir de uma ferramenta, em escala, desenvolvida pelo laboratório farmacêutico Novo Nordisk, que busca classificar as expectativas do público a respeito do tema - disponível no Quadro 7. Zadek (2004) afirma que quanto mais presente se torna a 
questão no contexto, mais a empresa precisa avançar em relação as suas práticas para evitar riscos ao negócio e tirar proveito de novas oportunidades.

Quadro 7- Os quatro estágios da maturidade de questões socioambientais

\begin{tabular}{|c|c|}
\hline LATENTE & $\begin{array}{l}\text { - Comunidades de atividades estão cientes da questão social. } \\
\text { - Evidência científica é débil. } \\
\text { - Questão é amplamente ignorada ou descartada pela comunidade } \\
\text { empresarial. }\end{array}$ \\
\hline EMERGENTE & $\begin{array}{l}\text { - Há consciência política e da imprensa sobre a questão societal. } \\
\text { - Começa a surgir um corpo de pesquisa, mas dados ainda são frágeis. } \\
\text { - Empresas pioneiras testam abordagens para enfrentar a questão. }\end{array}$ \\
\hline CONSOLIDAÇÃO & $\begin{array}{l}\text { - Começa a surgir um corpo de práticas empresariais em torno da } \\
\text { - } \text { - Sãostão societal. } \\
\text { - Há litígio e uma crescente percepção da necessidade de legislação. } \\
\text { - São criados padrões voluntários e ocorre uma ação coletiva. }\end{array}$ \\
\hline INSTITUCIONALIZADO & $\begin{array}{l}\text { - É adotada uma legislação ou normas empresariais. } \\
\text { - Práticas incultadas tornam-se parte integrante do modelo de } \\
\text { excelência empresarial. }\end{array}$ \\
\hline
\end{tabular}

FONTE: ZADEK, 2004, p.45.

Já a forma de atuação da empresa é entendida pelo autor como trajetórias de aprendizado organizacional, sendo descrita em cinco estágios, conforme o Quadro 8. Zadek (2004, p. 44) afirma que: "Para a empresa, o segredo é, portanto, conseguir prever e dar uma resposta credível à consciência mutante da sociedade em relação a certas questões."

Quadro 8 - Os cinco estágios do aprendizado organizacional

\begin{tabular}{|c|c|c|}
\hline Estágio & Como atua a organização & Por que age assim \\
\hline $\begin{array}{c}\text { Defensivo } \\
\text { Não cabe a nós resolver } \\
\text { isso." }\end{array}$ & $\begin{array}{c}\text { Nega práticas, impactos, } \\
\text { consequências e } \\
\text { responsabilidades. }\end{array}$ & $\begin{array}{c}\text { Para se defender de ataques a sua reputação } \\
\text { capazes de, no curto prazo, afetar vendas, } \\
\text { recrutamento, produtividade e marca. }\end{array}$ \\
\hline $\begin{array}{c}\text { Conformidade } \\
\text { "Faremos só o estritamente } \\
\text { necessário." }\end{array}$ & $\begin{array}{c}\text { Adota abordagem formal de } \\
\text { conformidade como um custo } \\
\text { para operar. }\end{array}$ & $\begin{array}{c}\text { Para mitigar a erosão do valor econômico } \\
\text { no médio prazo em virtude de risco } \\
\text { constante de litígio e de danos à reputação. }\end{array}$ \\
$\begin{array}{c}\text { Gerencial } \\
\text { "O problema está na }\end{array}$ & $\begin{array}{c}\text { Insere a questão societal em } \\
\text { seus principais processos } \\
\text { gerenciais. }\end{array}$ & $\begin{array}{c}\text { Para mitigar a erosão do valor econômico } \\
\text { no médio prazo e obter ganhos de mais } \\
\text { longo prazo com a integração de práticas de } \\
\text { negócios responsáveis a operações } \\
\text { cotidianas. }\end{array}$ \\
\hline $\begin{array}{c}\text { Estratégico } \\
\text { "Isso nos traz uma vantagem } \\
\text { competitiva" }\end{array}$ & $\begin{array}{c}\text { Integra a questão societal às } \\
\text { principais estratégias de } \\
\text { negócio. }\end{array}$ & $\begin{array}{c}\text { Para reforçar o valor econômico no longo } \\
\text { prazo e garantir a vantagem do pioneirismo, } \\
\text { alinhando inovaçóes de estratégia e } \\
\text { processo à questão societal. }\end{array}$ \\
\hline $\begin{array}{c}\text { Civil } \\
\text { "Precisamos garantir que } \\
\text { todos ajam assim" }\end{array}$ & $\begin{array}{c}\text { Promove ampla participação } \\
\text { do setor na responsabilidade } \\
\text { empresarial. }\end{array}$ & $\begin{array}{c}\text { Para reforçar o valor econômico no longo } \\
\text { prazo, superando quaisquer desvantagens do } \\
\text { pioneirismo, e extrair ganhos por meio da } \\
\text { ação coletiva. }\end{array}$ \\
\hline
\end{tabular}

FONTE: ZADEK; 2004, p .44. 
A partir dessas duas perspectivas, Zadek (2004) propõe uma ferramenta, na forma de gráfico, para ajudar a empresa a decidir como desenvolver-se e posicionar-se nas suas futuras estratégias para ganhar a aceitação do mercado. Entretanto, uma possível limitação do modelo é que ele não apresenta sugestões de ferramentas, e ações organizacionais podem ser utilizadas pela empresa para medir sua posição atual e avançar na gestão socioambiental.

Uma outra proposição foi apresentada por Hart (2006) como um aprimoramento do modelo de valor apresentado por Hart e Milstein (2003). A perspectiva teórica é estruturada em quatro dimensões, conforme apresentado na Figura 7.

No eixo vertical, o autor destaca a necessidade das empresas administrarem os resultados de curto prazo simultaneamente com a geração de oportunidades futuras. Já o eixo horizontal avalia a proteção de habilidades organizacionais internas concomitantemente com a inserção de novas perspectivas e conhecimento advindos dos stakeholders.

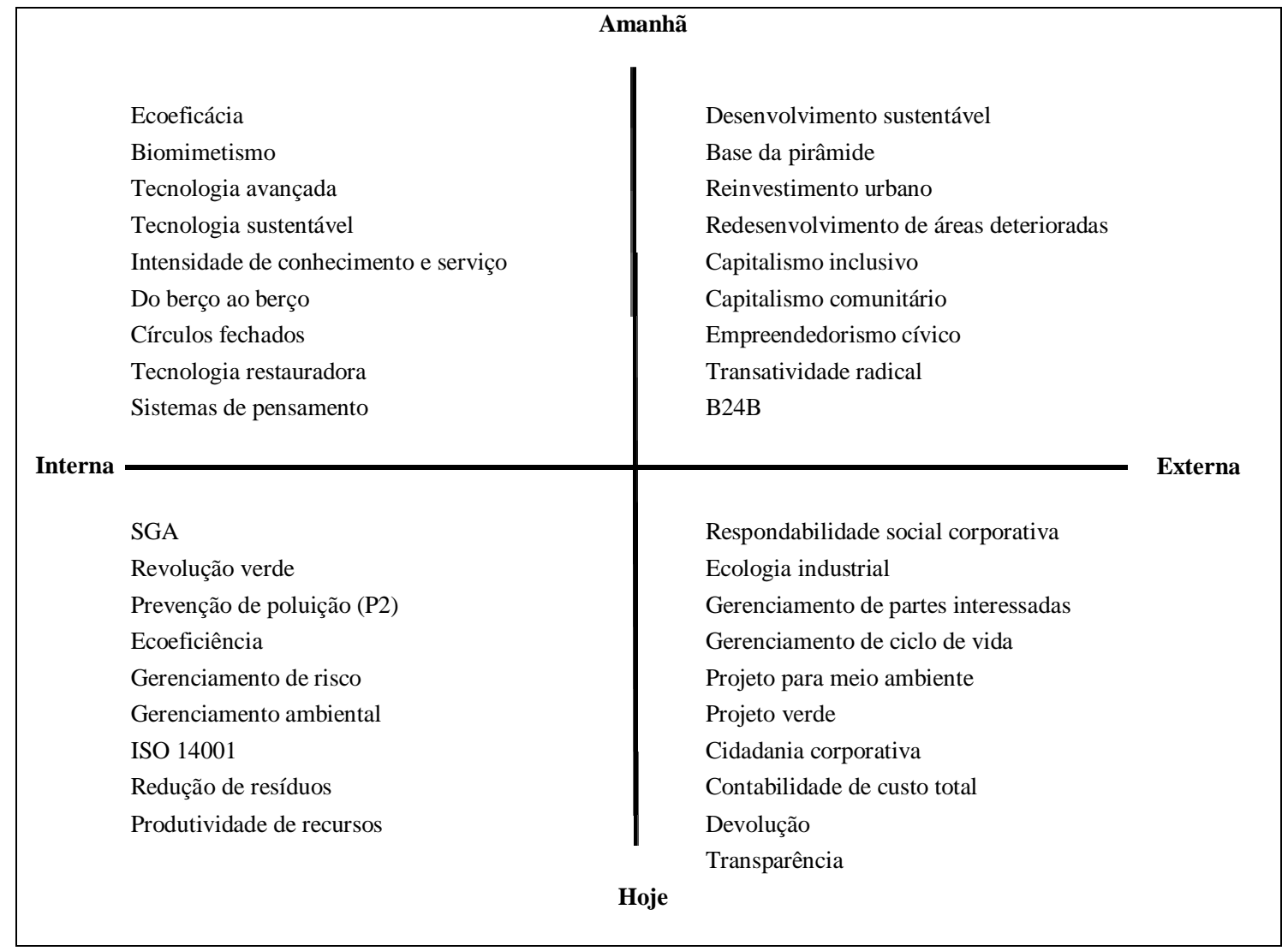


Portanto, o quadrante inferior esquerdo foca-se nos aspectos de desempenho interno de curto prazo, buscando redução de custos e riscos para o negócio a partir da eficiência de recursos e da prevenção da poluição. Já o quadrante inferior direito, embora também se concentre em dimensões de desempenho de natureza semelhante, busca fomentar a relação da empresa com partes interessadas externas, especificamente, a cadeia de valor imediata, envolvendo transparência e administração do ciclo de vida.

O quadrante superior esquerdo aborda a atenção na geração de produtos e serviços para o futuro, o que implica em adquirir habilidades, competência e tecnologia que a reposicione para o crescimento. Por fim, o quadrante superior direito se dirige para a necessidade de identificar novos produtos aos clientes já existentes, ou então, que a empresa chegue a mercados anteriormente não atendidos. Assim, o desenvolvimento social e a criação de riqueza entre os países mais pobres do mundo são aspectos relevantes para esse quadrante.

Hart (2006) entende que a sustentabilidade é um conceito multidimensional que não pode ser abordado por uma única ação corporativa. Portanto, afirma que: “As empresas devem ter um bom desempenho nos quatro quadrantes do modelo se quiserem continuar gerando valor." (p. 81). Entretanto, o autor acredita que apenas algumas poucas empresas serão capazes de executar de forma bem-sucedida as atividades nestas quatro perspectivas.

Pode-se afirmar que o modelo teórico proposto por Hart (2006) apesar de classificar as ferramentas para gestão da sustentabilidade em grupos que possibilitam alcançar objetivos empresariais específicos, não indica quais delas seriam mais efetivas, ou teriam seu potencial ampliado, se utilizadas de forma conjugada.

Observa-se, a partir dos diversos modelos propostos, que a internalização das práticas socioambientais como meio para tornar a organização mais sustentável pode ser feita de muitos modos. Nesta tese, acredita-se, conforme já proposto por Jennings e Zandbergen (1995) que as empresa capazes de incorporar iniciativas socioambientais a sua estrutura organizacional, criam um sistema orgânico no qual há sinergia entre os sistemas estratégicos, os sistemas operacionais e o ambiente externo, tornando-os mais conectados e sustentáveis.

Todavia, o amplo espectro e a natureza interdisciplinar que permeiam as atividades têm levado muitas empresas a começar com a criação de uma força-tarefa composta por pessoas 
de diversos cargos, área de atuação e níveis hierárquicos (SAVITZ, 2007). Outras optam por áreas organizacionais específicas e dedicadas ao assunto.

No que se refere à estruturação interna da gestão socioambiental, muitos autores têm compartilhado da visão de Barbieri e Cajazeira (2009, p. 213) de que:

Cada organização deve encontrar o que lhe é mais conveniente de acordo com o seu porte, os produtos que oferece, as atividades que realiza, o seu entorno físico e social e suas partes interessadas. Porém, em todos os casos, o sucesso dessa empreitada depende sempre do compromisso efetivo da alta direção.

Savitz (2007) contribui com a discussão e defende uma perspectiva pouco enfatizada pelos autores da área de que a adoção de incentivos financeiros aos executivos para o desenvolvimento e observância das práticas socioambientais é um relevante fator para potencializar o equilíbrio de objetivos financeiros e não financeiros, despertando maior interesse pela sustentabilidade no nível executivo. Nas palavras do próprio autor: "Indicação inequívoca de que a mensagem está impregnando todo o mundo empresarial ocorrerá quando a remuneração dos CEOs for vinculada, como prática rotineira, ao desempenho não só financeiro, mas também ambiental - ou seja, o Tríplice Resultado.” (p. 72).

A partir das diversas discussões apresentadas neste capítulo, pode-se inferir que, para continuar no mercado, as empresas precisam adotar uma nova forma de conduta e estruturação. Portanto, pode-se dizer que o comportamento sociambientalmente responsável traz desafios, pois precisam ser racionalmente inseridos na gestão, pensados em relação aos impactos do negócio no ambiente e incorporados nos processos internos, avaliados considerando os objetivos estratégicos e os benefícios para a sociedade, alinhados com a cultura empresarial, motivados entre os lideres da organização e medidos para permitir a comparação da evolução da empresa ao longo do tempo. Tudo isso implica em reestruturação da empresa, mobilizando recursos internos para transferir e desenvolver o ambiente em que atua. E, qualquer que seja a teoria que venha a ser adotada por um gestor, sempre haverá dificuldade de implantar as proposições teóricas em razão da diversidade de questões e variadas expectativas dos diferentes públicos que se relacionam com a empresa. 


\subsection{Síntese dos Conceitos Relevantes}

Para facilitar o entendimento da diretriz teórica utilizada nesta tese, segue o Quadro 9 que apresenta um resumo dos principais conceitos descritos neste capítulo.

Quadro 9 - Diretriz teórica e conceitos relevantes para a pesquisa

\begin{tabular}{|c|c|c|}
\hline Diretriz Teórica & Conceitos Relevantes & Principais Autores \\
\hline \multirow{2}{*}{$\begin{array}{c}\text { Desenvolvimento } \\
\text { Sustentável }\end{array}$} & Surgimento do conceito & $\begin{array}{l}\text { Loyola (1997); Veiga (2008); Amazonas (2002); Brundtland } \\
\text { (1988). }\end{array}$ \\
\hline & $\begin{array}{l}\text { Perspectivas econômicas e o } \\
\text { desenvolvimento sustentável }\end{array}$ & $\begin{array}{l}\text { Cavalcanti (2003b); Loyola (1997); Veiga (2007); Sachs } \\
\text { (2007); Andrade e Romeiro (2009); Solow (2000). }\end{array}$ \\
\hline \multirow{3}{*}{$\begin{array}{l}\text { Economia } \\
\text { Ecológica }\end{array}$} & Conceito de Ecologia & Odum (1997); Odum e Odum (2001); Odum e Barrett (2008). \\
\hline & $\begin{array}{l}\text { Conceito e Princípios da } \\
\text { Economia Ecológica }\end{array}$ & $\begin{array}{l}\text { Baumgärtner e Quaas (2010); Amazonas (2002); Loyola } \\
\text { (1997); Cechin e Veiga (2010); Romeiro (2003), Müller } \\
\text { (2005). }\end{array}$ \\
\hline & $\begin{array}{c}\text { Entendimentos para o } \\
\text { desenvolvimento sustentável }\end{array}$ & Boulding (1966); Georgescu-Roegen (1971); Daly (1980). \\
\hline \multirow{4}{*}{$\begin{array}{l}\text { Princípios } \\
\text { Ecológicos }\end{array}$} & $\begin{array}{l}\text { Sustentabilidade da Economia a } \\
\text { partir da Ecologia }\end{array}$ & $\begin{array}{l}\text { Norton (1995); Odum e Odum (2001); Cavalcanti (2003b); } \\
\text { Constanza (1991); Daly e Torunsend (1993); Egri e Pinfield } \\
\text { (1998); Odum e Barrett (2008); Sachs (2007). }\end{array}$ \\
\hline & $\begin{array}{l}\text { Conceituação e descrição dos } \\
\text { princípios ecológicos }\end{array}$ & Capra $(1997,2002,2006)$. \\
\hline & $\begin{array}{l}\text { Aplicação dos princípios } \\
\text { ecológicos nas empresas }\end{array}$ & $\begin{array}{l}\text { Müeller (2007); Hawken et al (2000); Sachs (2007); Odum e } \\
\text { Barrett (2008). }\end{array}$ \\
\hline & $\begin{array}{c}\text { Concepções filosóficas de } \\
\text { suporte e a ecologia profunda }\end{array}$ & $\begin{array}{l}\text { Jonas (1979); Ferry (1994); Laszlo (2001); Campos (2008); } \\
\text { Naess (1973); Devall (2001); Capra (1987, } 1997 \text { e 2002). }\end{array}$ \\
\hline \multirow{2}{*}{$\begin{array}{l}\text { Responsabilidade } \\
\text { Socioambiental } \\
\text { do Negócio }\end{array}$} & Surgimento e contextualização & $\begin{array}{l}\text { Claro et al (2008); Elkington (2001); Kotler et al (2010); } \\
\text { Savitz (2007); Borger (2004). }\end{array}$ \\
\hline & $\begin{array}{c}\text { Evolução e diferentes } \\
\text { entendimentos de } \\
\text { responsabilidade socioambiental }\end{array}$ & $\begin{array}{l}\text { Garriga e Melé (2004); Johnson (1971), Davis (1967), Steiner } \\
\text { (1971), Eells e Walton (1974), Sethi (1975), Preston e Post } \\
\text { (1975) e Carroll (1979); Schwartz e Carroll (2003). }\end{array}$ \\
\hline \multirow{5}{*}{$\begin{array}{l}\text { Sustentabilidade } \\
\text { do Negócio }\end{array}$} & $\begin{array}{l}\text { Relação entre DS e } \\
\text { responsabilidade socioambiental } \\
\text { da empresa. }\end{array}$ & $\begin{array}{l}\text { Barbieri e Cajazeira (2009); Savitz (2007); Aligleri et al } \\
\text { (2009); Nascimento et al (2008); Scharf (2004); Furtado } \\
\text { (2004). }\end{array}$ \\
\hline & Conceito de Triple bottom line & Elkington (2001); Savitz (2007). \\
\hline & $\begin{array}{l}\text { Conceito e Gestão dos } \\
\text { stakeholders }\end{array}$ & $\begin{array}{l}\text { Freeman (1984); Silva (2006); Donaldson e Preston (2002); } \\
\text { Stoner e Freeman (1995); Hitt et al (2002); Zadek (1998). }\end{array}$ \\
\hline & $\begin{array}{l}\text { Princípios diretivos e } \\
\text { instrumentos de gestão }\end{array}$ & $\begin{array}{l}\text { Barbieri e Cajazeira (2009); Louette (2007); Instituto Ethos } \\
\text { (2007); IBCG (2007). }\end{array}$ \\
\hline & Modelos de gestão & $\begin{array}{l}\text { Bakker et al (2007); Freire et al (2009); Welzel (2009); } \\
\text { Porter e Kramer (2006); Hart (2006); Zadek (2004). }\end{array}$ \\
\hline
\end{tabular}




\section{METODOLOGIA DE PESQUISA}

Conforme já apresentado anteriormente, o problema desta pesquisa é: "Qual é a relação entre o uso de ferramentas de gestão para a sustentabilidade e a adoção dos princípios ecológicos pelas empresas?" Desta forma, pode-se dizer que o mesmo está coerente com as condições apresentadas por Kerlinger (1980) que define três condições para a sua definição: expressar uma relação entre duas ou mais variáveis, ser apresentado na forma interrogativa e possibilitar o teste empírico.

Assim, para conhecer as interações existentes entre algumas ferramentas de gestão para a sustentabilidade e a adoção dos princípios ecológicos pelas empresas, este capítulo, estruturado em seis seções, apresenta o delineamento metodológico do estudo. Destaca, portanto, a caracterização do método de pesquisa adotado, a definição do universo e da amostra, o modelo teórico conceitual, o instrumento de pesquisa utilizado, as técnicas e processos para o tratamento dos dados e as limitações da pesquisa.

\subsection{Caracterização da Pesquisa}

Sampieri et al (2006) afirmam que dois fatores determinam o tipo de estudo a ser desenvolvido em uma pesquisa: o estado de conhecimento em relação ao assunto investigado e o enfoque que o pesquisador pretende dar ao estudo. Dessa forma, esta pesquisa pode ser tipificada como descritiva e correlacional com enfoque quantitativo e de caráter interdisciplinar. Descritiva, uma vez que pretende relatar propriedades e características do fenômeno em análise, isto é, retratar as associações entre ferramentas de gestão para a sustentabilidade e princípios ecológicos. Correlacional, visto que pretende identificar como se relacionam duas variáveis em um determinado contexto. Ferramentas de gestão para a sustentabilidade e princípios ecológicos, consideradas variáveis de pesquisa, serão analisadas buscando encontrar ligações coerentes e sistemáticas entre elas, sem conotação de causa e efeito. Tal correlação, conforme Sampieri et al (2006), pode ser:

a) positiva, quando existem casos com altos valores entre uma ou ambas variáveis;

b) negativa, quando se encontram casos com altos valores em uma variável e baixos valores em outra e, ainda; 
c) a possibilidade de inexistência de correlação, em que não se observa um padrão de relação entre as variáveis analisadas, dificultando um prognóstico de comportamento.

Neste sentido, os autores destacam que saber como se comporta um conceito conhecendo o comportamento de variáveis relacionadas tem valor explicativo, ainda que parcial. (Ibid., p. 104)

Dessa forma, o estudo busca identificar, conforme destacado por Hair et al (2005, p. 310311):

a) a presença da relação, baseado no conceito de significância estatística;

b) a natureza da relação, identificando o modo como as variáveis se relacionam, podendo ser caracterizada como linear ou não-linear e;

c) a força da associação, o que implica em medir cada uma das variáveis e também as relações entre elas.

A opção por um estudo de natureza correlacional, ao invés de causal, está embasada no argumento de Morgan (1996, p. 260) ao afirmar que: "Concepções em termos da causalidade simples são totalmente inadequadas para a compreensão da dinâmica de sistemas complexos, há sempre causas que fazem com que causas causem outras causas."

Para a construção deste trabalho foi considerado como premissa metodológica de que há uma realidade com propriedades objetivas a conhecer, que pode ser captada com a medição e quantificação. Dessa forma, seguiram-se as etapas propostas por Sampieri et al (2006), na seguinte ordem:

a) A partir do arcabouço conceitual, delinearam-se ideias e delas desenvolveu-se a questão de pesquisa que se tornaram hipóteses.

b) As hipóteses são submetidas à prova a partir de um modelo de pesquisa e um instrumento de medição padronizado.

c) As medições obtidas, transformadas em valores numéricos, são analisadas utilizando-se de métodos estatísticos na busca de explicações.

Portanto, a investigação tem um enfoque quantitativo já que propõe medir variáveis envolvidas, confiando na medição numérica para estabelecer padrões de comportamento e interação de uma população. 
Caracterizada como interdisciplinar, pois envolve a articulação de teorias advindas de diferentes áreas do conhecimento:

a) o desenvolvimento sustentável estudado pelas ciências econômicas;

b) a gestão sustentável, foco de análise da administração de empresas e;

c) os princípios ecológicos relacionados à biologia, em especial ao ramo da ecologia.

O modelo de pesquisa pode ser classificado como não-experimental, uma vez que, conforme explicitado por Sampieri et al (2006), observa-se situações já existentes, não provocadas intencionalmente pelo pesquisador. Os indivíduos já pertenciam a um grupo ou nível determinado da variável resposta por auto-escolha, não sendo possível manipulá-las ou influílas, conforme apresentado com mais detalhes nas próximas seções deste capítulo.

\subsection{Definição do Universo e da Amostra}

O universo da pesquisa, também chamado de população por Saunders et al (2007, p. 204), corresponde ao "[...] conjunto total de casos ou membros do qual se extrai uma amostra." Dessa forma, foi considerado como universo de estudo as empresas envolvidas com gestão socioambientalmente responsáveis no Brasil. Portanto, o sujeito da pesquisa é a empresa, e a amostra objetivou incluir o maior número possível de firmas no estudo.

Na definição da estratégia de pesquisa, foram considerados os relatos de Mancini (2008) e Hrdlicka (2009), em estudos envolvendo empresas, que destacam dificuldades como o complicado acesso aos gestores nas empresas; o árduo esforço para cativá-los a colaborar com a pesquisa; a pequena autonomia dos respondentes, que nem sempre tem autorização para fornecer dados da empresa; a recusa em participar da pesquisa alegando confidencialidade das informações, acarretando, por consequência, o baixo retorno de respostas.

Optou-se, portanto, por não realizar a coleta de dados primários envolvendo gestores de empresas. A estratégia implicou em identificar quais bancos de dados existiam com o propósito de acompanhar a incorporação as ferramentas de gestão socioambientais desenvolvidas pelas empresas no Brasil. Acredita-se que o acesso a um banco de dados já 
consolidado reduz as dificuldades de obtenção das informações, considerado o principal entrave para a viabilidade dos estudos por muitos pesquisadores.

Numa sondagem preliminar foram identificados três bancos de dados que poderiam ser utilizados como fonte de informações para este estudo. Dessa forma, conforme destacado por Giovannini (2008), torna-se necessário avaliar a adequação do banco de dados para uma análise estatisticamente robusta e adequada. Entre as possíveis fontes de informação existentes estão:

a) Compêndio de relatórios de empresas que se utilizam do modelo Global Reporting Initiative (GRI): disponível na internet e formado por empresas que utilizam o padrão GRI como modelo para a construção do relatório de desempenho http://www.globalreporting.org/GRIReports/GRIReportsList. A disponibilização dos relatórios por parte das empresas é voluntária e os dados têm uso livre para pesquisas. Um total de 67 empresas brasileiras publicou seu relatório, referente ao ano de 2008, utilizando o modelo GRI. Atualizado anualmente.

b) Banco de dados dos Indicadores Ethos de Responsabilidade Social: composto por empresas que responderam voluntariamente ao questionário dos Indicadores Ethos e que buscam avaliar o seu comprometimento com responsabilidade socioambiental. Todos os anos mais de 500 empresas instaladas no Brasil buscam esse instrumento como forma de qualificar suas práticas. A participação das empresas na resposta aos Indicadores Ethos é voluntária e não implica em pagamento de taxas ou custos; e

c) Banco de dados do Índice de Sustentabilidade Empresarial (ISE) da BM\&FBovespa: o ISE é formado por empresas listadas na BM\&FBovespa e busca avaliar a performance das empresas listadas na BOVESPA com relação aos aspectos de sustentabilidade. São convidadas a responder o questionário de avaliação as 150 empresas emissoras das ações mais líquidas no período analisado. O aceite ao convite implica no pagamento de taxas. Atualizado anualmente.

A escolha recaiu sobre os Indicadores Ethos, tendo em vista o grau de robustez aparente, a estabilidade do instrumento e a conveniência da pesquisadora. Também porque possui maior número de empresas em seu banco de dados e permite, a partir das questões propostas no questionário, inferir sobre as variáveis definidas para este estudo. 
Foi realizado um contato inicial com a coordenadora responsável pelos Indicadores Ethos, conforme Apêndice 1. O Instituto gentilmente se dispôs a colaborar com a pesquisa cedendo o banco de dados completo das empresas que responderam aos Indicadores Ethos no ano de 2008, num total de 673 empresas, mediante o compromisso de confidencialidade das informações cedidas e uso exclusivamente acadêmico. Os dados, sem a identificação das empresas respondentes, foram encaminhados por e-mail em uma matriz do programa Microsoft Excel com 492.678 linhas por 5 colunas.

A participação das empresas na resposta aos Indicadores Ethos é voluntária e consiste numa ferramenta de gestão de uso interno por parte das empresas cuja principal finalidade é auxiliar os gestores na avaliação de suas práticas de responsabilidade social e no monitoramento do desempenho geral da empresa (INSTITUTO ETHOS, 2008).

Os dados cedidos referem-se às médias e grandes empresas instaladas no Brasil, uma vez que o Instituto Ethos possui os Indicadores Ethos-Sebrae de Responsabilidade Social e um banco de dados específico para micro e pequenas empresas. As empresas estão dispersas em várias regiões geográficas e fazem parte de setores variados, destacando-se: petróleo e gás, construção civil, metalurgia, informática e telecomunicações, transporte e armazenagem, química, saúde, energia e outros.

Para a formação de banco de dados do ano de 2008, o Instituto Ethos realizou uma campanha comunicação e motivação para preenchimento por parte de empresas associadas e não associadas ao Instituto. Mais de 1500 empresas cadastradas no mailing do Instituto Ethos foram convidadas a preencher os indicadores, via e-mail e correio. Além disso, para estimular o preenchimento, o Instituto realizou para empresas associadas, seis oficinas de capacitação para respondentes dirimindo dúvidas de interpretação. A coleta de dados ocorreu entre setembro de 2008 e maio de 2009 , e as empresas enviaram suas respostas por meio de um sistema on-line disponível em http://indicadores.ethos.org.br.

O preenchimento do questionário implicou num cadastramento da empresa com o uso de senha e a indicação de uma pessoa responsável. Além disso, o Instituto Ethos sugere que seja formado um grupo de trabalho com pessoas de várias áreas da empresa acompanhadas por um coordenador que centralizará e sistematizará as informações. Só foram aceitos pelo sistema, 
para a formação do banco de dados, os questionários integralmente preenchidos, sendo que apenas as questões quantitativas não são obrigatórias.

Apesar da boa quantidade de casos - 673 empresas pesquisadas - havia problema de falta de dados em algumas variáveis devido às instruções para preenchimento dos Indicadores Ethos 2008. O questionário prevê que as questões binárias qualificam a resposta escolhida no indicador de profundidade e quando estes são respondidos utilizando-se das opções "Não vemos a aplicação disso em nossa empresa" ou "Não havíamos tratado antes desse assunto", as questões binárias são automaticamente consideradas como não aplicáveis. A amostra de empresas com informações nesta situação foi reduzida pela retirada automática e completa de casos cujos dados apresentassem mais de dois valores nulos, os quais foram processados como "missing value", pelo software utilizado. Portanto, houve a exclusão de empresas com dados faltantes.

Para essa análise foram consideradas 331 empresas, de médio e grande porte, instaladas no Brasil, pertencentes a diferentes setores, as quais possuíam dados completos. A redução percentual do número de empresas é equivalente ao obtido por Giovaninni (2008) em estudo envolvendo correlação com o uso de banco de dados secundário.

Observa-se que a restrição no uso de casos com dados completos possibilitou circunscrever a análise àquelas empresas que já possuem envolvimento com a gestão socioambiental. Isto, porque, somente as empresas que se declaravam, nas questões de profundidade, minimamente comprometidas com o tema tinham acesso às questões binárias dispostas no questionário. Desta forma, pode-se dizer que o uso de empresas com dados completos estratificou qualitativamente os casos em análise.

Assim, a amostra pode ser caracterizada como não probabilística por conveniência, uma vez que não depende da probabilidade, mas das características da pesquisa (SAMPIERI et al, 2006). Apesar de possíveis desvantagens em relação à distorção nos resultados do estudo, esse tipo de amostra atende satisfatoriamente o objetivo da pesquisa, economiza tempo e recursos e, provavelmente, possibilitou o acesso a mais sujeitos. Portanto, tal característica pode permitir "[...] a obtenção de ricas informações para serem exploradas pela questão da pesquisa.” (SAUNDERS et al, 2007, p. 226). 
Destaca-se ainda, a partir de argumentos apresentados por Cooper e Schindler (2003, p. 163), que a amostragem aleatória simples é impraticável para este estudo tendo em vista que não está disponível uma listagem com o número total de empresas instaladas no Brasil envolvidas com a gestão socioambientalmente responsável.

\subsection{Modelo Teórico Conceitual da Pesquisa}

A partir do arcabouço teórico, admitiu-se que a sustentabilidade das empresas e da sociedade devem caminhar em conjunto, conforme detalhado na seção que descreve os pressupostos conceituais (item 1.5). Portanto, as empresas para serem atestadas como sustentáveis, devem contribuir para a manutenção da vida no planeta e assimilar a lógica de organização da natureza em suas atividades.

Assim, as diferentes ferramentas de gestão para a sustentabilidade das empresas precisam fomentar um modelo organizacional compatível com as propriedades de organização dos sistemas vivos. O modelo conceitual dessa tese propõe que a mudança na gestão implique numa transformação dos padrões de relações, incluindo características presentes nos ecossistemas. A perspectiva apresentada por Capra (1997, 2002, 2006) e avalizada por diversos estudiosos (COVEY, 1989; LASZLO, 2001; BOEIRA, 2002; ODUM; BARRETT, 2008; MÜELLER, 2007; SACHS, 2007; HAWKEN et al, 2000) sobre os fundamentos de organização dos ecossistemas, denominados de princípios ecológicos, foi utilizada como modelagem para identificar a existência de alinhamento da gestão das empresas com a sustentabilidade do planeta.

Para analisar a proposição, foi elaborado o modelo teórico de pesquisa, definido por Sampieri, et al (2006, p. 154) como um "[...] plano ou estratégia concebido para obter a informação que se deseja." Nesta tese, a representação desenvolvida busca analisar as relações entre variáveis pretensamente relacionadas.

O modelo proposto, que pode ser caracterizado como explicativo, implica na existência de correlação entre as ferramentas de gestão para a sustentabilidade e os princípios ecológicos (Figura 8). Para fins de estudo, definiu-se o sentido da causalidade das características 
mensuradas pela pesquisa, sem conotação de "causa-efeito", definindo-se variáveis preditoras e variáveis resposta.

Uma variável, para fins deste estudo, pode ser considerada uma "[...] propriedade de uma variação que pode ser medida ou observada.” (SAMPIERI et al, 2006, p. 121). Destaca-se que a escolha das variáveis foi condicionada não só pelos interesses da pesquisa em si, mas também pela disponibilidade de informações.

Mais informações sobre a composição das variáveis de estudo estão disponibilizadas no item 3.41 - A definição do agrupamento das variáveis. 


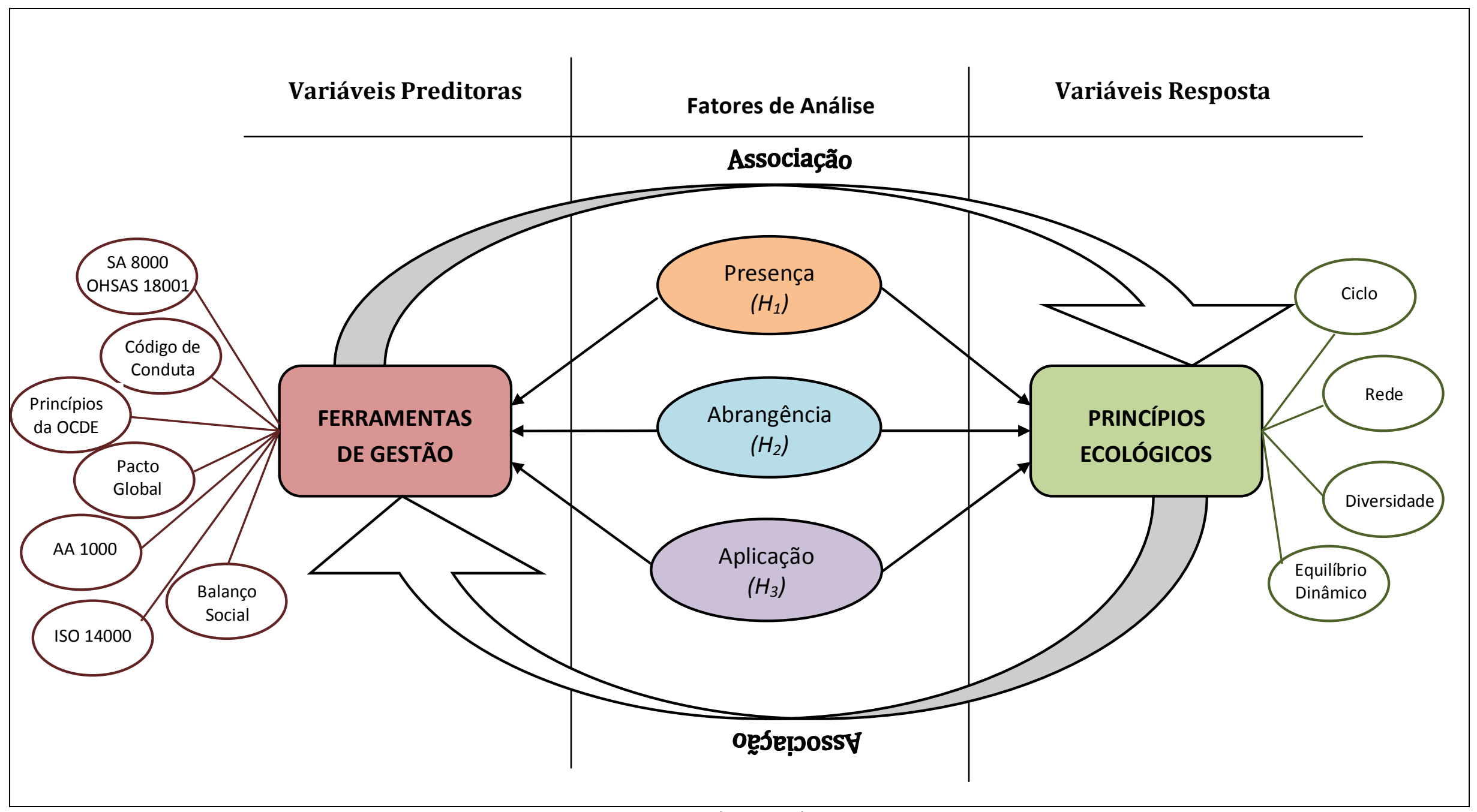

Figura 8 - Modelo teórico genérico da pesquisa 


\subsection{Instrumento de Pesquisa}

O questionário ${ }^{4}$ de indicadores desenvolvido pelo Instituto Ethos com a colaboração de parceiros é o instrumento utilizado neste estudo, tendo em vista a coleção de dados, referente ao ano de 2008, disponibilizada por esse mesmo Instituto na execução desta pesquisa ${ }^{5}$. Idealizado no ano 2000, o instrumento é revisado e aprimorado periodicamente para contemplar novas demandas da sociedade sobre as organizações. Pode ser caracterizado como auto-preenchível e estruturado com perguntas fechadas não disfarçadas. A versão 2008 se adapta à necessidade deste estudo de vincular conceitos abstratos com indicadores empíricos mediante classificação e quantificação.

O instrumento é organizado em sete temas - Valores, Transparência e Governança; Meio Ambiente; Público Interno; Fornecedores; Consumidores e Clientes; Comunidade e Governo e Sociedade - divididos em conjuntos de indicadores num total de 505 questões fechadas, sendo:

a) 40 questões em profundidade que permite avaliar o estágio atual de gestão da empresa em relação a determinada prática, a partir de quatro quadros contíguos;

b) 301 questões binárias, que qualificam a resposta escolhida no indicador de profundidade e;

c) 164 questões quantitativas para avaliar o desempenho da empresa segundo séries anuais.

As perguntas podem ser classificadas, conforme apresentado por Cooper e Schindler (2003, p. 181), em três níveis de medição: nominal, ordinal e de razão.

\subsubsection{A Definição do Agrupamento das Variáveis}

De um total de 505 questões presentes no questionário de Indicadores Ethos, foram utilizadas neste estudo 57 delas. As questões foram agrupadas em variáveis preditoras e variáveis resposta, para atender aos objetivos da pesquisa. Portanto, foi realizado um rearranjo das questões apresentadas no questionário dos Indicadores Ethos em novas categorias de análise.

\footnotetext{
${ }^{4} \mathrm{O}$ questionário de Indicadores Ethos 2008 está disponibilizado na internet no endereço: http://www.ethos.org.br/_Uniethos/documents/INDICADORESETHOS2008-PORTUGUES.pdf

${ }^{5}$ Para mais informações ver o item 3.2 - Definição do Universo e da Amostra.
} 


\subsubsection{Variáveis Preditoras}

Denominou-se de variáveis preditoras as ferramentas de gestão para a sustentabilidade, disposta no Quadro 10. Foram consideradas as ferramentas discriminadas no questionário dos Indicadores Ethos, num total de sete variáveis, sendo elas:

a) Código de Conduta;

b) Diretrizes da Organização para Cooperação e Desenvolvimento Econômico (OCDE);

c) Pacto Global;

d) AA 1000;

e) ISO 14001;

f) SA $8000 /$ OHSAS $18001 / \mathrm{BS} 8800 ; \mathrm{e}$

g) Balanço Social

Quadro 10 - Variáveis preditoras consideradas no estudo

\begin{tabular}{|c|c|c|c|c|}
\hline $\begin{array}{l}\text { CÓDIGO DA } \\
\text { VARIÁVEL }\end{array}$ & $\begin{array}{l}\text { NOME DA } \\
\text { VARIÁVEL }\end{array}$ & QUESTÃO & $\begin{array}{c}\mathbf{N}^{\circ} \text { DA } \\
\text { QUESTÃO } \\
\text { (a) }\end{array}$ & MEDIÇÃO \\
\hline PGLOBAL & Pacto Global & $\begin{array}{l}\text { Orienta suas operações em } \\
\text { concordância com os } \\
\text { Princípios do Pacto Global }\end{array}$ & 3.8 & NOMINAL \\
\hline OCDE & $\begin{array}{l}\text { Diretrizes da } \\
\text { Organização para } \\
\text { Cooperação e } \\
\text { Desenvolvimento } \\
\text { Econômico }\end{array}$ & $\begin{array}{c}\text { Orienta suas operações em } \\
\text { concordância com as diretrizes } \\
\text { para empresas multinacionais } \\
\text { da OCDE }\end{array}$ & 3.7 & NOMINAL \\
\hline CONDUTA & $\begin{array}{l}\text { Código da } \\
\text { Conduta }\end{array}$ & Possui um código de conduta & $\begin{array}{l}\text { Indicador } 01 \\
\text { (estágio } 2 \text { a } 4)\end{array}$ & ORDINAL \\
\hline BSOCIAL & Balanço Social & $\begin{array}{c}\text { Elabora anualmente um } \\
\text { balanço social que aborda } \\
\text { aspectos sociais, ambientais e } \\
\text { econômicos }\end{array}$ & $\begin{array}{l}\text { Indicador } 06 \\
\text { (estágio } 2 \text { a 4) }\end{array}$ & ORDINAL \\
\hline SA-OHSAS & $\begin{array}{c}\text { SA } 8000 / \text { BS } \\
8800 / \text { OHSAS } \\
18001\end{array}$ & $\begin{array}{l}\text { Foi certificada pela norma SA } \\
8000 \text {, pela BS } 8800 \text {, pela } \\
\text { OHSAS } 18001 \text { ou por norma } \\
\text { equivalente }\end{array}$ & 16.1 & NOMINAL \\
\hline AA1000 & AA 1000 & Aplica a norma AA 1000 & 5.7 & NOMINAL \\
\hline ISO14000 & ISO 14000 & $\begin{array}{c}\text { Possui certificação ambiental } \\
\text { ISO } 14001\end{array}$ & 22.7 & NOMINAL \\
\hline
\end{tabular}

(a) Número da questão refere ao algarismo da mesma no questionário dos Indicadores Ethos 2008.

Tendo em vista que algumas das questões selecionadas entre as variáveis preditoras possuem dados ordinais, em escala de profundidade, foi necessário realizar nova classificação destas respostas para que pudessem ser analisadas a partir de dados nominais com medidas binárias, possibilitando um mesmo padrão de informação. 
Portanto, a grandeza utilizada para mensuração refere-se à presença, ou não, dessas ferramentas na empresas, com nível de mediação nominal.

\subsubsection{Variáveis Resposta}

As variáveis resposta, isto é, características monitoradas pela pesquisa que podem ser afetadas pela manipulação das variáveis preditoras, foram definidas a partir dos princípios ecológicos descritos por Capra (1997, 2002, 2006). Esses princípios alteram-se entre as obras. Desta forma, optou-se por considerar os princípios ecológicos que, na sua essência conceitual, estão presente nas três obras, mesmo que discriminados nelas com diferentes denominações, sendo eles:

a) Rede: é definida por Capra (2002 e 2006) como as relações e as interdependências existentes entre os membros de uma comunidade ecológica, partilhando recursos e transpondo limites.

b) Ciclo: é conceituado por Capra $(1997,2002,2006)$ como fluxo de matéria e energia circulando continuamente entre os diferentes indivíduos.

c) Diversidade: na definição de Capra (1997, 2002, 2006) está vinculada à estrutura e à complexidade das conexões da rede, proporcionando maior flexibilidade.

d) Equilíbrio Dinâmico: para Capra (2002 e 2006) refere-se à existência de múltiplos elos e anéis de realimentação, em permanente flutuação, que tendem a levar o sistema de volta ao equilíbrio

A partir das definições propostas por Capra e para identificar a presença dos princípios ecológicos nas empresas foram redefinidos nesta tese novos agrupamentos das questões presentes no questionário de Indicadores do Instituto Ethos. Tal esforço teve como objetivo aproximar as definições propostas pelo ramo da ecologia à realidade organizacional, para analisar a existência de um padrão de organização da empresa denominados de princípios ecológicos. Nessa reorganização, obedeceu-se os critérios de objetividade e de orientação para a testabilidade apresentados por Kerlinger (1980, p.46-50).

As variáveis foram arranjadas em três níveis fundamentais. No primeiro nível, são apresentadas quatro dimensões (macrovariáveis) definidas com princípios ecológicos. No segundo nível, encontram-se as variáveis de cada dimensão do modelo. Destaca-se que a definição das variáveis foi embasada em obras de autores que estudam a gestão 
socioambiental e a sustentabilidade nas organizações. Já no terceiro nível são apresentadas as questões presentes no questionário de Indicadores Ethos que possibilitam a mensuração das variáveis. Operacionalmente as variáveis resposta foram definidas, conforme segue nas descrições abaixo.

\section{Macrovariável Rede}

Nesta tese, a expressão é entendida como a existência de coordenação e arranjo de empresas de uma cadeia produtiva em aspectos socioambientais, decorrentes da racionalidade estratégica, transpondo limites organizacionais e almejando identidade de atuação socioambiental, conforme apresentado no Quadro 11.

No que se refere à Macrovariável Rede, Savitz (2007) aponta que os relacionamentos mais cruciais e também alguns dos mais difíceis de gerenciar referem-se àqueles vinculados a outras empresas da cadeia de valor, uma vez que, tradicionalmente, concentram-se em lucro, prazos e multas contidas nos contratos.

Quadro 11 - Macrovariável rede e as variáveis de análise Macro-variável: REDE

\footnotetext{
Variável: VR1- Existência de programa de responsabilidade socioambiental para a cadeia produtiva Justificativa:

Quanto mais as questões socioambientais, enquanto estratégia de gestão, estão presentes nas empresas, mais diferenciada é a natureza do relacionamento com os fornecedores. Na opinião de Savitz (2007), o lucro, a melhoria da eficiência e a garantia de qualidade deixam de ser as únicas considerações no mapeamento das cláusulas do contrato que incluem temas como segurança no trabalho, condições de trabalho, direitos humanos e mão-de-obra infantil.
}

Alguns autores que abordam o tema: Elkington (2001); Barbieri (2007); Savitz (2007); Nascimento et al (2008); Pinheiro (2009).

\section{Variável: VR2- Critérios socioambientais para compras}

\section{Justificativa:}

Nascimento et al (2008) afirmam que, independentemente dos clientes valorizarem ou não os atributos ambientais e sociais vinculados a um produto, o responsável da área de compras deve analisar os impactos na sociedade dos insumos adquiridos para reforçar a estratégia de gestão adotada. Os autores afirmam ainda que "[...] comprar de alguém que não possui boas práticas socioambientais podem afetar a imagem de quem está comprando.” (p. 188).

Alguns autores que abordam o tema: Elkington (2001); Barbieri (2007); Savitz (2007); Nascimento et al (2008). Variável: VR3- Monitoramento de posturas socioambientais de fornecedores

\section{Justificativa:}

Savitz (2007) afirma que muitas empresas envolvidas em questões socioambientais relutam em acompanhar o engajamento dos fornecedores com o tema por saberem que não serão capazes de garantir sua observância. Visitas de inspeção e critérios de avaliação podem tornar-se importantes práticas para garantir a consistência socioambiental da rede.

Alguns autores que abordam o tema: Savitz (2007); GRI (2008); Aligleri et al (2009). 
Dessa forma, foram definidas como variáveis de análise para o entendimento de redes de empresas mais sustentáveis: a existência de programa de responsabilidade socioambiental para a cadeia produtiva, a adoção de critérios socioambientais para compras e o monitoramento de fornecedores. Segue, no Quadro 12, as questões advindas do questionário dos Indicadores Ethos utilizadas na composição da macrovariável rede e suas variáveis.

Quadro 12 - Variáveis resposta pertencentes a macrovariável rede

\begin{tabular}{|c|c|c|c|c|}
\hline $\begin{array}{l}\text { Código e Nome } \\
\text { da Variável }\end{array}$ & $\begin{array}{c}\text { Código da } \\
\text { Questão }\end{array}$ & Questão & $\begin{array}{c}\mathbf{N}^{0} \text { da } \\
\text { Questão (a) }\end{array}$ & Medição \\
\hline \multirow{3}{*}{$\begin{array}{l}\text { VR1 } \\
\text { Existência de } \\
\text { programa de } \\
\text { responsabilidade } \\
\text { socioambiental } \\
\text { para a cadeia de } \\
\text { fornecedores } \\
\end{array}$} & VR1-1 & $\begin{array}{c}\text { Possui política explícita ou programa específico de } \\
\text { responsabilidade social para a cadeia de } \\
\text { fornecedores. }\end{array}$ & 25.3 & Nominal \\
\hline & VR1-2 & $\begin{array}{c}\text { Discute questões relacionadas à responsabilidade } \\
\text { social com seus fornecedores, visando o treinamento } \\
\text { e adequação deles aos seus critérios. }\end{array}$ & 25.5 & Nominal \\
\hline & VR1-3 & $\begin{array}{l}\text { Possui política de compras que privilegia } \\
\text { fornecedores com certificação socioambiental. }\end{array}$ & 28.5 & Nominal \\
\hline \multirow{6}{*}{$\begin{array}{c}\text { VR2 } \\
\text { Critérios } \\
\text { socioambientais } \\
\text { para compras }\end{array}$} & VR2-1 & $\begin{array}{l}\text { Contrata fornecedores que comprovadamente } \\
\text { tenham boa conduta ambiental. }\end{array}$ & 22.6 & Nominal \\
\hline & VR2-2 & $\begin{array}{l}\text { Prioriza fornecedores engajados na busca da } \\
\text { sustentabilidade das florestas. }\end{array}$ & 23.3 & Nominal \\
\hline & VR2-3 & $\begin{array}{l}\text { Conhece a origem das matérias-primas, insumos e } \\
\text { produtos utilizados nas suas operações diárias e tem } \\
\text { a garantia de que nessa origem os direitos humanos } \\
\text { e o meio ambiente são respeitados. }\end{array}$ & 25.8 & Nominal \\
\hline & VR2-4 & $\begin{array}{c}\text { Adota critérios de compra que consideram a garantia } \\
\text { de origem, para evitar a aquisição de produtos } \\
\text { piratas, falsificados ou frutos de roubo de carga. }\end{array}$ & 25.9 & Nominal \\
\hline & VR2-5 & $\begin{array}{c}\text { Verifica a Lista Suja de Trabalho Forçado do } \\
\text { Ministério do Trabalho antes de comprar ou } \\
\text { contratar fornecedor. }\end{array}$ & 27.2 & Nominal \\
\hline & VR2-6 & $\begin{array}{l}\text { Busca o tratamento justo aos fornecedores, } \\
\text { privilegiando o pequeno fornecedor com } \\
\text { remuneração justa em dia, programas de } \\
\text { qualificação e de transferência de tecnologia. }\end{array}$ & 28.3 & Nominal \\
\hline \multirow{4}{*}{$\begin{array}{c}\text { VR3 } \\
\text { Monitoramento } \\
\text { de posturas } \\
\text { socioambientais } \\
\text { de fornecedores }\end{array}$} & VR3-1 & $\begin{array}{l}\text { Produz relatório periódico com evidências de que } \\
\text { questões relacionadas a responsabilidade social } \\
\text { estão sendo cumpridas e implementadas na sua } \\
\text { cadeia produtiva. } \\
\end{array}$ & 25.4 & Nominal \\
\hline & VR3-2 & $\begin{array}{l}\text { Estabelece prazo formal para que os fornecedores } \\
\text { entrem em conformidade com seus critérios de } \\
\text { responsabilidade social. }\end{array}$ & 25.6 & Nominal \\
\hline & VR3-3 & $\begin{array}{l}\text { Realiza visitas de inspeção das práticas de } \\
\text { responsabilidade social de seus fornecedores. }\end{array}$ & 25.7 & Nominal \\
\hline & VR3-4 & $\begin{array}{l}\text { Possui critérios socioambientais de seleção e } \\
\text { avaliação de fornecedores adotando a coleta de } \\
\text { evidências de que cumprem as exigências. }\end{array}$ & $\begin{array}{l}\text { Indicador 25 } \\
\text { (estágio 4) }\end{array}$ & Ordinária \\
\hline
\end{tabular}

(a) Número da questão refere ao algarismo da mesma no questionário dos Indicadores Ethos 2008.

\section{Macrovariável Ciclo}

Ciclo é conceituado neste trabalho como práticas de gerenciamento sistêmico dos danos e impactos potenciais do ciclo da matéria de produtos e serviços, gerados pela empresa, sobre o ambiente. 
Em relação a esta Macrovariável, busca-se analisar se a empresa replanejou e reestruturou o seu sistema produtivo inserindo uma nova lógica de relacionamento com o meio ambiente e, portanto, minimizando o impacto gerado, conforme disposto no Quadro 13. Práticas de gestão de resíduos de produção, análise dos fluxos de materiais e design ambiental de produtos são atividades gerenciais importantes para reduzir os danos potenciais da organização.

Quadro 13 - Macrovariável ciclo e as variáveis de análise Macro-variável: CICLO

\section{Variável: VC1 - Redução do impacto ambiental nos processos internos}

\section{Justificativa:}

Melhorar o desempenho nos processos internos, na forma de novos compromissos e práticas de gestão, leva a uma redução de desperdícios e perdas. Portanto, contribui para o uso mais eficiente dos recursos ambientais.

Alguns autores que abordam o tema: Elkington (2001); Barbieri (2007); Savitz (2007).

\section{Variável: VC2 - Concepção ecológica do produto e destinação pós-consumo}

\section{Justificativa:}

Numa gestão mais sustentável é importante assegurar que questões ambientais sejam levadas em conta no desenvolvimento de novas tecnologias. Portanto, a coleta e reciclagem pós-consumo, a reciclagem final dos produtos e o design de produtos que considera os impactos ambientais, reduzindo ou eliminando o impacto na fonte, tornam-se dimensões relevantes numa gestão mais cíclica de processos.

Alguns autores que abordam o tema: Bello (1998); Elkington (2001); Savitz (2007).

\section{Variável: VC3- Ecoeficiência}

\section{Justificativa:}

Reduzir o uso de recursos naturais demonstra que a empresa está consciente dos impactos causados, reforçando uma postura proativa de relacionamento com o ambiente.

Alguns autores que abordam o tema: Barbieri (2007); Nascimento et al (2008); Aligleri et al (2009).

Segue, no quadro 14 as questões advindas do questionário dos Indicadores Ethos utilizadas na composição da macrovariável ciclo e suas variáveis. 


\begin{tabular}{|c|c|c|c|c|}
\hline $\begin{array}{l}\text { Código e Nome } \\
\text { da Variável }\end{array}$ & $\begin{array}{l}\text { Código da } \\
\text { Questão }\end{array}$ & Questão & $\begin{array}{c}\mathbf{N}^{\mathbf{o}} \text { da } \\
\text { Questão (a) }\end{array}$ & Medição \\
\hline \multirow{4}{*}{$\begin{array}{c}\text { VC1 } \\
\text { Redução do } \\
\text { impacto } \\
\text { ambiental nos } \\
\text { processos internos }\end{array}$} & VC1-1 & $\begin{array}{l}\text { Assume compromisso e responsabilidade com os } \\
\text { impactos ambientais resultantes da atividade da } \\
\text { empresa priorizando políticas preventivas. }\end{array}$ & $\begin{array}{l}\text { Indicador } 20 \\
\text { (estágio } 2 \text { a } 3 \text { ) }\end{array}$ & Ordinária \\
\hline & VC1-2 & $\begin{array}{l}\text { Gerencia os impactos dos produtos e processos } \\
\text { sobre o meio ambiente a partir de um sistema de } \\
\text { gestão padronizado e formalizado. }\end{array}$ & $\begin{array}{l}\text { Indicador } 22 \\
\text { (estágio } 2 \text { e } 3 \text { ) }\end{array}$ & Ordinária \\
\hline & VC1-3 & $\begin{array}{c}\text { Possui sistema para minimizar entradas e saídas de } \\
\text { materiais adotando estratégias de reutilização e } \\
\text { compensação ambiental envolvendo o sistema } \\
\text { produtivo. }\end{array}$ & $\begin{array}{l}\text { Indicador } 24 \\
\text { (estágio 4) }\end{array}$ & Ordinária \\
\hline & VC1-4 & $\begin{array}{c}\text { Gerencia os danos potenciais dos produtos e } \\
\text { serviços adotando medidas preventivas e corretivas } \\
\text { quando detectados riscos de falhas. }\end{array}$ & $\begin{array}{l}\text { Indicador } 31 \\
\text { (estágio } 2 \text { a } 3 \text { ) }\end{array}$ & Ordinária \\
\hline \multirow{3}{*}{$\begin{array}{c}\text { VC2 } \\
\text { Concepção } \\
\text { ecológica do } \\
\text { produto e } \\
\text { destinação pós- } \\
\text { consumo }\end{array}$} & VC2-1 & $\begin{array}{l}\text { Assume compromisso e responsabilidade com os } \\
\text { impactos ambientais ao desenvolver novos } \\
\text { negócios, levando em conta, desde a concepção, os } \\
\text { princípios da sustentabilidade }\end{array}$ & $\begin{array}{l}\text { Indicador } 20 \\
\text { (estágio 4) }\end{array}$ & Ordinária \\
\hline & VC2-2 & $\begin{array}{l}\text { Produz estudos de impacto em toda cadeia } \\
\text { produtiva visando a melhoria de seus processos e } \\
\text { participa da destinação final dos produtos e } \\
\text { processo de pós-consumo. }\end{array}$ & $\begin{array}{l}\text { Indicador } 22 \\
\text { (estágio 4) }\end{array}$ & Ordinária \\
\hline & VC2-3 & $\begin{array}{l}\text { Gerencia os danos potenciais dos produtos e } \\
\text { serviços considerando o desenvolvimento } \\
\text { sustentável e a ética como dimensões importantes } \\
\text { na concepção, reformulação, fabricação e venda. }\end{array}$ & $\begin{array}{l}\text { Indicador } 31 \\
\text { (estágio 4) }\end{array}$ & Ordinária \\
\hline \multirow{4}{*}{$\begin{array}{l}\mathrm{VC3} \\
\text { Ecoeficiência }\end{array}$} & VC3-1 & $\begin{array}{l}\text { Possui iniciativas para uso de fontes de energia } \\
\text { renovável. }\end{array}$ & 24.1 & Nominal \\
\hline & VC3-2 & $\begin{array}{l}\text { Possui sistema de monitoramento com metas } \\
\text { específicas para aumento da eficiência energética. }\end{array}$ & 24.3 & Nominal \\
\hline & VC3-3 & $\begin{array}{l}\text { Possui sistema de monitoramento com metas } \\
\text { específicas para redução do consumo de água. }\end{array}$ & 24.4 & Nominal \\
\hline & VC3-4 & $\begin{array}{l}\text { Possui sistema de monitoramento com metas } \\
\text { específicas para geração de resíduos sólidos. }\end{array}$ & 24.5 & Nominal \\
\hline
\end{tabular}

(1) Número da questão refere ao algarismo da mesma no questionário dos Indicadores Ethos 2008.

\section{Macrovariável Diversidade}

A Diversidade é caracterizada neste trabalho como a existência de mecanismos para interação, comunicação e relacionamento com diferentes públicos, abrangendo a pluralidade no ambiente interno e proporcionando associações e parcerias junto aos stakeholders.

Portanto, está relacionada à variedade e à qualidade das interações com diferentes públicos. Integrar stakeholders no processo de gestão, por meio de cooperação, participação, diálogo e transparência pode ser considerado uma forma efetiva para alinhar os interesses da sociedade aos interesses da empresa, conforme apresentado no Quadro 15. Foram definidas como variáveis de análise para esta Macrovariável: a pluralidade no quadro de colaboradores, o envolvimento com questões da comunidade e de interesse público, a inserção da comunidade na rede de negócios e o diálogo e comunicação com os públicos de relacionamento. 
Quadro 15 - Macrovariável diversidade e as variáveis de análise Macro-variável: DIVERSIDADE

Variável: VD1- Pluralidade e participação dos colaboradores na gestão

Justificativa:

A existência de menores aprendizes, negros, pessoas com deficiência e o tratamento com equidade de gênero possibilita identificar a diversidade no âmbito interno da empresa. Além disso, conforme descrito por Barbieri (2007, p. 53), um alto envolvimento dos colaboradores na gestão propicia maior comprometimento, promove novas competências e facilita a disseminação das práticas e políticas socioambientais.

Alguns autores que abordam o tema: Barbieri (2007); Elkington (2001); Nascimento et al (2008); Aligleri et al (2009).

Variável: VD2- Envolvimento com questões da comunidade e de interesse público

Justificativa:

Interação e atuação em conjunto com organizações não-governamentais e esferas públicas, conforme descrito por Barbieri (2007), ampliam o aprendizado compartilhado, geram soluções sistêmicas e o aperfeiçoamento das relações, contribuindo com o propósito de alcançar o desenvolvimento sustentável.

Alguns autores que abordam o tema: Barbieri (2007); Savitz (2007); Aligleri et al (2009).

Variável: VD3- Inserção da comunidade na rede de negócios

Justificativa:

Estimular a geração de capacidades locais, incluindo grupos da comunidade entre fornecedores ou empregando moradores da região onde a empresa está instalada, melhora a qualidade de vida da população local e contribui com o desenvolvimento econômico e social da mesma.

Alguns autores que abordam o tema: Mendonça (2007); Aligleri et al (2009).

Variável: VD4- Diálogo e comunicação com os públicos de relacionamento

Justificativa:

O diálogo e a comunicação são importantes atitudes para reconhecer a existência de elos de realimentação entre a empresa e diferentes agentes sociais. Ferramentas e políticas organizacionais que permitem conhecer a percepção dos stakeholders aumentam a quantidade e a qualidade das informações sobre o ambiente, possibilitam adaptação mais rápida e, possivelmente, amplia a efetividade de resposta.

Alguns autores que abordam o tema: Frooman (1999); Carrol e Buchholtz (2000); Ashley (2002); Zadek (2004); Savitz (2007); Almeida (2007).

Segue, no quadro 16, as questões advindas do questionário dos Indicadores Ethos utilizadas na composição da macrovariável diversidade e suas variáveis. 
Quadro 16 - Variáveis resposta pertencentes a macrovariável diversidade

\begin{tabular}{|c|c|c|c|c|}
\hline $\begin{array}{c}\text { Código e Nome } \\
\text { da Variável }\end{array}$ & $\begin{array}{c}\text { Código da } \\
\text { Questão }\end{array}$ & Questão & $\begin{array}{c}\mathbf{N}^{0} \text { da } \\
\text { Questão (a) }\end{array}$ & Medição \\
\hline \multirow{5}{*}{$\begin{array}{c}\text { VD1 } \\
\text { Pluralidade e } \\
\text { participação dos } \\
\text { colaboradores na } \\
\text { gestão }\end{array}$} & VD1-1 & $\begin{array}{l}\text { Possui políticas e mecanismos formais para ouvir, } \\
\text { avaliar e acompanhar posturas, preocupações e } \\
\text { críticas dos empregados. }\end{array}$ & 8.2 & Nominal \\
\hline & VD1-2 & $\begin{array}{l}\text { Possui programa de incentivo e reconhecimento das } \\
\text { sugestões dos empregados para melhoria dos } \\
\text { processos internos. }\end{array}$ & 8.3 & Nominal \\
\hline & VD1-3 & $\begin{array}{c}\text { Possui procedimentos específicos para melhorar a } \\
\text { qualificação e promover pessoas com deficiência } \\
\text { derivados da política de valorização da diversidade } \\
\text { e não discriminação. }\end{array}$ & 11.15 & Nominal \\
\hline & VD1-4 & $\begin{array}{l}\text { Possui procedimentos específicos para melhorar a } \\
\text { qualificação e o desenvolvimento na carreira de } \\
\text { empregados negros derivados da política de } \\
\text { promoção da equidade e não discriminação racial. }\end{array}$ & 12.2 & Nominal \\
\hline & VD1-5 & $\begin{array}{l}\text { Possui procedimentos específicos para melhorar a } \\
\text { qualificação das mulheres e promovê-las derivados } \\
\text { da política de promoção da equidade de gênero. }\end{array}$ & 13.2 & Nominal \\
\hline \multirow{5}{*}{$\begin{array}{l}\text { VD2 } \\
\text { Envolvimento } \\
\text { com questões da } \\
\text { comunidade e de } \\
\text { interesse público }\end{array}$} & VD2-1 & $\begin{array}{l}\text { Participa de comitês/conselhos locais ou regionais } \\
\text { para discutir a questão ambiental com o governo e a } \\
\text { comunidade. }\end{array}$ & 20.3 & Nominal \\
\hline & VD2-2 & $\begin{array}{l}\text { Contribui para a preservação da diversidade por } \\
\text { meio de políticas específicas e projetos de } \\
\text { conservação de áreas protegidas e/ou programas de } \\
\text { proteção a animais ameaçados. }\end{array}$ & 20.4 & Nominal \\
\hline & VD2-3 & $\begin{array}{c}\text { Gerencia os impactos da empresa na comunidade } \\
\text { de entorno através de uma política formal, } \\
\text { envolvendo a comunidade na resolução dos } \\
\text { problemas. }\end{array}$ & $\begin{array}{l}\text { Indicador } 32 \\
\text { (estágio } 1 \text { e } 3 \text { ) }\end{array}$ & Ordinária \\
\hline & VD2-4 & $\begin{array}{c}\text { Possui política de relacionamento com } \\
\text { organizações locais participando da elaboração de } \\
\text { implantação de projetos conjuntos. }\end{array}$ & $\begin{array}{l}\text { Indicador } 33 \\
\text { (estágio } 2 \text { a } 4 \text { ) }\end{array}$ & Ordinária \\
\hline & VD2-5 & $\begin{array}{l}\text { Possui políticas para liderança e influência social } \\
\text { tendo membros da alta administração envolvidos na } \\
\text { articulação de fortalecimento de propostas de } \\
\text { caráter socioambiental. }\end{array}$ & $\begin{array}{l}\text { Indicador } 39 \\
\text { (estágio } 2 \text { a } 4 \text { ) }\end{array}$ & Ordinária \\
\hline \multirow{4}{*}{$\begin{array}{l}\text { VD3 } \\
\text { Inserção da } \\
\text { comunidade na } \\
\text { rede de negócios }\end{array}$} & VD3-1 & $\begin{array}{l}\text { Inclui entre seus fornecedores indivíduos ou grupos } \\
\text { da comunidade, tais como cooperativas de } \\
\text { pequenos produtores ou de iniciativas solidárias, } \\
\text { associações de bairro e organizações com projetos } \\
\text { de renda para grupos usualmente excluídos. }\end{array}$ & 28.1 & Nominal \\
\hline & VD3-2 & $\begin{array}{l}\text { Estimula a formação de rede ou cooperativas de } \\
\text { pequenos fornecedores, ajudando-os a se adequar a } \\
\text { novos padrões de fornecimento. }\end{array}$ & 28.4 & Nominal \\
\hline & VD3-3 & $\begin{array}{l}\text { Possui programas para empregar o maior número } \\
\text { de moradores do local onde está inserida, dando- } \\
\text { lhes formação em cooperação com sindicatos, } \\
\text { ONGs ou autoridades públicas competentes. }\end{array}$ & 32.5 & Nominal \\
\hline & VD3-4 & $\begin{array}{l}\text { Possui prática de compras e investimentos para } \\
\text { aprimorar o desenvolvimento socioeconômico da } \\
\text { comunidade em que está presente. }\end{array}$ & 32.6 & Nominal \\
\hline \multirow{4}{*}{$\begin{array}{l}\text { VD4 } \\
\text { Diálogo e } \\
\text { comunicação com } \\
\text { os públicos de } \\
\text { relacionamento }\end{array}$} & VD4-1 & $\begin{array}{c}\text { Está aberta a críticas de grupos ou partes } \\
\text { interessadas sobre a natureza de seus processos, } \\
\text { produtos ou serviços. }\end{array}$ & 5.1 & Nominal \\
\hline & VD4-2 & $\begin{array}{c}\text { Busca o diálogo e o engajamento das partes } \\
\text { interessadas por meio de ferramentas e políticas } \\
\text { específicas, redefinindo políticas e processos de } \\
\text { gestão. }\end{array}$ & $\begin{array}{l}\text { Indicador } 05 \\
\text { (estágio } 2 \text { a } 4)\end{array}$ & Ordinária \\
\hline & VD4-3 & $\begin{array}{l}\text { Possui ouvidor de fornecedores ou função similar, } \\
\text { para assegurar uma relação de parceria com eles. }\end{array}$ & 28.7 & Nominal \\
\hline & VD4-4 & $\begin{array}{l}\text { Possui um ouvidor do consumidor ou função } \\
\text { similar. }\end{array}$ & 30.2 & Nominal \\
\hline
\end{tabular}

(1) Número da questão refere ao algarismo da mesma no questionário dos Indicadores Ethos 2008. 


\section{Macrovariável Equilíbrio Dinâmico}

O Equilíbrio Dinâmico, última macrovariável de resposta estudada, é definido nesta pesquisa como a existência de monitoramento de variáveis socioambientais na dinâmica de gestão servindo como laços de realimentação para o aprendizado e a adaptação da empresa, conforme apresentado no Quadro 17. Analisado pela constatação de presença de indicadores para a mensuração do desempenho socioambiental, bem como o aprimoramento da atuação, segundo séries anuais.

Desta forma, propõe-se identificar a existência de mecanismos de monitoramento, na forma de novos padrões de medida, para acompanhar o desempenho socioambiental. Busca, também, obter evidência de evolução dos resultados socioambientais obtidos. Tal perspectiva é reforçada por Elkington (2001) que destaca a necessidade de uma gama de indicadores e objetivos para melhorar o sistema de gerenciamento socioambiental, como também a importância da avaliação dos efeitos ambientais e sociais reais obtidos.

Quadro 17 - Macrovariável equilíbrio dinâmico e as variáveis de análise Macro-variável: EQUILÍBRIO DINÂMICO

Variável: VE1- Mecanismos de monitoramento das relações com diferentes públicos de relacionamento Justificativa:

Assumir de forma voluntária um mapeamento e monitoramento de questões socioambientais por meio de novos indicadores de gestão implica em maior complexidade devido a um maior número de elos e anéis de realimentação para o processo de decisão.

Alguns autores que abordam o tema: Elkington (2001); Borger (2004), Silva, (2006) Barbieri (2007); Savitz (2007); Nascimento et al (2008); Hourneaux (2010).

Variável: VE2- Avaliação do desempenho social

Justificativa:

O desempenho social mais elevado, ao longo do tempo, reforça a preocupação da empresa em manter um valor ótimo de resposta aos anseios e exigências advindos do meio.

Alguns autores que abordam o tema: Elkington (2001); Barbieri (2007); Savitz (2007); GRI (2008). Variável: VE3 - Avaliação do desempenho ambiental

Justificativa:

O uso mais eficiente de recursos ambientais indica um aprimoramento da gestão e, portanto, um desempenho mais otimizado encaminhando a empresa para uma atuação em harmonia com o meio ambiente.

Alguns autores que abordam o tema: Elkington (2001); Barbieri (2007); Savitz (2007); GRI (2008).

Segue, no quadro 18, as questões advindas do questionário dos Indicadores Ethos utilizadas na composição da macrovariável Equilíbrio Dinâmico e suas variáveis. 
Quadro 18 - Variáveis resposta pertencentes a macrovariável equilíbrio dinâmico

\begin{tabular}{|c|c|c|c|c|}
\hline $\begin{array}{l}\text { Código e Nome } \\
\text { da Variável }\end{array}$ & $\begin{array}{l}\text { Código da } \\
\text { Questão }\end{array}$ & Questão & $\begin{array}{c}\mathbf{N}^{\mathbf{0}} \text { da } \\
\text { Questão (a) }\end{array}$ & Medição \\
\hline \multirow{3}{*}{$\begin{array}{c}\text { VE1 } \\
\text { Mecanismos de } \\
\text { avaliação e } \\
\text { monitoramento } \\
\text { das relações com } \\
\text { diferentes } \\
\text { públicos de } \\
\text { relacionamento }\end{array}$} & VE1-1 & $\begin{array}{l}\text { Nos processos e ferramentas de gestão de pessoas, a } \\
\text { empresa insere quesitos para monitorar a } \\
\text { diversidade de seu quadro e possíveis desigualdades } \\
\text { em relação aos segmentos em desvantagem. }\end{array}$ & 11.1 & Nominal \\
\hline & VE1-2 & $\begin{array}{l}\text { Dispõe de processos para mapeamento e análise } \\
\text { sistêmica para a melhoria da qualidade ambiental. }\end{array}$ & 20.6 & Nominal \\
\hline & VE1-3 & $\begin{array}{l}\text { Possui indicadores para monitorar os impactos } \\
\text { causados por suas atividades na comunidade de } \\
\text { entorno. }\end{array}$ & 32.8 & Nominal \\
\hline \multirow{7}{*}{$\begin{array}{l}\text { VE2 } \\
\text { Avaliação do } \\
\text { Desempenho } \\
\text { social }\end{array}$} & VE2-1 & Total de menores aprendizes na empresa. & 9.5 & Razão \\
\hline & VE2-2 & Percentual de pessoas com deficiência na empresa. & 11.22 & Razão \\
\hline & VE2-3 & Percentual de pessoas com idade superior a 45 anos. & 11.28 & Razão \\
\hline & VE2-4 & $\begin{array}{l}\text { Divisão do menor salário da empresa pelo salário } \\
\text { mínimo vigente. }\end{array}$ & 15.10 & Razão \\
\hline & VE2-5 & Média de acidentes de trabalho por empregado/ano. & 16.14 & Razão \\
\hline & VE2-6 & $\begin{array}{l}\text { Percentual de reclamações em relação ao total de } \\
\text { ligações atendidas pelo SAC. }\end{array}$ & 30.18 & Razão \\
\hline & VE2-7 & $\begin{array}{l}\text { Percentual de empregados que realizam trabalho } \\
\text { voluntário na comunidade. }\end{array}$ & 35.10 & Razão \\
\hline \multirow{5}{*}{$\begin{array}{l}\text { VE3 } \\
\text { Avaliação do } \\
\text { Desempenho } \\
\text { ambiental }\end{array}$} & VE3-1 & $\begin{array}{l}\text { Quantidade média de incidentes, autuações e/ou } \\
\text { multas por violação das normas de proteção } \\
\text { ambiental. }\end{array}$ & 22.8 & Razão \\
\hline & VE3-2 & Consumo anual de energia (em KWh). & 24.9 & Razão \\
\hline & VE3-3 & Consumo anual de água (em m3). & 24.10 & Razão \\
\hline & VE3-4 & $\begin{array}{l}\text { Volume médio anual de gases de efeito estufa } \\
\text { emitidos na atmosfera (ton). }\end{array}$ & 24.11 & Razão \\
\hline & VE3-5 & $\begin{array}{l}\text { Quantidade anual (em ton) de resíduos sólidos } \\
\text { gerados (lixo, dejetos, entulhos). }\end{array}$ & 24.12 & Razão \\
\hline
\end{tabular}

(a) Número da questão refere ao algarismo da mesma no questionário dos Indicadores Ethos 2008.

Para a validade de conteúdo das variáveis e dos constructos utilizados nesta pesquisa, além da conceituação de autores desenvolvida em trabalhos anteriores, foram padronizadas as medidas operacionais para os conceitos estudados, bem como realizada a análise de consistência interna dos itens múltiplos associados.

Tendo em vista que também entre as variáveis resposta há três escalas de medição, envolvendo dados ordinais, nominais e de razão, foi necessário realizar nova requalificação destas respostas. As variáveis que envolviam, simultaneamente, dados ordinais e nominais foram analisadas a partir de dados nominais com medidas binárias, possibilitando um mesmo padrão de informação. A mensuração refere-se, portanto, à presença ou não dessas práticas na empresas.

Já a requalificação das questões quantitativas com dados de razão presentes nas variáveis "Avaliação do Desempenho Ambiental" e "Avaliação do Desempenho Social”, que integram a macrovariável "Equilíbrio Dinâmico", foi realizada a partir da variação das respostas dadas pelas empresas entre os anos de 2007 e 2008 e envolveu elevado grau de acuidade da 
pesquisadora. Os dados foram reclassificados em "pior desempenho", quando houve decréscimo na situação; "manutenção do desempenho", quando a empresa reportou o mesmo valor do ano anterior; e "melhor desempenho", quando a empresa melhorou sua performance na série anual. Destaca-se ainda que, como as perguntas quantitativas presentes no questionário são consideradas opcionais, mesmo as não respostas (missing data) foram apreciadas numa categoria de análise. A pesquisadora procedeu desta forma, pois tal fato indica que as empresas não monitoram esse indicador, o que se torna uma informação importante para os objetivos propostos nesta pesquisa.

É importante relatar ainda que a formação de cada uma das dimensões das variáveis resposta foi realizada em três etapas. A primeira baseada somente na leitura e interpretação das questões com base no levantamento bibliográfico e elementos estabelecidos a priori pela pesquisadora.

A segunda apreciação foi baseada na amostra a partir de uma análise de aglomerados, ou clusters, obtendo um direcionamento amostral para o agrupamento de itens. A distância entre os itens foi calculada utilizando-se de correlações policóricas inter-itens e de cada item, que consiste em uma estimativa de máxima verossimilhança para a correlação entre variáveis ordinais. Objetivou-se com tal análise verificar se os construtos propostos apresentavam consistência interna, sendo que o nível mínimo utilizado para a inclusão de um item num construto foi de 0.3 (SOARES, 2005).

A terceira e última análise realizada para a formação das variáveis foi baseada nas duas etapas anteriores implicando rearranjos e em novos agrupamentos. Seguem as Tabelas 1 a 4 de correlações policóricas dos constructos finais das variáveis resposta envolvidas no estudo. São apresentadas em destaque as questões que agrupadas compõem as variáveis. 
Tabela 1- Matriz de correlações policóricas inter-itens e de cada item com o escore total das variáveis que compõem a macrovariável rede

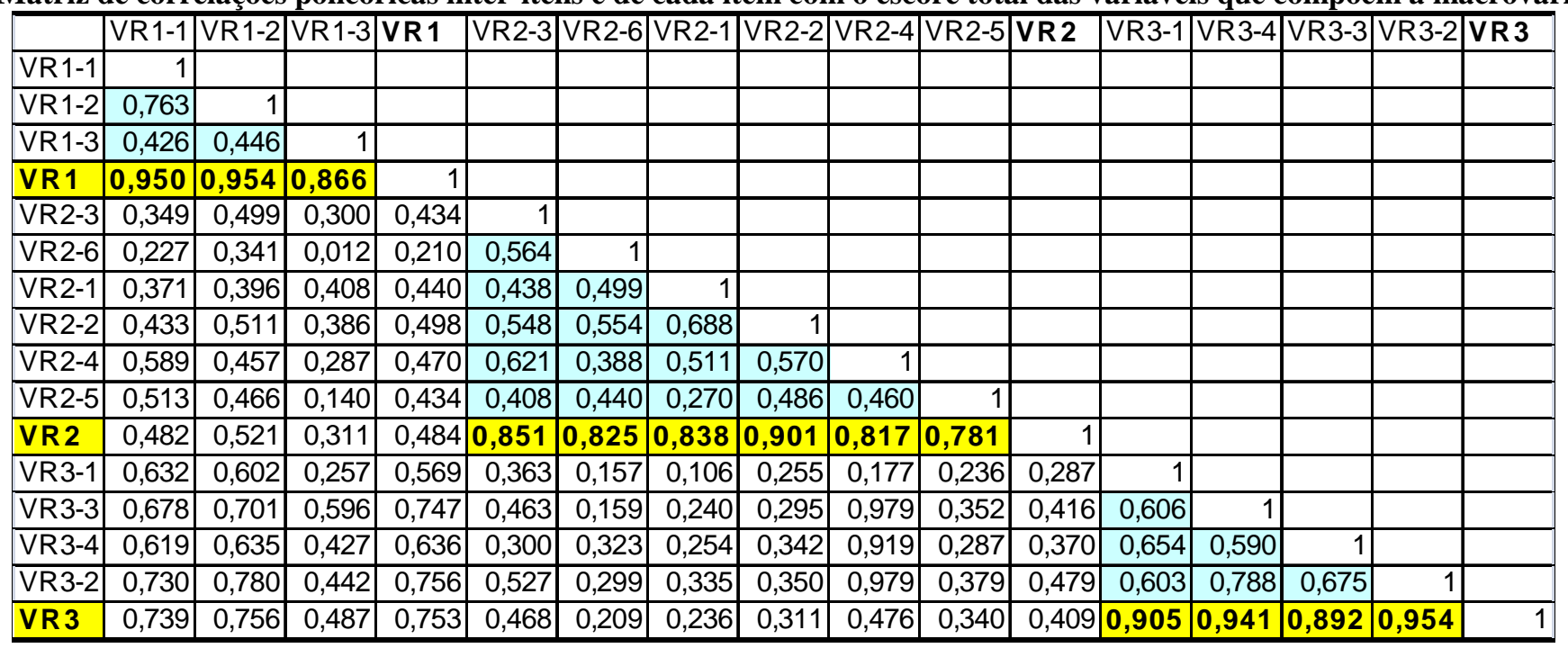

FONTE: a autora com base no reagrupamento dos dados dos Indicadores Ethos 2008

Tabela 2- Matriz de correlações policóricas inter-itens e de cada item com o escore total das variáveis que compõem a macrovariável ciclo

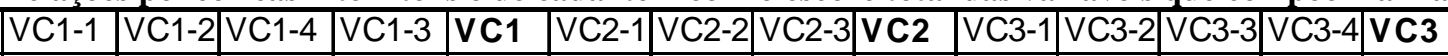

\begin{tabular}{|l|r|r|r|r|r|r|r|r|r|r|r|r|r|r|r|r|r|}
\hline VC1-1 & 1 & & & & & & & & & & & & & \\
\hline VC1-2 & 0,658 & 1 & & & & & & & & & & & & \\
\hline VC1-4 & 0,362 & 0,528 & 1 & & & & & & & & & & & \\
\hline VC1-3 & 0,980 & 0,986 & 0,471 & 1 & & & & & & & & & & \\
\hline VC1 & $\mathbf{0 , 9 1 5}$ & $\mathbf{0} 951$ & $\mathbf{0 , 8 9 3}$ & $\mathbf{1 , 0 0 0}$ & 1 & & & & & & & & & \\
\hline VC2-1 & 0,988 & 0,331 & 0,328 & 0,761 & 0,582 & 1 & & & & & & & & \\
\hline VC2-2 & 0,972 & 0,969 & 0,328 & 0,779 & 0,659 & 0,645 & 1 & & & & & & & \\
\hline VC2-3 & 0,565 & 0,314 & 0,999 & 0,521 & 0,704 & 0,382 & 0,345 & 1 & & & & & & \\
\hline VC2 & 0,776 & 0,434 & 0,684 & 0,808 & 0,749 & $\mathbf{0 , 9 4 5}$ & $\mathbf{0 , 9 2 0}$ & $\mathbf{0 , 8 9 4}$ & 1 & & & & & \\
\hline VC3-1 & 0,204 & 0,292 & 0,186 & 0,468 & 0,292 & 0,368 & 0,401 & 0,117 & 0,303 & 1 & & & & \\
\hline VC3-2 & 0,186 & 0,237 & 0,119 & 0,986 & 0,274 & 0,386 & 0,332 & $-0,066$ & 0,216 & 0,510 & 1 & & & \\
\hline VC3-3 & 0,195 & 0,175 & $-0,054$ & 0,979 & 0,168 & 0,437 & 0,346 & $-0,082$ & 0,222 & 0,446 & 0,880 & & & \\
\hline VC3-4 & 0,047 & 0,315 & 0,082 & 0,979 & 0,206 & 0,248 & 0,273 & $-0,129$ & 0,106 & 0,209 & 0,758 & 0,822 & & \\
\hline VC3 & 0,184 & 0,294 & 0,123 & 0,665 & 0,292 & 0,417 & 0,406 & $-0,014$ & 0,266 & $\mathbf{0 , 8 0 7}$ & $\mathbf{0 , 9 7 8}$ & $\mathbf{0 , 9 7 5}$ & $\mathbf{0 , 9 0 8}$ & \\
\hline
\end{tabular}

FONTE: a autora com base no reagrupamento dos dados dos Indicadores Ethos 2008. 
Tabela 3- Matriz de correlações policóricas inter-itens e de cada item com o escore total das variáveis que compõem a macrovariável diversidade \begin{tabular}{|l|l|l|l|l|l|l|l|l|l|l|l|l|l|l|l|l|l|l|l|l|l|}
\hline VD1-3 & VD1-4 & VD1-5 & VD1-1 & VD1-2 & VD1 & VD2-2 & VD2-1 & VD2-5 & VD2-3 & VD2-4 & VD2 & VD3-1 & VD3-2 & VD3-3 & VD3-4 & VD3 & VD4.1 & VD4-3 & VD4-4 & VD4-2 & VD4 \\
\hline
\end{tabular}

\begin{tabular}{|c|c|c|c|c|c|c|c|c|c|c|c|c|c|c|c|c|c|c|c|c|c|c|}
\hline & VD1-3 & VD1-4 & VD1-5 & |VD1-1 & VD1-2 & VD1 & VD2-2 & VD2-1 & VD2-5 & VD2-3 & VD2-4 & VD2 & VD3-1 & VD3-2 & VD3-3 & |VD3-4 & VD3 & VD4.1 & VD4-3 & |VD4-4 & |VD4-2 & VD4 \\
\hline VD1-3 & 1 & & & & & & & & & & & & & & & & & & & & & \\
\hline $\begin{array}{l}\text { VD1-4 } \\
\end{array}$ & 0,671 & 1 & & & & & & & & & & & & & & & & & & & & \\
\hline VD1-5 & 0,340 & 0,737 & 1 & & & & & & & & & & & & & & & & & & & \\
\hline $\begin{array}{l}\text { VD1-1 } \\
\end{array}$ & 0,129 & 0,066 & 0,461 & 1 & & & & & & & & & & & & & & & & & & \\
\hline VD1-2 & 0,256 & 0,408 & 0,264 & 0,722 & 1 & & & & & & & & & & & & & & & & & \\
\hline$\overline{\text { VD1 }}$ & 0,786 & 0,889 & 0,862 & 0,802 & 0,829 & $\overline{1}$ & & & & & & & & & & & & & & & & \\
\hline VD2-2 & 0,229 & 0,161 & 0,224 & 0,198 & 0,098 & 0,214 & 1 & & & & & & & & & & & & & & & \\
\hline VD2-1 & 0,212 & 0,007 & 0,008 & $-0,086$ & 0,151 & 0,096 & 0,503 & 1 & & & & & & & & & & & & & & \\
\hline VD2-5 & 0,020 & $-0,342$ & $-0,084$ & $-0,038$ & $-0,221$ & $-0,139$ & 0,114 & 0,494 & 1 & & & & & & & & & & & & & \\
\hline VD2-3 & 0,127 & 0,043 & $-0,103$ & $-0,024$ & $-0,100$ & $-0,021$ & 0,267 & 0,190 & 0,366 & $\overline{1}$ & & & & & & & & & & & & \\
\hline VD2-4 & 0,293 & $-0,126$ & $-0,165$ & 0,023 & 0,120 & 0,050 & 0,308 & 0,431 & 0,510 & 0,474 & 1 & & & & & & & & & & & \\
\hline$\overline{\text { VD2 }}$ & 0,230 & $-0,083$ & $-0,021$ & 0,016 & 0,037 & 0,060 & 0,775 & 0,872 & 0,805 & 0,706 & 0,846 & 1 & & & & & & & & & & \\
\hline VD3-1 & 0,326 & 0,220 & 0,183 & 0,284 & 0,168 & 0,299 & 0,269 & 0,364 & 0,228 & 0,292 & 0,198 & 0,345 & 1 & & & & & & & & & \\
\hline VD3-2 & 0,281 & 0,308 & 0,133 & 0,347 & 0,398 & 0,363 & 0,225 & 0,264 & 0,071 & 0,214 & 0,269 & 0,272 & 0,561 & 1 & & & & & & & & \\
\hline VD3-3 & 0,301 & 0,132 & 0,223 & 0,206 & 0,092 & 0,238 & 0,220 & 0,245 & 0,291 & 0,313 & 0,347 & 0,337 & 0,269 & 0,338 & 1 & & & & & & & \\
\hline VD3-4 & 0,479 & 0,512 & 0,211 & 0,157 & 0,248 & 0,397 & 0,218 & 0,400 & 0,145 & 0,218 & 0,331 & 0,337 & 0,505 & 0,542 & 0,554 & 1 & & & & & & \\
\hline VD3 & 0,403 & 0,353 & 0,213 & 0,258 & 0,238 & 0,363 & 0,291 & 0,373 & 0,218 & 0,551 & 0,343 & 0,411 & 0,855 & 0,881 & 0,811 & 0,910 & 1 & & & & & \\
\hline $\begin{array}{l}\text { VD4-1 } \\
\end{array}$ & 0,975 & $-0,136$ & 0,063 & 0,315 & $-0,024$ & 0,135 & 0,983 & 0,989 & 0,270 & 0,418 & 0,999 & 0,630 & 0,116 & 0,056 & 0,364 & $-0,033$ & 0,116 & 1 & & & & \\
\hline VD4-3 & $-0,049$ & $-0,011$ & 0,341 & 0,460 & 0,082 & 0,203 & 0,141 & 0,068 & 0,093 & 0,058 & $-0,024$ & 0,101 & 0,401 & 0,243 & 0,129 & 0,065 & 0,251 & 0,177 & 1 & & & \\
\hline VD4-4 & 0,270 & 0,103 & 0,346 & 0,148 & 0,057 & 0,245 & 0,135 & 0,169 & 0,082 & 0,019 & 0,099 & 0,148 & 0,237 & 0,113 & 0,203 & 0,196 & 0,201 & 0,972 & 0,642 & 1 & & \\
\hline VD4-2 & 0,089 & $-0,111$ & 0,125 & 0,197 & $-0,099$ & 0,048 & 0,322 & 0,301 & 0,518 & 0,214 & 0,327 & 0,466 & 0,274 & $-0,005$ & 0,142 & $-0,035$ & 0,115 & 0,993 & 0,214 & 0,322 & 1 & \\
\hline VD4 & 0,183 & 0,004 & 0,413 & 0,406 & 0,081 & 0,274 & 0,377 & 0,333 & 0,390 & 0,083 & 0,208 & 0,398 & 0,421 & 0,240 & 0,319 & 0,198 & 0,338 & 0,732 & 0,798 & 0,758 & 0,751 & \\
\hline
\end{tabular}

FONTE: a autora com base no reagrupamento dos dados dos Indicadores Ethos 2008. 
Tabela 4- Matriz de correlações policóricas inter-itens e de cada item com o escore total das variáveis que compõem a macrovariável equilíbrio dinâmico

\begin{tabular}{|c|c|c|c|c|c|c|c|c|c|c|c|c|c|c|c|c|c|c|}
\hline & VE1-1 & VE1-2 & VE1-3 & VE1 & VE2-1 & VE2-2 & VE2-3 & VE2-4 & VE2-5 & VE2-7 & VE2-6 & VE2 & VE3-1 & VE3-2 & VE3-3 & VE3-4 & VE3-5 & VE3 \\
\hline VE1-1 & 1 & & & & & & & & & & & & & & & & & \\
\hline VE1-2 & 0,223 & 1 & & & & & & & & & & & & & & & & \\
\hline VE1-3 & 0,156 & 0,240 & 1 & & & & & & & & & & & & & & & \\
\hline VE1 & 0,606 & 0,665 & 0,793 & 1 & & & & & & & & & & & & & & \\
\hline VE2-1 & $-0,048$ & $-0,216$ & 0,018 & 0,060 & 1 & & & & & & & & & & & & & \\
\hline VE2-2 & $-0,058$ & $-0,157$ & 0,014 & 0,016 & 0,727 & 1 & & & & & & & & & & & & \\
\hline VE2-3 & $-0,044$ & $-0,196$ & $-0,021$ & $-0,010$ & 0,694 & 0,861 & 1 & & & & & & & & & & & \\
\hline VE2-4 & 0,057 & $-0,188$ & 0,142 & 0,092 & 0,642 & 0,759 & 0,768 & 1 & & & & & & & & & & \\
\hline VE2-5 & $-0,150$ & $-0,157$ & 0,073 & 0,053 & 0,611 & 0,716 & 0,792 & 0,755 & 1 & & & & & & & & & \\
\hline VE2-7 & $-0,146$ & $-0,055$ & 0,105 & 0,063 & 0,586 & 0,642 & 0,629 & 0,716 & 0,685 & 1 & & & & & & & & \\
\hline VE2-6 & $-0,202$ & $-0,277$ & 0,038 & $-0,009$ & 0,539 & 0,607 & 0,683 & 0,617 & 0,641 & 0,685 & 1 & & & & & & & \\
\hline VE2 & $-0,094$ & $-0,210$ & 0,059 & 0,039 & 0,813 & 0,853 & 0,890 & 0,892 & 0,856 & 0,876 & 0,799 & 1 & & & & & & \\
\hline VE3-1 & $-0,097$ & $-0,280$ & \begin{tabular}{|l|}
$-0,024$ \\
\end{tabular} & 0,031 & 0,796 & 0,753 & 0,743 & 0,709 & 0,724 & 0,668 & 0,640 & 0,791 & 1 & & & & & \\
\hline VE3-2 & $-0,104$ & $-0,090$ & 0,107 & 0,055 & 0,549 & 0,681 & 0,695 & 0,707 & 0,651 & 0,690 & 0,636 & 0,743 & 0,679 & 1 & & & & \\
\hline VE3-3 & $-0,099$ & $-0,192$ & 0,112 & 0,039 & 0,543 & 0,625 & 0,642 & 0,693 & 0,673 & 0,660 & 0,638 & 0,715 & 0,711 & 0,896 & 1 & & & \\
\hline VE3-4 & $-0,054$ & $-0,082$ & 0,071 & 0,063 & 0,565 & 0,643 & 0,642 & 0,646 & 0,702 & 0,701 & 0,655 & 0,747 & 0,690 & 0,819 & 0,870 & 1 & & \\
\hline VE3-5 & $-0,048$ & $-0,065$ & 0,123 & 0,052 & 0,605 & 0,666 & 0,694 & 0,676 & 0,680 & 0,668 & 0,600 & 0,735 & 0,730 & 0,849 & 0,863 & 0,815 & 1 & \\
\hline VE & $-0,093$ & $-0,184$ & 0,082 & 0,062 & 0,685 & 0,739 & 0,743 & 0,749 & 0,750 & 0,718 & 0,683 & 0,833 & 0,866 & 0,938 & 0,961 & 0,924 & 0,942 & 1 \\
\hline
\end{tabular}

FONTE: a autora com base no reagrupamento dos dados dos Indicadores Ethos 2008. 


\subsection{Tratamento dos Dados}

Os procedimentos para tratamento dos dados foram realizados levando em consideração as limitações impostas pelo tipo de mensuração das variáveis - dados nominais com medidas binárias e dados ordinais. Na adoção dos diferentes processos de análise, utilizou-se o auxílio de softwares como o Excel e o Statistical Analysis Software (SAS), versão 9.1.3. Portanto, procedimentos estatísticos foram usados para que as analises tenham validade e aceitabilidade no meio científico.

Inicialmente foi realizada a análise descritiva para obter as frequências relativas e acumuladas dos indicadores das variáveis de estudo, contribuindo para a visualização dos dados disponíveis.

Para verificar o relacionamento existente entre as ferramentas de gestão para a sustentabilidade e os princípios ecológicos, optou-se por fazer uso de procedimentos de análise estatística multivariada, especificamente a técnica da regressão logística.

A técnica aplicada consiste em utilizar abordagens estatísticas nas quais se modelam a interdependência e a discriminação entre grupos de empresas. Pode-se dizer essa técnica que permite estabelecer a probabilidade de ocorrência de determinado evento e a importância da variável para esta ocorrência. Tal modelo opera sem o rigor dos pressupostos multivariados de normalidade, linearidade e homocedasticidade, exigindo apenas ausência de multicolinearidade e independência dos erros como pressupostos (COELHO; CORRAR, 2005).

Esse método, assim como as regressões linear e múltipla, estuda a relação entre uma variável resposta e uma ou mais variáveis independentes. A diferença entre estas técnicas de regressão se deve ao fato de que, na regressão logística, as variáveis dependentes estão dispostas em categorias, enquanto na regressão linear estas variáveis são dados contínuos. Outra diferença é que na regressão logística a resposta é expressa por meio de uma probabilidade de ocorrência, enquanto na regressão simples obtém-se um valor numérico (FIGUEIRA, 2006). 
Segundo Hair et al (2005), algumas justificativas para o uso da regressão logística referem-se à não necessidade de supor normalidade das variáveis, similaridade à regressão linear múltipla e a adequação a várias situações devido à sua robustez e maior generalidade.

Destaca-se que existem três procedimentos para tratar os dados a partir da regressão logística, conforme segue no Quadro 19. A escolha de uma das proposições depende do tipo de medição observada para os dados.

Quadro 19 - Procedimentos para utilização da regressão logística

\begin{tabular}{|c|c|c|}
\hline Tipo de Variável & Número de categorias & Características \\
\hline Binária & 2 & 2 níveis \\
\hline Ordinal & 3 ou mais & Ordenação natural de níveis \\
\hline Nominal & 3 ou mais & Não ordenação natural de níveis \\
\hline
\end{tabular}

FONTE: ONUSIC, 2009, p.91.

Neste estudo, tendo em vista os dados disponíveis, foi utilizada a regressão logística ordinal binominal. No modelo, com valores 0 e 1, o interesse está em estabelecer a razão de chances, ou odds ratio, que uma variável preditora tem sobre a probabilidade de uma variável resposta assumir o valor 1.

Ressalta-se, entretanto, que as variáveis resposta analisadas não são dicotômicas. Em geral, assumiram pelo menos 3 valores por serem formadas por três ou mais questões advindas do questionário de Indicadores Ethos 2008. Portanto, nos modelos de regressão, primeiramente, definiu-se variáveis dicotômicas a partir dos valores possíveis da variável em estudo. Por exemplo, se a variável assume os valores $0,1,2,3$ e 4, atribuiu-se 0 se ocorreu valores 0,1 ou 2 e valor 1 se a variável original tinha valor pelo menos 3. E, num segundo momento aplicouse a equação do modelo, conforme apresentado na Figura 8:

$$
\frac{\pi(x)}{1-\pi(x)}=\exp \left(\beta_{0}+\beta_{1} x_{1}+\cdots+\beta_{n} x_{n}\right)
$$

Figura 9 - Equação do modelo de regressão logística

O membro direito é chamado razão de chances: a probabilidade de sucesso (valor 1) dividida pelo seu complemento (probabilidade do valor 0, no caso dicotômico). As variáveis 
$x_{1}, x_{2}, \cdots, x_{n}$ são as variáveis preditoras ou independentes. O "logit" é o logaritmo da razão de chances, e tem um preditor linear, conforme a Figura 10:

$$
\log \left(\frac{\pi(x)}{1-\pi(x)}\right)=\beta_{0}+\beta_{1} x_{1}+\cdots+\beta_{n} x_{n}
$$

Figura 10 - Equação do logit da razão de chances

O modelo de regressão logística propõe que o logit da razão de chances da variável resposta seja predito linearmente pelas variáveis independentes. E, portanto, processada a partir de uma "razão de chance" dos dados observados e transforma esta razão de chance em logaritmo, o qual é igualado à equação esperada como variável reposta; regride-se então a equação pelo método da máxima verossimilhança (COELHO; CORRAR, 2005). É importante ressaltar que o processamento consiste em diversas tentativas até que se consiga o modelo com melhor significância estatística e mais adequado poder discriminatório.

$\mathrm{O}$ foco da interpretação está nos coeficientes de regressão $\beta_{1}, \beta_{2}, \cdots, \beta_{n}$, sendo que a presença de determinada variável preditora no modelo indica sua influência sobre a variável resposta. Destaca-se que o sinal do coeficiente é indicativo de um aspecto da maior relevância para o problema. Se o coeficiente for negativo, significa que a resposta positiva a alguma ferramenta de gestão efetiva nas empresas (variáveis preditoras) diminui a evidência de princípios ecológicos nas empresas (variáveis resposta). Já, se o coeficiente for positivo, isso implica que a existência de tal ferramenta aumenta a presença dos princípios ecológicos.

Outra informação apresentada nos resultados refere-se ao p-valor que está relacionado à probabilidade de se obter um valor de estatística amostral de teste no mínimo tão extremo como o que resulta dos dados amostrais, na suposição de a hipótese nula ser verdadeira (TRIOLA, 1998 apud ONUSIC, 2009). É relatada também a razão de chances, denominada de odds, que apresenta o quanto uma resposta positiva na variável preditora implica na razão de chances para a variável resposta.

Além da interpretação dos coeficientes significativos, há a consideração sobre a qualidade do ajuste. Em regressão logística, utiliza-se o teste de Hosmer-Lemeshow. Trata-se de um teste que associa os dados as suas probabilidades estimadas da mais alta à mais baixa, então faz um teste de qui-quadrado para determinar se as frequências observadas estão próximas das 
esperadas (ONUSIC, 2009). Para este teste, que mede a qualidade do ajuste realizado, é importante que se tenha um p-valor alto, isto é, não significativo.

\subsection{Limitações da Pesquisa}

Embora o questionário dos Indicadores Ethos seja um instrumento de medição estável com aplicação recursiva, não é universalmente considerado o melhor referencial para avaliação do estágio em que se encontram as práticas de responsabilidade socioambiental nas empresas. A precisão dos atributos estudados, ainda que bem delineada, está limitada ao questionário dos Indicadores Ethos. Dessa forma, a opção pela construção de um instrumento de investigação poderia contemplar outros aspectos importantes não abordados na composição das variáveis.

Mesmo com ampla base, há limitação no número de casos analisados uma vez que o questionário de Indicadores Ethos foi estruturado de modo que as empresas, caso respondam negativamente os indicadores de profundidade, não possuam acesso ao preenchimento das questões binárias que qualificam a resposta naquele indicador. Assim, muitos casos tiveram que ser excluídos da análise por apresentarem um conjunto incompleto de dados.

Além disso, as empresas informam voluntariamente o seu comprometimento com políticas e práticas de responsabilidade socioambiental e os dados não passam por um processo de checagem para certificação da veracidade das informações. Portanto, a falta de alguns dados para questões binárias, a confiabilidade das respostas e a amostragem não probabilística são as principais limitações do método de coleta.

O estudo apropriou-se de dados nominais com medidas binárias que são considerados por alguns autores como fracos uma vez que não sugerem qualquer ordem ou relação de distância e não têm origem aritmética, impossibilitando mensurações precisas (COOPER; SCHINDLER, 2003). Entretanto, o mesmo atendeu a pretensão do estudo ao classificar um conjunto de propriedades em um grupo de classes equivalentes.

Ressalta-se também que houve redução do número de princípios ecológicos a serem analisados, considerando o total de princípios apresentados por Capra $(1997,2002,2006)$. O 
estudo envolveu apenas quatro princípios, mas a perda de quantidade foi compensada por um amplo espectro de variáveis e questões inter-relacionadas. 


\section{ANÁLISE DOS RESULTADOS}

Neste capítulo são apresentados os resultados e discutidos seus pontos principais, tomando como base os objetivos e hipóteses orientadoras da pesquisa. Inicialmente, são relatados os resultados utilizando-se de análise univariada e bivariada descritiva. Na sequência, empregando a técnica da regressão logística, são destacadas as relações - estatisticamente significantes - entre as ferramentas de gestão para a sustentabilidade e os princípios ecológicos. As análises são realizadas de forma multivariada, buscando apreender detalhes específicos e obter uma visão integrada das variáveis preditoras e resposta em estudo. E, ao final, são relatadas as principais apreciações e discussões a respeito das hipóteses orientadoras.

\subsection{Análise Descritiva Univariada}

A análise descritiva foi realizada por tipo de variável em estudo. Não foi possível apresentar o perfil dos respondentes uma vez que o Instituto Ethos, na concessão do banco de dados dos Indicadores Ethos 2008, não forneceu informações que possibilitaram caracterizar as empresas respondentes. Sabe-se apenas que são grandes e médias empresas instaladas no Brasil. É importante destacar que, considerando os procedimentos utilizados na composição da amostra, especificado no item 3.2 desta tese, os casos em análise foram estratificados qualitativamente, sendo possível afirmar que as empresas estudadas já possuem envolvimento com a gestão socioambiental.

\subsubsection{Análise Descritiva das Variáveis Preditoras}

As variáveis preditoras são formadas por ferramentas que subsidiam o modelo de gestão para sustentabilidade e foram apresentadas aqui de forma univariada, a partir dos valores assumidos, conforme disposto na Tabela 5. 
Tabela 5 - Frequência presença das variáveis preditoras

\begin{tabular}{c|l|c|c}
\hline $\begin{array}{c}\text { CÓDIGO DA } \\
\text { VARIÁVEL }\end{array}$ & \multicolumn{1}{c}{ QUESTÃO } & Frequência & $\%$ \\
\hline PGLOBAL & $\begin{array}{l}\text { Orienta suas operações em concordância com os Princípios } \\
\text { do Pacto Global. }\end{array}$ & 222 & 67,07 \\
\hline OCDE & $\begin{array}{l}\text { Orienta suas operações em concordância com as diretrizes } \\
\text { para empresas multinacionais da OCDE. }\end{array}$ & 202 & 61,03 \\
\hline CONDUTA & Possui um código de conduta. & 279 & 84,29 \\
\hline BSOCIAL & $\begin{array}{l}\text { Elabora anualmente um balanço social que aborda } \\
\text { aspectos sociais, ambientais e econômicos. }\end{array}$ & 188 & 56,80 \\
\hline SA-OHSAS & $\begin{array}{l}\text { Foi certificada pela norma SA 8000, pela BS 8800, pela } \\
\text { OHSAS 18001 ou por norma equivalente. }\end{array}$ & 118 & 35,65 \\
\hline AA1000 & Aplica a norma AA 1000. & 78 & 23,56 \\
\hline ISO14000 & Possui certificação ambiental ISO 14001. & 147 & 44,41 \\
\hline AmpSTa 331
\end{tabular}

Amostra: 331 empresas

Observa-se entre as empresas pesquisadas que a ferramenta de gestão mais presente foi a existência de um código de ética organizacional (84,29\%), indicando que as empresas buscam conformar a conduta dos envolvidos no negócio. A presença do código de ética aponta para uma preocupação das empresas em criar uma declaração formal de expectativas, padrões e políticas comportamentais uniformes para que empregados e demais stakeholders possam saber o modo de agir adequado no ambiente organizacional.

Outras ferramentas de gestão também assimiladas por um grande número de pesquisadas foram os Princípios do Pacto Global $(67,07 \%)$ e as Diretrizes da OCDE $(61,03 \%)$. Ambos, proposto por instituições de relevância global, também podem ser caracterizados como um código de conduta, apresentando padrões de comportamento a serem seguidos pelas empresas. Pode-se inferir, a partir destes resultados, que as empresas pesquisadas acompanham e estão envolvidas com discussões de âmbito internacional uma vez que alinham seus propósitos de gestão a preceitos descritos em documentos que representam consensos internacionais. Os resultados também possibilitam afirmar que um grande número de pesquisadas são empresas multinacionais, uma vez que os Princípios da OCDE se aplicam a negócios caracterizados como tal.

Portanto, há uma grande preocupação dos gestores em definir padrões voluntários de comportamento para uma conduta empresarial responsável, indicando alinhamento com padrões éticos nos negócios. Os resultados corroboram com as afirmações realizadas pela Sustainability (2005) de que há sinais de enrijecimento da responsabilidade civil envolvendo novas áreas de comprometimento por parte das empresas, o que não era detectado há duas décadas. 
O balanço social, uma ferramenta de reporte de desempenho das ações já realizadas, foi elaborado por um pouco mais da metade das pesquisadas. Por ser uma ferramenta de gestão não obrigatória no Brasil, esse dado reforça o envolvimento das empresas estudadas com o tema socioambiental uma vez que, mesmo carecendo de pesquisas comprobatórias, sabe-se que um número muito reduzido de empresas publicam tais relatórios no ambiente empresarial nacional.

A ferramenta de gestão menos adotada foi a AA 1000, estando presente em $23,56 \%$ das empresas pesquisadas. Talvez por ser uma norma auditável, implicando em investimentos para implementação e por ter sido criada por uma organização não-governamental inglesa pouco conhecida no contexto de negócio brasileiro. Ressalta-se ainda que um número reduzido de empresa, num total de 35,65\% está certificada pelas normas SA 8000, BS 8800 ou OHSAS 18001, todas vinculadas à segurança, à saúde e às relações de trabalho.

Parece que as empresas estudadas reforçam a premissa assumida na metodologia de que a restrição no uso de casos com dados completos nos Indicadores Ethos 2008 possibilitou circunscrever a análise àquelas empresas que já possuem envolvimento com a gestão socioambiental, adotando inclusive ferramentas de apoio. Observou-se também que as pesquisadas já direcionam seu modelo de gestão para assumir novos princípios e comportamento diretivos. Entretanto, as ferramentas que implicam em mudanças de processos internos e certificação de práticas foram exibidas por um menor número de empresas.

\subsubsection{Análise Descritiva das Variáveis Resposta}

A descrição dos dados vinculados às variáveis respostas foram realizadas para cada uma das macrovariáveis em estudo, sendo apresentadas aqui de forma univariada.

\subsubsection{Análise Univariada da Macrovariável Rede}

A macrovariável rede busca identificar a existência de coordenação e arranjo das empresas de uma cadeia produtiva em aspectos socioambientais. Esta macrovariável é formada por treze questões advindas do questionário dos Indicadores Ethos 2008, subdivididas em três categorias de análise: a existência de programa de responsabilidade socioambiental para a 
cadeia de fornecedores (VR1), a adoção de critérios socioambientais para compras (VR2) e o monitoramento de posturas socioambientais de fornecedores (VR3), conforme apresentado na Tabela 6.

Tabela 6 - Frequência presença das questões pertencentes à macrovariável rede

\begin{tabular}{|c|c|c|c|}
\hline $\begin{array}{l}\text { CÓDIGO DA } \\
\text { VARIÁVEL }\end{array}$ & QUESTÃO & Frequência & $\%$ \\
\hline VR1 & \multicolumn{3}{|c|}{$\begin{array}{l}\text { Existência de programa de responsabilidade socioambiental para a cadeia de } \\
\text { fornecedores }\end{array}$} \\
\hline VR1-1 & $\begin{array}{l}\text { Possui política explícita ou programa específico de } \\
\text { responsabilidade social para a cadeia de fornecedores. }\end{array}$ & 151 & 45,62 \\
\hline VR1-2 & $\begin{array}{l}\text { Discute questões relacionadas à responsabilidade social com seus } \\
\text { fornecedores, visando o treinamento e adequação deles aos seus } \\
\text { critérios. }\end{array}$ & 146 & 44,11 \\
\hline VR1-3 & $\begin{array}{l}\text { Possui política de compras que privilegia fornecedores com } \\
\text { certificação socioambiental. }\end{array}$ & 195 & 58,91 \\
\hline VR2 & \multicolumn{3}{|l|}{ Adoção de critérios socioambientais para compras } \\
\hline VR2-1 & $\begin{array}{l}\text { Contrata fornecedores que comprovadamente tenham boa } \\
\text { conduta ambiental. }\end{array}$ & 253 & 76,44 \\
\hline VR2-2 & $\begin{array}{l}\text { Prioriza fornecedores engajados na busca da sustentabilidade das } \\
\text { florestas. }\end{array}$ & 153 & 46,22 \\
\hline VR2-3 & $\begin{array}{c}\text { Conhece a origem das matérias-primas, insumos e produtos } \\
\text { utilizados nas suas operações diárias e tem a garantia de que } \\
\text { nessa origem os direitos humanos e o meio ambiente são } \\
\text { respeitados. }\end{array}$ & 164 & 49,55 \\
\hline VR2-4 & $\begin{array}{c}\text { Adota critérios de compra que consideram a garantia de origem, } \\
\text { para evitar a aquisição de produtos piratas, falsificados ou frutos } \\
\text { de roubo de carga. }\end{array}$ & 313 & 94,56 \\
\hline VR2-5 & $\begin{array}{l}\text { Verifica a Lista Suja de Trabalho Forçado do Ministério do } \\
\text { Trabalho, antes de comprar ou contratar fornecedor. }\end{array}$ & 115 & 34,74 \\
\hline VR2-6 & $\begin{array}{l}\text { Busca o tratamento justo aos fornecedores, privilegiando o } \\
\text { pequeno fornecedor com remuneração justa em dia, programas de } \\
\text { qualificação e de transferência de tecnologia. }\end{array}$ & 222 & 67,07 \\
\hline VR3 & \multicolumn{3}{|l|}{ Monitoramento de posturas socioambientais de fornecedores } \\
\hline VR3-1 & $\begin{array}{l}\text { Produz relatório periódico com evidências de que questões } \\
\text { relacionadas à responsabilidade social estão sendo cumpridas e } \\
\text { implementadas na sua cadeia produtiva. }\end{array}$ & 95 & 28,70 \\
\hline VR3-2 & $\begin{array}{l}\text { Estabelece prazo formal para que os fornecedores entrem em } \\
\text { conformidade com seus critérios de responsabilidade social. }\end{array}$ & 108 & 32,63 \\
\hline VR3-3 & $\begin{array}{c}\text { Realiza visitas de inspeção das práticas de responsabilidade } \\
\text { social de seus fornecedores. }\end{array}$ & 102 & 30,82 \\
\hline VR3-4 & $\begin{array}{c}\text { Possui critérios socioambientais de seleção e avaliação de } \\
\text { fornecedores adotando a coleta de evidências de que cumprem as } \\
\text { exigências. }\end{array}$ & 34 & 10,27 \\
\hline
\end{tabular}

Amostra: 331 empresas

As práticas de gestão mais presentes nas empresas estudadas referem-se à (VR2-4) adoção de critérios de compra que consideram a garantia de origem para evitar a aquisição de produtos falsificados ou oriundos de roubo de cargas (94,56\%), seguida pela (VR2-1) contratação de fornecedores que comprovadamente tenham boa conduta ambiental (76,44\%). Ambas vinculadas à variável VR2 - Adoção de critérios socioambientais para compras. Isso indica, que a credibilidade de uma empresa e a sua legitimidade quando se fala em responsabilidade 
socioambiental não é construída isoladamente e pode ser influenciada pela imagem das outras organizações com as quais interagem. Conforme já destacado por Elkington (2001), Borger (2004) e Savitz (2007), as empresas vêm percebendo a necessidade de gerenciar a responsabilidade socioambiental numa perspectiva de cadeia para garantir a legitimidade e coerência com as ações já realizadas pela empresa.

Entre as práticas de gestão menos aplicadas estão a (VR3-4) existência de critérios socioambientais de seleção e avaliação de fornecedores, adotando a coleta de evidências $(10,27 \%)$ e a (VR3-1) produção de relatórios periódicos com evidência de que as questões socioambientais estão sendo implementadas na sua cadeia produtiva $(28,70 \%)$, ambas vinculadas à variável VR3 - Monitoramento de posturas socioambientais de fornecedores.

Observando essas duas práticas, parece haver uma inconsistência de informação por parte das empresas estudadas. A análise dos dados mostrou que um maior número de pesquisadas afirma produzir relatório periódico de reporte das práticas (VR3-1), em relação àquelas que possuem critérios e coleta efetiva de evidência (VR 3-4). Ressalta-se que na gestão das empresas a coleta de informações precede a elaboração do instrumento de relato das ações realizadas. Dessa forma, surge um questionamento: como as empresas conseguem relatar as práticas socioambientais implementadas por sua cadeia produtiva se não definiram os critérios utilizados na seleção e avaliação dos fornecedores? Um melhor entendimento da situação exige a elaboração de estudos complementares.

Dentre as práticas estudadas na macrovariável rede destaca-se também a VR2-6 e a VR1-3 nas quais mais da metade das pesquisadas assumiram privilegiar o pequeno fornecedor $(67,07 \%)$ e possuir um programa de compras que valoriza os fornecedores com certificações socioambientais $(58,91 \%)$. Esses resultados, juntamente com o grande número de resposta positiva a VR2-4, indicam que o critério de compra não está restrito unicamente ao fator preço e qualidade, como tradicionalmente ocorre no ambiente de negócios. Conforme já apontado por diferentes autores, vem se intensificando uma nova lógica de negócios calcada em conduta e comportamento dos agentes. (MACHADO FILHO; ZYLBERSZTAJN, 2004; GRAYSON; HODGES，2002; BORGER; KRUGLIANSKAS，2002; ASHLEY，2002; SAVITZ, 2007). 
Tabela 7 - Frequência de presença por categoria de análise da macrovariavel rede

\begin{tabular}{|c|c|c|}
\hline $\begin{array}{l}\text { CÓDIGO DA } \\
\text { VARIÁVEL }\end{array}$ & NOME DA VARIÁVEL & Média de Adoção (\%) \\
\hline VR1 & $\begin{array}{l}\text { Existência de programa de responsabilidade socioambiental } \\
\text { para a cadeia de fornecedores. }\end{array}$ & 49,54 \\
\hline VR2 & Adoção de critérios socioambientais para compras. & 61,43 \\
\hline VR3 & Monitoramento de posturas socioambientais de fornecedores. & 25,60 \\
\hline
\end{tabular}

Amostra: 331 empresas

Pode-se dizer, com base na Tabela 7, que embora muitas empresas estejam exigindo na seleção e contratação de fornecedores práticas de responsabilidade socioambiental (VR2), um menor número vem buscando desenvolvê-los proporcionando novas aprendizagens para que consigam atender aos recentes requerimentos. Além disso, um grande número ainda não possui mecanismos formais para monitorar a conformidade dos fornecedores com as exigências (VR3). Esse comportamento está em dissonância com as funções básicas da administração que inclui o controle como um dos elementos fundamentais da gestão.

\subsubsection{Análise Univariada da Macrovariável Ciclo}

A macrovariável ciclo pretende identificar práticas de gerenciamento sistêmico dos danos e impactos potenciais do ciclo da matéria de produtos e serviços gerados pela empresa sobre o ambiente. Esta macrovariável é composta por 11 questões presentes no questionário de Indicadores Ethos 2008, estruturadas em três categorias de análise: a redução do impacto ambiental nos processos internos (VC1), a concepção ecológica do produto e destinação pósconsumo (VC2) e a ecoeficiência (VC3), conforme apresentado na Tabela 8.

Observa-se que a prática de gestão mais implementada pelas empresas estudadas refere-se ao gerenciamento dos impactos dos produtos e processos sobre o meio ambiente a partir de um sistema de gestão padronizado e formalizado (VC1-2), com 78,55\% de respostas positivas. É possível perceber, entretanto, que a norma ISO 14000 não foi escolhida por um grande número de pesquisadas como o sistema padrão para estruturar o modelo de gestão ambiental uma vez que apenas $44,41 \%$ das empresas possuem esta certificação, conforme apresentado na Tabela 5 .

Tal resultado está em consonância com as observações encontradas por Rohrich e Cunha (2004), uma vez que afirmam que as organizações têm demonstrando comportamentos 
diferenciados quanto ao controle da gestão ambiental, mesmo quando possuem um sistema de gestão ambiental certificado. Cabe aqui um estudo para identificar qual tem sido o sistema de gestão padronizado utilizado pelas empresas que administram seus impactos sobre o meio ambiente.

Tabela 8 - Frequência presença das questões pertencentes à macrovariável ciclo

\begin{tabular}{|c|c|c|c|}
\hline $\begin{array}{c}\text { CÓDIGO DA } \\
\text { VARIÁVEL }\end{array}$ & QUESTÃO & Frequência & $\%$ \\
\hline VC1 & \multicolumn{3}{|l|}{ Redução do impacto ambiental nos processos internos } \\
\hline VC1-1 & $\begin{array}{l}\text { Assume compromisso e responsabilidade com os impactos } \\
\text { ambientais resultantes da atividade da empresa priorizando } \\
\text { políticas preventivas. }\end{array}$ & 246 & 74,32 \\
\hline VC1-2 & $\begin{array}{l}\text { Gerencia os impactos dos produtos e processos sobre o meio } \\
\text { ambiente a partir de um sistema de gestão padronizado e } \\
\text { formalizado. }\end{array}$ & 260 & 78,55 \\
\hline VC1-3 & $\begin{array}{l}\text { Possui sistema para minimizar entradas e saídas de materiais } \\
\text { adotando estratégias de reutilização e compensação ambiental } \\
\text { envolvendo o sistema produtivo. }\end{array}$ & 17 & 5,14 \\
\hline VC1-4 & $\begin{array}{l}\text { Gerencia os danos potenciais dos produtos e serviços adotando } \\
\text { medidas preventivas e corretivas quando detectados riscos de } \\
\text { falhas. }\end{array}$ & 222 & 67,07 \\
\hline VC2 & \multicolumn{3}{|l|}{ Concepção ecológica do produto e destinação pós-consumo } \\
\hline VC2-1 & $\begin{array}{l}\text { Assume compromisso e responsabilidade com os impactos } \\
\text { ambientais ao desenvolver novos negócios, levando em conta, } \\
\text { desde a concepção, os princípios da sustentabilidade }\end{array}$ & 105 & 31,72 \\
\hline VC2-2 & $\begin{array}{l}\text { Produz estudos de impacto em toda cadeia produtiva visando a } \\
\text { melhoria de seus processos e participa da destinação final dos } \\
\text { produtos e processo de pós-consumo. }\end{array}$ & 45 & 13,60 \\
\hline VC2-3 & $\begin{array}{c}\text { Gerencia os danos potenciais dos produtos e serviços } \\
\text { considerando o desenvolvimento sustentável e a ética como } \\
\text { dimensões importantes na concepção, reformulação, fabricação e } \\
\text { venda. }\end{array}$ & 131 & 39,58 \\
\hline VC3 & \multicolumn{3}{|l|}{ Ecoeficiência } \\
\hline VC3-1 & Possui iniciativas para uso de fontes de energia renovável. & 148 & 44,71 \\
\hline VC3-2 & $\begin{array}{l}\text { Possui sistema de monitoramento com metas específicas para } \\
\text { aumento da eficiência energética. }\end{array}$ & 183 & 55,29 \\
\hline VC3-3 & $\begin{array}{l}\text { Possui sistema de monitoramento com metas específicas para } \\
\text { redução do consumo de água. }\end{array}$ & 229 & 69,18 \\
\hline VC3-4 & $\begin{array}{l}\text { Possui sistema de monitoramento com metas específicas para } \\
\text { geração de resíduos sólidos. }\end{array}$ & 235 & 71,00 \\
\hline
\end{tabular}

Amostra: 331 empresas

As próximas práticas mais assimiladas foram, respectivamente, a (VC1-1) adoção de compromisso e responsabilidade com os impactos ambientais priorizando políticas preventivas $(74,32 \%)$ e a (VC3-4) existência de monitoramento com metas específicas para o gerenciamento de resíduos sólidos (71\%).

Também foram adotadas por mais da metade das pesquisadas as práticas nomeadas VC3-3, VC3-2 e VC1-4 que envolvem a existência de um sistema de monitoramento com metas para 
a redução do consumo de água $(69,18 \%)$, o aumento da eficiência energética $(55,29 \%)$ e o gerenciamento dos danos potenciais dos produtos e serviços adotando medidas preventivas e corretivas quando detectados riscos de falhas $(67,07 \%)$. O grande número de empresas que afirmou ter adotado essas práticas indica o envolvimento das pesquisadas com a ecoeficiência nos processos (VC3) e a redução do impacto ambiental (VC1).

Já as práticas menos disseminadas referem-se à (VC1-3) existência de um sistema de minimização de entradas e saídas de materiais no sistema produtivo envolvendo estratégias de reutilização e compensação ambiental $(5,14 \%)$ e a (VC2-2) elaboração de estudos de impacto em toda a cadeia compreendendo a destinação final dos produtos e processos de pós-consumo $(13,60 \%)$. Ambas indicam que as empresas estão pouco envolvidas com práticas mais integrativas que repensam o ciclo de vida do produto a partir do processo de produção e da logística como um todo. Abre-se espaço para uma maior necessidade de reflexão sobre a natureza das relações da empresa como o meio ambiente e a interdependência dos fenômenos.

Numa análise das três categorias que compreendem a macrovariável ciclo, observa-se que as empresas estudadas estão mais comprometidas com a VC3- Ecoeficiencia $(65,16 \%)$, seguida pela VC1 - Redução do impacto ambiental nos processos internos $(56,27 \%)$ e, finalmente, um menor nível de adoção das práticas que envolvem a VC2- Concepção ecologia do produto e destinação pós-consumo (28,30\%), conforme apresentado na Tabela 9.

Tabela 9 - Frequência de presença por categoria de análise da macrovariavel ciclo

\begin{tabular}{|c|c|c|}
\hline $\begin{array}{l}\text { CÓDIGO DA } \\
\text { VARIÁVEL } \\
\end{array}$ & NOME DA VARIÁVEL & Média de Adoção (\%) \\
\hline VC1 & Redução do impacto ambiental nos processos internos. & 56,27 \\
\hline $\mathrm{VC2}$ & Concepção ecológica do produto e destinação pós-consumo. & 28,30 \\
\hline VC3 & Ecoeficiência. & 65,16 \\
\hline
\end{tabular}

Amostra: 331 empresas

Diversos autores (PORTER; LINDE, 1999; INMAN, 2002; BARBIERI, 2007; NASCIMENTO et al, 2008) relatam que práticas de ecoeficiência levam a uma diminuição no consumo de insumos por unidade de produto, o que por sua vez ocasiona uma redução no custo de produção e aumenta a competitividade da empresa, podendo ser um importante fator motivador para o engajamento das mesmas. As empresas parecem estar envolvidas com o que 
Barbieri (2007) denomina de uso sustentável dos recursos, especificamente no que se refere à redução na fonte.

Entretanto, práticas atreladas a uma abordagem de ciclo de vida dos produtos, considerando as diferentes fases de produção, distribuição, utilização e o pós-consumo ainda possuem pouca adesão das empresas. Pode-se dizer que a atuação das empresas estudadas em relação à macrovariável ciclo parece estar vinculada a melhorias unidimensionais, sedimentadas por uma racionalidade instrumental. Há indícios de que as empresas ainda não contemplam um enfoque holístico. Todavia, diversos autores alertam que os benefícios para sustentabilidade dos sistemas naturais serão muito maiores se a preocupação com a prevenção e redução do uso de insumos também estiver presente durante a fase de projeto de produtos e processos, bem como nas etapas que constituem o ciclo de vida. (ELKINGTON, 2001; BARBIERI, 2007; HAWKEN et al, 2000; SAVITZ, 2007).

\subsubsection{Análise Univariada da Macrovariável Diversidade}

A macrovariável diversidade é constituída por 18 questões do questionário dos Indicadores Ethos 2008 e almejou identificar a existência de mecanismos para interação, comunicação e relacionamento com diferentes públicos, abrangendo a pluralidade no ambiente interno e associações junto aos stakeholders. Essa macrovariável apresenta-se subdividida em quatro categorias de análise, sendo: VD1 - Pluralidade e participação dos colaboradores na gestão; VD2 - Envolvimento com questões da comunidade e de interesse público; VD3 - Inserção da comunidade na rede de negócios e VD4 - Diálogo e comunicação com os públicos de relacionamento, conforme disposto na Tabela 10.

Quase a totalidade das empresas afirmou (VD4-1) estar aberta às críticas de grupos ou partes interessadas $(99,09 \%)$, indicando que um bom relacionamento junto aos stakeholders é um importante fator de gestão no atual contexto de negócio. Entretanto, somente 54,68\% delas já possuem políticas e processos de gestão específicos para realizar o diálogo e o engajamento das partes interessadas (VD4-2). Observa-se, portanto, que há intenções positivas quanto à maior interação com os diferentes públicos, mas faltam num grande número de casos a existência de ferramentas para a gestão deste propósito. Nesse sentido, Pace et al (2003) ressaltam que a incapacidade dos administradores atuarem de forma pró-ativa com os 
interlocutores de mercado pode gerar nas empresas dificuldade no entendimento correto das medidas de desempenho necessárias, reduzindo sua capacidade de previsão.

Tabela 10 - Frequência presença das questões pertencentes à macrovariável diversidade

\begin{tabular}{|c|c|c|c|}
\hline $\begin{array}{l}\text { CÓDIGO DA } \\
\text { VARIÁVEL }\end{array}$ & QUESTÃO & Frequência & $\%$ \\
\hline VD1 & \multicolumn{3}{|l|}{ Pluralidade e participação dos colaboradores na gestão } \\
\hline VD1-1 & $\begin{array}{c}\text { Possui políticas e mecanismos formais para ouvir, avaliar e } \\
\text { acompanhar posturas, preocupações e críticas dos empregados. }\end{array}$ & 296 & 89,43 \\
\hline VD1-2 & $\begin{array}{c}\text { Possui programa de incentivo e reconhecimento das sugestões } \\
\text { dos empregados para melhoria dos processos internos. }\end{array}$ & 213 & 64,35 \\
\hline VD1-3 & $\begin{array}{c}\text { Possui procedimentos específicos para melhorar a qualificação e } \\
\text { promover pessoas com deficiência derivados da política de } \\
\text { valorização da diversidade e não discriminação. }\end{array}$ & 122 & 26,86 \\
\hline VD1-4 & $\begin{array}{l}\text { Possui procedimentos específicos para melhorar a qualificação e } \\
\text { o desenvolvimento na carreira de empregados negros derivados } \\
\text { da política de promoção da equidade e não discriminação racial. }\end{array}$ & 69 & 20,85 \\
\hline VD1-5 & $\begin{array}{l}\text { Possui procedimentos específicos para melhorar a qualificação } \\
\text { das mulheres e promovê-las derivados da política de promoção } \\
\text { da equidade de gênero. }\end{array}$ & 126 & 38,07 \\
\hline VD2 & \multicolumn{3}{|c|}{ Envolvimento com questões da comunidade e de interesse público } \\
\hline VD2-1 & $\begin{array}{c}\text { Participa de comitês/conselhos locais ou regionais para discutir a } \\
\text { questão ambiental com o governo e a comunidade. }\end{array}$ & 173 & 52,27 \\
\hline VD2-2 & $\begin{array}{l}\text { Contribui para a preservação da diversidade por meio de políticas } \\
\text { específicas e projetos de conservação de áreas protegidas e/ou } \\
\text { programas de proteção a animais ameaçados. }\end{array}$ & 160 & 48,34 \\
\hline VD2-3 & $\begin{array}{l}\text { Gerencia os impactos da empresa na comunidade de entorno } \\
\text { através de uma política formal, envolvendo a comunidade na } \\
\text { resolução dos problemas. }\end{array}$ & 308 & 93,05 \\
\hline VD2-4 & $\begin{array}{c}\text { Possui política de relacionamento com organizações locais } \\
\text { participando da elaboração de implantação de projetos conjuntos. }\end{array}$ & 218 & 65,86 \\
\hline VD2-5 & $\begin{array}{l}\text { Possui políticas para liderança e influência social tendo membros } \\
\text { da alta administração envolvidos na articulação de fortalecimento } \\
\text { de propostas de caráter socioambiental. }\end{array}$ & 204 & 61,63 \\
\hline VD3 & \multicolumn{3}{|l|}{ Inserção da comunidade na rede de negócios } \\
\hline VD3-1 & $\begin{array}{l}\text { Inclui entre seus fornecedores indivíduos ou grupos da } \\
\text { comunidade, tais como cooperativas de pequenos produtores ou } \\
\text { de iniciativas solidárias, associações de bairro e organizações } \\
\text { com projetos de renda para grupos usualmente excluídos. }\end{array}$ & 150 & 45,32 \\
\hline VD3-2 & $\begin{array}{l}\text { Estimula a formação de rede ou cooperativas de pequenos } \\
\text { fornecedores, ajudando-os a se adequar a novos padrões de } \\
\text { fornecimento. }\end{array}$ & 128 & 38,67 \\
\hline VD3-3 & $\begin{array}{l}\text { Possui programas para empregar o maior número de moradores } \\
\text { do local onde está inserida, dando-lhes formação em cooperação } \\
\text { com sindicatos, ONGs ou autoridades públicas competentes. }\end{array}$ & 225 & 68,28 \\
\hline VD3-4 & $\begin{array}{c}\text { Possui prática de compras e investimentos para aprimorar o } \\
\text { desenvolvimento socioeconômico da comunidade em que está } \\
\text { presente. }\end{array}$ & 200 & 60,42 \\
\hline VD4 & \multicolumn{3}{|l|}{ Diálogo e comunicação com os públicos de relacionamento } \\
\hline VD4-1 & $\begin{array}{c}\text { Está aberta a críticas de grupos ou partes interessadas sobre a } \\
\text { natureza de seus processos, produtos ou serviços. }\end{array}$ & 328 & 99,09 \\
\hline VD4-2 & $\begin{array}{c}\text { Busca o diálogo e o engajamento das partes interessadas por } \\
\text { meio de ferramentas e políticas específicas, redefinindo políticas } \\
\text { e processos de gestão. }\end{array}$ & 181 & 54,68 \\
\hline VD4-3 & $\begin{array}{l}\text { Possui ouvidor de fornecedores ou função similar, para assegurar } \\
\text { uma relação de parceria com eles. }\end{array}$ & 171 & 51,66 \\
\hline VD4-4 & Possui um ouvidor do consumidor ou função similar. & 240 & 72,51 \\
\hline
\end{tabular}

Amostra: 331 empresas 
Um número elevado de empresa declarou (VD2-3) gerenciar seus impactos na comunidade de entorno (93,05\%), preocupando-se com críticas e externalidades advindas do local onde a empresa está instalada. Tal conduta reforça a afirmação realizada por Kreitlon e Quintella (2001), Cortina e Navarro (2005) e Machado Filho (2006) de que os gestores são induzidos a procurar uma imagem legítima almejando a reputação corporativa de modo a dedicarem-se a estratégias até pouco tempo atrás desnecessárias e negligenciadas.

Outra prática evidenciada pela grande maioria das empresas pesquisadas foi a (VD1-1) existência de mecanismos formais para ouvir, avaliar e acompanhar as preocupações e críticas dos empregados $(89,43 \%)$. Tal resultado está em consonância com discussões realizadas por diferentes pesquisadores que defendem como elemento fundamental para uma gestão responsável, o envolvimento interno e modelos de gestão mais colaborativos (BORGER, 2001; VELOSO, 2002; WERLANG, 2003; TACHIZAWA, 2004; ALIGLERI et al, 2009). Portanto, a mudança no macroambiente e as novas demandas sobre as empresas implicaram numa transformação da relação com o trabalhador.

A preocupação em conhecer as expectativas dos consumidores (VD4-4) também foi destacada por um grande número de empresas já que $72,51 \%$ delas possuem um ouvidor do consumidor ou função similar. Dessa forma, sugere-se que os principais públicos de relacionamento das empresas estão contemplados na gestão das pesquisadas indicando alinhamento com o modelo de gestão embasado na teoria dos stakeholders.

Destaca-se que embora 93,05\% das empresas afirmaram estar preocupadas com a comunidade de entorno (VD2-3) e 67,07\% delas dizerem privilegiar o pequeno fornecedor (VR2-6), apenas $38,67 \%$ das empresas estimulou a formação de rede ou cooperativas de pequenos fornecedores, auxiliando-os na adequação dos novos padrões de fornecimento (VD3-2). Parece que há pouco envolvimento das empresas com a aprendizagem de seus parceiros transferindo tecnologia e conhecimento para melhorar a gestão do negócio. Tal situação também já havia sido identificada na análise global da macrovariável ciclo (VD1 e VD2). Esta poderia ser uma importante contribuição das empresas para o desenvolvimento social da comunidade com geração de emprego e renda, conforme defendido por Mendonça (2007) e teóricos da economia solidária. 
Percebeu-se que os públicos tradicionalmente discriminados na sociedade brasileira também foram os que receberam menor atenção entre as práticas analisadas na macrovariável diversidade. A existência de procedimentos específicos para melhorar a qualificação, promovendo pessoas com deficiência (VD1-3) e empregados negros (VD1-4) estão entre as ações menos citadas sendo realizadas, respectivamente, 26,86\% e 20,85\%. Ambas estão vinculadas à VD1 - Pluralidade e participação dos colaboradores na gestão. Tal resultado reforça a necessidade de políticas governamentais para incentivar o investimento das empresas junto a esses públicos.

Tabela 11 - Frequência de presença por categoria de análise da macrovariavel diversidade

\begin{tabular}{|c|c|c|}
\hline $\begin{array}{l}\text { CÓDIGO DA } \\
\text { VARIÁVEL }\end{array}$ & NOME DA VARIÁVEL & Média de Adoção (\%) \\
\hline VD1 & Pluralidade e participação dos colaboradores na gestão. & 47,91 \\
\hline VD2 & $\begin{array}{l}\text { Envolvimento com questões da comunidade e de interesse } \\
\text { público. }\end{array}$ & 64,23 \\
\hline VD3 & Inserção da comunidade na rede de negócios. & 53,17 \\
\hline VD4 & Diálogo e comunicação com os públicos de relacionamento. & 69,48 \\
\hline
\end{tabular}

Amostra: 331 empresas

Examinando os dados a partir das categorias de análise que compõem a macrovariável diversidade, conforme apresentado na Tabela 11, observa-se que as práticas mais adotadas pelas empresas estão mais vinculadas à VD4 - Diálogo e comunicação com os públicos de relacionamento $(69,48 \%)$, seguida pela VD2 - Envolvimento com questões da comunidade e de interesse público $(64,23 \%)$. A pluralidade e participação dos colaboradores na gestão (VD1) foi a variável que recebeu menor atenção das empresas, principalmente pelo baixo envolvimento das mesmas em ações direcionadas para colaboradores com deficiência, discriminação racional e equidade de gênero no ambiente de trabalho.

\subsubsection{Análise Univariada da Macrovariável Equilíbrio Dinâmico}

A última macrovariável analisada foi o equilíbrio dinâmico que buscou identificar a existência de monitoramento de variáveis socioambientais na dinâmica de gestão. Essa macrovariável envolveu quinze questões presentes no questionário dos Indicadores Ethos 2008, distribuídas em três categorias de análise: VE1- Mecanismos de avaliação e monitoramento das relações com diferentes públicos de relacionamento; VE2- Avaliação do desempenho social; VE3Avaliação do desempenho ambiental. A macrovariável é formada por dados nominais com 
medidas binárias e dados ordinais, implicando numa descrição dos resultados por categoria de análise.

A VE1, conforme apresentada na Tabela 12, é formada por três questões que buscam identificar a existência de mecanismos de avaliação e monitoramento das relações da empresa com diferentes públicos. Um maior número de pesquisadas afirmou monitorar a diversidade de seu quadro de colaboradores (VE1-1) e a melhoria da qualidade ambiental dos processos (VE1-2). A existência de indicadores para monitorar os impactos causados por suas atividades na comunidade de entorno (VE1-3) só foi realizado por 43,20\% das empresas estudadas.

Tabela 12 - Frequência de presença das questões pertencentes à macrovariável equilíbrio dinâmico para a variável VE1

\begin{tabular}{|c|c|c|c|}
\hline $\begin{array}{l}\text { CÓDIGO DA } \\
\text { VARIÁVEL }\end{array}$ & QUESTÃO & Frequência & $\%$ \\
\hline VE1 & \multicolumn{3}{|c|}{$\begin{array}{l}\text { Mecanismos de avaliação e monitoramento das relações com diferentes públicos de } \\
\text { relacionamento }\end{array}$} \\
\hline VE1-1 & $\begin{array}{c}\text { Nos processos e ferramentas de gestão de pessoas, a empresa } \\
\text { insere quesitos para monitorar a diversidade de seu quadro e } \\
\text { possíveis desigualdades em relação aos segmentos em } \\
\text { desvantagem. }\end{array}$ & 274 & 82,78 \\
\hline VE1-2 & $\begin{array}{c}\text { Dispõe de processos para mapeamento e análise sistêmica para a } \\
\text { melhoria da qualidade ambiental. }\end{array}$ & 238 & 71,90 \\
\hline VE1-3 & $\begin{array}{c}\text { Possui indicadores para monitorar os impactos causados por suas } \\
\text { atividades na comunidade de entorno. }\end{array}$ & 143 & 43,20 \\
\hline
\end{tabular}

Amostra: 331 empresas

Tais dados parecem apontar algumas inconsistências no relato das empresas:

a) Mais de $80 \%$ das empresas afirmaram monitorar a diversidade de seu quadro de colaboradores (VE1-1), embora um número reduzido delas relatou possuir e procedimentos específicos para melhorar a qualificação e promover pessoas com deficiência, negros e mulheres (VD1-3, VD1-4 e VD1-5). Surge o seguinte questionamento: por que monitorar a diversidade, se não são implementadas práticas de gestão para a inserção de públicos discriminados no ambiente de negócios? Em gestão de negócios aprende-se que o monitoramento deve servir como uma atividade de suporte para readequar e reajustar processos visando a melhoria organizacional.

b) Mais de $70 \%$ das empresas asseguraram que dispõem de processos de mapeamento e análise sistêmica da qualidade ambiental das atividades (VE1-2), entretanto somente $13,60 \%$ afirmou produzir estudos de impacto gerados pela cadeia produtiva visando a melhoria de seus processos (VC2-2). Dessa forma, pergunta-se: como as empresas podem dispor de mapeamento e análise sistêmica de processos se não realizam estudos 
de impacto? O conhecimento da situação atual na forma de diagnóstico dos impactos é um elemento importante para subsidiar o processo de mapeamento e análise sistêmica.

c) Na pergunta nomeada de VD2-3 mais de 90\% das empresas afirmou gerenciar impactos na comunidade de entorno, entretanto somente 43,20\% delas afirmam possuir indicadores para monitorar os impactos (VE1-3). Portanto, questiona-se: como é possível gerenciar impactos se não estão definidos os critérios de avaliação? O acompanhamento de qualquer processo de gestão implica na definição de indicadores para que se possa mensurar o desempenho.

Tais questionamentos sugerem que Instituto Ethos solicite documentos comprobatórios das informações prestadas, como já é realizado na BM\&FBovespa na seleção das empresas pretendem fazer parte do Índice de Sustentabilidade Empresarial.

As variáveis VE2 e VE3 foram estruturadas a partir da análise de questões quantitativas com dados de razão. Conforme o desempenho relatado pela empresa de um ano em relação ao subsequente, as informações foram reagrupadas num formato ordinal indicando piora, manutenção ou melhora do desempenho. Destaca-se ainda que como as perguntas quantitativas presentes no questionário são consideradas opcionais, mesmo as não respostas (missing data) foram apreciadas. A pesquisadora procedeu desta forma, pois tal fato indica que as empresas não monitoram esse indicador, o que se torna uma informação importante para os objetivos propostos nesta macrovariável. Usou-se o valor -1 para codificar a nãoresposta, por ter conotação negativa para a avaliação dos desempenhos social e ambiental. Os dados obtidos estão discriminados na Tabela 13.

No que se refere ao desempenho social das empresas (VE2), observou-se que para muitas questões analisadas um número expressivo de respondentes não apresentou dados que comprovam formalmente o monitoramento efetivo da sua conduta. Os indicadores de desempenho são importantes, conforme já destacado por Pace et al (2003), porque eles permitem aos gestores "[...] ver onde o valor está sendo criado, onde são necessários investimentos e melhorias e onde as estratégias da empresa estão sendo bem sucedidas [...]" (p. 44).

Numa análise global da variável VE2 pode-se dizer que tais dados não foram disponibilizados por mais de $59 \%$ das empresas. Além disso, analisando as empresas que relataram seu 
desempenho, percebeu-se que apenas um pequeno número apresentou melhora no resultado de um ano para o outro.

Tabela 13 - Frequência presença das questões pertencentes à macrovariável equilíbrio dinâmico para as variáveis VE2 e VE3

\begin{tabular}{|c|c|c|c|c|c|}
\hline \multirow{2}{*}{$\begin{array}{l}\text { CÓDIGO } \\
\text { DA } \\
\text { VARIÁVEL }\end{array}$} & \multirow[b]{2}{*}{ QUESTÃO } & \multicolumn{4}{|c|}{$\begin{array}{c}\text { Desempenho obtido na série anual } \\
2007 / 2008 \\
\end{array}$} \\
\hline & & $\begin{array}{l}\text { Não } \\
\text { respondeu } \\
(\%)\end{array}$ & $\begin{array}{l}\text { Piorou } \\
(\%)\end{array}$ & $\begin{array}{l}\text { Manteve } \\
(\%)\end{array}$ & $\begin{array}{l}\text { Melhorou } \\
(\%)\end{array}$ \\
\hline VE2 & Avaliação do desempenho social & & & & \\
\hline VE2-1 & Total de menores aprendizes na empresa & 40,48 & 4,83 & 34,14 & 20,84 \\
\hline VE2-2 & Percentual de pessoas com deficiência na empresa & 48,34 & 5,44 & 32,33 & 13,90 \\
\hline VE2-3 & Percentual de pessoas com idade superior a 45 anos & 49,85 & 10,88 & 17,82 & 21,45 \\
\hline VE2-4 & $\begin{array}{c}\text { Divisão do menor salário da empresa pelo salário } \\
\text { mínimo vigente }\end{array}$ & 56,19 & 15,11 & 15,71 & 12,99 \\
\hline VE2-5 & Média de acidentes de trabalho por empregado/ano & 50,76 & 14,50 & 24,77 & 9,97 \\
\hline VE2-6 & $\begin{array}{c}\text { Percentual de reclamações em relação ao total de } \\
\text { ligações atendidas pelo SAC }\end{array}$ & 59,21 & 8,46 & 26,89 & 5,44 \\
\hline VE2-7 & $\begin{array}{l}\text { Percentual de empregados que realizam trabalho } \\
\text { voluntário na comunidade }\end{array}$ & 66,77 & 3,63 & 22,05 & 7,55 \\
\hline VE3 & Avaliação do desempenho ambiental & & & & \\
\hline VE3-1 & $\begin{array}{l}\text { Quantidade média de incidentes, autuações e/ou } \\
\text { multas por violação das normas de proteção } \\
\text { ambiental }\end{array}$ & 41,99 & 3,63 & 52,27 & 2,11 \\
\hline VE3-2 & Consumo anual de energia (em KWh) & 60,42 & 9,67 & 16,01 & 13,90 \\
\hline VE3-3 & Consumo anual de água (em m3) & 61,33 & 10,27 & 14,80 & 13,60 \\
\hline VE3-4 & $\begin{array}{c}\text { Volume médio anual de gases de efeito estufa } \\
\text { emitidos na atmosfera (ton) }\end{array}$ & 70,39 & 2,72 & 22,96 & 3,93 \\
\hline VE3-5 & $\begin{array}{l}\text { Quantidade anual (em ton) de resíduos sólidos } \\
\text { gerados (lixo, dejetos, entulhos) }\end{array}$ & 65,86 & 8,46 & 14,80 & 10,88 \\
\hline
\end{tabular}

Amostra: 331 empresas

Os dois indicadores sociais mais acompanhados pelas pesquisadas são o VE2-1 e VE2-2 que se referem ao total de menores aprendizes e percentual de pessoas com deficiência na empresa. Foram também esses dois indicadores que apresentaram maior número de empresas preocupadas com a melhora do desempenho. É interessante ressaltar que ambos estão vinculados à legislação vigente no âmbito nacional.

Os indicadores no quais as empresas mais regrediram numa análise longitudinal foram a divisão do menor salário da empresa pelo salário mínimo vigente e a média de acidentes de trabalho por empregado/ano (VE2-4 e VE2-5). Em relação à avaliação do desempenho social os resultados obtidos corroboram com a declaração realizada por Cipola et al (2008, p. 12) em um estudo sobre o mesmo tema no qual afirma que “[...] há grandes lacunas na evidenciação de aspectos sociais por parte das empresas." 
O monitoramento efetivo do desempenho ambiental também foi relatado por um número reduzido de empresas. Na média, quase $60 \%$ das pesquisadas não apresentou informações quantitativas sobre sua prática efetiva. É importante observar ainda que, embora um grande número de pesquisadas tenha afirmado possuir um sistema de monitoramento da eficiência energética, do consumo de água e da geração de resíduos sólido (VC3 - Ecoeficiência da macrovariável ciclo), muitas não responderam quantitativamente os valores obtidos.

O indicador ambiental mais relatado pelas empresas refere-se à (VE3-1) quantidade média de incidentes, autuações e/ou multas por violação das normas de proteção ambiental, sendo que para 52,25\% delas a empresa manteve o seu histórico. Já os dois indicadores com maior quantidade de respostas indicando piora no desempenho foram o (VE3-3) consumo anual de água e (VE3-2) o consumo anual de energia.

Pode-se dizer em relação à macrovariável equilíbrio dinâmico que os indicadores vinculados a objetos já legislados estão mais presentes na gestão das empresas sendo também os que apresentaram maiores percentuais de manutenção ou incremento no desempenho. Portanto, conforme já havia sido afirmado por Ribeiro e Kruglianskas (2009), as leis tem sido importantes indutoras de novas condutas das empresas instaladas no Brasil.

\subsubsection{Análise Global sobre a Adoção dos Princípios Ecológicos}

De modo geral, as empresas estudadas adotam práticas de gestão vinculadas a princípios ecológicos, embora entre eles apresentem variações na assimilação. Parece que nos últimos anos foram alterados processos e padrões de gestão para contemplar a interação das empresas com os indivíduos e os sistemas naturais. Pode-se dizer, a partir das definições operacionais utilizadas nesta tese (ver item 1.4), que há indícios de interações e propriedades convergentes entre as práticas empresariais e a estruturação dos ecossistemas.

Observou-se a partir do percentual médio de adoção, conforme Gráfico 1, que as empresas estão mais envolvidas com práticas relacionadas ao princípio ecológico da diversidade já percebendo a necessidade de interação, comunicação e relacionamento com diferentes públicos. A diversidade nas relações está em consonância com uma modelo de gestão que envolve os stakeholders. Salienta-se que tal forma de gerenciamento foi muito fomentada nos últimos anos em congressos de administração, revistas de gestão e cursos da área. 


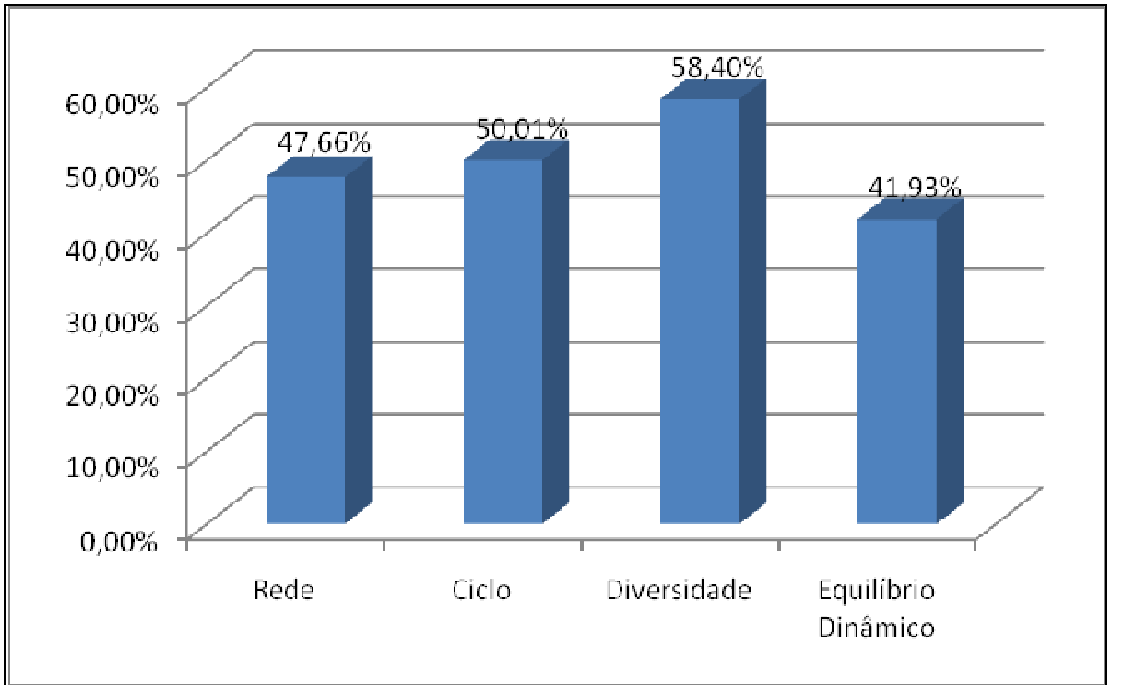

Gráfico 1 - Percentual médio das práticas adotadas nos princípios ecológicos estudados

A atuação das empresas alinhadas com práticas de gestão vinculadas ao princípio ecológico da diversidade, conforme visualizado nos resultados, pode facilitar a reorganização, a recuperação e a adaptação da empresa ao contexto. Dessa forma, ampliou-se a riqueza da complexidade das relações, buscando maior interação com públicos diversos para garantir sua longevidade.

Os princípios ecológicos rede e ciclo que estão diretamente vinculados ao ajustamento interno dos processos de gestão, envolvendo mais do que comunicação com os públicos de relacionamento, teve uma menor adesão por parte das empresas. Arranjos de cooperação, partilha de recursos, bem como a transposição de limites e fluxos de produção são exemplos de condutas que envolvem estes princípios ecológicos. Entretanto, houve um maior número de empresas que afirmou possuir canais de comunicação com os públicos de relacionamento (princípio ecológico da diversidade) do que aquelas que efetivamente alteraram padrões internos de atuação e entre os membros da comunidade de negócio (princípios ecológicos rede e ciclo). Os resultados indicam que as empresas ainda precisam avançar em relação à adoção dos princípios ecológicos transformando a interação e o novo padrão de comunicação em mudança de comportamento envolvendo um novo padrão de estruturação do negócio.

Já o princípio ecológico do equilíbrio dinâmico, na forma de mecanismos institucionais de realimentação capazes de responder sobre o desempenho da empresa em temas tradicionalmente não avaliados na gestão, foi o menos assimilado pelas pesquisadas. A normatividade das políticas e das ações precisam ser elevadas para que se insiram indicadores 
de avaliação das práticas adotadas. Parece que as empresas têm instituído poucos instrumentos de controle, dificultando feedbacks ao processo e um ajustamento da conduta. Além disso, percebeu-se um baixo nível de melhora do desempenho em relação aos aspectos sociais e ambientais. Odum e Barrett (2008) já haviam destacado a necessidade de mecanismos de retroalimentação, tanto negativos quanto positivos, como fundamentais para um desenvolvimento ordenado e de alta qualidade das comunidades humanas.

De modo geral, parece que no plano discursivo as preocupações com questões socioambientais estão presentes. Mas, a configuração organizacional ainda necessita avançar no que se refere a ações vinculadas a processos internos de gestão, indicadores de controle e melhoria do desempenho socioambiental.

\subsection{Análise das Relações entre as Variáveis Preditoras e Resposta}

$\mathrm{Na}$ análise das variáveis preditoras e resposta presentes desta pesquisa buscou-se identificar quais são as relações entre as ferramentas de gestão e os princípios ecológicos. Para conhecer esta relação, os resultados foram apresentados a partir das macrovariáveis resposta utilizandose da técnica multivariada de regressão logística que, segundo Hair et al (1998), é aplicada para estimar e compreender as diferença entre dois grupos de respondentes.

O modelo de análise foi constituído por uma variável pertencente à macrovariável resposta associada a sete variáveis preditoras. Este modelo foi replicado tantas vezes quantas são as variáveis que compõem as quatro macrovariáveis resposta em estudo.

As tabelas apresentam os níveis de significância dos coeficientes de correlação observados na relação entre as variáveis preditoras e resposta. A menção na tabela a determinadas variáveis preditoras indica sua associação com a variável resposta. Destaca-se que para efeito de interpretação dos coeficientes foram consideradas apenas as variáveis preditoras cujo nível de significância seja melhor que 5\%.

O teste de Hosmer-Lemeshow foi empregado para complementar a análise realizada. Tal testes foi desenvolvido para a avaliação de ajustamento em regressão logística, que se utiliza 
da distribuição qui-quadrado para examinar se há um bom ajuste entre dados esperados e observados (HAIR et al, 1998, p. 280).

\subsubsection{Macrovariável Ciclo}

A macrovariável ciclo é formada por três variáveis: VC1- Redução do impacto ambiental nos processos internos; VC2 - Concepção ecológica do produto e destinação pós-consumo e VC3 - Ecoeficiência. Os resultados encontrados foram apresentados por variável em estudo, possibilitando identificar as relações existentes.

A variável redução do impacto ambiental nos processos internos (VC1) é formada por quatro questões advindas do questionário de Indicadores Ethos 2008, podendo assumir cinco valores entre 0 e 4 . O ajuste realizado para a aplicação da técnica da regressão logística considerou 2 como ponto de corte. Portanto, às empresas que adotaram entre zero e uma prática atribuiu-se valor zero, considerando que a VC1 não está evidente nas suas operações. Atribuiu-se valor um, aceitando-se a presença da VC1 na gestão, quando a empresa adotou entre duas e quatro práticas. Segue a Tabela 14 que apresenta os coeficientes de regressão logística ordinal obtidos, bem como as variáveis preditoras relacionadas a VC1.

Tabela 14 - Coeficientes de regressão logística ordinal para a variável dicotomizada VC1

\begin{tabular}{l|l|l|l|l|l}
\hline Variável & $\mathrm{gl}$ & $\hat{\beta}_{i}$ & Erro padrão & $\mathrm{p}$-valor & Odds \\
\hline ISO14000 & 1 & 1.8225 & 0.3920 & $<.0001$ & 6.187 \\
\hline BSOCIAL & 1 & 1.0921 & 0.3140 & 0.0005 & 2.981 \\
\hline CONDUTA & 1 & 1.0310 & 0.3665 & 0.0049 & 2.804 \\
\hline PGLOBAL & 1 & 0.8023 & 0.4161 & 0.0538 & 2.231 \\
\hline OCDE & 1 & -0.5139 & 0.4262 & 0.2279 & 0.598 \\
\hline
\end{tabular}

A estatística $\hat{\beta}_{i}$ indica o impacto da desigualdade $\mathrm{e}^{\mathrm{z}}$ de uma variação em uma das variáveis, mantendo as demais constantes. Observa-se a partir da tabela um relevante coeficiente de regressão cinco variáveis preditoras, embora apenas três delas tenham o padrão de significância aceitável nesta tese, sendo elas: a norma ISO 14000, a publicação do Balanço Social e a existência de um Código de Conduta. Dentre essas, a norma ISO 14000 foi a ferramenta de gestão mais relevante, significando que a sua evidência na empresa aumenta a razão de chances de existência da VC1 em 6,18, em relação ao nível zero.

Portanto, pode-se dizer que quando presentes, estas três ferramentas de gestão potencializam o envolvimento e o gerenciamento dos impactos ambientais resultantes dos processos e 
atividades da empresa. As demais ferramentas de gestão não são significativas para a assimilação de práticas de redução dos impactos ambientais nos processos internos.

O teste de Hosmer-Lemeshow que analisa a capacidade preditiva do modelo associando as probabilidades estimadas da mais alta à mais baixa para determinar se as frequências observadas estão próximas das esperadas foi utilizado para complementar a análise. O modelo final resultou em três das sete variáveis preditoras estudadas, sendo elas: ISO 14000, Código de Conduta e Balanço Social. Em conjunto, estas variáveis explicam 83,3\% da presença da VC1 nas empresas pesquisadas. Estatisticamente, a hipótese de proporcionalidade da razão de chances ao nível da variável resposta não é negada, indicando boa qualidade do ajuste, com um p-valor de 0.1787 .

A segunda variável estudada no princípio ecológico ciclo refere-se à concepção ecológica do produto (VC2). Essa pode assumir quatro valores entre 0 e 3, usando 2 como ponto de corte. Segue a Tabela 15 na qual estão descritas as estimativas dos parâmetros, erro padrão, p-valor e estimativa pontual da razão de chances obtidos através da regressão logística ordinal, bem como as variáveis preditoras que se apresentam relacionadas a VC2.

Tabela 15 - Coeficientes de regressão logística ordinal para a variável dicotomizada VC2

\begin{tabular}{l|l|l|l|l|l}
\hline Variável & $\mathrm{gl}$ & $\hat{\beta}_{i}$ & Erro padrão & $\mathrm{p}$-valor & Odds \\
\hline ISO14000 & 1 & 0.7617 & 0.2861 & 0.0078 & 2.142 \\
\hline BSOCIAL & 1 & 0.6057 & 0.3156 & 0.0550 & 1.833 \\
\hline CONDUTA & 1 & 1.2695 & 0.6274 & 0.0430 & 3.559 \\
\hline AA1000 & 1 & 0.5857 & 0.3029 & 0.0532 & 1.796 \\
\hline PGLOBAL & 1 & 0.5506 & 0.3449 & 0.1104 & 1.734 \\
\hline
\end{tabular}

As variáveis preditoras norma ISO 14000 e a existência de um Código de Conduta foram as mais fortemente associadas à preocupação da empresa com a concepção ecológica do produto. O código de conduta potencializa a evidência de presença da VC2 em 3,55 e a norma ISO 14000 em 2,14.

Pode-se inferir, portanto, que as empresas que já adotaram tais ferramentas de gestão têm se preocupado com os efeitos do ciclo de vida dos seus produtos e serviços no meio ambiente e buscam a melhoria dos seus processos numa gestão mais holística de impactos e soluções. 
A partir do teste de Hosmer-Lemeshow, comparando-se as probabilidades preditas com as respostas observadas, infere-se que as mesmas variáveis preditoras relacionadas à VC1 (ISO 14000, Código de Conduta) são estatisticamente importantes e associadas à VC2. O teste apresentou um percentual de concordância do modelo de 75,5\% e um p-valor de 0.7806 , indicando um bom ajuste.

A Tabela 16, a seguir, discrimina os coeficientes de regressão logística bem como as variáveis preditoras para a VC3 - "ecoeficiência”. Esta variável foi avaliada a partir da quatro questões, assumindo cinco valores entre 0 e 4 . Utilizou-se 2 como ponto de corte.

A partir dos dados obtidos, é possível afirmar que a certificação ISO 14000 e a existência de um Código de Conduta na empresa foram as únicas ferramentas que evidenciaram relação positiva com a ecoeficiência (VC3). Tais ferramentas também possuem associação significativa com a VC1 e VC2, sendo que aumentam a razão de chances do envolvimento da empresa com a VC3 em 2,34 e 1,88, respectivamente.

Tabela 16 - Coeficientes de regressão logística ordinal para a variável dicotomizada VC3

\begin{tabular}{l|l|l|l|l|l}
\hline Variável & $\mathrm{gl}$ & $\hat{\beta}_{i}$ & Erro padrão & $\mathrm{p}$-valor & Odds \\
\hline CONDUTA & 1 & 0.6332 & 0.3208 & 0.0484 & 1.884 \\
\hline ISO14000 & 1 & 0.8532 & 0.3314 & 0.0100 & 2.347 \\
\hline SA-OHSAS & 1 & -0.8028 & 0.3349 & 0.0165 & 0.448 \\
\hline
\end{tabular}

As normas SA8000/OHSAS18001/BS8800 também estão relacionadas à variável em estudo, apresentando associação negativa. Isto é, comparando a presença e ausência das normas SA8000/OHSAS18001/BS8800 entre as pesquisadas, observa-se que sua presença reduz em $44,8 \%$ a probabilidade de envolvimento da empresa com práticas de ecoeficiência. Talvez porque tais normas tenham o seu escopo direcionado para a segurança, saúde e condições de trabalho, levando a empresa a negligenciar seu desempenho ambiental.

No teste de Hosmer-Lemeshow é possível observar um percentual de concordância em 72,5\% dos casos e um p-valor de 0.1479 , indicando um bom ajuste.

Numa análise das variáveis preditoras em relação à macrovariável ciclo pode-se observar que a existência de um Código de Conduta e a certificação ISO 14000 foram as únicas ferramentas de gestão que aumentam a presença das práticas nas três categoriais analisadas, 
conforme disposto no Quadro 20. Consequentemente, é possível deduzir que as empresas que as possuem já estão estruturando os seus negócios numa perspectiva de ciclo, isto é, envolvendo-se num gerenciamento sistêmico dos danos e impactos potenciais dos materiais, produtos e serviços, gerados pela empresa sobre o ambiente.

A pesquisadora já esperava tal relação entre a macrovariável ciclo e a norma de certificação ISO 14000, uma vez que, para a obtenção desta certificação, as empresas precisam melhorar seus processos e procedimentos de gestão ambiental, o que está diretamente relacionado às perguntas que compõem esta macrovariável. Já a correlação do código de conduta com a macrovariável ciclo foi percebida como uma interessante informação indicando que a presença de tal instrumento de gestão vem contribuindo para alterar os processos internos da empresa. Tal fato contraria a afirmação de alguns estudiosos da área de que o código de conduta é apenas uma peça de marketing.

Quadro 20 - Presença das variáveis preditoras relativas à macrovariável ciclo, com indicação do sinal da estimativa, ou não-significância.

\begin{tabular}{|c|c|c|c|}
\hline \multirow{2}{*}{ Variável Preditora } & \multicolumn{2}{|c|}{ Variável Resposta (presença no modelo) } \\
\cline { 2 - 4 } & VC1 & VC2 & VC3 \\
\hline PGLOBAL & Não significativo & Não significativo & \\
\hline OCDE & Não significativo & & Sim, $\mathrm{p} \leq 0,05$ \\
\hline CONDUTA & Sim, $\mathrm{p} \leq 0,01$ & Sim, $\mathrm{p} \leq 0,05$ & \\
\hline BSOCIAL & Sim, $\mathrm{p} \leq 0,01$ & Não significativo & Sim, negativo $\mathrm{p} \leq 0,05$ \\
\hline SA-OHSAS & & & Sim, $\mathrm{p} \leq 0,01$ \\
\hline AA1000 & & Não significativo & Sim, $\mathrm{p} \leq 0,01$ \\
\hline ISO14000 & Sim, $\mathrm{p} \leq 0,01$ & & \\
\hline
\end{tabular}

Observou-se também que os princípios da OCDE e a certificação AA 1000 não possuem relação significativa com nenhuma das três dimensões analisadas. Isso pode ser explicado uma vez que o escopo de tais ferramentas não abrange, diretamente, aspectos vinculados à melhoria dos processos internos para o uso mais eficiente de recursos naturais.

\subsubsection{Macrovariável Rede}

A análise das relações existentes entre ferramentas de gestão e práticas da macrovariável rede também serão analisadas a partir das três variáveis VR1 - Existência de programa de responsabilidade socioambiental para a cadeia de fornecedores; VR2 - Adoção de critérios 
sociambientais para compras e VR3 - Monitoramento das posturas socioambientais de fornecedores.

A variável VR1 que se refere à existência de programas de responsabilidade social para a cadeia de fornecedores pode assumir quatro valores entre 0 e 3 , usando dois como ponto de corte. Portanto, às empresas que adotaram entre zero e uma prática atribuiu-se valor zero, considerando que a VR1 não está evidente nas suas operações. Já às empresas que assumiram entre duas e três práticas, atribuiu-se valor um, aceitando-se a presença da VR1 na gestão. Segue a Tabela 17 na qual estão descritas as estimativas dos parâmetros, erro padrão, p-valor e estimativa pontual da razão de chances obtidos através da regressão logística ordinal, bem como as variáveis preditoras que se apresentam relacionadas a VR1.

Tabela 17 - Coeficientes de regressão logística ordinal para a variável dicotomizada VR1

\begin{tabular}{l|l|l|l|l|l}
\hline Variável & $\mathrm{gl}$ & $\hat{\beta}_{i}$ & Erro padrão & $\mathrm{p}$-valor & Odds \\
\hline PGLOBAL & 1 & 0.9091 & 0.2655 & 0.0006 & 2.482 \\
\hline SA-OHSAS & 1 & 0.6313 & 0.3018 & 0.0365 & 1.880 \\
\hline AA1000 & 1 & 0.7694 & 0.2903 & 0.0081 & 2.159 \\
\hline BSOCIAL & 1 & -0.4755 & 0.2579 & 0.0453 & 0.622 \\
\hline ISO14000 & 1 & 0.3827 & 0.2967 & 0.1970 & 1.466 \\
\hline
\end{tabular}

A adoção dos Princípios do Pacto Global e da norma AA 1000, nesta ordem, possuem associação mais significativa com a existência de programas de responsabilidade socioambiental para a cadeia de fornecedores. A presença de tais ferramentas de gestão potencializa a existência da VR1 em 2,48 e 2,15, respectivamente.

Também foram verificadas associações significativas para a presença das normas SA8000/OHSAS18000/BS8800 e a publicação de Balanço Social, com logaritmo de razão de chances menos expressivos. Destaca-se que este último possui coeficiente $\hat{\beta}_{i}$ negativo, ou seja, há uma relação negativa entre a VR2 e a publicação do relatório.

Dessa forma, o modelo final resultou na relação com quatro das sete variáveis preditoras estudadas, sendo elas: ser signatária dos Princípios do Pacto Global, possuir a norma AA 1000, possuir a norma SA8000/OHSAS18000/BS8800 e publicar Balanço Social. Comparando as probabilidades preditas com as respostas observadas e buscando analisar a qualidade do ajuste realizado, foi utilizado o teste de Hosmer-Lemeshow. Em conjunto, essas 
variáveis explicam 72,8\% da presença da VR1 nas empresas estudadas. O teste tem um pvalor de 0.6886 , indicando um bom ajuste.

A segunda variável estudada para a macrovariável rede refere-se à adoção de critérios socioambientais para compras (VR2). Ela foi avaliada a partir de seis questões presentes no questionário dos Indicadores Ethos 2008, podendo assumir sete valores entre 0 e 6, usando 3 como ponto de corte.

Conforme apresentado na Tabela 18, seis das sete variáveis preditoras apresentou relação com a VR2, sendo que cinco delas com associações estatisticamente significativas. Adotar um Código de Conduta, ser signatária dos Princípios do Pacto Global e possuir a norma AA 1000 expressaram associação positiva. Logo, comparando-se a presença e a ausência de tais ferramentas em relação a VR2, observou-se que a probabilidade de existência de critérios socioambientais para compras é aumentada 3,23 quando adota um Código de Conduta, 2,12 por ser signatária do Pacto Global e 2,05 quando possui a norma AA 1000.

Tabela 18 - Coeficientes de regressão logística ordinal para a variável dicotomizada VR2

\begin{tabular}{l|l|l|l|l|l}
\hline Variável & $\mathrm{gl}$ & $\hat{\beta}_{i}$ & Erro padrão & $\mathrm{p}$-valor & Odds \\
\hline CONDUTA & 1 & 1.1752 & 0.3587 & 0.0011 & 3.239 \\
\hline BSOCIAL & 1 & -0.8672 & 0.2956 & 0.0033 & 0.420 \\
\hline AA1000 & 1 & 0.7218 & 0.3443 & 0.0360 & 2.058 \\
\hline OCDE & 1 & -0.8609 & 0.3859 & 0.0257 & 0.423 \\
\hline PGLOBAL & 1 & 0.7553 & 0.3737 & 0.0433 & 2.128 \\
\hline SA-OHSAS & 1 & -0.3759 & 0.2802 & 0.1797 & 0.687 \\
\hline
\end{tabular}

Já a publicação de Balanço Social e a adoção dos Princípios da OCDE apresentaram relevante associação negativa. Isto é, a evidência destas duas ferramentas reduz em aproximadamente $40 \%$ a possibilidade de envolvimento da empresa com a VD2.

Mais uma vez, a publicação do Balanço Social foi significativamente vinculada a um menor comprometimento da empresa com a adoção das práticas. Tal relação negativa também já havia sido encontrada na VR1. Para um melhor entendimento é importante realizar estudos complementares envolvendo outros aspectos e práticas de âmbito organizacional interno de modo a conhecer possíveis elementos influentes em tal relação encontrada.

O modelo final foi formado pelas variáveis preditoras Código de Conduta, Balanço Social, Princípios da OCDE, Pacto Global e norma AA 1000. O teste de Hosmer-Lemeshow 
apresenta um percentual de concordância de 70,8\% dos casos com um p-valor é 0.6657. Dessa forma, a hipótese de proporcionalidade da razão de chances ao nível da variável resposta não é negada.

A última variável resposta da macrovariável rede compreende o monitoramento das posturas socioambientais dos fornecedores (VR3). A variável pode assumir cinco valores, entre zero e quatro, tendo 2 como ponto de corte. Segue a Tabela 19, que apresenta os coeficientes de regressão logística ordinal obtidos, bem como as variáveis preditoras relacionadas a VR3.

Tabela 19 - Coeficientes de regressão logística ordinal para a variável dicotomizada VR3

\begin{tabular}{l|l|l|l|l|l}
\hline Variável & $\mathrm{gl}$ & $\hat{\beta}_{i}$ & Erro padrão & $\mathrm{p}$-valor & Odds \\
\hline OCDE & 1 & 0.7545 & 0.2991 & 0.0117 & 2.127 \\
\hline SA-OHSAS & 1 & 0.6251 & 0.2606 & 0.0165 & 1.868 \\
\hline AA1000 & 1 & 0.6837 & 0.2858 & 0.0167 & 1.981 \\
\hline CONDUTA & 1 & 0.7327 & 0.4452 & 0.0998 & 2.081 \\
\hline
\end{tabular}

Os princípios da OCDE se destacaram como a ferramenta de gestão que apresentou relação positiva mais forte para o monitoramento das posturas socioambientais de fornecedores. Sua existência potencializa a presença da VR3 em 2,12. Talvez porque as empresas que endossam esta ferramenta estão envolvidas com o comércio internacional e, portanto, mais suscetíveis a críticas e riscos de reputação. Tal situação pode induzir o rastreamento das ações realizadas por seus parceiros de negócio.

O uso da técnica da regressão logística também indicou correlação com grau de significância para a presença das normas SA8000/OHSAS18000/BS8800 e da norma AA 1000. Sendo que a adoção destas aumenta a razão de chances de monitoramento da postura de fornecedores em 1,86 e 1,98, respectivamente. Tal fato pode ser explicado, uma vez que estas certificações exigem que as empresas assumam compromissos e conduta ética nas transações com outras organizações envolvendo os fornecedores.

Portanto, as variáveis preditoras estudadas relacionadas à VR3 foram: Princípios da OCDE, SA8000/OHSAS18000/BS8800 e norma AA 1000. No teste de Hosmer-Lemeshow tem-se um percentual de concordância do modelo em 75,4\% dos casos e um p-valor de 0.8064 , indicando um bom ajuste. 
Numa análise global das variáveis preditoras em relação à macrovariável rede, conforme destacado no Quadro 21, pode-se dizer que apenas a norma AA 1000 foi significativa para as três dimensões analisadas. Além disto, as ferramentas de gestão que se apresentam fortemente associadas às dimensões da macrovariável ciclo (CONDUTA e ISO14000), parecem estar pouco associadas à macrovariável rede.

Quadro 21 - Presença das variáveis preditoras relativas à macrovariável rede, com indicação do sinal da estimativa, ou não-significância.

\begin{tabular}{|c|c|c|c|}
\hline \multirow{2}{*}{ Variável Preditora } & \multicolumn{3}{|c|}{ Variável Resposta (presença no modelo) } \\
\cline { 2 - 4 } PGLOBAL & VR1 & VR2 & VR3 \\
\hline OCDE & & Sim, $p \leq 0,0105$ & \\
\hline CONDUTA & & Sim, negativo $p \leq 0,05$ & Sim, $p \leq 0,05$ \\
\hline BSOCIAL & Sim, negativo $p \leq 0,05$ & Sim, negativo $p \leq 0,01$ & Não significativo \\
\hline SA-OHSAS & Sim, $p \leq 0,05$ & Não significativo & Sim, $p \leq 0,05$ \\
\hline AA1000 & Sim, $p \leq 0,01$ & Sim, $p \leq 0,05$ & Sim, $p \leq 0,05$ \\
\hline ISO14000 & Não significativo & & \\
\hline
\end{tabular}

\subsubsection{Macrovariável Diversidade}

A macrovariável diversidade é formada por quatro variáveis: VD1 - Pluralidade e participação dos colaboradores na gestão; VD2 - Envolvimento com questões da comunidade e de interesse público; VD3 - Inserção da comunidade na rede de negócios e VD4 - Diálogo e comunicação com os públicos de relacionamento. Os resultados encontrados foram apresentados por variável em estudo, possibilitando identificar as relações existentes.

A variável pluralidade e participação dos colaboradores na gestão (VD1) pode assumir seis valores, entre 0 e 5 , usando três como ponto de corte. Portanto, foi realizado um ajuste no qual às empresas que adotaram entre zero e duas prática atribuiu-se valor zero, considerando que a VD1 não está evidente na sua operação. Já às empresas que assumiram entre três e cinco práticas, atribuiu-se valor um, aceitando-se a presença da VD1 na gestão. Segue a Tabela 20 que apresenta os coeficientes de regressão logística ordinal obtidos, bem como as variáveis preditoras relacionadas a VD1. 
A estatística $\hat{\beta}_{i}$, o p-valor e a estimativa de razão de chances mostram que somente a norma AA 1000 foi estatisticamente relacionada à pluralidade e à participação dos colaboradores na gestão (VD1). Sua presença aumenta em 1,81 a possibilidade de evidenciação da VD1.

Tabela 20 - Coeficientes de regressão logística ordinal para a variável dicotomizada VD1

\begin{tabular}{l|l|l|l|l|l}
\hline Variável & $\mathrm{gl}$ & $\hat{\beta}_{i}$ & Erro padrão & $\mathrm{p}$-valor & Odds \\
\hline AA1000 & 1 & 0.5931 & 0.2687 & 0.0273 & 1.810 \\
\hline PGLOBAL & 1 & 0.4603 & 0.2493 & 0.0649 & 1.585 \\
\hline
\end{tabular}

Acreditava-se que ser signatária dos Princípios do Pacto Global, seguir as Diretrizes da OCDE e possuir normas SA 8000/OHSAS18000/BS8800 também teriam relação significativa com a variável estudada. As duas primeiras, visto que possuem entre os seus compromissos a eliminação da discriminação no emprego, já as normas SA8000/OHSAS18000/BS8800, porque estão diretamente vinculadas à segurança, à saúde e às relações de trabalho.

O teste de Hosmer-Lemeshow que analisa a capacidade preditiva do modelo associando as probabilidades estimadas da mais alta a mais baixa para determinar se as frequências observadas estão próximas das esperadas foi utilizado para complementar a análise. A norma AA 1000 explica 76,8\% da presença da VR1 nas empresas pesquisadas. Portanto, estatisticamente, a hipótese de proporcionalidade da razão de chances ao nível da variável resposta não é negada e o p-valor é 0,8259 , indicando boa qualidade do ajuste.

A VR2, que se refere ao envolvimento com questões da comunidade e de interesse público, pode assumir seis valores, entre 0 e 5, usando 3 como ponto de corte. Segue a Tabela 21 que apresenta as variáveis preditoras relacionadas a VD2.

Tabela 21 - Coeficientes de regressão logística ordinal para a variável dicotomizada VD2

\begin{tabular}{l|l|l|l|l|l}
\hline Variável & $\mathrm{gl}$ & $\hat{\beta}_{i}$ & Erro padrão & $\mathrm{p}$-valor & Odds \\
\hline BSOCIAL & 1 & 0.7825 & 0.2610 & 0.0027 & 2.187 \\
\hline PGLOBAL & 1 & 0.4540 & 0.2662 & 0.0881 & 1.575 \\
\hline ISO14000 & 1 & 0.7122 & 0.3287 & 0.0302 & 2.038 \\
\hline SA_OHSAS & 1 & -0.5825 & 0.3364 & 0.0833 & 0.558 \\
\hline AA1000 & 1 & 0.4137 & 0.3316 & 0.2122 & 1.512 \\
\hline
\end{tabular}

Cinco variáveis preditoras foram associadas à VD2. Entretanto, três delas apresentaram padrão de significância maior que 5\%, sendo excluídas do modelo. As variáveis significativamente relacionadas referem-se à publicação do Balanço Social e à adoção da 
norma ISO 14000. A publicação do Balanço Social aumenta a razão de chances do envolvimento da empresa com questões da comunidade em 2,18 e a norma ISO 14000 em 2,03 .

Utilizando-se do teste de Hosmer-Lemeshow para analisar a qualidade do ajuste e comparando-se as probabilidades preditas com as respostas observadas, pode-se afirmar que as duas variáveis associadas explicam 71,5\% da presença da VR2 nas empresas pesquisadas.

A terceira variável estudada no princípio ecológico diversidade refere-se à inserção da comunidade na rede de negócios (VD3). Esta variável pode assumir cinco valores, entre 0 e 4 , usando dois como ponto de corte. Desta forma, às empresas que adotaram entre zero e uma prática atribuiu-se valor zero, considerando que a VD3 não está evidente na sua operação. Já às empresas que assumiram entre duas e quatro práticas atribuiu-se valor um, aceitando-se a presença da VD3 na gestão. Segue a Tabela 22 que apresenta os coeficientes de regressão logística ordinal obtidos, bem como as variáveis preditoras relacionadas a VD3.

Tabela 22 - Coeficientes de regressão logística ordinal para a variável dicotomizada VD3

\begin{tabular}{l|l|l|l|l|l}
\hline Variável & $\mathrm{gl}$ & $\hat{\beta}_{i}$ & Erro padrão & $\mathrm{p}$-valor & Odds \\
\hline PGLOBAL & 1 & 1.1974 & 0.2610 & $<.0001$ & 3.311 \\
\hline AA1000 & 1 & 0.7886 & 0.3283 & 0.0163 & 2.200 \\
\hline BSOCIAL & 1 & -0.5250 & 0.2615 & 0.0447 & 0.592 \\
\hline
\end{tabular}

As variáveis preditoras que se referem à adoção dos Princípios do Pacto Global, à norma AA 1000, bem como à publicação do Balanço Social, foram identificadas como relacionadas com a inserção da comunidade na rede de negócios (VD3). As duas primeiras tem coeficiente de regressão positivo significando que o aumento da resposta positiva implica num aumento da presença da VD3.

Já o Balanço social possui coeficiente $\hat{\beta}_{i}$ negativo, ou seja, a existência de tal ferramenta de gestão na empresa leva a redução de políticas vinculadas à inclusão de grupos da comunidade ou moradores da região onde a empresa está instalada entre os fornecedores. Tal ferramenta reduz em 59\% a possibilidade da empresa envolver-se com a VD3. Tal fato também já havia sido identificado na VR1 e na VR2. Portanto, parece haver indícios de que empresas que publicam o Balanço Social ainda não possuem uma preocupação com a gestão em rede das práticas socioambientais de modo a vinculá-las a sua cadeia de negócio. É importante realizar 
estudos complementares para compreender que outras qualidades ou atributos podem estar influenciando em tal relação negativa.

Para a VD3 o modelo final resultou em três das sete variáveis preditoras estudadas que em conjunto explicam 77,1\% dos casos analisados. O teste de Hosmer-Lemeshow tem um p-valor de 0,7644 , indicando um bom ajuste para a capacidade preditiva.

A última variável estudada na macrovariável diversidade refere-se ao diálogo e à comunicação com os públicos de relacionamento (VD4). Ela foi avaliada a partir de quatro questões presentes no questionário dos Indicadores Ethos 2008, podendo assumir cinco valores, entre 0 e 4 . Para ajustamento e análise foi utilizado dois como ponto de corte.

A técnica da regressão logística ordinal, conforme dados apresentados na Tabela 23, apontou que quatro ferramentas de gestão apresentaram-se relacionadas à VD4. Três delas possuem uma associação com padrão de significância, sendo: certificação AA 1000, o Balanço Social e o Código de Conduta.

Tabela 23 - Coeficientes de regressão logística ordinal para a variável dicotomizada VD4

\begin{tabular}{l|l|l|l|l|l}
\hline Variável & gl & $\hat{\beta}_{i}$ & Erro padrão & p-valor & Odds \\
\hline BSOCIAL & 1 & 1.4599 & 0.3919 & 0.0002 & 4.306 \\
\hline AA1000 & 1 & 1.6839 & 0.7494 & 0.0246 & 5.386 \\
\hline CONDUTA & 1 & 0.7919 & 0.3805 & 0.0374 & 2.208 \\
\hline ISO14000 & 1 & 0.5768 & 0.3792 & 0.1283 & 1.780 \\
\hline
\end{tabular}

Dentre essas, a AA 1000 foi a variável preditora mais importante, aumentando a razão de chances da presença da VD4 em 5,38. Outra ferramenta de gestão que também apareceu vinculada de maneira relevante ao diálogo e à comunicação com os públicos de relacionamento foi a publicação do Balanço Social, numa proporção de 4,3.

Acreditava-se que a norma AA 1000 manifestar-se-ia no modelo de relacionamento uma vez que o escopo da VD4 está vinculado ao foco da norma. Quanto à publicação do Balanço Social, embora ela apareça negativamente relacionada à gestão em rede das práticas socioambientais, observou-se que está positivamente associada às variáveis que abrangem comunicação e envolvimento com stakeholders (VR4 e VR2). Pode-se inferir, portanto, que a presença de tal ferramenta implica numa seletividade das práticas de gestão adotadas pela empresa. 
O teste de Hosmer-Lemeshow indica que as três variáveis preditoras significativamente associadas explicam 84,4\% da presença da variável resposta VD4 com um p-valor de 0,9603, apresentando uma boa capacidade preditiva.

A partir do Quadro 22, observando as variáveis preditoras em relação à macrovariável diversidade, cabe afirmar que a norma AA 1000 foi a ferramenta de gestão mais relacionada às dimensões estudadas. Tal ferramenta está presente nas quatro dimensões, embora para uma delas apareça como não significativa. Pode-se dizer que a AA 1000 quando presente na empresa potencializa a interação, a comunicação e o relacionamento da mesma junto aos diferentes públicos.

Quadro 22 - Presença das variáveis preditoras relativas à macrovariável diversidade, com indicação do sinal da estimativa, ou não-significância.

\begin{tabular}{|c|c|c|c|c|}
\hline \multirow{2}{*}{ Variável Preditora } & \multicolumn{4}{|c|}{ Variável Resposta (presença no modelo) } \\
\hline & VD1 & VD2 & VD3 & VD4 \\
\hline PGLOBAL & Não significativo & Não significativo & $\underset{p \leq 0,01}{\text { Sim, }}$ & \\
\hline \multicolumn{5}{|l|}{ OCDE } \\
\hline CONDUTA & & & & $\underset{p \leq 0,05}{\text { Sim, }}$ \\
\hline BSOCIAL & & $\underset{p \leq 0,01}{\text { Sim, }}$ & $\begin{array}{c}\text { Sim, } \\
\text { negativo } p \leq 0,05\end{array}$ & $\underset{p \leq 0,01}{\text { Sim, }}$ \\
\hline SA-OHSAS & & Não significativo & & \\
\hline AA1000 & $\begin{array}{c}\text { Sim, } \\
\mathrm{p} \leq 0,05\end{array}$ & Não significativo & Sim, $\mathrm{p} \leq 0,05$ & $\begin{array}{c}\text { Sim, } \\
\mathrm{p} \leq 0,05\end{array}$ \\
\hline ISO14000 & & $\begin{array}{c}\text { Sim, } \\
\mathrm{p} \leq 0,05\end{array}$ & & Não significativo \\
\hline
\end{tabular}

Outra ferramenta de gestão que também apresentou relacionamento significativo em três das quatro dimensões analisadas foi a publicação do Balanço Social, embora com associação negativa em uma das dimensões analisadas.

\subsubsection{Macrovariável Equilíbrio Dinâmico}

O Equilíbrio Dinâmico foi a última macrovariável analisada, sendo formado por três variáveis de análise: VE1- Mecanismos de avaliação e monitoramento das relações com diferentes públicos de relacionamento; VE2- Avaliação do desempenho social; VE3- Avaliação do desempenho ambiental. 
A existência de mecanismos de avaliação e monitoramento das relações com diferentes públicos de relacionamento denominada de VE1 é formada por três questões advindas do questionário de Indicadores Ethos 2008, podendo assumir quatro valores entre 0 e 3 . O ajuste realizado para a aplicação da técnica da regressão logística considerou o valor dois como ponto de corte. Portanto, às empresas que adotaram entre zero e uma prática atribuiu-se valor zero, considerando que a VE1 não está evidente nas suas operações. Atribuiu-se valor um, aceitando-se a presença da VE1 na gestão, quando a empresa adotou duas ou três práticas. Segue a Tabela 24 que apresenta os coeficientes de regressão logística ordinal obtidos, bem como as variáveis preditoras relacionadas a VE1.

Tabela 24 - Coeficientes de regressão logística ordinal para a variável dicotomizada VE1

\begin{tabular}{l|l|l|l|l|l}
\hline Variável & $\mathrm{gl}$ & $\hat{\beta}_{i}$ & Erro padrão & $\mathrm{p}$-valor & Odds \\
\hline ISO14000 & 1 & 1.0635 & 0.2775 & 0.0001 & 2.897 \\
\hline PGLOBAL & 1 & 0.6571 & 0.2692 & 0.0147 & 1.929 \\
\hline BSOCIAL & 1 & 0.5777 & 0.2626 & 0.0278 & 1.782 \\
\hline CONDUTA & 1 & 0.6620 & 0.3337 & 0.0473 & 1.939 \\
\hline
\end{tabular}

Considerando os coeficientes de regressão, observou-se que quatro ferramentas de gestão estão vinculadas à existência de mecanismos de avaliação e monitoramento das relações com diferentes públicos de relacionamento, sendo elas: possuir a norma ISO 14000, ser signatária do Pacto Global, publicar o Balanço Social e possuir um Código de Conduta. Destaca-se que entre estas ferramentas, a norma ISO 14000 foi a variável preditora mais importante, aumentando a razão de chances da presença da VE1 em 2,9, em relação ao nível zero. Talvez isso ocorra porque a sua adoção exige o acompanhamento do desempenho de sua cadeia de fornecimento no que se refere a impactos ambientais.

Acreditava-se que a norma AA 1000 apareceria como relevante para esta variável uma vez que seu escopo está direcionado para disponibilizar informações às partes interessadas sobre o desempenho de uma organização em matéria de sustentabilidade. Entretanto, tal relação não foi identificada, abrindo espaço para a realização de estudos complementares envolvendo outros aspectos e práticas de âmbito organizacional interno.

O teste de Hosmer-Lemeshow, que analisa a capacidade preditiva do modelo associando às probabilidades estimadas da mais alta à mais baixa para determinar se as frequências observadas estão próximas das esperadas, foi utilizado para complementar a análise. Em 
conjunto, as quatro variáveis preditoras relacionadas explicam $77 \%$ da presença da VE1 nas empresas pesquisadas. Portanto, estatisticamente, a hipótese de proporcionalidade da razão de chances ao nível da variável resposta não é negada e o p-valor é 0,7902 , indicando boa qualidade do ajuste.

As variáveis VE2 e VE3 propõem conhecer a existência de indicadores de avaliação dos desempenhos social e ambiental. Estas variáveis respostas possuem particularidades por não serem obtidas a partir da soma de variáveis dicotômicas. Conforme já relatado no item 4.1.2.4 desta tese, é importante destacar novamente que a não-resposta de todos os itens destes constructos foi a alternativa mais recorrente.

A VE2 é formada por sete questões presentes no questionário de Indicadores Ethos 2008, podendo assumir valores entre -7 e 12. Para tratamento via regressão logística da VE2, utilizou-se a seguinte categorização: atribuiu-se o valor 0 quando VE2 é menor que 3, e valor 1 quando é pelo menos 3 , definindo uma variável dicotômica. O ponto de corte foi dado pela mediana dos valores.

A Tabela 25 indica coeficientes de regressão significativos para as variáveis preditoras normas SA8000/OHSAS18000/BS8800 e norma AA 1000. Portanto, a presença destas duas ferramentas de gestão nas empresas estudadas apresentou influência sobre a VE2.

Tabela 25 - Coeficientes de regressão logística ordinal para a variável dicotomizada VE2

\begin{tabular}{l|l|l|l|l|l}
\hline Variável & gl & $\hat{\beta}_{i}$ & Erro padrão & p-valor & Odds \\
\hline SA-OHSAS & 1 & -0.8520 & 0.3029 & 0.0049 & 0.427 \\
\hline AA1000 & 1 & 0.5413 & 0.2748 & 0.0488 & 1.718 \\
\hline ISO14000 & 1 & -0.4820 & 0.2825 & 0.0880 & 0.618 \\
\hline
\end{tabular}

Destaca-se que as normas SA8000/OHSAS18000/BS8800 possuem associação negativa. Isto é, comparando a presença e ausência das normas SA8000/OHSAS18001/BS8800 entre as empresas estudadas, observa-se que sua presença reduz em 42,7\% a probabilidade das mesmas preocuparem-se com o seu desempenho social. Tal fato merece a realização de estudos posteriores para uma análise mais aprofundada uma vez que essas normas buscam melhorar a saúde, a segurança e a qualidade de vida no trabalho, aspectos estes diretamente vinculados ao desempenho social. Observa-se que as normas SA8000/OHSAS18000/BS8800 também apresentaram uma relação negativa com a VC3. 
Comparando as probabilidades preditas com as respostas observadas e buscando analisar a qualidade do ajuste realizado, foi utilizado o teste de Hosmer-Lemeshow. Em conjunto, as variáveis preditoras normas SA8000/OHSAS18000/BS8800 e norma AA 1000 explicam $76,6 \%$ da presença da VE2 nas empresas estudadas. O teste tem um p-valor é 0.5682 , indicando um bom ajuste.

A VE3 que se refere ao relato do desempenho ambiental da empresa foi a última variável estudada na macrovariável equilíbrio dinâmico. Esta variável é formada por cinco questões do questionário de Indicadores Ethos, assumindo valores entre -5 e 10. A mediana dos valores foi utilizada como ponto de corte. Portanto, atribuiu-se valor zero quando VE3 é menor que três, e valor um quando é pelo menos três, definindo uma variável dicotômica.

A estatística $\hat{\beta}_{i}$ indica o impacto da desigualdade $\mathrm{e}^{\mathrm{z}}$ de uma variação em uma das variáveis, mantendo as demais constantes. Observa-se, a partir da tabela 26, um alto coeficiente de regressão para a variável preditora SA8000/OHSAS18000/BS8800. Esta variável apresentou associação negativa com a VE3, reduzindo em 49,8\% a probabilidade das empresas relatarem seu desempenho ambiental. Inferência similar foi encontrada na análise da VE2.

Tabela 26 - Coeficientes de regressão logística ordinal para a variável dicotomizada VE3

\begin{tabular}{l|l|l|l|l|l}
\hline Variável & Gl & $\hat{\beta}_{i}$ & Erro padrão & p-valor & Odds \\
\hline SA-OHSAS & 1 & -0.6966 & 0.2698 & 0.0098 & 0.498 \\
\hline PGLOBAL & 1 & -0.4676 & 0.2521 & 0.0636 & 0.627 \\
\hline
\end{tabular}

As demais ferramentas de gestão não foram significativas para a mensuração do desempenho ambiental (VE3). Acreditava-se que a norma ISO 14000 apareceria com significativa associação no modelo devido ao escopo e propósito da norma, entretanto tal fato não foi identificado a partir das análises de regressão logística realizadas. Utilizando-se o teste de Hosmer-Lemeshow para comparar as probabilidades preditas com as respostas observadas, identificou-se um percentual de concordância do modelo de 73,9\% e um p-valor de 0.5033 . 
Quadro 23 - Presença das variáveis preditoras relativas à macrovariável equilíbrio dinâmico, com indicação do sinal da estimativa, ou não-significância.

\begin{tabular}{|c|c|c|c|}
\hline \multirow{2}{*}{ Variável Preditora } & \multicolumn{3}{|c|}{ Variável Resposta (presença no modelo) } \\
\cline { 2 - 4 } & VE1 & VE2 & VE3 \\
\hline PGLOBAL & Sim, $\mathrm{p} \leq 0,05$ & & \\
\hline OCDE & & & \\
\hline CONDUTA & Sim, $\mathrm{p} \leq 0,05$ & & \\
\hline BSOCIAL & Sim, $\mathrm{p} \leq 0,05$ & & Sim, negaticativo $\mathrm{p} \leq 0,01$ \\
\hline SA-OHSAS & & Sim, negativo $\mathrm{p} \leq 0,01$ & \\
\hline AA1000 & & Sim, $\mathrm{p} \leq 0,05$ & \\
\hline ISO14000 & Sim, $\mathrm{p} \leq 0,01$ & Não significativo & \\
\hline
\end{tabular}

Numa análise global das variáveis preditoras em relação à macrovariável equilíbrio dinâmico, conforme destacado no Quadro 23, pode-se afirmar que nenhuma ferramenta de gestão foi significativa para as três dimensões analisadas. Todavia as normas SA8000/OHSAS18000/BS8800 apresentaram importante associação negativa em duas das três dimensões estudadas. Portanto, há relevante indício de que a sua presença inibe o envolvimento das empresas estudadas com a mensuração do seu desempenho social e ambiental.

\subsection{Análise das Hipóteses de Pesquisa}

As hipóteses que orientam a pesquisa buscam identificar se as variáveis preditoras estão associadas positivamente com as variáveis resposta. Para esta análise, foram utilizados os resultados agrupados obtidos a partir da técnica da regressão logística. As considerações serão apresentadas para cada uma das hipóteses.

\subsubsection{Hipótese 1}

A primeira hipótese foi assim enunciada: A existência de ferramentas de gestão para a sustentabilidade está positivamente associada à presença de princípios ecológicos nas empresas. O Quadro 24 apresenta os resultados agregados na forma de frequência e as correlações positivas entre as variáveis em estudo com nível de significância de $5 \%$. 
Quadro 24 - Frequência das correlações positivas entre as variáveis em estudo

\begin{tabular}{|c|c|c|c|c|c|c|}
\hline \multirow{2}{*}{$\begin{array}{l}\text { Variável } \\
\text { Resposta } \\
\text { Variável } \\
\text { Preditora }\end{array}$} & \multicolumn{4}{|c|}{ Correlações $(p \leq 0,05)$} & \multirow{2}{*}{\multicolumn{2}{|c|}{$\begin{array}{c}\text { Total de } \\
\text { Correlações } \\
\text { Obtidas }\end{array}$}} \\
\hline & $\begin{array}{c}\text { CICLO } \\
\text { (3 variáveis) }\end{array}$ & $\begin{array}{c}\text { REDE } \\
\text { (3 variáveis) }\end{array}$ & $\begin{array}{l}\text { DIVERSIDADE } \\
\text { (4 variáveis) }\end{array}$ & $\begin{array}{c}\text { EQUILÍBRIO } \\
\text { DINÂMICO } \\
\text { (3 variáveis) }\end{array}$ & & \\
\hline PGLOBAL & & 02 & 01 & 01 & 04 & 28,57 \\
\hline OCDE & & 01 & & & 01 & 7,69 \\
\hline CONDUTA & 03 & 01 & 01 & 01 & 06 & 46,15 \\
\hline BSOCIAL & 01 & & 02 & 01 & 04 & 28,57 \\
\hline SA-OHSAS & & 02 & & & $\mathbf{0 2}$ & 15,38 \\
\hline AA1000 & & 03 & 03 & 01 & $\mathbf{0 7}$ & 53,84 \\
\hline ISO14000 & 03 & & 01 & 01 & 05 & 38,46 \\
\hline
\end{tabular}

Observou-se que algumas ferramentas de gestão (variáveis preditoras) possuem associação estatisticamente significativa com os princípios ecológicos estudados (variáveis resposta). Sendo que algumas ferramentas de gestão possuem um maior número de associações do que outras em relação aos princípios ecológicos.

Numa análise geral é possível concluir que as três ferramentas de gestão mais positivamente relacionadas aos princípios ecológicos foram a norma AA 1000 com sete correlações significativas, seguida pelo Código de Conduta com seis relações significativas e pela ISO 14000 com cinco relações significativas. Destaca-se que estas mesmas três normas também foram as únicas que apresentaram correlação estatisticamente válida em todas as dimensões estudadas de alguns dos princípios ecológicos, sendo:

a) O Código de Conduta apresentou relação importante com o princípio ecológico Ciclo. Foram identificadas correlação positiva com as três variáveis estudadas: VC1- Redução do impacto ambiental nos processos internos $(\mathrm{p} \leq 0,01) ; \mathrm{VC} 2$ - Concepção ecológica do produto e destinação pós-consumo $(\mathrm{p} \leq 0,05)$ e VC3 - Ecoeficiência $(\mathrm{p} \leq 0,05)$.

b) A norma ISO 14000 também possui correlação positiva com todas as variáveis, que compreendem o princípio ecológico ciclo, sendo que nas três dimensões foram identificados níveis de significância menor ou igual a $1(\mathrm{p} \leq 0,01)$.

c) A norma AA 1000 apresentou relação importante com o princípio ecológico Rede e constatou-se correlação com as três variáveis estudadas: VR1 - Existência de programa de responsabilidade socioambiental para a cadeia de fornecedores $(\mathrm{p} \leq 0,01)$; VR2 Adoção de critérios socioambientais para compras $(\mathrm{p} \leq 0,05)$ e VR3 - Monitoramento das posturas socioambientais de fornecedores $(\mathrm{p} \leq 0,05)$.

Acredita-se, portanto, que estas normas são mais efetivas na indução da adoção de práticas socioambientais vinculadas a estes princípios ecológicos. A partir do Quadro 24 é possível 
percebe-se que há uma maior quantidade de normas vinculadas ao princípio ecológico rede e diversidade, com ligações mais fortes, do que para os princípios ecológicos ciclo e equilíbrio dinâmico. Observa-se também que o Código de Conduta é a única ferramenta de gestão que possui pelos menos uma associação significativa com todos os princípios ecológicos estudados, estando parcialmente relacionado a todos eles.

Entretanto, em parte das relações encontradas, identificou-se correlações negativas com significância estatística $(\mathrm{p} \leq 0,05)$ entre as variáveis estudadas, conforme disposto no Quadro 25. Isto é, a presença da ferramenta de gestão na empresa reduz a evidência do princípio ecológico.

Quadro 25 - Frequência das correlações negativas entre as variáveis em estudo

\begin{tabular}{|c|c|c|c|c|c|c|}
\hline \multirow{2}{*}{$\begin{array}{l}\text { Variável } \\
\text { Resposta } \\
\text { Variável } \\
\text { Preditora }\end{array}$} & \multicolumn{4}{|c|}{ Correlações $(p \leq \mathbf{0 , 0 5})$} & \multirow{2}{*}{\multicolumn{2}{|c|}{$\begin{array}{l}\text { Total de } \\
\text { Correlações } \\
\text { Obtidas }\end{array}$}} \\
\hline & \multirow[t]{2}{*}{$\begin{array}{c}\text { CICLO } \\
\text { (3 variáveis) }\end{array}$} & \multirow[t]{2}{*}{$\begin{array}{c}\text { REDE } \\
\text { (3 variáveis) }\end{array}$} & \multirow[t]{2}{*}{$\begin{array}{c}\text { DIVERSIDADE } \\
\text { (4 variáveis) }\end{array}$} & $\begin{array}{l}\text { EQUILÍBRIO } \\
\text { DINÂMICO } \\
\text { (3 variáveis) } \\
\end{array}$ & & \\
\hline & & & & & & \\
\hline OCDE & & 01 & & & 01 & 7,69 \\
\hline CONDUTA & & & & & & \\
\hline BSOCIAL & & 02 & 01 & & 03 & 23,07 \\
\hline SA-OHSAS & 01 & & & 02 & 03 & 23,07 \\
\hline AA1000 & & & & & & \\
\hline ISO14000 & & & & & & \\
\hline
\end{tabular}

Três ferramentas de gestão apresentam relação negativa em algumas dimensões dos princípios ecológicos, sendo que o Balanço Social e as normas SA8000/OHSAS18000/BS8800 são as mais significativas. A partir destes resultados é possível observar que:

a) Das cinco correlações estatisticamente significativas encontradas entre as normas SA8000/OHSAS18000/BS8800 e os princípios ecológicos, três delas possuem associações negativas, sendo: VC3 - Ecoeficiência $(\mathrm{p} \leq 0,05)$, VE2- Avaliação do desempenho social $(\mathrm{p} \leq 0,01)$ e VE3- Avaliação do desempenho ambiental $(\mathrm{p} \leq 0,01)$.

b) Já o Balanço Social, de um total de sete associações estatisticamente significativas, três delas envolvem correlações negativas, sendo: VR1 - Existência de programa de responsabilidade socioambiental para a cadeia de fornecedores $(p \leq 0,05)$, VR2 Adoção de critérios socioambientais para compras $(\mathrm{p} \leq 0,01)$ e VD3 - Inserção da comunidade na rede de negócios $(\mathrm{p} \leq 0,05)$.

c) Os Princípios da OCDE apresentaram apenas duas correlações estatisticamente significativas e uma delas com correlação negativa - VR2 - Adoção de critérios socioambientais para compras $(\mathrm{p} \leq 0,05)$. 
Determinadas associações negativas encontradas levam a novas perguntas de pesquisa de natureza explicativa: Por que as normas SA8000/OHSAS18000/BS8800 reduzem o comprometimento da empresa com mecanismos de monitoramento do seu desempenho socioambiental? Por que a publicação do balanço social induz a uma menor atenção da empresa a políticas socioambientais de sua rede de negócios? Por que a adoção dos Princípios da OCDE implica num baixo envolvimento com critérios socioambientais para compras se as multinacionais possuem maior necessidade de legitimar a conduta de sua cadeia de negócios? Dessa forma, sugere-se a realização de estudos futuros complementares envolvendo outros aspectos de modo a conhecer possíveis elementos influentes em tal relação encontrada.

Portanto, a $\mathrm{H}_{1}$ foi parcialmente confirmada uma vez que além das associações positiva também foram observadas correlações negativas entre as variáveis preditoras e resposta.

\subsubsection{Hipótese 2}

A segunda hipótese foi assim enunciada: Quanto maior o número de ferramentas de gestão para a sustentabilidade presentes nas empresas, maior a evidência dos princípios ecológicos nas mesmas. A análise dos dados obtidos através da técnica de regressão logística também não confirmou a segunda hipótese uma vez que as ferramentas de gestão apresentam relações diferenciadas com os princípios ecológicos.

Pode-se dizer que algumas ferramentas de gestão são mais efetivas do que outras. A maior evidência de princípios ecológicos dependerá de qual dessas ferramentas foi assimilada pela empresa. Caso a empresa possua ferramentas de gestão que apresentem correlação positiva, a exemplo das normas SA8000/OHSAS18000/BS8800 e do Balanço Social, menor será a evidência dos princípios ecológicos na empresa.

A análise dos dados possibilitou identificar que as ferramentas mais efetivas são a norma AA 1000, adotada em conjunto com a norma ISO 14000. Conforme disposto no Quadro 26, podese perceber que ambas se complementam e quando assimiladas de maneira agregada são significativas para 13 das 14 variáveis resposta analisadas. 
Quadro 26 - Correlações positivas entre as variáveis AA 1000 e ISO 14000 e os princípios ecológicos

\begin{tabular}{|c|c|c|c|c|c|c|c|c|c|c|c|c|c|}
\hline \multirow{3}{*}{ Variável Preditora } & \multicolumn{13}{|c|}{ Correlações } \\
\hline & \multicolumn{3}{|c|}{ CICLO } & \multicolumn{3}{|c|}{ REDE } & \multicolumn{4}{|c|}{ DIVERSIDADE } & \multicolumn{3}{|c|}{$\begin{array}{l}\text { EQUILÍBRIO } \\
\text { DINÂMICO }\end{array}$} \\
\hline & VC1 & $\mathrm{VC2}$ & VC3 & VR1 & VR2 & VR3 & VD1 & VD2 & VD3 & VD4 & VE1 & VE2 & VE3 \\
\hline AA1000 & & & & $\begin{array}{c}\mathrm{p} \leq \\
0,01\end{array}$ & $\begin{array}{c}\mathrm{p} \leq \\
0,05\end{array}$ & $\begin{array}{c}\mathrm{p} \leq \\
0,05\end{array}$ & $\begin{array}{c}\mathrm{p} \leq \\
0,05\end{array}$ & & $\begin{array}{c}\mathrm{p} \leq \\
0,05\end{array}$ & $\begin{array}{c}\mathrm{p} \leq \\
0,05\end{array}$ & & $\begin{array}{c}\mathrm{p} \leq \\
0,05\end{array}$ & \\
\hline ISO14000 & $\begin{array}{c}\mathrm{p} \leq \\
0,01\end{array}$ & $\begin{array}{c}\mathrm{p} \leq \\
0,01\end{array}$ & $\begin{array}{c}\mathrm{p} \leq \\
0,01\end{array}$ & & & & & $\begin{array}{c}\mathrm{p} \leq \\
0,05\end{array}$ & & & $\begin{array}{c}\mathrm{p} \leq \\
0,01\end{array}$ & & \\
\hline
\end{tabular}

\subsubsection{Hipótese 3}

A terceira hipótese foi assim enunciada: Diferentes ferramentas de gestão para a sustentabilidade levam a assimilação de diferentes características ecológicas pelas empresas. O Quadro 24 possibilitou observar que diferentes ferramentas de gestão estão vinculadas a diferentes princípios ecológicos, confirmando a $\mathrm{H}_{3}$. Por exemplo: a existência do Código de Conduta e a norma ISO 14000 estão mais vinculadas ao princípio ecológico ciclo. Já a norma AA 1000 está mais relacionada ao princípio ecológico rede e diversidade. A publicação do Balanço Social também está mais associada à diversidade do que aos outros princípios ecológicos. Ser signatário dos princípios do Pacto Global cria maior vínculo da empresa com a variável rede, assim como as normas SA8000/OHSAS18000/BS8800. Por outro lado, os Princípios da OCDE não apresentam vínculo substancial com nenhum dos princípios ecológicos estudados. A Figura 11 traz uma síntese da intensidade das relações encontradas entre as variáveis. 


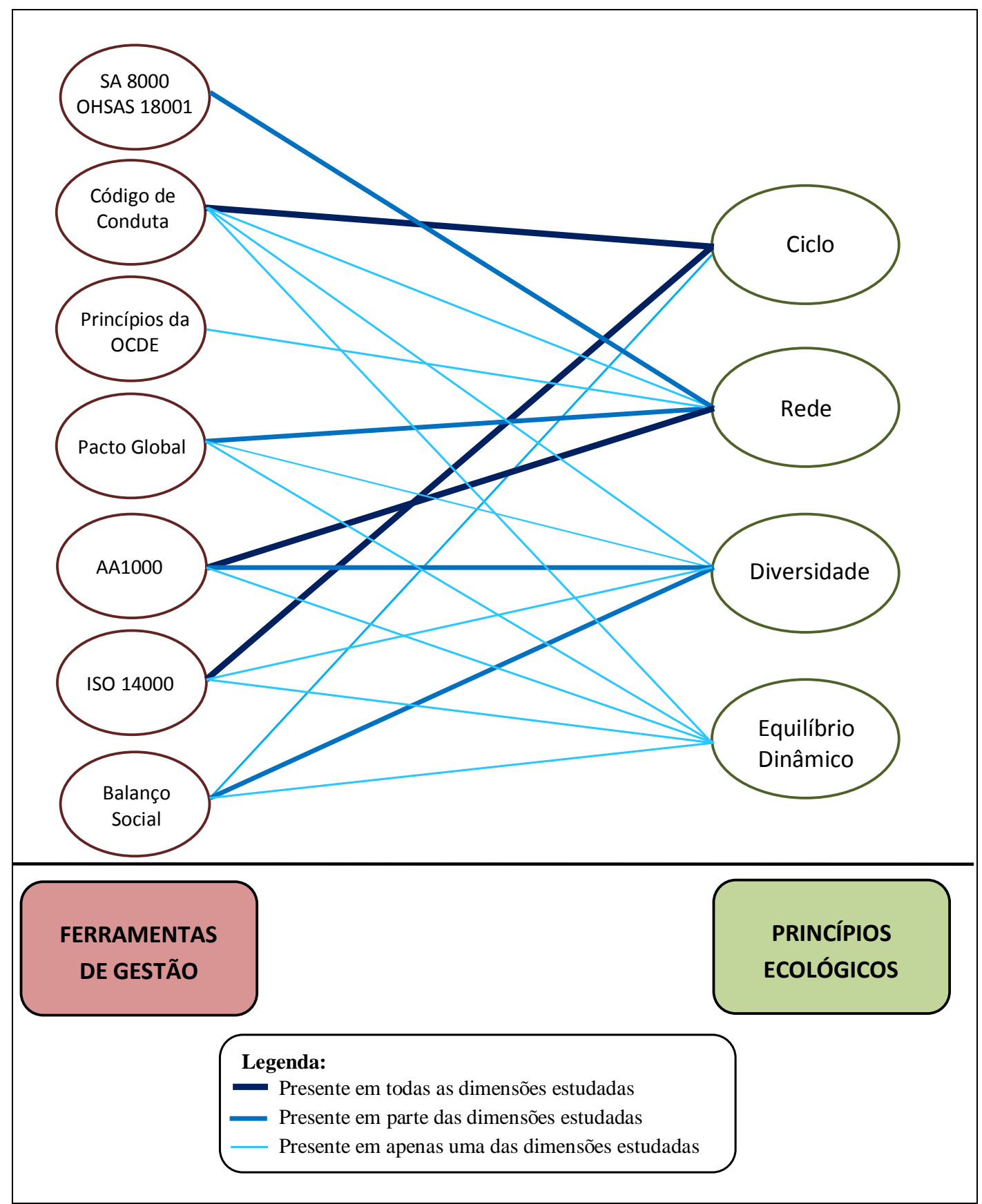

Figura 11 - Intensidade das relações encontradas entre as ferramentas de gestão e os princípios ecológicos

Foi possível perceber que a adoção dos Princípios da OCDE e das normas SA8000/OHSAS18000/BS8800 foram as ferramentas menos associadas aos princípios ecológicos estudados. Pode-se inferir que tais ferramentas vêm contribuindo pouco para que as empresas adotem um padrão de estruturação de suas práticas socioambientais alicerçadas nos princípios ecológicos. A efetividade de tais ferramentas pode ser questionada quanto a sua contribuição para a gestão sustentável da empresa. 
Destaca-se ainda que entre as cinco ferramentas positivamente associadas ao princípio equilíbrio dinâmico, nenhuma delas apresentou-se estatisticamente relacionada a mais de uma categoria de análise. Supõe-se que as ferramentas de gestão estudadas não estão potencializando suficientemente a adoção da avaliação e do monitoramento das relações com os diferentes públicos de relacionamento. Talvez isto explique o baixo envolvimento das empresas com esta macrovariável, conforme apresentado no item 4.2.4. 


\section{CONSIDERAÇÕES FINAIS}

A literatura em administração é abundante em recomendar modelos e instrumentos de gestão para estruturar empresas mais sustentáveis. Não existe, porém, unanimidade em relação ao escopo e as linhas de pensamento.

A própria indefinição sobre como atingir o desenvolvimento sustentável acaba por dificultar a demarcação do modo de gestão. As variadas definições para o termo sustentabilidade - assim como dos conceitos de liberdade, democracia e igualdade - carregam consigo diferentes percepções de interpretações do mundo e múltiplos critérios de racionalidade. Sendo, portanto, mutáveis ao longo do tempo e contestáveis.

A percepção sobre o que define um negócio como sustentável também sofreu alterações. $\mathrm{Na}$ contemporaneidade, entre os teóricos da administração, o entendimento da gestão sustentável da empresa vem sendo mais vinculado a estruturas e práticas para respostas às necessidades e aspirações dos diferentes públicos de relacionamento (stakeholders), bem como ao desempenho embasado no tríplice resultado (triple bottom line) - econômico, ambiental e social.

Contudo, as premissas para a compreensão da gestão sustentável ainda estão restritas ao comportamento do homem para o homem e do homem para a sociedade, numa perspectiva antropocêntrica. Os modelos organizacionais, como o The Natural Step e a Metodologia Zeri, que compreendem a gestão sustentável, intrinsecamente vinculada às qualidades sistêmicas presentes no mundo natural, ainda estão restritas a um número reduzido de teóricos e empresas, encontrando-se num estágio de aperfeiçoamento.

Ao contrário do que postula o pensamento fragmentado, é importante lembrar que o senso de integração das instituições sociais com o meio ambiente leva a uma característica conhecida em sistemas complexos que é a tendência de formar estruturas que se relacionam. Para se manterem vivas, as empresas precisam acoplar-se estruturalmente com o meio. Tal conexão também implica em pensar nas qualidades que surgem dos processos e padrões ordenados de relações entre as partes, que não podem ser mensuradas, mas sim mapeadas. Portanto, compreender a interdependência ecológica significa entender as relações. 
Nesta tese, utilizando-se das ideias disseminadas pela economia ecológica, bem como da proposição de Capra (1997, 2002, 2006), Müller (2007) e Odum e Barrett (2008), partiu-se da premissa de que as empresas só poderão desenvolve-se de forma sustentável quando o sistema econômico, ao invés de destruir a vida, passar a apoiá-la. Acredita-se, dessa forma, na necessidade de articulação entre as ciências sociais e naturais com respostas integradas e interligadas a diferentes áreas de conhecimento.

O estudo realizado teve como objetivo identificar e analisar as relações entre as ferramentas de gestão para a sustentabilidade e a adoção dos princípios ecológicos pelas empresas. Assim, não houve a intenção de afirmar se uma ferramenta de gestão induz mais facilmente à sustentabilidade do negócio, mas avaliar se a presença delas está direcionando a um padrão de comportamento empresarial consistente com os princípios de organização dos ecossistemas.

A revisão da bibliografia envolveu o tema desenvolvimento sustentável e suas diferentes perspectivas teóricas, destacando-se a proposição dos princípios ecológicos para estruturar sociedades humanas sustentáveis. Também foram apresentados os principais entendimentos sobre a responsabilidade socioambiental e a sustentabilidade da empresa elencando algumas ferramentas de gestão mais adotadas no contexto empresarial. Tais discussões foram utilizadas para fundamentar o modelo conceitual teórico desenvolvido nessa tese e apresentado na metodologia.

Um total de 57 questões dispostas no questionário dos Indicadores Ethos foi utilizado, de forma rearranjada, como instrumento de pesquisa. O estudo envolveu 331 empresas pertencentes ao banco de dados dos Indicadores Ethos do ano de 2008 que apresentavam dados completos. Tal opção estratificou qualitativamente os casos em análise, conforme descrito no item 3.2 da Metodologia.

As variáveis estudadas foram compostas por sete ferramentas de gestão, denominadas de variáveis preditoras e quatro princípios ecológicos, chamados de variáveis resposta. A técnica da regressão logística ordinal foi utilizada para verificar as correlações existentes.

A análise das práticas de gestão empreendidas pelas empresas pesquisadas visando compreender a assimilação dos princípios ecológicos apontou que as mesmas estão mais 
envolvidas com ações que abarcam o princípio ecológico da diversidade. Esta característica está vinculada à estrutura de rede das empresas, compreendendo maior complexidade nas conexões com os públicos de relacionamento, o que está em consonância com a teoria dos stakeholders.

Por outro lado, as práticas vinculadas ao monitoramento das ações realizadas foram as menos adotadas pelas empresas, apontando baixa adesão ao princípio ecológico do equilíbrio dinâmico. A falta de mediação, segundo Giovannini e Kruglianskas (2004), pode comprometer os processos de auto-organização e a adaptabilidade, uma das características intrínsecas dos sistemas vivos, dificultando a aprendizagem e a mudança de comportamento.

Utilizando-se da classificação de Barbieri e Cajazeira (2009), que distinguem as ferramentas de gestão em dois grande grupos - princípios diretivos e instrumentos administrativos -, observou-se que aquelas vinculadas a princípios (Adoção do Pacto Global e das Diretrizes da OCDE) encontram-se entre as mais adotadas pelas empresas, estando presentes em mais de $60 \%$ delas. Entretanto, tais ferramentas apresentaram um número pequeno de correlações com os princípios ecológicos estudados. Pode-se dizer que essas ferramentas vêm contribuindo pouco para que as empresas assumam uma estruturação interna coerente com os padrões básicos de organização da vida.

Já para ferramentas de gestão denominadas de instrumentos administrativos foram evidenciados maior número de correlações positivas com os princípios ecológicos. Entre elas, as normas AA1000 e ISO 14000, quando adotadas em conjunto, foram as que apresentaram maior integração com os princípios ecológicos, indicando complementaridade entre ambas. Tal fato pode ter corrido porque tais ferramentas abordam em seu escopo aspectos suplementares. Entretanto, essas mesmas normas estão entre as ferramentas de gestão menos utilizadas pelas empresas. Portanto, sugere-se que organizações não-governamentais, instituições de ensino e pesquisa, bem como entidades vinculadas a setores empresariais realizem estudos para compreender as interseções presentes entre essas normas e fomentem a disseminação das mesmas entre as corporações.

De modo geral, os resultados indicam que as empresas deveriam alterar as ferramentas de gestão até então priorizadas, envolvendo-se com instrumentos que possibilitam uma estruturação organizacional mais efetiva às características básicas presentes nos ecossistemas. 
Um fato interessante percebido ocorreu na análise das normas vinculadas a segurança, saúde e relações de trabalho (normas SA 8000, OHSAS 18001, BS 8800). Essas normas, além de pouco adotada pelas empresas pesquisadas, quase não se apresentaram positivamente vinculadas aos princípios ecológicos. Ao contrário, para as normas SA 8000, OHSAS 18001, BS 8800 e o Balanço Social, foram identificados correlações negativas em relação aos princípios ecológicos em mais de uma categoria de análise. Tal fato aponta para a necessidade de pesquisas futuras objetivando compreender melhor a ocorrência dessas relações.

Os resultados indicaram uma confirmação parcial das hipóteses orientadoras da pesquisa, que tiveram o papel de direcionar o raciocínio da pesquisadora, destacando-se que:

a) A primeira hipótese orientadora foi parcialmente confirmada. Identificou-se que todas as ferramentas de gestão estudadas apresentaram pelo menos uma correlação positiva com os princípios ecológicos analisados (Quadro 24). Entretanto, em três das sete ferramentas analisadas - Balanço Social, normas SA8000/OHSAS 18001 e BS 8800 e Princípios da OCDE - foram encontradas correlações negativas com os princípios ecológicos (Quadro 25). Portanto, não se pode dizer que as ferramentas de gestão para a sustentabilidade encontram-se apenas positivamente relacionadas aos princípios ecológicos.

b) A segunda hipótese orientadora que buscava identificar se um maior número de ferramentas de gestão presentes nas empresas implicava em maior evidência dos princípios ecológicos não foi confirmada. A análise dos dados identificou que algumas ferramentas de gestão evidenciaram um maior número de associações positivas com significância estatística do que outras, podendo ser caracterizadas como de maior interação com os princípios ecológicos. Além disso, conforme já destacado, também foram encontradas correlações negativas. Desta forma, pode-se dizer que o tipo de ferramenta de gestão adotada, ao invés da quantidade, é que impacta diretamente na evidência dos princípios ecológicos.

c) A terceira hipótese de pesquisa, que buscava identificar se diferentes ferramentas de gestão para a sustentabilidade levam à assimilação de diferentes características ecológicas pelas empresas, foi confirmada. Percebeu-se que as ferramentas de gestão, por possuírem características e escopo variados, estão positivamente relacionadas a princípios ecológicos distintos. Também identificou-se variação na força do vínculo entre as variáveis em estudo (Figura 11). 
Numa análise individual das pesquisadas, em alguns casos, parece que as respostas dadas pelas empresas para as questões analisadas apresentaram incongruência entre si. Desta forma, propõe-se que o Instituto Ethos acompanhe as informações prestadas solicitando documentos comprobatórios às respondentes. Tal procedimento possibilitará melhor qualidade e confiabilidade aos dados.

Há necessidade de continuar os estudos e ao longo da análise dos resultados foram apontadas pesquisas para aprofundar o entendimento sobre diferentes efeitos observados entre as variáveis. Como sugestão para pesquisas futuras complementares a essa propõe-se ainda um estudo que analise a relação da norma ISO 26000, lançada em novembro de 2010, com a adoção dos princípios ecológicos pelas empresas. A importância de um estudo de correlação envolvendo essa ferramenta de gestão se dá uma vez que a norma ISO 26000, desenvolvida num processo de construção coletiva do conhecimento, é vista como uma das mais importantes iniciativas internacionais no campo das normas de conduta em responsabilidade socioambiental e definiu um documento técnico global que possui caráter de sistema de gestão. Outro estudo interessante e complementar a essa pesquisa envolve analisar se a adoção dos princípios ecológicos pelas empresas vem reduzindo a pegada ecológica da mesma, isto é, se a aplicação de uma estrutura de gestão condizente com as características presentes nos ecossistemas leva a uma redução no uso da área bioprodutiva do planeta.

Finaliza-se realçando que o estudo objetivou ampliar o entendimento sobre a natureza complexa das relações organizacionais e o desempenho das empresas sob a ótica da sustentabilidade envolvendo a interação com os sistemas naturais. Apresenta-se, portanto, uma visão tridimensional de gestão, na qual o raciocínio de mercado deve compreender as demandas sociais advindas dos stakeholders e a racionalidade ecológica, abarcando propriedades de organização dos ecossistemas. Para tanto, há necessidade de partilhar novos projetos de sociedade, o que não consiste apenas num problema técnico, mas na capacidade de reconhecer e respeitar qualidades presentes na teia da vida que compõe os ecossistemas, transformando-se num questionamento de valores. Acredita-se, conforme já enfatizado por Morgan (1996), que as novas imagens e ideias trazidas por esse estudo possam sensibilizar os gestores para novos tipos de entendimento sobre o processo de gestão sustentável das empresas, criando ações organizacionais mais efetivas e conscientes para o meio ambiente. 


\section{REFERÊNCIAS}

ACKERMAN, R. W. How companies respond to social demands. Harvard Business Review, v.51, n.4, p.88-98, Jul./Aug., 1973.

ALIER, J. M. \& Jusmet, J. R. Economía Ecológica y política ambiental. México: Fondo de Cultura Económica, 2000.

ALIGLERI, L. Responsabilidade social e cultura organizacional: o caso da Ford Brasil. Londrina: Paraná, 2002. Dissertação (Mestrado em Administração). Mestrado Consorciado Universidade Estadual de Londrina e Universidade Estadual de Maringá.

. et al. Gestão socioambiental: responsabilidade e sustentabilidade do negócio. São

Paulo: Atlas, 2009.

ALMEIDA, F. Os desafios da sustentabilidade. Rio de Janeiro: Elsevier, 2007.

AMAZONAS, M. C. Desenvolvimento Sustentável e a Economia Ecológica. In: NOBRE M.; AMAZONAS, M. de C. (Org.). Desenvolvimento sustentável: a institucionalização de um conceito. Brasília: Edições IBAMA, 2002. p. 193-278.

ANDRADE, D. C.; ROMEIRO, A. R. Capital Natural, serviços ecossistêmicos e sistema econômico: rumo a uma economia dos ecossistemas. In: ENCONTRO NACIONAL DE ECONOMIA, ANPEC, 37, 2009, Foz do Iguaçu-PR. Anais... Foz do Iguaçu: ANPEC, 2009. CD-ROM.

ASHLEY, P. A. MACEDO-SOARES, D. L. Um Modelo Conceitual para à Incorporação da Responsabilidade Social à Governança das Relações Negócio-Sociedade. In: ENCONTRO DA ANPAD, ANPAD, 25, 2001, Campinas, Anais..., Rio de Janeiro: Associação Nacional dos Programas de Pós-graduação em Administração, set. 2001. p 1-15. CD-ROM.

(Org.). Ética e responsabilidade social nos negócios. São Paulo: Saraiva,

2002.

AVELINE, C. C. A vida secreta da natureza. Blumenau: Edifurb, 1999.

BAKKER, F, et al. A bibliometric analysis of 30 years or research and theory on corporate social responsibility and Corporate Social Performance. Business and Society, v. 44, n. 3, p. 283-317, Sept., 2005.

BANKS, M.; VERA, D. Towards a typology of stakeholder management. In: ANNUAL MEETING ACADEMY OF MANAGEMENT CONFERENCE, 2007, Philadelphia, PA. Anais ... , 2007. Philadelphia, 2007, p. 1-6, CD-ROM.

BARBIERI, J. C. Gestão ambiental empresarial: conceitos, modelos e instrumentos. São Paulo: Saraiva, 2007. 
; CAJAZEIRA, J. E. R. Responsabilidade social empresarial e empresa sustentável: da teoria à prática. São Paulo: Saraiva, 2009.

BATESON, G. Steps to an ecology of mind. New York: Ballantine, 1972.

BAUMGÄRTNER, S.; QUAAS, M. F. What is Sustainability Economics? Ecological Economics, Boston University, v. 69, n. 3, p. 445-450, Jan., 2010

BELLO, C. V. V. Zeri: uma proposta para o desenvolvimento sustentável com enfoque na qualidade ambiental voltada ao setor industrial. Florianópolis, 1998. Tese (Doutorado em Engenharia de Produção). Programa de Pós-Graduação em Engenharia de Produção da Universidade Federal de Santa Catarina.

BERTAlAnFFY, L. V. Teoria geral dos sistemas. 2 ed. Petrópolis: Vozes, 1975. Título original: General system theory. George Braziller, 1968.

BOEIRA, S. L. Ecologia política: Guerreiro Ramos e Fritjof Capra. Ambiente e sociedade. Campinas, ano 5, n. 10, p. 85-105, Jan./Jun. 2002. Disponível em: <http://www.scielo.br/pdf/asoc/n10/16887.pdf>. Acesso em: 20/03/2010.

BORGER, F. G. Responsabilidade social: efeitos da atuação social na dinâmica empresarial. São Paulo, 2001. Tese (Doutorado em Administração). Programa de Pós-Graduação em Administração, Departamento de Administração, Faculdade de Economia, Administração e Contabilidade da Universidade de São Paulo.

; KRUGLIANSKAS, I. Corporate social responsibility and environmental and technological innovation performance: case studies of brazilian companies. In: INTERNATIONAL CONFERENCE ON TECHNOLOGY POLICY AND INNOVATION, 6, Kansai 2002, Anais..., Kyoto, Japan, 2002. p. 1-13. CD-ROM.

Considerações Teóricas Sobre Gestão da Responsabilidade Social Empresarial.

Texto para aula. Instituto Ethos, março, 2004. Disponível em: <http://www.ethos.org.br/_Uniethos/Documents/aula_Fernanda_03_04.pdf >. Acesso em: 03/07/2008.

BOULDING, K. E. The economics of the coming spaceship Earth. In: JARETT, H. (Org.) Environmental quality in a growing economy. Resources for the Future/Johns Hopkins University Press, Baltimore, 1966.

BRAND, F., Critical natural capital revisited: ecological resilience and sustainable development. Ecological Economics, Boston University, v. 68, n. 3, p. 605-612, Jan., 2009.

BRUNDTLAND, G. H. Nosso futuro comum. Rio de Janeiro: FGV, 1988. Título original: Our common future. New York: Oxford University Press, 1987.

BRÜSEKE, F. J. Problema do Desenvolvimento Sustentável In: CAVALCANTI,C. (Org.). Desenvolvimento e natureza: estudos para uma sociedade sustentável. São Paulo: Cortez, 2003. 
CAMPANHOL, E. M.; BREDA, F. A. Responsabilidade social: entre o assistencialismo e a moderna gestão corporativa. In: ENCONTRO DA ANPAD, ANPAD, 29, 2005, Brasília, Anais..., Rio de Janeiro: Associação Nacional dos Programas de Pós-graduação em Administração, set. 2005. p 1-16. CD-ROM.

CAMPOS, C. 0 pressuposto da ética na preservação do meio ambiente: breve história sobre origens e conceitos do movimento ambientalista. ALCEU, PUC-Rio, v. 8, n.16, p. 19-51. Jan./Jun., 2008. Disponível em: < http://publique.rdc.pucrio.br/revistaalceu/media/alceu_n16_Campos.pdf>. Acesso em: 04/04/2010.

CAPRA. F. O ponto de mutação: a ciência a sociedade e a cultura emergente. São Paulo: Cultrix, 1987. Título original: The turning point, 1982.

. A teia da vida: uma nova compreensão científica dos sistemas vivos. São Paulo: Cultrix, 1997. Título original: The web of life, 1996.

As conexões ocultas: ciência para uma vida sustentável. São Paulo: Cultrix, 2002. Título original: The hidden connections, 2002.

Falando a linguagem da natureza: princípios da sustentabilidade. In: STONE, M. K.; BARLOW, Z (Orgs.). Alfabetização ecológica. São Paulo: Cultrix, 2006. Título original: Ecologial Literacy. Collective Heritage Institute, 2005.

CARRIERI, A. P. et al. O tema da proteção ambiental Incorporado nos discursos da responsabilidade social corporativa. Revista de Administração Contemporânea, ANPAD, Curitiba, v. 13, n. 1, p. 1-16, Jan./Mar. 2009.

CARROLL, A. B. Three dimensional conceptual model $f$ corporate performance. Academy of Management Review, v. 4, n. 4, p. 497-505, 1979.

; HOY, F. Integrating corporate social policy into strategic management. Journal of Business Strategic, v. 4, n.3, p. 48-57, winter, 1984.

The pyramid of corporate social responsibility: toward the moral management of organizational stakeholders. Business Horizons, v. 34, n. 4, p. 39-48, Jul/Aug, 1991.

.; BUCHHOLTZ, A. Business and society: ethics and stakeholder management. 4 th. Thomson Learning: South-Western College Publishing, 2000.

CARVALHO, M. A et al. Complexidade e sustentabilidade gerando o ecodesign nas organizações sociais. In: SAFETY HEALTH AND ENVIRONMENTAL WORLD CONGRESS, 7, 2007, Santos - SP. Anais ..., Santos: UNISANTOS, 2007. Disponível em:<http://www.buscalegis.ufsc.br/revistas/index.php/buscalegis/article/viewFile/6519/6086> Acesso em: 02/04/2010.

CASTELLS, M. Para além da caridade: responsabilidade social no interesse da empresa na nova economia. In: CORTINA, A (Org.). Construir confiança. São Paulo: Loyola, 2007. Título original: Construir Confianza. Trota, 2003. 
CAVALCANTI, C. Breve introdução à economia da sustentabilidade. In: (Org). Desenvolvimento e natureza: estudos para uma sociedade sustentável. São Paulo: Cortez, 2003.

CECHIN, A.; VEIGA, J. E. O fundamento central da economia ecológica. In: MAY, P. (Org.) Economia do meio ambiente: teoria e prática, $2^{\underline{a}}$ ed, Rio de Janeiro: Elsevier/Campus, 2010. p. 33-48.

CIPOLA, F. C. et al. Avaliação do desempenho social: uma discussão apoiada em análise envoltória de dados (DEA) em empresas siderúrgicas no Brasil. In: CONGRESSO USP DE CONTROLADORIA E CONTABILIDADE, 8, 2008, São Paulo. Anais ..., São Paulo: USP, 2008. Disponível em: <http://www.congressousp.fipecafi.org/artigos82008/229.pdf>. Acesso em: 03/11/2010.

CLARO, P. B. O; et al. Entendendo o conceito e sustentabilidade nas organizações. Revista de Administração, Universidade de São Paulo, São Paulo, v. 43, n. 4, p. 289-300, Dez., 2008 .

COELHO, A. C. D.; CORRAR, L. J. Apropriação dos resultados corporativos aos fatores econômicos nas empresas de capital aberto e de capital fechado no Brasil: evidências de atributos discriminatórios. In: CONGRESSO USP DE CONTROLADORIA E CONTABILIDADE, 5, 2005, São Paulo. Anais ..., São Paulo: USP, 2005. Disponível em: < http://www.congressousp.fipecafi.org/artigos52005/22.pdf >. Acesso em: 12/07/2010.

CONSTANZA, R. (Org.) Ecological Economics: the science and management of sustainability. New York: Columbia University Press, 1991. Disponível em:< http://www.powells.com/biblio/62-9780231075633-2>. Acesso em: 02/04/2010.

COOPER, D. R.; SCHINDLER, P. S. Métodos de pesquisa em administração. 7 ed. Porto Alegre: Bookman, 2003. Título original: Business research methods. McGraw-Hill, 2001.

CORTINA, A. NAVARRO. E. M. Ética. São Paulo: Loyola, 2005.

COVEY, S. R. The seven habits of highly effetive people. New York: Simon and Schuster, 1989.

D’AMBRÓSIO. A ciência moderna em transição conceitual. In: BRANDÃO, M. S.; CREMA, R. (Orgs). O novo paradigma holístico. São Paulo: Summus, 1991.

DALY, H. E.; TOWNSEND, K. (Orgs). Valuing the earth: economics, ecology, ethics. ethics. Massachusetts: The MIT Press Cambridge, 1993.

The steady-state sconomy: toward a political economy of biophysical equilibrium and moral growth. In: DALY, H. E. (Org.). Economics, ecology, ethics: essays toward a steady-state economy, San Francisco: Freeman, 1980.

Beyond growth. San Francisco: Freeman, 1997.

DAVIS, K. The case for and against business assumption of social responsibilities. Academy of Management Journal, v. 16, n. 2, p. 312-322, Jun., 1973 
DENARDIN, V.; SULZBACH, M. Capital Natural na Perspectiva da Economia. In: ENCONTRO DA ASSOCIAÇÃO NACIONAL DE PÓS-GRADUAÇÃO EM PESQUISA EM AMBIENTE E SOCIEDADE, 1, 2002, Indaiatuba. Anais ..., São Paulo: ANPPAS, 2002. Disponível em: < http://www.anppas.org.br/encontro_anual/encontro1/gt/recursos_hidricos/ >. Acesso em: 04/05/2010.

DEVALL, B. The deep, long-range ecology movement. Ethics e The Environment, Indiana University Press, v. 6, n. 1, p. 18-41, spring, 2001. Disponível em: < https://muse.jhu.edu/journals/ethics_and_the_environment/v006/6.1devall.pdf $>$. Acesso em: 03/02/2010.

DONALDSON T., PRESTON, L. The stakeholder theory of the corporation: concepts, evidence and implications. Academy of Management Review, Mississippi State, v.20, n. 1, p.65-91, Jan., 1995.

DRUCKER, P. Administrando em tempos de grandes mudanças. São Paulo: Pioneira, 1996. Título original: Managing in a Time of Great Change, 1995.

Sociedade pós-capitalista. São Paulo: Pioneira, 1995. Título original: The PostCapitalist Society, 1993.

EELLS, R.; WALTON, C. Conceptual foundations of business. Homewood: Richard D. Irwin, 1974.

EGRI, C.P.; PINFIELD, L.T. As organizações e a biosfera: ecologia e meio ambiente. In: CLEGG et al. Handbook de estudos organizacionais. São Paulo: Atlas, 1998.

ELKINGTON, J. Canibais com garfo e faca. São Paulo: Makron, 2001. Título original: Cannibals with forks. Capstone Publishing, 2000.

ERICKSON, K. E. Ciência para o desenvolvimento sustentável. In: CAVALCANTI, C. (Org.). Meio ambiente, desenvolvimento sustentável e políticas públicas. São Paulo: Cortez; Recife: Fundação Joaquim Nabuco, 2002.

FERRY, L. A nova ordem ecológica: a árvore, o animal e o homem. São Paulo: Ensaio, 1994. Título original: Le nouvel ordre écologique. Paris: Éditions Grasset e Fasquelle, 1992.

FIGUEIRA, C. V. Modelos de regressão logística. Porto Alegre, 2006. Dissertação (Mestrado em Matemática). Programa de Pós-Graduação em Matemática, Instituto de Matemática, Universidade Federal do Rio Grande do Sul.

FIGUEROA, J. R. Valoración de la biodiversidad: perspectiva de la economía ambiental y la economia ecológica. Interciencia, Caracas, v. 30, n. 2, p.103-107, Fev. 2005. Disponível em:<http://www.scielo.org.ve/ >. Acesso em: 01/04/2010.

FREEMAN E. Strategic management: stakeholder approach. London: Pitman Publishing, 1984.

FREIRE, R. et al. Articulação Teórica entre responsabilidade social corporativa e vantagem competitiva. In: ENCONTRO DA ANPAD, ANPAD, 33, 2009, São Paulo-SP, Anais..., Rio 
de Janeiro: Associação Nacional dos Programas de Pós-graduação em Administração, set. 2009. CD-ROM.

FROOMAN, J. Stakeholder influence strategies. The Academy of Management Review, Briarcliff Manor, v. 24, n. 2, p. 191-205, Apr 1999.

FURTADO, J. S. O caminho da sustentabilidade econômica-ambiental-social: guia para organizações. Agosto, 2004. Disponível em: http://intertox.com.br/index.php?option=com_docman\&task=cat_view\&gid=71\&Itemid=98>. Acesso em: 13/01/2011.

Gestão com responsabilidade socioambiental. Março, 2003. Disponível em: < http://intertox.com.br/index.php?option=com_docman\&task=cat_view\&gid=71\&Itemid=98>. Acesso em: 10/09/2010.

GARRIGA, E. MELÉ, D. Corporate social responsibility: mapping the territory. Journal of Business Ethics, v. 53, n. 1, p. 51-71, Dec., 2004.

GEORGESCU-ROEGEN, N. The entropy law and the economic process. Cambridge: Harvard University Press, 1971.

GIOVANNINI, F.; KRUGLIANSKAS, I. Organização eficaz. São Paulo: Nobel, 2004.

. A influência dos padrões para sistemas de gestão no desempenho das empresas. São Paulo, 2008. Tese (Doutorado em Administração). Programa de Pós-Graduação em Administração, Departamento de Administração, Faculdade de Economia, Administração e Contabilidade da Universidade de São Paulo.

GLOBAL REPORTING INITIATIVE - GRI. Indicador protocols: economic, environment, human rights, labor, product responsibility, society. Amsterdam, 2006 Disponível em:< http://www.globalreporting.org/ReportingFramework/ReportingFrameworkDownloads/>.

Acesso em: 12/05/2008.

GRAYSON, D.; HODGES, A. Compromisso social e gestão empresarial. São Paulo: Publifolha, 2002. Título original: Everybody's Business. Londres: Dorling Kindersley, 2001.

HAIR, J. F. et al. Multivariate data analysis. $5^{\text {th }}$ ed. New Jersey: Prentice Hall, 1998.

et al. Fundamentos de métodos de pesquisa em administração. Porto Alegre: Bookman, 2005. Título original: Research methods for business, 1999.

HALl, C. S.; LINDZEY, G. Teorias da Personalidade. São Paulo: Edusp, 1973. Título original: Theories of personality, 1970.

HART, S. L. e MILSTEIN, Mark. Criando Valor Sustentável. RAE Executivo, FGV, São Paulo, v. 3, n. 2, p.65-79, Maio/Jul., 2004.

.O capitalismo na encruzilhada. Porto Alegre: Bookman, 2006. Título original: Capitalism at the crossroads. Prentice Hall, 2006. 
HAWKEN, P. The ecology of commerce: a declaration of sustentabiblity. New York: HarperBusiness, 1993.

et al. Capitalismo natural: criando a próxima revolução industrial. São Paulo, Editora Cultrix, 2000. Título original: Natural capitalism, 1999.

HITT, M. A. et al. Administração estratégica. São Paulo: Thompson, 2002 Título original: Strategic management, 1999.

HOURNEAUX, F. Relações entre as partes interessadadas (stakeholders) e os sistemas de mensuração do desempenho organizacional. São Paulo, 2010. Tese (Doutorado em Administração). Programa de Pós-Graduação em Administração, Departamento de Administração, Faculdade de Economia, Administração e Contabilidade da Universidade de São Paulo.

HRDLICKA, H. As boas práticas de gestão ambiental e a influência no desempenho exportador: um estudo sobre as grandes empresas exportadoras brasileiras. São Paulo, 2009. Tese (Doutorado em Administração). Programa de Pós-Graduação em Administração, Departamento de Administração, Faculdade de Economia, Administração e Contabilidade da Universidade de São Paulo.

IBGC. Guia de sustentabilidade para as empresas. Instituto Brasileiro de Governança Corporativa, séria Cadernos de Governança Corporativa, n. 4. São Paulo: 2007.

INMAN, R. A. Implications of environmental management for operations management. Production Planning e Control, v. 13, n. 1, p. 47-55, 2002.

INSTITUTO ETHOS. Critérios essenciais de responsabilidade social empresarial e seus mecanismos de indução no Brasil. São Paulo: Instituto Ethos, 2007.

Indicadores Ethos de Responsabilidade Social Empresarial 2008. São Paulo: Instituto Ethos, 2008.

O que é RSE. Disponível em:

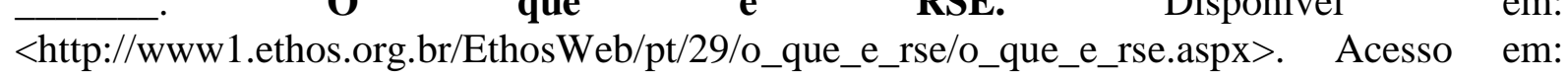
$11 / 01 / 2010$.

ISHIKAWA, N. I. Uso de transformações em modelos de regressão logística. São Paulo, 2007. Dissertação (Mestrado em Ciências). Instituto de Matemática e Estatística, Universidade de São Paulo.

IPCC. Climate change 2007: Impacts, Adaptation and Vulnerability. Summary for Policymakers. Contribution of Working Group II to the Fourth Assessment Report of the Intergovernmental Panel on Climate Change, 2007. Disponível em:<http://www.ipcc.ch/ipccreports/ar4-wg2.htm>. Acesso em: 01/09/2007.

ISO. ISO 26000:2010 - Guidance on social responsibility. Final draft international standard. International Organization for Standardization, 2010. Disponível em: <http://www.psqca.com.pk/News\%20Bar/attention\%20ISO\%2026000/ISO_FDIS_26000_(E) .pdf>. Acesso em: 25/09/2010. 
JENNINGS, P.D.; ZANDBERGEN, P. Ecologically sustainable organizations: an institutional approach. Academy of Management Review, v. 20, n. 4, p. 1015-1052, Oct., 1995.

JOHNSON, H. L. Business in contemporary society: framework and issues. Belmont: Wadsworth, 1971.

JONAS, H. O princípio da responsabilidade: ensaio de uma ética para a civilização tecnológica. Rio de Janeiro: Contraponto, 2006. Título original: Das Prinzip Verantwortung. Versuch einer Ethik für die technologische Zivilisation. Frankfurt : Suhrkamp., 1979.

KERLINGER, F. N. Metodologia de pesquisa em ciências sociais: um tratamento conceitual. São Paulo: EPU, 1980.

KOTLER, P. et al. Marketing 3.0: as forças que estão definindo o novo marketing centrado no ser humano. Rio de Janeiro: Elsevier, 2010.

KREITLON, M. P.; QUINTELlA, R. H. Práticas de accountability ética e social: as estratégias de legitimação de empresas brasileiras nas relações com os stakeholders. In: ENCONTRO DA ANPAD, 25, 2001, Campinas, Anais..., Rio de Janeiro: Associação Nacional dos Programas de Pós-Graduação em Administração, set. 2001. p 1-15. CD-ROM.

LASZLO, E. Macrotransição: o desafio para o terceiro milênio. São Paulo: Axis Mundi, Willis Harmam House, 2001. Título original: Navigating the macroshift: our evolution in our hands. Axis Mundi, 2001.

LAYRARGUES, P. P. Determinismo biológico: o desafio da alfabetização ecológica na concepção de Capra. In: ENCONTRO DE PESQUISA EM EDUCAÇÃO AMBIENTAL, 2, 2003, Rio Claro. Anais .... Rio Claro: UFSCar. 2003. Disponível em: <http://uniohm.multiply.com/journal/item/37>. Acesso em: 02/04/2010.

LEAL, S. Corporate social responsibility as a tool for competitiveness: an empirical study. In: CONFERÊNCIA LUSO-ESPANHOLA DE GESTÃO E CONTABILIDADE AMBIENTAL, 1, 2005. ESTG-IPL. Anais ... Leiria, 2005. Disponível em: <http://docentes.esgs.pt/aep/Investigacao_ficheiros/RespSocial2.pdf $>$ Acesso em: 22/05/2010.

LEOPOLD, A. The land ethic In: A Sand County Almanac. New York: Oxford University Press, 1949. p. 201-226.

LOUETTE, A (Org.). Compêndio para a sustentabilidade: ferramentas de gestão de responsabilidade socioambiental. São Paulo: Antakarana Cultura Arte e Ciência, 2007.

LOVELOCK, J. E. Gaia: a new look at life on earth. New York: Oxford University Press, 1979.

LOYOLA, R. A econômica ambiental e a economia ecológica: uma discussão teórica. In: ENCONTRO DA SOCIEDADE BRASILEIRA DE ECONOMIA ECOLÓGICA, ECOECO, 2, 1997, São Paulo. Anais .... São Paulo, 1997. Disponível em: 
<https://www.ecoeco.org.br/conteudo/publicacoes/encontros/ii_en/mesa2/4.pdf $>$. Acesso em: 20/04/2010.

MACHADO FILHO, C. A. P.; ZYLBERSZTAJN, D. A empresa socialmente responsável: o debate e as implicações. Revista de Administração, Universidade de São Paulo, São Paulo, v. 39, n. 03, p. 242-254, 2004.

Responsabilidade social e governança. São Paulo; Thompson-Pioneira, 2006.

MANCINI, S. Gestão com responsabilidade socioambiental. São Paulo, 2008. Tese (Doutorado em Ciência Ambiental) - Interunidades em Ciência Ambiental. Universidade de São Paulo.

MATURANA, H.; VARELA, F. J. Autopoiesis and cognition. Dordrecht: D. Reidel: 1980.

; VARELA, F. J. A árvore do conhecimento: as bases biológicas da compreensão humana. São Paulo: Palas Athena, 2001. Título original: El árbol del conocimiento, 1984.

MENDONÇA, J. R.; GONÇALVES, J. C. S. Responsabilidade Social nas Empresas: uma questão de imagem ou de substância? . In: ENCONTRO DA ANPAD, 26, 2002, Salvador, Anais..., Rio de Janeiro: Associação Nacional dos Programas de Pós-Graduação em Administração, set. 2002. p 1-15. CD-ROM.

MENDONÇA, L. R. Desenvolvimento e sustentabilidade: um estudo de alianças estratégicas intersetoriais no empreendedorismo social. São Paulo, 2007. Tese (Doutorado em Administração). Programa de Pós-Graduação em Administração, Departamento de Administração, Faculdade de Economia, Administração e Contabilidade da Universidade de São Paulo.

MEBRATU, D. Sustainability and sustainable development: historical and conceptual review. Environmental Impact Assessment Review, New York, v. 18, n. 6, p. 493-520, 1998.

MILLENNIUM ECOSYSTEM ASSESSMENT - MEA. Ecosystem and human well-being: a framework for assessment. Washington, DC: Island Press, 2003.

MITCHELL, R. K. et al. Toward a theory of stakeholder identification and salience: defining the principle of who and what really counts. Academy of Management Review, v. 22, n. 4, p. 853-886, 1997.

MORGAN, G. Imagens da organização. São Paulo: Atlas, 1996. Título original: Images of organization. California: Sage Publications, 1986.

MUELLER, C. C. O debate dos economistas sobre a sustentabilidade: uma avaliação sob a ótica da análise do processo produtivo de Georgescu-Roegen. Estudos Econômicos. Instituto de Pesquisas Econômicas, São Paulo, v. 35, n. 4, p. 687-713, 2005.

Os economistas e as relações entre o sistema econômico e o meio ambiente. Brasília: Editora UnB, 2007. 
NAESS, A. The shallow and the deep, long-range ecology movements: a summary. Inquiry, v. 1, n.16, p. 95-100, 1973.

NASCIMENTO, L. F. et al. Gestão socioambiental estratégica. Porto Alegre: Bookman, 2008.

NORTON, B. G. Evaluating ecosystem states: two competing paradigms. Ecological Economics, v. 14, n. 2, p. 113-127, Aug., 1995.

O'CONNOR, M. Natural capital. Policy Research Brief, n. 3, Cambridge Research for the Environment, 2000. Disponível em: <http://www.clivespash.org/eve/PRB3-edu.pdf>.Acesso em: 02/03/2010.

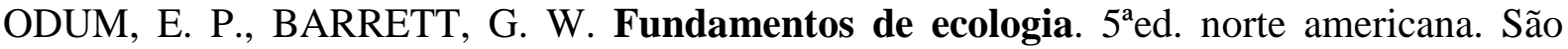
Paulo: Cengage Learning, 2008. Título original: Fundamentals of ecology, 2007.

; ODUM, H. T. A prosperous way down: principles and policies, with Elisabeth C. Odum, University Press of Colorado, 2001.

Ecology: a bridge between science and society. 3rd .Sinauer Associates, 1997.

ONUSIC, L. M. A qualidade de serviços de ensino superior: o caso de uma instituição de ensino. São Paulo, 2009. Tese (Doutorado em Administração). Programa de Pós-Graduação em Administração, Departamento de Administração, Faculdade de Economia, Administração e Contabilidade da Universidade de São Paulo.

PACE, E. S. U. et al. Indicadores de Desempenho como Direcionadores de Valor. Revista de Administração Contemporânea, ANPAD, Curitiba, v. 7, n. 1, p. 37-65, Jan./Mar. 2003.

PASSADOR, C et al. Apontamentos sobre a responsabilidade social no ENANPAD: construção de um conceito. In: ENCONTRO DA ANPAD, 29, 2005, Campinas, Anais..., Rio de Janeiro: Associação Nacional dos Programas de Pós-Graduação em Administração, set. 2005. p 1-16. CD-ROM.

PAVA, M. L. Getting to the bottom of triple bottom line. Business Ethics Quarterly. Chicago, v. 17, n. 1, p. 105, Jan., 2007.

PEARCE, D. W.; TURNER, K. R. Economics of natural resources and the environment. Baltimore: The Johns Hophins University Press, 1990.

PINHEIRO, P. F. Implantação da responsabilidade social empresarial na gestão de fornecedores da construção civil: análise do programa TEAR. São Paulo, 2009. Dissertação (Mestrado em Engenharia). Departamento de Engenharia de Construção Civil, Escola Politécnica da Universidade de São Paulo.

PORTER, M. E.; KRAMER, M. R. Strategy and society: the link between competitive advantage and corporate social responsibility. Harvard Business Review, v. 84, n. 12, p.7692, Dec., 2006. 
; LINDE, C. Verde e competitivo: acabando com o impasse. In: PORTER, M. E. Competição on competition: estratégias competitivas essenciais. RJ: Campus, 1999. p. 371397.

PRESTON, L.E.; POST, J.E. Private management and public policy. Califórnia Management Review. Berkeley, v. 23, n. 3, p.56-62, spring. 1975.

RIBEIRO, F. M.; KRUGLIANSKAS, I. . Políticas Públicas Ambientais e Indução da Melhoria de Desempenho: uma Revisão Inicial. In: INTERNATIONAL WORKSHOP ADVANCES IN CLEANER PRODUCTION, 2, 2009, São Paulo. Anais .... São Paulo: UNIP, $2009 . \quad$ Disponível em:< http://www.advancesincleanerproduction.net/second/files/sessoes/5a/4/F.\%20M.\%20Ribeiro \%20-\%20Resumo\%20Exp.pdf>. Acesso em: 11/10/2010.

ROCHLIN, S. Responsabilidade empresarial no DNA da empresa. Harvard Business Review Brasil, vol. 83, n. 8, p.19-25, Ago., 2005.

ROHDE, G. M. Mudanças de paradigma e desenvolvimento sustentado. In: CAVALCANTI,C (Org.). Desenvolvimento e natureza: estudos para uma sociedade sustentável. São Paulo: Cortez, 2003.

ROHRICH, S. S.; CUNHA, J. C. A proposição de uma taxonomia para análise da gestão ambiental no Brasil. Revista de Administração Contemporânea, Curitiba, v. 8, n. 4, p. 8197, Out./Dez. 2004.

ROMEIRO, A. R. Economia ou economia política da sustentabilidade. In: MAY, P. H et al. (Orgs.). Economia do meio ambiente: teoria e prática. Rio de Janeiro: Campus, 2003. p. 129.

SACHS, I. Rumo a ecossocioeconomia. Rio de Janeiro: Cortez 2007.

SAMPIERI, R. H. et al. Metodologia de pesquisa. 3 ed. São Paulo: McGraw-Hill, 2006. Título original: Metodología de la investigación, 2003.

SAUNDERS, M. et al. Research methods for business students. 4 th. Harlow: Pearson Education, 2007.

SAVAGE, G. T. et al. Strategies for assessing and managing organizational stakeholders. Academy of Management Executive, v. 5, n. 2, p-61-75, 1991.

SAVITZ, S. A empresa sustentável. Rio de Janeiro: Elsevier, 2007. Título original: The triple bottom line. Jossey-Bass, 2006.

SCHARF, R. Manual de negócios sustentáveis: como aliar rentabilidade e meio ambiente. São Paulo: Amigos da Terra, 2004.

SCHWARZ, M. S., CARROLL, A. B. Corporate social responsibility: a three-domain approach. Business Ethics Quarterly, Chicago, v. 13, n. 4, Oct., 2003. 
SETHI, S. P. Dimensions of corporate social performance: an analytical framework. California Management Review, v. 17, n. 3, p. 58-64, Spring, 1975.

SHELDRAKE, R. A new science of life. Los Angeles: Tarcher, 1981.

SILVA, S. L. Modelo de gestão da performance social orientada pelos stakeholders. Florianópolis, 2006. Tese (Doutorado em Engenharia de Produção). Programa de PósGraduação em Engenharia de Produção da Universidade Federal de Santa Catarina.

SOARES, T. M. Utilização da teoria da resposta ao item na produção de indicadores sócioeconômicos. Pesquisa operacional, Sociedade Brasileira de Pesquisa Operacional, v. 25, n. 1, p. 83-112, Jan-Abr., 2005. Disponível em: < http://www.scribd.com/doc/17038420/Teoriada-Respota-ao-Item-TRI-Tufi-Soares $>$. Acesso em: 13/03/2010.

SOLOW, R. Growth theory: an exposition. Oxford University Press, 2000.

SOUZA, R. S. Entendendo a Questão Ambiental. Santa Cruz do Sul: EDUNISC, 2000.

SOUZA, M. J.; MARCON, R. A responsabilidade social das empresas para com consumidores, acionistas e sociedade. In: ENCONTRO NACIONAL DE ESTUDOS ORGANIZACIONAIS, 2, 2002, Recife. Anais..., Recife: Observatório da Realidade Organizacional: UFPE: ANPAD, maio 2002.

SROUR, R. H. Ética empresarial: posturas responsáveis nos negócios, na política e nas relações pessoais. São Paulo: Campus, 2000.

STEINER, G. A. Business and society. New York: Random House, 1971.

STERN, N. Stern Review on the Economics of Climate Change. HM Treasury, London: $2006 . \quad$ Disponível em:<www.hmtreasury.gov.uk/independent_reviews/stern_review_economics_climate_change $>$. Acesso em: 02/08/2007.

STEURER, R. et al. Corporations, stakeholders and sustainable development I: a theoretical exploration of business-society relations. Journal of Business Ethics, Netherlands, v. 61, $\mathrm{n}$. 3, p. 263-281, Oct., 2005.

STONER, J. A. F.; FREEMAN, R. E. Administração. 5 ed. Rio de Janeiro: LTC, 1999. Título original: Management. Prentice-Hall, 1982.

TACHIZAWA, T. Gestão ambiental e responsabilidade social corporativa. 2 ed. São Paulo: Atlas, 2004.

TAMBELLINI, A. T. Sustentabilidade e sustenibilidade: um debate sobre a concepção de uma sociedade sustentável. Ciência \& Saúde Coletiva, v. 14, n. 6, p. 1977-1982, Dez., 2009.

TOMEI, P. Responsabilidade social de empresas: análise qualitativa da opinião do empresariado nacional. Revista de Administração de Empresas, Rio de Janeiro, v.24. n. 4, p. 189-202, Out./Dez., 1984. 
UNIVERSIDADE DE SÃO PAULO. Manual para formatação e edição de dissertações e teses. Faculdade de Economia, Administração e Contabilidade, Comissão de Pós-Graduação, 2008.

VEIGA, J. E. Desenvolvimento sustentável: alternativas e impasses. In: KEINERT, T. M. M. (Org.). Organizações sustentáveis: utopias e inovações. São Paulo: Annablume; Belo Horizonte: Fapemig, 2007. p. 21-41.

Desenvolvimento sustentável: o desafio do século XXI. 3 ed. São Paulo: Garamond, 2008.

; CECHIN, A. Introdução. In: VEIGA, J. E. (Org.). Economia socioambiental. São Paulo: SENAC, 2009.

VELOSO, L. H. M. Ética, valores e cultura: especificidades do conceito de responsabilidade social corporativa. In: ASHLEY, P. A. Ética e responsabilidade social nos negócios. São Paulo: Saraiva, 2002.

VIEIRA, P. F. Ecodesenvolvimento: do conceito à ação. In: SACHS, I. Rumo a ecossocioeconomia. Rio de Janeiro: Cortez 2007. p. 9-31.

WADDOCK, S. Parallel universes: companies, academics, and the progress of corporate citizenship. Business and Society Review, Bentley College, v. 4, n. 1, p. 5-42, March, 2004.

WALKER, S.; MARR, J. W. Stakeholder power. Cambridge, Massachusetts: Perseus Publishing, 2001.

WARTICK, S. L.; COCHRAN, P. L. The evolution of the corporate social performance model. Academy of Management Review, v. 10, n. 4, p. 758-769, Oct., 1985.

WELZEL, E. Tipologia das atividades de responsabilidade social corporativa na esfera internacional: (in)dependência do contexto cultural ? In: SIMPOSIO DE ADMINISTRAÇÃO, PRODUÇÃO, LOGÍSTICA E OPERAÇÕES INTERNACIONAIS, SIMPOI, 12, 2009, São Paulo, Anais..., São Paulo: FGV, ago. 2009. p 1-17. Disponível em: < http://www.simpoi.fgvsp.br/arquivo/2009/artigos/E2009_T00465_PCN04234.pdf>. Acesso em: 10/01/2010.

WERLANG, P. O papel do gestor de recursos humanos na construção da responsabilidade social empresarial. In: INSTITUTO ETHOS. Responsabilidade Social das Empresas: a contribuição das universidades, v. 2. Prêmio Ethos Valor 2002. São Paulo: Peirópolis: Instituto Ethos, 2003.

WILSON, E. O. Biophilia. Cambridge: Harvard University Press, 1984. Disponível em: < http://books.google.com.br/books>. Acesso em: 10/12/2010.

WOOD JR, T.; ZUFFO, P. K. Supply chain management: uma abordagem estratégica para a logística. In: ENCONTRO DA ANPAD, 21, 1997, Rio das Pedras, Anais..., Rio de Janeiro: Associação Nacional dos Programas de Pós-Graduação em Administração, set. 1997. p 1-15. CD-ROM. 
WOOD, D. J. Corporate social performance revisited. Academy of Management Review, v.16, n.4, p. 691-718, Oct., 1991.

ZACCARELli, S. B. Ecologia de Empresas. Cadernos de Administração, v. 4, n. 2, Faculdade de Economia e Administração da Universidade de São Paulo, Fev., 1971.

et al. A. Ecologia de Empresas. São Paulo: Ed. Atlas, 1980.

ZADEK, S. The Path to Corporate Responsibility. Harvard Business Review, v. 82, n. 12, Dec., 2004.

Balancing performance, ethics, and accountability. Journal of Business Ethics, v. 17, n. 13, p. 1421-1441. Oct., 1998. 


\section{APENDICES}

Apêndice A - Carta de Solicitação de Banco de Dados

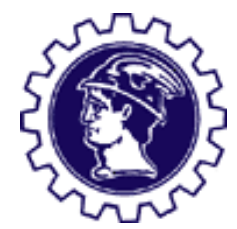

UNIVERSIDADE DE SÃO PAULO

FACULDADE DE ECONOMIA, ADMINISTRAÇÃO E CONTABILIDADE

São Paulo, 15 de janeiro de 2010.

\section{Ao Instituto Ethos de Empresas e Responsabilidade Social A/C Srª Ana Lucia de Melo Custódio}

Prezada Senhora:

A preocupação com uma gestão sustentável é hoje um dos principais desafios do setor empresarial e seu êxito é muito importante para o desempenho competitivo do Brasil num mercado globalizado.

Desta forma, a academia, em diversas áreas do conhecimento, vem buscando indicar e contribuir com perspectivas mais efetivas de gerenciamento das empresas sob o enfoque da sustentabilidade.

Sob a orientação do Prof. Dr. Isak Kruglianskas, professor titular da Universidade de São Paulo, venho desenvolvendo uma pesquisa inédita na forma de um projeto de tese de doutorado vinculado ao Programa de Pós-Graduação em Administração da FEA/USP que busca compreender a relação dos instrumentos de gestão para a sustentabilidade com os princípios ecológicos, conforme proposta de tese anexa.

Desta forma, tendo em vista o trabalho desenvolvido pelo Instituto Ethos sobre a incorporação de práticas socioambientais e o compromisso público das empresas em contribuir para a consolidação de um ambiente de negócios alinhado com o desenvolvimento sustentável, venho solicitar, para realizar com êxito a proposta da tese, o acesso a parte do banco de dados dos Indicadores Ethos 
referente ao ano de 2009. Necessito de informações sobre alguns dos indicadores para verificar a relação entre as variáveis dependentes e independentes propostas na pesquisa.

Para os fins de estudo, não preciso que as empresas sejam identificadas e comprometo-me desde já a guardar sigilo sob toda e qualquer informação que me for disponibilizada. Enfatizo ainda que utilizarei os dados de forma agregada com 0 objetivo estritamente acadêmico.

Espero retribuir com o envio do sumário executivo da pesquisa, em primeira mão e, desde já, convido um membro executivo desse renomado Instituto, com titulação acadêmica compatível, para fazer parte da Comissão Julgadora na Banca de Defesa, conforme previsto no Regimento interno de Pós-Graduação da SP.

Conto com a inestimável e grandiosa colaboração do Instituto Ethos e aguardo resposta até 29 de janeiro de 2010 para que possa iniciar a compilação e análise estatística dos dados. Coloco-me a inteira disposição para os esclarecimentos necessários e aproveito o ensejo para renovar meus votos de estima e consideração.

Cordiais Saudações,

Prof ${ }^{a}$ Lilian Aligleri

Doutoranda em Administração

E-mail: lilian.aligleri@usp.br 